UNIVERSIDADE DE SÃO PAULO

FACULDADE DE FILOSOFIA, LETRAS E CIÊNCIAS HUMANAS

DEPARTAMENTO DE CIÊNCIA POLÍTICA

PROGRAMA DE PÓS-GRADUAÇÃO EM CIÊNCIA POLÍTICA

IAGO CHECO RONDELLO

Neoliberalismo colonial na Palestina ocupada: a assistência financeira internacional no contexto dos "processos de paz"

Versão Corrigida

São Paulo 


\title{
IAGO CHECO RONDELLO
}

Neoliberalismo colonial na Palestina ocupada: a assistência financeira internacional no contexto dos "processos de paz"

\author{
Versão Corrigida
}

Dissertação de Mestrado apresentada ao Programa de Pós-Graduação em Ciência Política do Departamento de Ciência Política da Faculdade de Filosofia, Letras e Ciências Humanas da Universidade de São Paulo, como parte dos requisitos para obtenção do título de Mestre em Ciência Política.

Orientador: Prof. Dr. Jean François Germain Tible

São Paulo 
Autorizo a reprodução e divulgação total ou parcial deste trabalho, por qualquer meio convencional ou eletrônico, para fins de estudo e pesquisa, desde que citada a fonte.

Catalogação na Publicação

Serviço de Biblioteca e Documentação

Faculdade de Filosofia, Letras e Ciências Humanas da Universidade de São Paulo

Rondello, Iago

Neoliberalismo colonial na Palestina ocupada: a assistência financeira internacional no contexto dos "processos de paz" / Iago Rondello; orientador Jean Tible - São Paulo, 2021

$174 \mathrm{f}$.

Dissertação (Mestrado) - Faculdade de Filosofia, Letras e Ciências Humanas da Universidade de São Paulo. Departamento de Ciência Política. Área de concentração: Ciência Política.

1. territórios palestinos ocupados. 2. neoliberalismo. 3. colonialismo. 4. despolitização. 5. "processos de paz". I. Tible, Jean, orient. II. Título. 


\title{
ENTREGA DO EXEMPLAR CORRIGIDO DA DISSERTAÇÃO/TESE
}

\section{Termo de Ciência e Concordância do (a) orientador (a)}

\author{
Nome do (a) aluno (a): Iago Checo Rondello
}

Data da defesa: 28/01/2021

Nome do Prof. (a) orientador (a): Jean François Germain Tible

Nos termos da legislação vigente, declaro ESTAR CIENTE do conteúdo deste EXEMPLAR CORRIGIDO elaborado em atenção às sugestões dos membros da comissão Julgadora na sessão de defesa do trabalho, manifestando-me plenamente favorável ao seu encaminhamento e publicação no Portal Digital de Teses da USP.

São Paulo, 26/03/2021

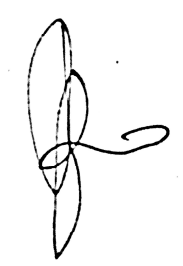


RONDELLO, Iago Checo. Neoliberalismo colonial na Palestina ocupada: a assistência financeira internacional no contexto dos "processos de paz". Dissertação apresentada ao Programa de Pós-Graduação em Ciência Política da Faculdade de Filosofia, Letras e Ciências Humanas da Universidade de São Paulo para obtenção do título de Mestre em Ciência Política.

Aprovada em:

Banca Examinadora:

Prof. Dr. Reginaldo Mattar Nasser

Instituição: PUC-SP

Julgamento: Assinatura:

Profa. Dra. Terra Friedrich Budini Instituição: PUC-SP

Julgamento: Assinatura: 


\section{AGRADECIMENTOS}

Agradeço ao Jean, meu orientador, pela amizade, pelas conversas, pelo acolhimento e por toda a confiança depositada nesse trabalho.

Ao Alexandre Martins, agradeço especialmente a companhia diária, mesmo que à distância. Obrigado por todo o apoio, intelectual e emocional, que você me deu ao longo desses três anos. Sem a sua parceria constante, essa caminhada, já naturalmente solitária, teria sido tão mais angustiante.

Ao Bafti, Ed e Yara, meus companheiros de casa, agradeço a amizade e o carinho dos últimos meses. Vocês têm tornado nosso lar num lugar em que, apesar das adversidades de 2020 e 2021, encontrei a calma que precisava para escrever esse texto.

Ao Davi, agradeço pelo carinho e atenção constantes, pelo esforço diário - tão difícil quanto gratificante - em manter nossa amizade a meio mundo de distância.

Ao Gabriel Siracusa, pela parceria e interlocução nesses últimos três anos, e sobretudo por ter me apoiado e auxiliado nesse tumultuado processo que é iniciar a vida acadêmica e entrar no mundo da pós-graduação.

Ao Augusto Malaman, agradeço a amizade e parceria, na vida acadêmica, mas também para muito além dela.

Às amigas e amigos que fiz na FFIPP, e com quem partilhei a experiência de conhecer a Palestina: Nina, Mari, Anna, Bruno, Helena, Júlia, Arturo, Mona e vários outros. Aprendi e aprendo demais com cada um de vocês.

Agradeço, de forma especial, às palestinas e palestinos que conheci, que me receberam em suas cidades, vilas e casas, e que compartilharam comigo suas realidades e suas lutas. Sobretudo, agradeço ao Yasser.

Ao Val, pelo companheirismo em mais esse caminho. Agradeço a você pela imensa ajuda em pensar comigo as ideias desse trabalho, em acolher minhas reflexões, questioná-las, complementá-las. Obrigado, sobretudo, pela infinita paciência e apoio, nos momentos em que esse trabalho me levou a péssimas versões de mim. Esse texto lhe custou quase tanto quanto a mim, e por isso sou muito grato. 
Aos meus pais, Pedro e Lae, vão os maiores agradecimentos que eu poderia expressar. Agradeço ao meu pai por toda essa amizade, dedicação e confiança; por essa parceria de vida que é minha âncora. À minha mãe e melhor amiga, agradeço o companheirismo e cuidado incansáveis; a atenção, dedicação e preocupação constantes e infinitamente amorosas. Sem vocês dois, eu não poderia ter começado nenhum dos meus caminhos. Obrigado por um amor sem limites. Vocês são os grandes responsáveis por eu ter conseguido finalizar essa pesquisa, e a vocês eu devo tudo.

Agradeço ao Conselho Nacional de Desenvolvimento Científico e Tecnológico (CNPq) o apoio financeiro para a realização dessa pesquisa. 


\section{RESUMO}

RONDELLO, I. C. Neoliberalismo colonial na Palestina ocupada: a assistência financeira internacional no contexto dos "processos de paz". Dissertação (Mestrado). Faculdade de Filosofia, Letras e Ciências Humanas, Universidade de São Paulo. 2021.

Esta dissertação analisa a participação da comunidade de assistência financeira internacional sobretudo do Banco Mundial - nos territórios palestinos ocupados (TPO) da Cisjordânia e da Faixa de Gaza, a partir dos "processos de paz” entre Israel e a Organização para a Libertação da Palestina (OLP). Partindo de um debate teórico sobre o neoliberalismo e uma análise de sua consolidação nos anos 1990, busca-se localizar os "processos de paz", e particularmente a assistência externa impulsionada por eles, como fonte de profundas transformações na economia, política e sociedade palestinas da Cisjordânia e Faixa de Gaza. Argumenta-se que os financiadores internacionais - por meio de projetos de desenvolvimento - incentivaram uma série de transformações locais, em sintonia com as tendências neoliberais globais e com as reestruturações operadas pelos "processos de paz" na matriz de controle colonial de Israel sobre os TPO. Por meio da análise de documentos de projetos realizados pelo Banco Mundial (e, em menor grau, pela USAID), analisa-se como a assistência financeira internacional enquadrou o objetivo de desenvolver os territórios palestinos, e como esse objetivo se traduziu em prescrições de privatização, financeirização, liberalização comercial e boa governança. Argumenta-se que as transformações impulsionadas repõem estruturas de dominação colonial existentes, expressas na contínua soberania israelense sobre os territórios - não questionada pelos "processos de paz". Buscando compreender o neoliberalismo em suas transformações também das esferas sociais e políticas, são analisados projetos voltados a organizações não governamentais palestinas, bem como a mobilização da noção de uma "sociedade civil palestina”. Em particular, argumenta-se que processos de profissionalização e despolitização em chave neoliberal dos modelos de organização social trazem consequências negativas às capacidades de resistência de uma sociedade submetida a uma contínua ocupação colonial. Busca-se observar as articulações do neoliberalismo com estruturas coloniais de dominação, analisando a assistência internacional enquanto agente de transformações neoliberais em contextos coloniais, como aquele dos territórios palestinos ocupados.

Palavras-chave: territórios palestinos ocupados; neoliberalismo; colonialismo; despolitização; "processos de paz". 


\begin{abstract}
RONDELLO, I. C. Colonial neoliberalism in occupied Palestine: international financial assistance in the "peace processes" context. Dissertação (Mestrado). Faculdade de Filosofia, Letras e Ciências Humanas, Universidade de São Paulo. 2021.

This dissertation analyses the participation of the community of international financial assistance - especially the World Bank - in the Occupied Palestinian Territories (OPT), since the "peace processes" between Israel and the Organization for the Liberation of Palestine (OLP). Starting from a theoretical discussion about neoliberalism and from an analysis of its consolidation in the 1990s, we seek to locate the "peace processes", and particularly the external assistance driven by them, as sources of deep changes in the Palestinian economy, politics and society from the West Bank and Gaza Strip. We argue that international financers fostered several local transformations through development projects, in line with global neoliberal trends and with the restructuring operated by the "peace processes" in Israel's colonial matrix of control over the OPT. Through the analysis of documents from projects carried by the World Bank (and, to a lesser extent, the USAID), we analyze how international assistance framed the goal of developing the Palestinian territories, and how this goal was translated into prescriptions of privatization, financialization, commercial liberalization and good governance. We argue that the promoted changes reset existing colonial structures of domination, expressed by the ongoing Israeli sovereignty over the territories - not questioned by the "peace processes". Seeking to understand neoliberalism also in the changes it promotes in social and political realms, we analyze projects focused on Palestinian non-governmental organizations, as well as the mobilization of the notion of a "Palestinian civil society". Particularly, we argue that processes of professionalization and depoliticization of models of social organization, along neoliberal lines, bear negative consequences for the capacities of resistance of a society submitted to an ongoing colonial occupation. We seek to observe neoliberalism's articulations with colonial structures of domination, analyzing international assistance as an agent of neoliberal transformations in colonial contexts, such as that of the occupied Palestinian territories.
\end{abstract}

Keywords: Occupied Palestinian Territories; neoliberalism; colonialism; depoliticization; "peace processes". 


\section{SUMÁRIO}

INTRODUÇÃO...............................................................................................................12

Uma ocupação colonial e econômica...................................................................................................14

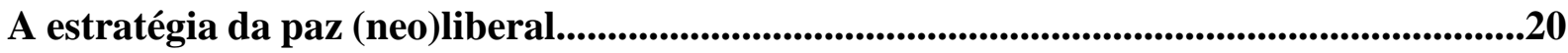

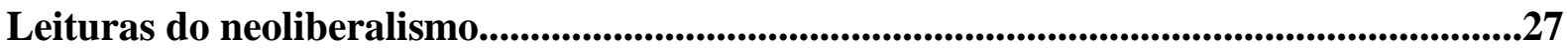

Sínteses e ampliações: neoliberalismo despolitizante em contexto colonial........................33

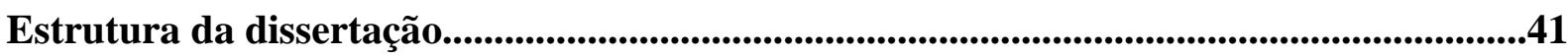

\section{CAPÍTULO 1: "UM INVESTIMENTO NA PAZ": O BANCO MUNDIAL NOS} TERRITÓRIOS PALESTINOS OCUPADOS.................................................................43

1.1. O Banco Mundial e a assistência internacional aos "processos de paz".......................43

1.1.1. As estruturas da assistência financeira internacional aos TPO ..............................47

1.2. O Banco Mundial como ator internacional..............................................................50

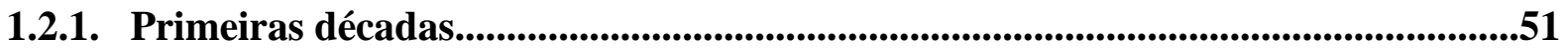

1.2.2. Do ajuste estrutural ao projeto da governança..........................................................55

1.2.3. Um vetor do capitalismo neoliberal e colonial.................................................................62

1.3. O Banco Mundial na Palestina ocupada (1992-1994) .................................................64

1.3.1. “Desenvolvendo os Territórios Ocupados: um investimento na paz"....................66

1.3.1.1. "Uma missão técnica"'.........................................................................................................667

1.3.1.2. "Um Breve Perfil"'...................................................................................................69

1.3.1.3. Uma economia aberta e voltada à exportação.................................................................72

1.3.1.4. Financeirizando os territórios ocupados..........................................................75

1.3.1.5. O papel dos setores público e privado palestinos nos TPO...................................79

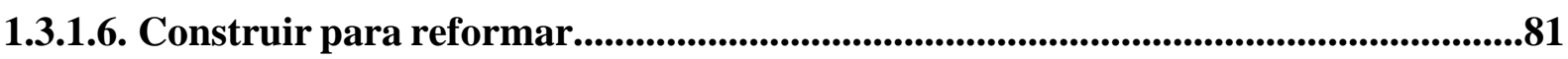

1.4. Limites e contradições da assistência externa: primeiras avaliações..........................84

CAPÍTULO 2: A ZONA INDUSTRIAL DE GAZA: NORMALIZAÇÃO ECONÔMICA

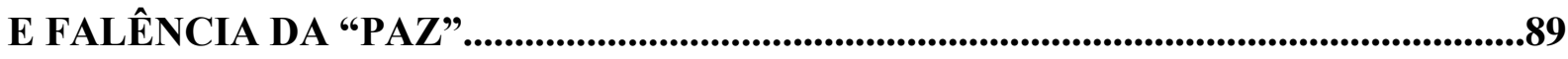

2.1. A ideia de zonas industriais para exportação chega aos TPO (1989-1993) ................89

2.2. As zonas industriais e os "processos de paz" .......................................................................94

2.3. A Zona Industrial de Gaza: anos iniciais (1997-2000) ..........................................98

2.4. Um projeto de risco..................................................................................................105

2.5. O declínio da Zona Industrial de Gaza (2000-2007) .............................................109 
2.6. Balanço e perspectivas: a insistência no desenvolvimento neoliberal.

2.7. Reflexões finais: desenvolvimento ou normalização da ocupação?

CAPÍTULO 3: ASSISTÊNCIA INTERNACIONAL E A TRANSFORMAÇÃO NA

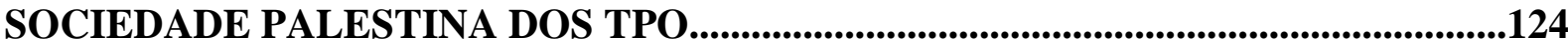

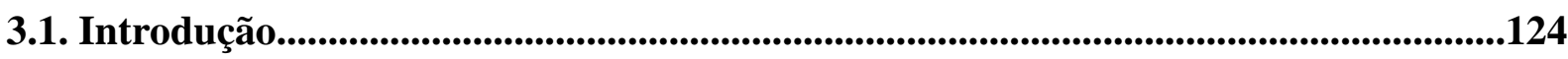

3.2. A sociedade civil neoliberal..........................................................................................127

3.3. A sociedade palestina dos TPO antes de Oslo...............................................................131

3.4. A assistência externa à sociedade palestina dos TPO nos anos de Oslo.....................134

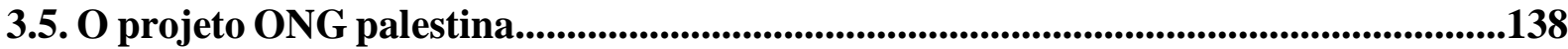

3.5.1. A Organização Gestora do Projeto: a Associação Welfare..........................................141

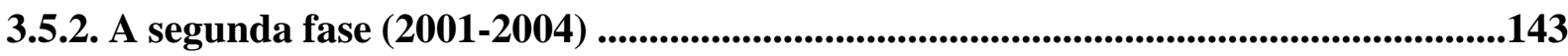

3.6. A USAID e a "sociedade civil palestina" dos TPO..............................................147

3.7. A transformação na sociedade palestina........................................................................150

3.7. Conclusão: a sociedade palestina e a luta anticolonial.............................................155

CONSIDERAÇÕES FINAIS..........................................................................................157

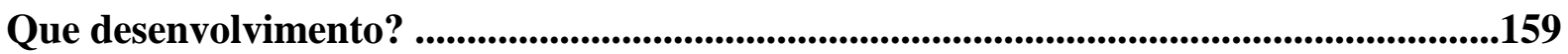

REFERÊNCIAS BIBLIOGRÁFICAS..........................................................................164 


\section{LISTA DE ABREVIAÇÕES}

AHLC - Ad Hoc Liaison Committee

AC - Administração Civil

AID - Associação Internacional de Desenvolvimento

ANP - Autoridade Nacional Palestina

AW - Associação Welfare

BEI - Banco Europeu de Investimentos

BIRD - Banco Internacional para Reconstrução e Desenvolvimento

$\mathrm{CW}$ - Consenso de Washington

CAW - Consórcio Associação Welfare

CCLC - Comitê de Coordenação Local de Ajuda

DLCP - Desenvolvimento Libertador e Centrado nas Pessoas

DP - Declaração de Princípios

FDI - Forças de Defesa Israelenses

GC - Grupo Consultivo

GT - Grupo de Trabalho

IFC - International Finance Corporation

JLC - Joint Liaison Committee

OCB - Organizações Comunitárias de Base

OCDE - Organização para a Cooperação e Desenvolvimento Econômico

OLP - Organização para a Libertação da Palestina

PME - Pequenas e Médias Empresas

TATF - Technical Assistance Trust Fund

TO - Territórios Ocupados

TPO - Territórios Palestinos Ocupados

UNDP - United Nations Development Programme

UNSCO - United Nations Special Coordinator for the Middle East Peace Process

USAID - United States Agency for International Development

ZIG - Zona Industrial de Gaza 


\section{INTRODUÇÃO}

Ao longo dos últimos trinta anos, tem sido frequente o anúncio de novos planos - em geral, norte-americanos - voltados à obtenção da "paz" entre palestinos e israelenses e, de forma mais ampla, em todo o Oriente Médio. Em 2013, o então secretário de Estado norte-americano, John Kerry, divulgou um plano de "paz" para a região, incluindo um pacote de 4 bilhões de dólares em assistência econômica para os territórios palestinos ocupados (TPO) da Cisjordânia e da Faixa de Gaza. Segundo Kerry, a iniciativa liderada pelo governo Obama buscava colocar em andamento um "plano pioneiro para desenvolver uma economia palestina saudável, sustentável e liderada pelo setor privado, que transformará a sorte de um Estado palestino futuro" . Nos meses que se seguiram à divulgação do plano, negociações políticas entre lideranças palestinas e israelenses se deram por mediação norte-americana, mas colapsaram em 2014, com a escalada de ataques na fronteira com Gaza e o início da operação Margem Protetora, pelas forças israelenses.

Mais recentemente, em janeiro de 2020, o governo de Donald Trump anunciou um novo plano para a questão palestina-israelense, intitulado "Paz para a prosperidade" e informalmente denominado de o "Acordo do século". Embora não preveja a criação de um Estado palestino soberano ou o desmantelamento dos assentamentos israelenses existentes nos TPO, o novo plano norte-americano é ainda mais ambicioso que seu antecessor em termos econômicos: promete um valor sem precedentes em auxílio financeiro aos territórios, indicando uma contribuição de mais de 50 bilhões de dólares em projetos de desenvolvimento, ao longo dos próximos dez anos ${ }^{2}$. Para além do "Acordo do século" - veementemente rechaçado pelas lideranças políticas palestinas -, o governo Trump também ficou marcado por impulsionar uma onda de normalizações nas relações entre Israel e países árabes, que tradicionalmente boicotam o Estado judaico pela opressão histórica deste sobre o povo palestino. Ao longo dos últimos meses, Emirados Árabes Unidos, Bahrein ${ }^{3}$, Sudão ${ }^{4}$ e Marrocos ${ }^{5}$ se lançaram em acordos para normalizar relações diplomáticas e econômicas com Israel - no caso do Sudão, em troca de

\footnotetext{
${ }^{1}$ Disponível em: < https://2009-2017.state.gov/secretary/remarks/2013/05/209969.htm>. Acesso: 03. Set. 2020.

${ }^{2}$ Disponível em: <https://interactive.aljazeera.com/aje/2020/the-failed-deals-of-the-century/index.html >. Acesso: 02. Mar. 2020.

${ }^{3}$ Disponível em: <https://www.aljazeera.com/news/2020/9/15/israel-uae-and-bahrain-sign-us-brokerednormalisation-deals $>$. Acesso: 11. Out. 2020.

4 Disponível em: <https://www.aljazeera.com/news/2021/1/6/sudan-says-it-signed-abraham-accords-with-us > Acesso: 08. Jan. 2021.

5 Disponível em: <https://www.aljazeera.com/news/2020/12/10/israel-morocco-agree-to-normalise-relations-inus-brokered-deal>. Acesso: 08. Jan. 2021.
} 
acesso a um pacote de assistência do Banco Mundial no valor de um bilhão de dólares anuais. A normalização entre Israel e Marrocos - que envolve o reconhecimento pelos EUA da ocupação marroquina no Saara Ocidental - foi comemorada pelo primeiro-ministro israelense, Benjamin Netanyahu, como “mais uma grande luz de paz”, e considerada por Trump como "um avanço massivo para paz no Oriente Médio"”.

Iniciativas como as descritas acima tornaram-se comuns a partir da década de 1990, com o início dos chamados "processos de paz" entre Israel e a Organização para a Libertação da Palestina (OLP). Desde então, a busca por "solucionar" a questão palestina tem se centrado nesta palavra - "paz" -, e as estratégias baseadas no estabelecimento de negociações políticas entre palestinos e israelenses têm, como visto, sido acompanhadas por grandes esforços internacionais de assistência econômica. Em geral, a premissa por trás da abordagem predominante é de que a cooperação econômica entre antigos oponentes é benéfica à "paz", isto é, contribui na resolução de conflitos políticos. Segundo essa visão, o desenvolvimento socioeconômico advindo dos investimentos externos - estes possibilitados pelos esforços de negociação política e de normalização de relações - reforçaria positivamente a própria dinâmica política, gerando incentivos para que os atores envolvidos se mantenham comprometidos com acordos firmados ou em negociação.

Busca-se, nessa dissertação, estudar tal abordagem da cooperação para a "paz" em seu início, a partir da década de 1990, através de um recorte específico: analisando as características gerais e os principais efeitos locais da assistência internacional para o desenvolvimento dos territórios palestinos ocupados. Como será discutido, a abordagem da assistência internacional e da cooperação econômica como receita para a "paz" entre israelenses e palestinos foi um dos principais pilares dos “processos de paz”, iniciados em 1993, e é a partir de então que a fórmula se tornou internacionalmente popular, consolidando-se como principal enquadramento a partir do qual a questão palestina é tratada e, como visto, inspirando sucessivas tentativas para soluciona-la. Desde o início dos “processos de paz”, um imenso esforço financeiro internacional tem sido realizado para promover desenvolvimento socioeconômico e político-institucional entre as populações palestinas dos TPO. Proliferaram-se, nas cidades e vilas dos territórios, agências internacionais e complexos projetos de desenvolvimento - urbano, comunitário, industrial, agrícola, da sociedade civil, e assim por diante. Em partes como consequência dessa onda de assistência externa financeira, ao longo dos últimos trinta anos a realidade vivida pela

\footnotetext{
${ }^{6}$ Disponível em: <https://www.aljazeera.com/news/2020/12/10/israel-morocco-agree-to-normalise-relations-inus-brokered-deal>. Acesso: 08. Jan. 2021.
} 
sociedade palestina da Cisjordânia e da Faixa de Gaza tem sofrido profundas transformações, algumas das quais busca-se aqui analisar. Em particular, busca-se enfatizar as transformações incentivadas pelo Banco Mundial - e, em menor grau, pela Agência dos Estados Unidos para o Desenvolvimento Internacional (USAID) ${ }^{7}$ - na Cisjordânia e na Faixa de Gaza, a partir do contexto dos "processos de paz", bem como as consequências dessas transformações para uma sociedade submetida a uma ocupação militar e a um projeto colonial de povoamento.

\section{Uma ocupação colonial e econômica}

Para analisar a realidade dos territórios palestinos ocupados da Cisjordânia e da Faixa de Gaza, essa pesquisa não parte do enquadramento da "paz" mencionado acima, mas busca rejeita-lo e, como será desenvolvido ao longo da dissertação, apontar a mobilização deste enquadramento como fonte importante das transformações aqui observadas na economia, política e sociedade palestinas dos territórios. Negando uma compreensão calcada na busca por atingir a "paz" entre dois $\operatorname{lados}^{8}$, parte-se aqui de uma perspectiva que afirma que, desde 1967 , com o início da ocupação israelense da Cisjordânia e Faixa de Gaza, as sociedades palestinas destes territórios vêm sendo sistematicamente submetidas a um projeto colonial de povoamento $^{10}$ sionista. Nas décadas que se seguiram à ocupação, a realidade palestina local foi marcada, antes de mais nada, pela expropriação de recursos naturais e pela expulsão dos palestinos de suas terras, que em vasta medida passaram para controle do exército israelense ou foram colonizadas por novos assentamentos de população judaica (PAPPÉ, 2006a; WEIZMAN, 2007). A característica específica do colonialismo de povoamento está, precisamente, em seu objetivo de povoar a terra dominada: não se trata apenas de explorá-la economicamente, mas de estabelecer nela novos centros de vida para o colonizador, construir nela uma nova sociedade. Confrontado com a existência de sociedades anteriores, esse modelo de colonialismo se organiza em torno de um princípio ordenador, estruturante, cujo fim está na eliminação das sociedades pré-existentes: é inerente, ao colonialismo de povoamento, uma

\footnotetext{
${ }^{7}$ No original, United States Agency for International Development.

${ }^{8}$ Motivo pelo qual, nessa dissertação, a ideia de "processos de paz" aparece entre aspas, de forma a desnaturalizar um enquadramento que já se tornou tão organizador das maneiras pelas quais se compreende a questão palestina atualmente.

${ }^{9} \mathrm{O}$ projeto colonial de povoamento sionista evidentemente precede em muito a ocupação de 1967. Já no final do século XIX, o projeto sionista de colonizar a Palestina histórica começou a se concretizar na imigração judaica e compra de terras árabes, processo de colonização que atingiu seu ápice na Nakba, discutida adiante. Para os territórios da Cisjordânia e da Faixa de Gaza, será a partir da ocupação de 1967 que o colonialismo de povoamento sionista passará a ser imposto de forma mais sistemática e destrutiva (PAPPÉ, 2006a; MASALHA, 2012).

${ }^{10}$ Tradução do conceito original de "settler colonialism" (DANA; JARBAWI, 2017; VERACINI, 2013; WOLFE, 2006).
} 
"lógica de eliminação" (WOLFE, 2006) das populações nativas, que precisam ser removidas, ter seus vestígios escondidos, suas histórias apagadas. Daí a expulsão e a despossessão de recursos naturais - não apenas terra, mas água, plantações de oliveiras, etc. - constituírem práticas tão frequentes neste modelo de colonialismo: trata-se de esvaziar a terra de seus atuais habitantes, se não pela demolição direta das casas das populações palestinas, então tornando a vida dessas populações cada vez mais inviável. O elemento irredutível do colonialismo de povoamento, aqui, é sua territorialidade - ele é, fundamentalmente, uma disputa pela terra, um projeto para transformar a composição demográfica da terra colonizada (WOLFE, 2006, p.388).

As práticas e mecanismos de dominação colonial da ocupação israelense, multiplicadas desde 1967, inserem-se nesse projeto histórico mais amplo, de controle sionista sobre a Palestina histórica ${ }^{11}$ e de transformação da mesma num Estado exclusivamente judeu. Nas palavras de Mandy Turner e Omar Shweiki (2014, p.2), apesar da profunda fragmentação vivida pelo povo palestino - ela própria uma estratégia de dominação sionista -, pode-se discernir uma ampla figura "[...] de um povo experienciando uma matriz colonial de despossessão, perda de direitos e destruição num período histórico-global considerado como sendo pós-colonial” (grifo nosso). É dessa compreensão que parte a dissertação: embora enfatize especificamente o domínio sionista sobre as populações palestinas dos TPO, analisando as transformações deste domínio entre os anos 1990 e 2000, afirma-se que a ocupação israelense deve ser vista como parte de um regime colonial mais amplo de povoamento sionista sobre toda a Palestina histórica, que teve seu ponto máximo na $\mathrm{Nakba}^{12}$ e continuou a se expandir e se fortalecer desde então, continuando plenamente operante nos dias de hoje.

A expansão dos assentamentos israelenses sobre a Cisjordânia e a Faixa de Gaza são um dos principais exemplos da natureza colonial de povoamento da ocupação sionista dos TPO. Desde os primeiros anos da ocupação, a construção de colônias judaicas nos territórios foi parte da agenda de diferentes governos em Israel, que compreendiam o povoamento das áreas ocupadas tanto como um requisito para garantir a segurança do Estado, quanto como parte de uma narrativa religiosa sionista de retorno do povo judeu à "Judeia e Samaria" (termo judaico para designar o território da Cisjordânia) (PAPPÉ, 2006a, pp.198-202; WEIZMAN, 2007). Em

\footnotetext{
11 O termo "Palestina histórica" é utilizado, na academia como na militância, para se referir ao território que se estende do mar mediterrâneo ao rio Jordão. Em termos atuais, compreende o Estado de Israel - criado em 1948 a partir da expulsão de centenas de milhares de palestinos de suas casas - bem como os territórios palestinos da Cisjordânia e da Faixa de Gaza, ocupados em 1967.

${ }^{12}$ Nakba - "Catástrofe", em árabe - é o termo palestino utilizado para se referir ao processo de limpeza étnica perpetrado pelas forças sionistas em 1947 e 1948, que resultou na destruição de centenas de vilas palestinas e expulsão de centenas de milhares de palestinos, que se tornaram refugiados (PAPPÉ, 2006b).
} 
1993, quando Israel se lançou aos "processos de paz" com os palestinos, mais de 100 assentamentos israelenses existiam nos $\mathrm{TPO}^{13}$, totalizando uma população de mais de 16 mil $\operatorname{colonos}^{14}$. A invasão colonial, como sugere Patrick Wolfe (2006, p.402), deve ser compreendida aqui como uma estrutura, e não como um evento pontual. "[S]ua história não para" (WOLFE, 2006, p.402) após os primeiros grandes atos de expulsão e controle sobre a terra - a catástrofe representada por 1948, ou a ocupação em 1967, por exemplo. Trata-se, portanto, de analisar os mecanismos pelos quais a estrutura colonial de povoamento se repõe, se reproduz, e produz seus efeitos estratégicos de dominação e eliminação das populações palestinas dos territórios ocupados. Como será abordado, essa dissertação analisa um dos vetores que, argumenta-se, passaram a ser fundamentais na reposição - e, portanto, na manutenção - da estrutura colonial israelense a partir dos anos 1990: a assistência financeira internacional.

As políticas sionistas para dominação e exploração econômicas dos palestinos, na Cisjordânia e na Faixa de Gaza, são uma dimensão central da ocupação colonial de povoamento dos territórios, e constitui um dos focos dessa pesquisa. Embora não se subsuma à exploração econômica, possuindo lógicas que a ultrapassam, a dominação colonial sionista não pode ser compreendida sem que se faça referência às reestruturações econômicas operadas por Israel na realidade dos TPO ao longo do tempo (HEVER, 2010). Nas décadas entre 1967 e o início dos “processos de paz", em 1993, a ocupação levou a uma integração econômica forçada e distorcida entre os territórios palestinos e a economia israelense (NAQIB, 2003, p.505; ROY, 1987). Embora se utilizando de diferentes métodos ao longo desses mais de 25 anos, a estratégia econômica de Israel para a Cisjordânia e a Faixa de Gaza buscou, segundo Taghdisi-Rad (2014, p.13), alguns objetivos centrais: (i) incorporar recursos palestinos dos TPO, como trabalho e terra, de forma benéfica à economia israelense; (ii) limitar o desenvolvimento independente da economia palestina dos territórios; (iii) bloqueando assim qualquer demanda por soberania vinda das populações palestinas.

Em termos concretos, nos anos que se seguiram à ocupação, Israel integrou o mercado de trabalho palestino ao seu próprio, estabelecendo uma "política de pontes abertas" por meio da qual a mão de obra barata palestina, vinda dos TPO, tornou-se empregada de empresas

\footnotetext{
${ }^{13}$ B'TSELEM. Disponível em: <https://www.btselem.org/settlements/statistics >. Acesso em: 25 set. 2020.

${ }^{14}$ PEACE NOW. Disponível em: <https://peacenow.org.il/en/settlements-watch/settlements-data/population>. Acesso: 25 set. 2020.
} 
israelenses $^{15}$, que se beneficiavam ao pagar salários menores (FARSAKH, 2016, p.59; HEVER, 2010, pp.8-9). Paralelamente, Israel impôs restrições às atividades industriais, financeiras e agrícolas dos palestinos nos territórios (ROY, 1999, pp. 65-66). Bancos árabes operantes foram fechados ${ }^{16}$, rigorosos critérios para licenciamento de produtores e comerciantes palestinos foram impostos ${ }^{17}$, e o acesso palestino a recursos como água, terra e eletricidade tornou-se responsabilidade da Autoridade Civil (AC) da ocupação. Sobretudo, como afirmado, a expropriação de recursos naturais dos territórios - tomada de terras, poços d'água, plantações das populações palestinas - tornou-se uma realidade $\operatorname{cotidiana}^{18}$ (NAQIB, 2003, pp.503-505; TAGHDISI-RAD, 2014, p.18).

Além disso, as novas políticas comerciais impostas pela ocupação estabeleceram, na prática, uma união aduaneira entre Israel e a economia palestina dos territórios, tornando-as fortemente dependentes de exportações de Israel $^{19}$ e incapazes de concorrer com os produtores israelenses (altamente protegidos) (ROY, 1987; 1999). Após 1967, as tarifas de importação pagas por produtores palestinos dos TPO aumentaram em cerca de quatro vezes, tornando os vizinhos árabes parceiros comerciais muito menos viáveis que antes (NAQIB, 2003, p.503). Desde então, Israel tem sido de longe o principal parceiro comercial dos TPO, que estabeleceram com o poder ocupante um grande déficit comercial (NAQIB, 2003, p.505; TAGHDISI-RAD, 2014).

O arranjo econômico estabelecido com a ocupação, assim, impôs uma relação de integração dependente e forçada das economias palestinas dos territórios em relação a Israel. Grande parte da população passou a trabalhar diretamente para empresas em Israel, o que colocava uma dependência imediata em relação ao nível de salários no país e às permissões de acesso palestino ao território israelense. Diante das restrições para produzir e da concorrência de produtos israelenses, as poucas empresas palestinas que conseguiram se manter atuantes nos

\footnotetext{
${ }^{15}$ Nas décadas após a ocupação, entre 35 e $40 \%$ dos palestinos empregados da Cisjordânia e da Faixa de Gaza trabalhavam em empresas israelenses (FARSAKH, 2016, p.59).

16 A partir da segunda metade da década de 1980, alguns bancos foram reabertos nos territórios, embora em pequeno número (NAQIB, 2003, p.505).

${ }^{17}$ Havia necessidade de permissões das autoridades da ocupação para quase qualquer atividade econômica - desde importações até construções e expansões de casas e comércios ou transformação de manufaturas (NAQIB, 2003, p.505)

${ }^{18}$ Entre 1967 e 1994, Israel confiscou aproximadamente 68\% das terras da Cisjordânia, e 40\% da Faixa de Gaza. Em ambos os casos, as áreas confiscadas foram destinadas à construção de assentamentos ou transformadas em áreas militares fechadas (NAQIB, 2003, p.504).

${ }^{19}$ A imposição de uma união alfandegária entre Israel e os TPO, a partir de 1967, elevou os preços gerais das importações realizadas pelos palestinos, na medida em que os produtores israelenses eram protegidos por altas tarifas. O produtor palestino, que antes importava insumos da Jordânia ou do Egito, passou assim a comprar de empresas israelenses (NAQIB, 2003, p.503).
} 
TPO se tornaram, frequentemente, subcontratantes de capital israelense (ROY, 1999, p.67; TAGHDISI-RAD, 2014, p.16).

Apesar de benefícios econômicos identificáveis e da melhoria de vários indicadores socioeconômicos, nas primeiras décadas após o início da ocupação as políticas de expropriação e restrição descritas acima fizeram com que a base produtiva da economia dos territórios se mantivesse estagnada, quando não regredisse. Atividades industriais e agrícolas diminuíram em prol do setor de serviços, consolidando um desequilíbrio setorial que se somava ao desequilíbrio mais geral no mercado de trabalho palestino (ROY, 1999, p.67). Como dito, sem opções de emprego na economia doméstica, trabalhadores palestinos progressivamente se voltaram ao emprego em Israel, assim como agricultores que não conseguiram manter atividades locais financeiramente viáveis (ROY, 1987, p.84). Aprofundava-se, assim, a forte dependência da economia dos TPO em relação a fontes externas de renda - os benefícios gerados à renda doméstica, em outros termos, não vinham de atividades econômicas realizadas na própria economia palestina (FARSAKH, 2016, pp.59-60; ROY, 1999, p.67).

Ao longo da década de 1980, enfrentando uma forte crise econômica - marcada, entre outros aspectos, por altíssimos níveis inflacionários -, Israel se lançou em reformas de caráter neoliberal $^{20}$ (FISCHER, 1987), cujas consequências para os TPO expressaram a forte dependência econômica destes em relação à economia israelense. As quedas nos salários em Israel afetaram as rendas familiares palestinas, e aumentou o desemprego entre os palestinos dos territórios (CLARNO, 2018; HEVER, 2010, p.11). As políticas israelenses para a ocupação dos territórios palestinos também foram transformadas no período: Israel progressivamente passou a buscar estratégias para diminuir os custos da ocupação. Antes dos anos 1990, isso se refletiu em novas autonomias conferidas às autoridades municipais dos TPO, em áreas como saúde, serviços sociais e saneamento, ao passo que decisões estratégicas sobre economia, planejamento, e gestão de recursos mantiveram-se, de forma previsível, sob a responsabilidade da autoridade da ocupação (TAGHDISI-RAD, 2014, p.17).

Com o início da primeira Intifada ${ }^{21}$, em 1987, o imperativo de uma ocupação menos custosa foi associado à necessidade de garantir a segurança de Israel, ênfase que se intensificaria a partir dos anos 1990, com a Guerra do Golfo e a expulsão de centenas de milhares de

20 Disponível em: <https://www.haaretz.com/israel-news/business/.premium-july-1-1985-the-day-israelicapitalism-was-born-1.5375114>. Acesso em: 05 out. 2020.

${ }^{21}$ Intifada é o termo utilizado para se referir aos levantes generalizados palestinos contra a ocupação israelense. A primeira Intifada se iniciou em 1987, e a segunda, já após os "processos de paz", começou em 2000. 
palestinos que trabalhavam em países como o Kuwait ${ }^{22}$. A partir de então, a política de "integração seletiva" com os territórios palestinos seria submetida a um "separacionismo", vindo do imperativo da segurança: Israel passou a impor, cada vez com maior frequência, fechamentos parciais ou completos nas fronteiras com a Cisjordânia e a Faixa de Gaza, bloqueando os fluxos da mão de obra palestina. Nesse contexto, a demanda por trabalho palestino em Israel entrou em forte queda a partir do fim dos anos 1980, causando reduções importantes na renda familiar palestina ${ }^{23}$ (ROY, 1999, p.66). Em sentido semelhante, um sistema de permissões de trabalho - sujeitas à revogação - passou a organizar a entrada de trabalhadores palestinos em Israel, a partir do início da década de 1990 (TAGHDISI-RAD, 2014, pp. 20-21).

A busca por conciliar imperativos de segurança e de exploração (integração seletiva) dos recursos da economia palestina levou, assim, a transformações nas práticas de controle econômico de Israel para os TPO. Contudo, como mencionado, Taghdisi-Rad (2014) argumenta que as mudanças de método não refletiram uma alteração significativa nos objetivos estratégicos mais amplos de Israel com a ocupação. O exemplo das zonas industriais, tratado no segundo capítulo da dissertação, é ilustrativo dessa reestruturação de um arranjo econômico para a manutenção de seus objetivos principais. Através do estabelecimento de zonas industriais para exportação - uma das iniciativas lançadas por Israel no final dos anos 1980 -, em pontos de fronteira com os territórios palestinos, Israel continuaria se beneficiando de mão de obra palestina barata, sem que os trabalhadores precisassem entrar em território israelense. Em sentido semelhante, no mesmo período buscou-se aprofundar as tendências de terceirização brevemente citadas acima: com leves relaxamentos nas restrições às atividades financeiras, industriais e comerciais, Israel buscou consolidar as firmas palestinas atuantes nos TPO como subcontratantes de suas próprias empresas. Transferiu-se, assim, parte (de baixo valor) do processo produtivo para os territórios, evitando-se novamente o emprego direto de grandes quantidades de trabalhadores palestinos em território israelense.

Apesar dos ajustes realizados nas políticas para a ocupação ao longo dos anos 1980 e início dos 1990, as principais relações estruturais entre as economias de Israel e dos TPO se mantiveram - a integração desigual, as expropriações e restrições (embora relativamente

\footnotetext{
${ }^{22}$ Após o apoio de Yasser Arafat a Saddam Hussein, quando da invasão iraquiana do Kuwait, diversos países árabes passaram a expulsar populações palestinas locais e cortaram os auxílios financeiros constantemente destinados à OLP (ROY, 1999; TAGHDISI-RAD, 2014).

${ }^{23} \mathrm{O}$ que foi agravado com o fim da Guerra do Golfo e a expulsão dos palestinos que trabalhavam ali. As populações dos TPO perderam, assim, uma de suas principais fontes de renda externa (para além do trabalho em Israel): remessas enviadas às famílias locais por palestinos que trabalhavam em países do Golfo (ROY, 1999, p.66).
} 
relaxadas para alguns setores econômicos). O conceito mais amplamente utilizado para conceber a condição resultante das economias da Cisjordânia e da Faixa de Gaza, após as duas primeiras décadas dessas políticas de ocupação, é o de “des-desenvolvimento" (ROY, 1987, p.56; 1999, pp.64-66). A expropriação contínua de recursos, a integração desigual e a externalização das fontes de renda palestina em relação a sua própria economia, bem como as inúmeras restrições ao desenvolvimento de instituições (governamentais, mas também privadas, como instituições de crédito), privaram a economia dos TPO de elementos fundamentais para que qualquer tipo de desenvolvimento, por mais distorcido que seja, pudesse acontecer. $\mathrm{O}$ crescimento relativo da renda palestina, como discutido, precisa ser compreendido a partir desse contexto, incluindo na análise as capacidades gerais dos setores econômicos desenvolvidas no processo de crescimento (ROY, 1987, pp. 56-57).

Cunhada por Sara Roy (1987), num amplo estudo sobre a economia da Faixa de Gaza sob ocupação, a noção de des-desenvolvimento conecta transformações econômicas estruturais com a dimensão política da soberania. Afirma-se que, sem soberania sobre a terra e seus recursos (água, espaço aéreo, controle de fronteiras, e assim por diante), mesmo níveis significativos de crescimento econômico não significarão desenvolvimento: o desenvolvimento sustentável, ao longo do tempo, é impossível sem soberania. O conceito de desdesenvolvimento, assim, dá conta da natureza estruturante da ocupação israelense sobre a economia dos TPO, e permite pensar um arranjo colonial enquanto variável econômica, isto é, enquanto fator chave para explicar a realidade econômica dos territórios, bem como as perspectivas de transformação dessa realidade (FARSAKH, 2016, p.59; ROY, 1987; 1999). Nessa dissertação, parte-se da noção de des-desenvolvimento como diagnóstico da condição socioeconômica palestina, resultante de décadas de uma ocupação colonial de povoamento. $\mathrm{O}$ conceito será retomado, ao longo dos próximos capítulos, com o intuito de destacar sua relevância diante das transformações promovidas nos TPO pela assistência financeira internacional, a partir dos "processos de paz" dos anos 1990.

\section{A estratégia da paz (neo)liberal}

As transformações e continuidades nas políticas de ocupação israelenses, ao longo das décadas de 1980 e 1990, precisam ser inseridas numa compreensão mais ampla sobre as transformações neoliberais em andamento no período, a nível regional e global. Com o fim da Guerra Fria, uma nova ordem mundial passou a ser afirmada, caracterizada pela vitória da globalização capitalista e expansão da democracia liberal a nível mundial (FUKUYAMA, 
1989; 1992; HUNTINGTON, 1996). Em sintonia com as tendências globais, em Israel passouse também a defender um "novo Oriente Médio" (PERES, 1993): a expansão de relações econômicas mutuamente benéficas entre países da região forjaria novas relações de vizinhança, estabilizando, a partir de princípios liberais de cooperação e interdependência econômicas, uma região historicamente marcada por rivalidades e forte militarismo. O início da década de 1990 foi, assim, caracterizada por importantes mudanças globais e regionais: num contexto de aparente unipolaridade mundial, e de avanço global da neoliberalização como novo paradigma de organização política e econômica das sociedades, no Oriente Médio isso se refletiu numa nova estratégia - calcada na transformação de relações econômicas - para atingir a "paz" regional (SHAFIR; PELED, 2000; RAM, 2008).

Israel sempre havia enfrentado um boicote econômico de seus vizinhos árabes, em função da opressão histórica sobre o povo palestino. Ao longo da década de 1980, no contexto de crise econômica e de pressões por liberalizar a economia - por exemplo, por aprofundar o direcionamento para exportação -, superar o boicote árabe e acessar mercados da região tornouse mais importante que antes. É nesse cenário que se insere a busca por difundir a ideia de "um novo Oriente Médio", e é a partir dele que deve ser compreendida a busca israelense por iniciar “processos de paz” com a Organização para a Libertação da Palestina, no início dos anos 1990. Como discutido adiante, os posicionamentos de Israel nos anos que se seguiram aos "processos de paz" reforçam a compreensão de que os reais objetivos do país, com as transformações buscadas, era antes realizar ajustes em suas relações diplomáticas e econômicas com os vizinhos árabes do que, de fato, conceder algum nível de soberania a um futuro Estado palestino (HADDAD, 2016, pp.261-263; SHAFIR; PELED, 2000).

Em 1991, alguns meses após a vitória da coalizão contra o Iraque, na Guerra do Golfo, a nova ordem mundial liberal parecia estar consolidada e as condições para reestruturar as relações no Oriente Médio pareciam ideais ${ }^{24}$. Entre outubro e novembro, realizou-se em Madrid uma ampla conferência de paz entre Israel e países árabes, com o objetivo de iniciar negociações para o estabelecimento de relações diplomáticas e de cooperação econômica. A delegação israelense vetou a participação, na conferência, de uma delegação palestina independente, de

\footnotetext{
${ }^{24}$ A Guerra do Golfo havia trazido condições catastróficas para a liderança da OLP, que se viu isolada em termos políticos e enfraquecida financeiramente, devido à retirada de apoio por parte dos países árabes. Assim, a organização entrou na década de 1990 bastante enfraquecida, na medida em que ascendiam nos TPO, no contexto da Intifada, novas lideranças palestinas locais - sobretudo grupos islâmicos como o Hamas. A opção por entrar em negociações com Israel, assim, é constantemente interpretada como uma tentativa da OLP de manter, num momento de enfraquecimento, sua posição de liderança na luta palestina travada nos territórios (HADDAD, 2016; SAID, 2003).
} 
forma que os representantes palestinos atenderam à Madrid como parte da delegação jordaniana.

Em continuidade à conferência, uma série de reuniões bilaterais ocorreram em Washington, D.C, no ano que se seguiu, e uma conferência multilateral foi realizada em Moscou, com participação de israelenses e, novamente, de uma delegação conjunta de jordanianos e palestinos. Em paralelo às conferências multilaterais e às reuniões bilaterais, negociações secretas foram iniciadas entre a liderança da OLP e o governo israelense, com mediação do governo da Noruega. Como resultado, em 1993 anunciou-se - para surpresa dos próprios negociadores palestinos em Washington (KHALIDI, RASHID, 2006) - o início de "processos de paz" formais entre israelenses e palestinos, que consistiriam na assinatura de uma série de acordos de cooperação nos anos seguintes. Enquanto conjunto, os documentos desde então ficaram conhecidos como os "acordos de Oslo".

Em setembro de 1993, o primeiro-ministro israelense Yitzhak Rabin e o líder da OLP, Yasser Arafat, assinaram na Casa Branca a Declaração de Princípios (DP). No documento, os palestinos renunciavam à resistência armada e reconheciam o direito de Israel a existir; o governo israelense, por sua vez, reconhecia a OLP como única representante legítima do povo palestino, sem, contudo, afirmar seu compromisso com um Estado palestino soberano (BRYNEN, 2000; HADDAD, 2016; SAID, 2003). A Declaração de Princípios sintetizou a abordagem geral adotada para os "processos de paz": ao longo de um período de cinco anos, seriam assinados acordos transitórios entre israelenses e palestinos, visando estabelecer uma autoridade palestina de autonomia limitada nos TPO e transferir para ela a gestão de porções do território e de esferas da vida das populações palestinas nele presentes (como a educação, o policiamento, etc.). Questões cruciais para os palestinos, no cronograma de negociações estabelecido, foram classificadas como "questões de status permanente". Negociações em torno delas só seriam iniciadas após um período inicial de três anos, numa abordagem que visava construir confiança entre os "lados", atingindo primeiro os objetivos de mais fácil negociação e solidificando relações de cooperação para, num segundo momento, abordar os tópicos mais intratáveis (BRYNEN, 2000, pp.55-56). As questões de status permanente compreendiam o direito de retorno dos refugiados palestinos ${ }^{25}$; os assentamentos israelenses construídos nos territórios ocupados; o status final de Jerusalém; os arranjos finais de segurança; bem como as fronteiras finais entre Israel e o que supostamente viria a ser um Estado palestino independente.

\footnotetext{
${ }^{25} \mathrm{O}$ direito dos palestinos refugiados de retornarem às terras de onde foram expulsos foi afirmado, pela primeira vez, na resolução ${ }^{\circ} 194$ da ONU, em dezembro de 1948.
} 
Dentre as principais transformações trazidas pelos novos acordos - assinados em 1994, 1995 e em diante -, estiveram o estabelecimento da Autoridade Nacional Palestina (ANP) e uma nova divisão espacial dos territórios palestinos ocupados em três áreas. Nas áreas A (os principais centros urbanos palestinos), a nova autoridade autônoma teria controle civil e militar; em áreas B (pequenas regiões de transição, em geral contornando as cidades palestinas), a ANP teria controle civil, mas Israel manteria domínio militar ${ }^{26}$; Israel manteria total controle sobre a área $\mathrm{C}$, território contíguo que representa a maior parte dos TPO e efetivamente circunda os centros urbanos, transformando-os em enclaves de autogoverno não-soberano palestino. É importante ressaltar que, apesar dessa divisão, as forças israelenses mantiveram completa soberania sobre a Cisjordânia e a Faixa de $\mathrm{Gaza}^{27}$. A partir de 1994, assim, a Autoridade Nacional Palestina assumiu jurisdição sobre dezenas de assuntos civis das populações de cidades dos territórios $^{28}$ (BRYNEN, 2000; FARSAKH, 2016). Estabeleceu-se também uma polícia palestina, presente em áreas A e B e cuja atuação passou a ocorrer, em larga medida, de forma coordenada com as forças israelenses da ocupação, nos termos estabelecidos pelos acordos de paz $^{29}$. A Figura 1, a seguir, ilustra a divisão territorial que passou a vigorar na Cisjordânia, a partir dos anos 1990.

\footnotetext{
${ }^{26}$ Nas áreas B, a nova autoridade seria responsável pela manutenção da ordem civil, mas as forças militares israelenses mantinham-se responsáveis pela segurança (BRYNEN, 2000, p.60).

${ }^{27} \mathrm{O}$ que se refletiu, por exemplo, em inserções das forças israelenses em cidades palestinas (áreas A) em certos episódios, de forma coordenada ou não com a polícia palestina.

${ }^{28}$ Inicialmente, apenas Jericó e Gaza. Em 1995, a assinatura do "acordo de Oslo II" estabeleceu novas "retiradas" israelenses e a expansão da jurisdição da ANP para a área A, seguindo a divisão descrita (BRYNEN, 2000, pp. 56-61).

${ }^{29}$ Os arranjos de cooperação militar entre as forças israelenses e a nova polícia palestina também foram detalhadas em 1995, com o acordo de Oslo II (BRYNEN, 2000)
} 
Figura 1: Divisão da Cisjordânia em áreas A, B e C, em 2011.

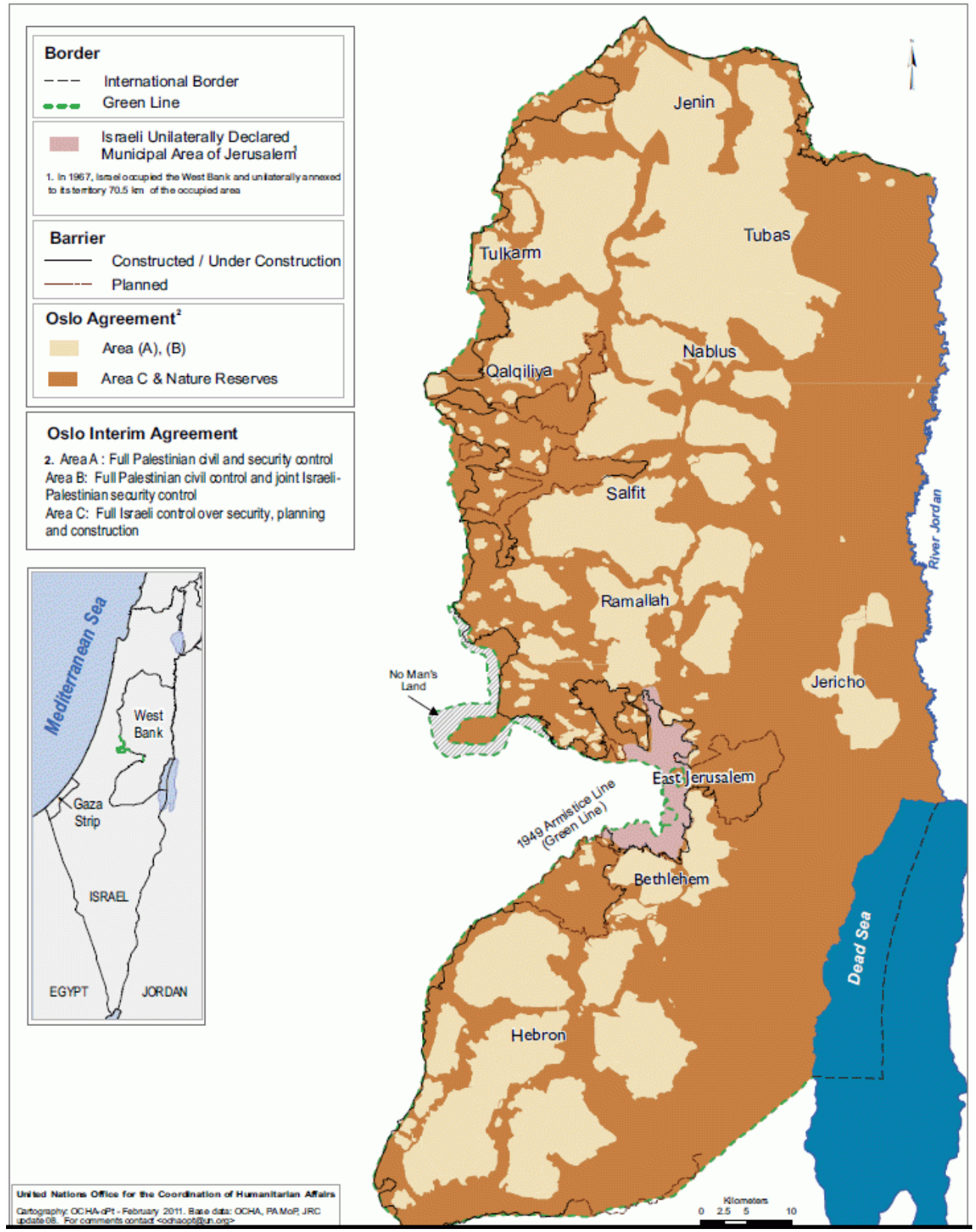

Fonte: United Nations Office for the Coordination of Humanitarian Affairs, 2011. Disponível em: <https://www.un.org/unispal/west-bank-area-c-ocha-map/>. Acesso em: 25 jun. 2019.

Os acordos de Oslo também estabeleceram novos arranjos econômicos entre os territórios ocupados e Israel. A autoridade palestina obteve controle sobre taxações indiretas e uma Autoridade Monetária foi estabelecida (BRYNEN, 2000, pp.56-57). Contudo, a relação básica de integração dependente entre as duas economias foi pouco alterada, e os novos acordos econômicos representaram antes de mais nada uma institucionalização dos arranjos econômicos anteriores (FARSAKH, 2016). A união aduaneira que já existia de fato entre Israel e os 
territórios palestinos, por exemplo, foi ratificada no Protocolo de Paris sobre relações econômicas, embora os negociadores palestinos tenham buscado negociar por um outro arranjo comercial, como uma zona de livre comércio ${ }^{30}$. Israel manteve, ainda, controle sobre todas as fronteiras dos TPO, recolhendo impostos alfandegários e repassando-os - assim como uma série de impostos indiretos - aos orçamentos da ANP. Por fim, a nova autoridade não poderia estabelecer moeda própria, e o shekel israelense continua até hoje a ser a moeda corrente na Cisjordânia e na Faixa de Gaza (TAGHDISI-RAD, 2014, p.23).

Menos de três semanas após a Declaração de Princípios entre Israel e a OLP, já em primeiro de outubro de 1993 foi realizada, em Washington, D.C., uma conferência que reuniu 42 doadores internacionais - entre representantes de governos nacionais e agências multilaterais - dispostos a contribuir economicamente com os "processos de paz" recém-iniciados (BANCO MUNDIAL; UNSCO, 1999, p.8). Na “Conferência para Apoiar a Paz no Oriente Médio”, mais de US\$2 bilhões foram prometidos pelos participantes em assistência financeira aos territórios palestinos para os quatro anos seguintes, montante que se elevaria conforme novos compromissos fossem sendo firmados pelos doadores. O objetivo era, fundamentalmente, financiar projetos de desenvolvimento social, econômico e político-institucional nos territórios, estabilizando a conflituosa situação local e apoiando os "processos de paz" em andamento (BANCO MUNDIAL, 1994a, p.vii).

O início dos "processos de paz” marcou, assim, um aumento significativo na presença da comunidade internacional de assistência externa ${ }^{31}$ nos TPO, e o objetivo de desenvolver a Cisjordânia e a Faixa de Gaza se tornou um problema internacional de primeira grandeza. Dados coletados pelo Programa de Desenvolvimento da ONU - que empreendeu uma primeira tentativa de agrupar as informações sobre assistência externa aos TPO - indicam que os montantes oferecidos em auxílio ao desenvolvimento de fato se elevaram a partir dos anos 1990, com o início dos "processos de paz” de Madrid e, em seguida, de Oslo. De aproximadamente US\$174 milhões prometidos em 1992, no ano seguinte esse valor subiu para US\$263 milhões ${ }^{32}$. Esse aumento na assistência internacional aos TPO, no período, acompanhou uma tendência

\footnotetext{
${ }^{30} \mathrm{O}$ que permitiria à nova autoridade palestina estabelecer suas próprias tarifas de importação em relação a parceiros comerciais que não Israel.

${ }^{31}$ Composta por agências de assistência externa de outros países, como a USAID, bem como por organizações internacionais e instituições financeiras internacionais, como o Banco Mundial, o Fundo Monetário Internacional e o Banco Europeu de Investimentos.

${ }^{32}$ Referente aos valores prometidos. Como mostra Brynen (2000, p. 45), o Comitê de Assistência para o Desenvolvimento da OCDE aponta que, em 1993, o valor desembolsado em assistência para os TPO foi de US\$ 182 milhões. O significativo aumento nas promessas de desembolso, contudo, já indicam o renovado interesse internacional em financiar o desenvolvimento dos TPO.
} 
mais geral de crescimento nos valores de auxílio externo destinados a países em situação de (pós-)conflito. De 1990 a 1995, a assistência humanitária e para refugiados oferecidas por canais bilaterais, pela comunidade de doadores ocidentais, triplicou de valor, ao passo que a assistência multilateral de mesmo tipo foi de US\$ 1 a US\$2 bilhões no período. A assistência total para países em situação de conflito ou pós-conflito, no período de 1993 a 1997, foi de mais de US\$ 11 bilhões por ano, o que significou um aumento de $8 \%$ em relação a toda a assistência oficial ao desenvolvimento oferecida por países da Organização para a Cooperação e Desenvolvimento Econômico (OCDE). Além disso, dentre os cinco principais recipientes de assistência da USAID ${ }^{33}$, no período, todos eram países recentemente saídos de situação de conflito, tendência que também se observa na composição da carteira de crédito do Banco Mundial: em 1998, 16\% dos empréstimos da instituição destinavam-se a países saídos de situações de conflito, contra menos de 8\% apenas dez anos antes (BRYNEN, 2000, pp.6-7).

Percebe-se, portanto, um aumento expressivo no interesse da comunidade de assistência internacional em financiar projetos voltados à resolução de situações de conflito. Com o fim da Guerra Fria e a recente unipolaridade capitalista, ganhou força internacionalmente, como solução apropriada para instabilidades sociopolíticas locais e regionais, o financiamento externo a programas de peacebuilding, statebuilding, desenvolvimento socioeconômico e governança (CHANDLER, 2010; PARIS, 1997; 2002) - cuja implementação nas mais variadas localidades visou reformar estruturas políticas, econômicas e sociais, em geral seguindo um modelo único, internacionalmente aceito e centrado nas forças de mercado - que será objeto dessa pesquisa. Aqui, compreende-se o aumento na assistência externa a situações de instabilidade, relatado acima, como parte de um projeto mais amplo de engenharia social, econômica e política, em ascensão no período analisado, e que teve no Banco Mundial um de seus principais vetores: o neoliberalismo. Em outras palavras, o financiamento externo para o desenvolvimento se consolidou, na década de 1990, como um importante instrumento na difusão desse novo modelo de organização política e econômica das sociedades. O argumento por trás, como dito, era o de que a reestruturação de tais sociedades em chave neoliberal levaria à diminuição nos níveis locais de conflito, na medida em que se proliferariam melhorias econômicas e institucionais que, por sua vez, inibiriam as causas de instabilidade.

Cenário semelhante se desenrolou na Cisjordânia e na Faixa de Gaza, a partir do início da década de 1990. Com o aumento da assistência externa no contexto dos "processos de paz",

${ }^{33}$ A USAID foi um dos principais atores a participar do esforço de assistência aos TPO, analisado neste trabalho. 
os territórios palestinos ocupados se tornaram um terreno propício para a aplicação dessas novas concepções predominantes para a resolução de conflitos, construção estatal e desenvolvimento socioeconômico/político-institucional. A questão palestina foi assim enquadrada, pela comunidade internacional, essencialmente como um problema de resolução de um conflito entre "dois lados", de certa forma equivalente a outras situações de instabilidade civil e ausência de estruturas estatais. Diante de tal equivalência, a solução concebida não seria diferente daquela aplicada em outros locais: a assistência financeira, acreditava-se, estabeleceria as bases sociais, econômicas e institucionais para o desenvolvimento de longo prazo e a melhoria das condições de vida palestinas, rompendo com ciclos de violência então existentes. A assistência financeira internacional, em outras palavras, passa a operar na década de 1990 uma marcante função de pacificação - já existente em décadas anteriores, mas, como visto, em marcante crescimento no final do século XX.

Partindo deste amplo contexto, brevemente discutido, realiza-se nessa dissertação um estudo sobre o papel que a assistência financeira externa - sobretudo na figura do Banco Mundial - teve nas transformações impulsionadas pelos "processos de paz" nos territórios palestinos ocupados. Aqui, buscou-se delinear o contexto internacional e local em que a atuação do Banco se deu: globalmente, a ascensão do neoliberalismo e de uma nova ordem mundial capitalista; regional e localmente, a busca por transformar as relações entre países árabes e Israel, e por reestruturar a ocupação colonial deste sobre os territórios palestinos da Cisjordânia e da Faixa de Gaza. Nos próximos capítulos, avança-se na descrição histórica dos "processos de paz" ao longo dos anos 1990, sobretudo a partir da perspectiva do Banco Mundial - principal líder dessa comunidade de assistência internacional atuante nos TPO - e das transformações impulsionadas por suas iniciativas. Antes disso, cumpre realizar uma discussão teórica mais detida sobre a própria noção de neoliberalismo, conceito que dá sentido aos processos analisados nessa pesquisa.

\section{Leituras do neoliberalismo}

Atualmente, poucos autores críticos negariam que o neoliberalismo constitui um dos principais desafios colocados às esquerdas no mundo. No entanto, este aparente consenso crítico termina precisamente no momento de definir, em termos conceituais, o que se deve entender por "neoliberalismo". A ascensão do fenômeno nas últimas décadas tem sido objeto de variadas análises, cada uma enfatizando - a partir de perspectivas teóricas distintas dimensões específicas do conceito. Aqui, busca-se dialogar com algumas leituras críticas sobre 
o neoliberalismo que, argumenta-se, contribuirão para o estudo das intervenções realizadas pela comunidade de assistência internacional na Palestina ocupada, a partir do contexto dos “processos de paz".

A primeira perspectiva aqui mobilizada para compreender a neoliberalização da Cisjordânia e da Faixa de Gaza é o marxismo, ou materialismo histórico. O neoliberalismo é compreendido, pela literatura marxista, como um momento de intensificação do capitalismo, aprofundamento de sua exploração. Como corpo teórico, as análises marxistas localizam a ascensão neoliberal do final do século XX dentro do sistema de acumulação mais amplo no qual tal ascensão ocorreu, isto é, compreendem as dinâmicas neoliberais remetendo-as às características estruturais do capitalismo (DUMÉNIL; LÉVY, 2005; 2007; 2013; SAADFILHO, 2015). O neoliberalismo tem assim, dentro de suas diversidades conjunturais, características centrais comuns, que só podem ser compreendidas a partir da lógica básica de reprodução do sistema capitalista: ele é, em si, um sistema de acumulação, "uma estrutura material de reprodução econômica, social e política" (SAAD-FILHO, 2015, p.59). Historicamente, o neoliberalismo representa uma fase do capitalismo, seu "modo de existência" contemporâneo - marcado pela financeirização ilimitada, globalização, aumento da desigualdade e concentração de riquezas, intensificação e flexibilização dos regimes de trabalho, que acompanha uma diminuição dos salários reais (HARVEY, 2008; SAAD-FILHO, 2015).

Segundo o materialismo histórico, o capitalismo enquanto sistema é essencialmente contraditório, levando inevitavelmente a crises que, quando ocorrem, precisam ser resolvidas por reestruturações sistêmicas. É nesse sentido que o neoliberalismo é uma nova fase, uma reestruturação do sistema capitalista. A década de 1970 foi, a nível global, marcada pelo fim de uma configuração histórica do capitalismo - o keynesianismo ou "liberalismo embutido" (HARVEY, 2008, p.20) -, cujo esgotamento se manifestou através de uma crise de acumulação. O surgimento histórico do neoliberalismo enquanto novo modelo de organização política, econômica e social aparece, assim, como o reajuste "necessário" realizado no sistema capitalista: ele é o aprofundamento de um sistema cujo objetivo é a exploração das classes trabalhadoras a nível mundial (DUMÉNIL E LÉVY, 2007; 2013).

Sendo uma intensificação da exploração capitalista, o neoliberalismo precisa também ser compreendido como um momento histórico na luta de classes, caracterizado por uma ofensiva das classes capitalistas, muitas vezes liderada pelo Estado, contra as classes trabalhadoras. O tema da desigualdade econômica e da concentração mundial de renda é 
ilustrativo neste ponto. Para o marxismo, o período do pós-Segunda Guerra pode ser considerado como a consolidação de um compromisso de classes ${ }^{34}$ (DUMÉNIL E LÉVY, 2007), em que o poder relativo da classe capitalista caiu consideravelmente ${ }^{35}$ em diversos países. A situação permaneceu sustentável para as elites econômicas enquanto o modelo do "liberalismo embutido" garantiu crescimento econômico constante. No entanto, com a crise de acumulação do fim dos anos 1960 e início dos 1970, tal arranjo não poderia mais ser aceito. Com a estagnação do crescimento e a queda dos valores de ativos, o controle da riqueza ${ }^{36}$ pelo $1 \%$ mais rico dos Estados Unidos despencou. O efeito foi o rompimento do compromisso de classe: as elites econômicas enxergaram na crise uma concreta ameaça a seus controles sobre o capital, iniciando uma atuação mais vigorosa para garantir a manutenção de suas posições (DUMÉNIL E LÉVY, 2007; 2013; HARVEY, 2008). Como consequência desse avanço de classe, um dos principais efeitos das reestruturações neoliberais foi, além do sistemático enfraquecimento do trabalho, o aumento da concentração de renda ${ }^{37}$ e da desigualdade social (HARVEY, 2008, pp.25-26). Em resumo, a intensificação da concentração de renda segue, quase como lei, a implantação do neoliberalismo, o que dá sustentação empírica à interpretação marxista de que o mesmo deve ser compreendido, conceitualmente, como um projeto político de restituição do poder de classe das elites econômicas (DUMÉNIL E LÉVY, 2007; 2013; HARVEY, 2008; SAAD FILHO, 2015).

No caso israelense, como discutido nas seções anteriores, a década de 1980 representou a crise de um modelo de organização político-econômica marcado por um Estado grande e atuante na economia, bem como o enfraquecimento das organizações da classe trabalhadora israelense. Elevou-se progressivamente a pressão do empresariado nacional israelense por menores custos de produção (frequentemente, menores salários) e maior abertura econômica, e a partir da metade da década tais pressões se traduziram em profundas reformas econômicas (SHAFIR; PELED, 2000). Em outros termos, o processo de neoliberalização israelense iniciado

\footnotetext{
${ }^{34}$ Duménil e Lévy (2007, p. 2) denominam o período de "compromisso keynesiano ou social-democrata".

${ }^{35} \mathrm{Se}$, antes da guerra, o $1 \%$ mais rico da população norte-americana concentrava $16 \%$ da renda nacional, depois dela este número caiu pela metade, mantendo-se assim até meados da década de 1970 (HARVEY, 2008, p.25).

${ }^{36}$ Diferentemente do controle da renda, o controle da riqueza pelo $1 \%$ mais rico do país havia se mantido relativamente constante ao longo de todo o século XX (HARVEY, 2008). De acordo com Duménil e Lévy (2007), este valor, que era de aproximadamente $30 \%$ entre a guerra e o início da década de 1970, caiu para $22 \%$ nos anos seguintes.

${ }^{37}$ A proporção da renda nacional nas mãos do $1 \%$ mais rico da sociedade norte-americana, por exemplo, disparou com a implementação de políticas neoliberais, atingindo $15 \%$ (ou seja, mais que dobrando) em cerca de duas décadas. O salário médio real do trabalhador norte-americano, em relação ao de um CEO, passou de uma proporção de 30 para 1, no início da década de 1970, para aproximadamente 500 para 1, no final do século (HARVEY, 2008, pp.25-26).
} 
nos anos 1980, no qual se inserem os "processos de paz" da década seguinte, deve ser compreendido também como um avanço da classe capitalista israelense em sua busca por manutenção de taxas de lucro que se encontravam em perigosa tendência de declínio.

É importante, contudo, ressaltar que a concepção de neoliberalismo como um projeto político e histórico de classe não significa afirmar que ele foi objeto de uma elaboração e aplicação conscientes, concertadas e sistemáticas. Ao contrário, sua generalização enquanto modelo de organização econômica, social e política foi bastante errática, diversa, fragmentada e geograficamente desigual. Assim, seria um equívoco teórico atribuir o surgimento do neoliberalismo a algum tipo de plano, previamente concebido em sua inteireza por um sujeito como o capital ou a classe capitalista mundial (HARVEY, 2008). Antes, como se buscou expor, o neoliberalismo deve ser compreendido aqui como desenrolar histórico da lógica capitalista, de sua dinâmica sistêmica e contraditória de exploração, acumulação e expansão. Sua difusão a nível internacional se dá, antes, através de vetores erráticos, mais ou menos coerentes entre si, do que por meio de qualquer agência una. Nessa dissertação, como dito, enfatiza-se um destes vetores da difusão neoliberal - a assistência financeira internacional -, sem negar a absoluta relevância de outros atores igualmente envolvidos na consolidação global do neoliberalismo. Neoliberalismo, portanto, enquanto sistema intensificado, enquanto aprofundamento de uma estrutura material de reprodução do econômico, do político, do social, do cultural, do ideacional. Seriam estas, numa perspectiva epistemológica materialista histórica, as dimensões conceituais centrais do fenômeno neoliberal.

Para além da perspectiva marxista, uma segunda abordagem teórica para compreender o neoliberalismo tem raízes no pensamento de Michel Foucault. Em "Nascimento da Biopolítica"38, o autor constrói uma genealogia daquilo que considera uma "nova definição do liberalismo, da arte liberal de governar" (FOUCAULT, 2008, p. 142). O objetivo de Foucault é propor, por meio da noção de neoliberalismo, que a governamentalidade ${ }^{39}$ liberal transformou-se, ao longo do século XX, em uma governamentalidade essencialmente diferente. Nas palavras do autor,

“ [...] o neoliberalismo atual não é, de maneira nenhuma [...], a ressurgência, a recorrência de velhas formas de economia liberal, formuladas nos séculos XVIII e

\footnotetext{
${ }^{38}$ Curso dado por Foucault no Collège de France, entre 1978 e 1979.

${ }^{39}$ A noção foucaultiana de governamentalidade aponta para a arte de gestão das populações e dos indivíduos. Ao mesmo tempo em que a governamentalidade se impõe exteriormente ao indivíduo por meio de técnicas, práticas e discursos, uma dimensão fundamental do conceito envolve sua internalização em autogoverno pelos próprios sujeitos (BROWN, 2015, pp.117-118).
} 
XIX, que o capitalismo reativaria, por certo número de razões, relacionadas tanto à sua impotência, às crises que ele atravessa, quanto a certo número de objetivos políticos ou mais ou menos locais e determinados" (FOUCAULT, 2008, p. 159).

Do ponto de vista da construção intelectual do neoliberalismo, ao longo do século XX, alguns deslocamentos em relação ao liberalismo clássico são particularmente importantes deslocamentos cujas consequências são centrais quando o fenômeno neoliberal é compreendido como uma governamentalidade. Em primeiro lugar, ao passo que, nas leituras clássicas, o princípio definidor e organizador do mercado era a troca - e, consequentemente, a equivalência entre os agentes econômicos - isso se altera no neoliberalismo. Neste, a concorrência é alçada à posição de princípio central, regulador do mercado e garantidor da racionalidade econômica. Como consequência, a equivalência dá lugar à desigualdade como característica central, efeito de um mercado que se define pela concorrência entre os agentes nele inseridos (FOUCAULT, 2008, pp. 160-164).

Em segundo lugar, diferentemente do que ocorria no liberalismo clássico, a concorrência deixa de ser compreendida, pelos autores neoliberais, como um fenômeno natural: embora seus efeitos sejam benéficos à economia de mercado, este princípio crucial depende de uma construção ativa. Dessa mudança de estatuto da concorrência, decorre uma transformação importante também em relação a qual deve ser a função do Estado, um terceiro deslocamento em relação ao liberalismo clássico. Neste, a relação entre a economia e o Estado era de “delimitação recíproca de áreas diferentes" (FOUCAULT, 2008, p. 164), cabendo ao Estado deixar o mercado "livre" para que a concorrência, naturalmente, o regule. No neoliberalismo, isso muda: uma vez que o princípio da concorrência só pode florescer "sob certo número de condições cuidadosa e artificialmente preparadas" (FOUCAULT, 2008, p. 164), cabe ao Estado garantir que este princípio seja implantado, incentivado e resguardado.

Assim, pode-se dizer que, no neoliberalismo, o Estado é "economizado" (BROWN, 2015, p.64), ou seja, seu objetivo não é mais o "deixar fazer", mas sim, essencialmente, a promoção e construção ativas do mercado concorrencial. A concorrência torna-se, por consequência, o principal foco da ação pública (DARDOT; LAVAL, 2016, p.303). Mais do que um objetivo de política, no entanto, o Estado neoliberal passa a encontrar no mercado e na concorrência suas próprias fontes de legitimidade, ou seja, a própria justificativa para sua existência. O mercado se torna o gabarito contra o qual o Estado deve ser conferido, o critério básico a partir do qual as atividades estatais devem ser julgadas e declaradas (i)legítimas. Emerge, portanto, um Estado submisso ao mercado, delimitado, definido e legitimado por ele 
(BROWN, 2015, p.64). Como será discutido no primeiro capítulo, a mobilização do conceito de "governança" - também em ascensão na última década do século XX -, juntamente com novas noções, como a de "melhores práticas" na ação pública, serão elementos importantes dessa transformação neoliberal operada sobre as estruturas e práticas estatais (BROWN, 2015, pp.122-131; DARDOT; LAVAL, 2016, pp.311-312; pp.379-380).

Um quarto deslocamento intelectual realizado pelo neoliberalismo foi $o$ desenvolvimento de uma teoria do capital humano ${ }^{40}$, a partir da qual foi possível reelaborar o problema do trabalho enquanto categoria teórica do discurso econômico (FOUCAULT, 2008, p.303). De forma simplificada, concepções neoliberais argumentam que o trabalho teria sempre sido abordado, nas análises econômicas, de maneira marcadamente abstrata, sem que "suas modulações qualitativas e os efeitos econômicos dessas modulações [...]" (FOUCAULT, 2008, pp. 305-306) fossem levados em consideração. O trabalho, em sua natureza qualitativa, teria sido "neutralizado" pela análise econômica do liberalismo clássico, que o teria reduzido a um único fator quantificável: o tempo. Se o trabalho não pode ser abstratamente reduzido à "força de trabalho" decomposta no tempo, tampouco o salário pode ser compreendido como o custo desta mesma força por uma quantidade de tempo. Assim, o salário passa a ser visto como uma "renda" que decorre do trabalho feito pelo trabalhador, o qual, por sua vez, passa a ser compreendido como o capital gerador dessa renda. Realiza-se, assim, um importante deslocamento epistemológico neoliberal, sublinhado por Foucault: se, antes, a ciência econômica era considerada, grosso modo, a ciência dos processos e dos mecanismos de produção, troca e consumo, agora sua função central se torna compreender como os indivíduos, entendidos como capital humano, alocam este capital (necessariamente limitado) diante de fins alternativos.

A conversão da categoria trabalho na noção de capital humano tem, previsivelmente, profundas consequências. Transformando a ciência econômica numa análise da racionalidade econômica individual, o neoliberalismo buscará definir qual é a atividade básica deste novo trabalhador, agora concebido como "capital de si". Nesse sentido, se o trabalhador do liberalismo clássico era definido essencialmente por sua atividade de "produção", agora o comportamento típico do indivíduo sob o neoliberalismo será o "empreendedorismo", esta capacidade de prospecção de, e investimento em boas oportunidades. Pode-se começar a perceber, a partir destes deslocamentos, como o neoliberalismo pode ser compreendido como

\footnotetext{
${ }^{40}$ Promovida sobretudo pelos americanos da Escola de Chicago (FOUCAULT, 2008, p.303).
} 
uma governamentalidade ou uma racionalidade e, por consequência, quais são seus efeitos sobre o governo dos indivíduos. O objetivo de Foucault é apontar como esta nova forma de governo que é o neoliberalismo se torna, também e sobretudo, um modelo de autogoverno. Em outras palavras, trata-se de decifrar os efeitos, em termos de comportamento dos indivíduos, que a interiorização das lógicas neoliberais produz sobre as racionalidades; de compreender, em suma, a nova subjetividade que passa a ser prototipicamente produzida com a ascensão do neoliberalismo. Mais do que uma análise exclusiva sobre o autogoverno dos indivíduos, contudo, trata-se de apontar também, e centralmente, para as transformações nas práticas estatais e sociais que o neoliberalismo traz à tona. Em outras palavras, não apenas o indivíduo é transformado em "empreendedor de si”, com a internalização de um novo modelo de racionalidade, mas também as estruturas estatais e as organizações da própria sociedade passam, progressivamente, a incorporar um modelo neoliberal de atuação.

\section{Sínteses e ampliações: neoliberalismo despolitizante em contexto colonial}

A abordagem de Foucault tem sido, mais recentemente, retomada e ampliada por autoras e autores que buscaram, a partir da noção de neoliberalismo enquanto governamentalidade - e em diálogo (por vezes tenso) com a perspectiva marxista -, analisar a generalização da racionalidade neoliberal e seus efeitos para a esfera política da vida social. Entre os principais exemplos estão Pierre Dardot, Christian Laval, Wendy Brown e Verónica Gago, cujas obras buscam demonstrar a progressiva constituição de um novo modelo de "conduta das condutas", ou seja, de governo dos indivíduos a partir de suas próprias condutas, determinadas e direcionadas por novos dispositivos ${ }^{41}$ que seriam tipicamente neoliberais. Embora seja fundamental a reconstrução histórica que Dardot e Laval (2016) promovem do surgimento do neoliberalismo - tanto sua ascensão em meios intelectuais ${ }^{42}$ quanto sua progressiva

\footnotetext{
${ }^{41}$ Sobre o conceito de dispositivo, Foucault certa vez o definiu como "um conjunto absolutamente heterogêneo que implica discursos, instituições, estruturas arquitetônicas, decisões regulamentares, leis, medidas administrativas, enunciados científicos, proposições filosóficas, morais e filantrópicas, em resumo: tanto o dito como o não dito, eis os elementos do dispositivo. O dispositivo é a rede que se estabelece entre esses elementos. [...] O dispositivo tem uma função eminentemente estratégica. [...] Trata de uma certa manipulação de relações de força, de uma intervenção racional e combinada das relações de força, seja para desenvolvê-las em certa direção, seja para bloqueá-las, ou para estabiliza-las, ou utiliza-las" (FOUCAULT, 2001, pp.299-300).

${ }^{42}$ No que tange à ascensão do neoliberalismo enquanto corrente intelectual, Dardot e Laval retornam até a década de 1930, mostrando como, antes da formação da Sociedade Mont Pelerin (citada por David Harvey como principal fonte intelectual do neoliberalismo, nos anos 1950), já existia um esforço intelectual efetivo de refundação do liberalismo. O Colóquio Walter Lippman de 1938, apesar de sua grande heterogeneidade interna, é apontado como exemplo deste esforço de reinvenção liberal, diante da grave crise vivida pelo liberalismo na década de 1930 (DARDOT; LAVAL, 2016).
} 
concretização em arranjos políticos concretos - o objetivo central dos autores franceses é expor os efeitos do neoliberalismo em termos de (auto) governo das vidas e de transformação da ação pública. Nas últimas décadas, a desregulamentação progressiva das relações econômicas e a construção cada vez mais intensa de situações de concorrência, em dimensões a priori não econômicas, tiveram para Dardot e Laval (2016) importantes efeitos sobre as condutas individuais, na medida em que tais modelos de conduta e de relação social foram incorporados pelos indivíduos em seus próprios cálculos quotidianos. A financeirização (desregulada) do capitalismo, por exemplo, impulsionou a interiorização pelas empresas das taxas de lucro exigidas pelos acionistas, exigências estas que foram repassadas aos assalariados. O trabalhador deve, assim, incorporar em seu trabalho o padrão de valorização exigido pela concorrência financeira mundial e tornar-se, ele mesmo, um "centro de lucro individual" responsável por sua valorização (DARDOT; LAVAL, 2016, p. 226).

Essa construção de um novo sujeito de conduta empresarial opera uma transferência de responsabilidades ao indivíduo, uma retirada de direitos anteriormente garantidos ao mesmo. $\mathrm{O}$ indivíduo passa a ser considerado o único responsável por seu desempenho - por seu sucesso e, naturalmente, por seu fracasso. A prospecção de boas oportunidades e sobretudo a gestão dos riscos envolvidos em sua atividade profissional (mas também em sua vida de forma geral: o risco de ficar doente, por exemplo) progressivamente deixam de ser responsabilidades de um Estado social, sendo entregues ao setor privado que, por sua vez, transforma a gestão do risco em serviços comerciais altamente individualizados (DARDOT; LAVAL, p.346-350). Entregase, por exemplo, a responsabilidade pelo desemprego ao desempregado, pela educação, ao estudante, pela saúde, ao doente, a responsabilidade pela pobreza, ao pobre, que não soube localizar as oportunidades de empreendimento e comportar-se de acordo. Nessa nova sociedade, concebida como uma empresa feita de empresas, é duramente criticada a dependência em relação a redes sociais de apoio e formas coletivas de garantir a existência (BROWN, 2015, pp. 132-133). O novo sujeito neoliberal internaliza os ditames da concorrência, da autovalorização, da responsabilidade por si e do desempenho constantes, passando a reproduzi-los em (potencialmente) todos os âmbitos de sua vida ${ }^{43}$. Surge, assim, um indivíduo cuja subjetividade é progressivamente homogeneizada em torno dos princípios do mercado concorrencial (DARDOT; LAVAL, 2016; BROWN, 2015).

\footnotetext{
${ }^{43}$ Uma série de técnicas e conhecimentos surgem, nesse sentido, buscando o aprimoramento individual, a maximização da eficácia comportamental, dentre as quais Dardot e Laval (2016, p.339) destacam o coaching, a programação neurolinguística e a análise transacional.
} 
Autoras como Verónica Gago (2018) e Wendy Brown (2015) têm buscado enfatizar, a partir das leituras acima, uma compreensão sobre o neoliberalismo a partir de suas “aterrissagens" (GAGO, 2018, p.8) e combinações locais, complexificando o que, à primeira vista, poderia parecer um funcionamento muito totalizante do fenômeno - tanto quando compreendido como um sistema global quanto quando concebido como uma racionalidade que se globaliza. Gago (2018, p.24), por exemplo, propõe "uma leitura dupla de Foucault a partir de Marx", sugerindo duas "topologias" para estruturar uma análise do neoliberalismo. Por um lado, "de cima para baixo" (GAGO, 2018, p.17, itálico no original), o neoliberalismo expressa "uma modificação do regime de acumulação global” (GAGO, 2018, p.17), resultante de "novas estratégias de corporações, agências e governos" (GAGO, 2018, p.17). A neoliberalização progressiva de diferentes partes do mundo, assim, não deixa de ser compreendida em Gago como o avanço de um projeto de intensificação da exploração capitalista. Mas, por outro lado, a autora também coloca no centro de sua análise uma topologia "de baixo para cima" (GAGO, 2018, p.17, itálico no original): o neoliberalismo é também - e centralmente - um novo conjunto de "modos de vida" (GAGO, 2018, p.17), a ascensão e proliferação de novas "subjetividades e táticas da vida cotidiana" (GAGO, 2018, p.16), novos "modos de fazer, sentir e pensar que organizam os cálculos e os afetos da maquinaria social" (GAGO, 2018, p.16).

Contudo, apontar para uma dimensão "imanente" 44 do neoliberalismo não significa afirmar uma colonização completa das racionalidades por uma abstrata razão neoliberal. Ao contrário, trata-se, em Gago, de observar como essa nova racionalidade opera "combinando-se de forma inovadora com outras racionalidades" (GAGO, 2018, pp.22-23), como ela se encontra - de maneira tensa - com saberes, modos de vida e realidades locais, e como é negociado seu enraizamento nesses mesmos saberes, realidades e modos de vida. É esse "traço polimórfico" (GAGO, 2018, p.26) do neoliberalismo, essa sua atuação concomitante em diferentes níveis, que faz com que suas manifestações estejam longe de refletir a imposição direta e linear de um projeto homogêneo. A ênfase, aqui, deve estar nos dispositivos e mediações que realizam a "imanentização" (GAGO, 2018, p.17) das lógicas neoliberais, gerando o neoliberalismo como um fenômeno cujas manifestações são eminentemente plurais (GAGO, 2018, p.26). Essa pluralidade é um dos motivos que justificam a relativa flexibilidade de Verónica Gago ao unir as perspectivas marxista e foucaultiana, apesar das diferenças epistemológicas entre elas ${ }^{45}$.

\footnotetext{
${ }^{44}$ Para evitar explicações excessivamente transcendentes do neoliberalismo - que o consideram unicamente um projeto imposto de cima - Gago (2018, p.17) sublinha que o fenômeno deve ser compreendido como "uma forma avançada e sofisticada de imanentização da transcendência".

${ }^{45}$ Ver, por exemplo, Dardot e Laval (2016, pp.397-398) e Brown (2015, pp.74-77).
} 
Segundo a autora, o caráter necessariamente heterogêneo do fenômeno exige, para uma análise adequada de suas "aterrissagens e ensamblagens com situações concretas" (GAGO, 2018, p.8), não amplas estruturas teóricas, mas sim "enunciados contextualizados" (GAGO, 2018, p.26), "uma determinada cartografia política" (GAGO, 2018, p.26) com conceitos capazes de apreender não apenas as dimensões globais do neoliberalismo, mas também a contingência de suas manifestações.

Em sua análise sobre os efeitos da ascensão neoliberal para os regimes democráticos, Wendy Brown (2015) também navega entre as concepções marxista e foucaultiana. Sem abandonar um entendimento do neoliberalismo enquanto fenômeno sistêmico - uma vez que não pode ser compreendido fora do capitalismo ou sem referência a ele ${ }^{46}$ (BROWN, 2015, pp.74-77) -, a autora se aproxima de Gago ao enfatizar a "plasticidade e inconstância" (BROWN, 2015, p.21) do fenômeno neoliberal. Para Brown, são inegáveis a nova ordem de razão representada pelo neoliberalismo e seus efeitos sobre as subjetividades. Contudo, uma análise atenta ao contexto e às manifestações localmente específicas do conceito continua sendo imprescindível: o neoliberalismo "é globalmente onipresente, mas ainda assim desunificado e não idêntico a si mesmo, no espaço e ao longo do tempo" (BROWN, 2015, p.21).

Apesar da diversidade atribuída ao fenômeno, a análise de Brown enfatiza uma operação - de particular importância para essa pesquisa - tipicamente associada a processos de expansão e enraizamento neoliberais: a despolitização. A transformação neoliberal do Estado, da sociedade e do indivíduo tem, como um de seus efeitos, a subsunção a lógicas econômicas de dimensões até então compreendidas como eminentemente políticas. No que tange ao Estado, as políticas de governo passam a ser apresentadas como eminentemente técnicas, fruto da aplicação de um conhecimento objetivo e, portanto, politicamente neutras. Em sintonia com tais mudanças, emerge uma nova gramática, vinda sobretudo da administração privada, para caracterizar a gestão pública e descarrega-la de sua dimensão propriamente política: como mencionado anteriormente, consolidam-se noções como "boa governança", "melhores práticas" e benchmarking (BROWN, 2015, pp. 135-142; DARDOT; LAVAL, 2016, pp.311312). No caso da sociedade e do indivíduo, práticas sociais e políticas reconfiguram-se, também, em direção a uma lógica técnica e profissionalizada - por exemplo, por meio da transformação de movimentos sociais em organizações não governamentais (JALALI, 2013).

\footnotetext{
${ }^{46}$ E este, por sua vez, não pode ser compreendido unicamente como uma ordem de razão: o capitalismo possui efeitos de dominação concretos que, embora envolvam a produção e circulação de verdades, de lógicas de (auto)governo, não se reduzem a estas. Em outros termos, Wendy Brown se recusa a abandonar uma dimensão irredutivelmente material e sistêmica do neoliberalismo.
} 
Como resultado, fenômenos e problemas de natureza política perdem saliência aparente, sendo progressivamente apresentados como problemas organizacionais ou de gestão. Nesse sentido, Wendy Brown (2015) argumenta que, para um regime democrático, o esvaziamento neoliberal da política só pode trazer efeitos negativos, na medida em que enfraquece as práticas políticas das quais depende a própria democracia. Nessa dissertação, argumenta-se que uma linha de interpretação semelhante pode ser seguida para abordar a neoliberalização em contextos coloniais. Na medida em que a descolonização é fruto de um processo eminentemente político de resistência (FANON, 1968), as transformações neoliberais têm como consequência necessária, nas sociedades submetidas a processos de dominação colonial, o enfraquecimento das capacidades políticas de luta contra as estruturas coloniais (ainda) predominantes.

Em outros termos, o neoliberalismo associa-se de forma sinérgica a estruturas coloniais, e seu enraizamento em realidades marcadas pela colonização não deve ser visto como anomalia. Apesar da ênfase neoliberal em participação, accountability e empoderamento, por exemplo parte da gramática neoliberal de governo mencionada acima, que será analisada no primeiro e terceiro capítulos -, não há motivos para supor que as transformações neoliberais não sejam impulsionadas em realidades coloniais. Pelo contrário, o sistema capitalista em geral, em sua expansão e consolidação ao longo dos séculos, nunca deixou de se associar ao colonialismo, incorporando-o como parte central de seu funcionamento e, ao mesmo tempo, reforçando-o.

O capitalismo, enquanto sistema de acumulação, não se vale unicamente da exploração econômica para se expandir - isto é, para acumular. Em diálogo com Marx e Rosa Luxemburgo, David Harvey (2004, p.115) sugere, nesse sentido, duas dimensões da acumulação capitalista. Por um lado, a dominação mais puramente econômica, de extração de mais valia do trabalho assalariado. Por outro, contudo, também constituem parte integrante do sistema capitalista, em sua trajetória histórica, meios não econômicos - políticos, jurídicos, militares, coloniais - para garantir a exploração econômica e consequente acumulação. Partindo da leitura feita por Marx sobre a "acumulação primitiva", Luxemburgo e Harvey (2004) indicam a contínua necessidade do capitalismo de "colonizar" partes do mundo e esferas da vida social anteriormente organizadas a partir de outras lógicas, liberando ativos - força de trabalho, recursos naturais, e assim por diante - de baixo valor para que o capital possa ser investido. Para realizar essa “espoliação" - essa exploração econômica por meios não econômicos -, as classes capitalistas frequentemente contaram com o apoio (político e militar) do Estado. Harvey (2004, p.121) oferece uma série de exemplos de como as práticas englobadas por Marx, em sua concepção da 
acumulação primitiva, permanecem extremamente presentes no funcionalismo do capitalismo contemporâneo:

Todas as características da acumulação primitiva que Marx menciona permanecem fortemente presentes na geografia histórica do capitalismo até os nossos dias. A expulsão de populações camponesas e a formação de um proletariado sem-terra tem se acelerado em países como o México e a Índia nas três últimas décadas; muitos recursos antes partilhados, como a água, têm sido privatizados (com frequência por insistência do Banco Mundial) e inseridos na lógica capitalista da acumulação; formas alternativas (autóctones e mesmo, no caso dos Estados Unidos, mercadorias de fabricação caseira) de produção e consumo têm sido suprimidas. Indústrias nacionalizadas têm sido privatizadas. O agronegócio substituiu a agropecuária familiar. E a escravidão não desapareceu (particularmente no comércio sexual).

Afirmar a acumulação por espoliação como dimensão inerente do sistema capitalista, ao mesmo tempo compreendendo o neoliberalismo como intensificação desse sistema, leva à conclusão de que, sob a ofensiva de classe neoliberal, também a acumulação por espoliação se intensifica (HARVEY, 2004; 2008). É nesse sentido que parte central da agenda neoliberal envolve a privatização de ativos e serviços públicos, bem como de recursos naturais, a "modernização" de formas de produção tradicionais e - particularmente importante para essa pesquisa - a colonização, a expropriação colonial do território e a dominação colonial de suas populações. A dominação e espoliação coloniais, assim, devem ser vistas como parte inerente da exploração capitalista - ao mesmo tempo estruturante dela e estruturada por ela -, e o neoliberalismo, como intensificação generalizada da espoliação capitalista, deve antes repor estruturas de colonização que combatê-las. A exploração econômica a partir de estruturas coloniais insere-se, em suma, num regime de acumulação global: longe de ser uma exceção, a articulação entre o neoliberalismo e estruturas e práticas coloniais expressa a dependência capitalista em relação a formas não econômicas de exploração. Sob o neoliberalismo, portanto, a necessidade de impulsionar a acumulação capitalista implica, para realidades marcadas por estruturas e práticas coloniais, uma intensificação de tais estruturas e práticas, ou uma reestruturação destas com fins de maximização do ganho econômico.

Diferentes autores buscaram analisar como a ascensão do neoliberalismo ocorreu de maneiras específicas em contextos marcados por dominação colonial recente - e, em muitos casos, ainda presente. No que tange ao continente africano, por exemplo, James Ferguson (1994) analisou os efeitos da intervenção do Banco Mundial em Lesoto, enfatizando os discursos, práticas e conhecimentos difundidos pela instituição na busca por atingir o “desenvolvimento" do país. Durante a consolidação do neoliberalismo como novo paradigma 
global, Ferguson apontou para a despolitização como consequência das novas práticas impulsionadas pelo Banco entre as populações locais. Mais recentemente, e num estudo menos localizado, o autor solidifica sua análise sobre os efeitos negativos trazidos ao continente pela nova "ordem mundial neoliberal" (FERGUSON, 2006). Assim como as autoras debatidas acima, Ferguson também confere ao neoliberalismo uma natureza sistêmica, sem que isso signifique, contudo, ignorar os dispositivos variados pelos quais ele é difundido nos países da África. Nesse sentido, sua obra é frequentemente utilizada para analisar a mobilização, em contextos coloniais, de um discurso neoliberal sobre o "desenvolvimento" (HADDAD, 2016), bem como os resultados sociais e (anti)políticos de tal mobilização.

No debate sobre a neoliberalização em países do continente africano, Graham Harrison (2004; 2005; 2010) também destaca o papel cumprido pelo Banco Mundial. Para abordar o neoliberalismo, o autor evita descartar as abordagens discutidas acima. Partindo de uma perspectiva interpretativa, Harrison define o conceito como um conjunto de práticas sociais que, de forma agregada, compõem um projeto de "engenharia social" (HARRISON, 2010) e “política” (HARRISON, 2004, p.5), que avança (também) sobre países africanos. É sobretudo enquanto projeto global de transformação, assim, que o neoliberalismo deve ser compreendido para o autor: a neoliberalização não é somente um processo de reforma econômica, mas fundamentalmente uma reconfiguração programada do Estado, da sociedade e da relação entre ambos (HARRISON, 2010, p.32). Como tal - e de forma semelhante à literatura discutida até aqui -, o neoliberalismo está relacionado à difusão de novos modelos de sociabilidade, de novas “identidades sociais” (HARRISON, 2010, p.32) afinadas ao ideal do indivíduo racional.

Partindo das perspectivas discutidas até aqui, seguimos Graham Harrison ao compreender o neoliberalismo - aqui analisado sobretudo nas intervenções financiadas pela assistência externa à Palestina ocupada - como um projeto holístico de engenharia social, política e econômica, um conjunto de práticas mais ou menos articuladas, visando remodelar economias, sociedades e Estados em uma certa direção, mais ou menos bem definida. O neoliberalismo não deixa, aqui, de ser um projeto para expandir a atividade capitalista - como será visto nos dois primeiros capítulos, essa foi uma dimensão importante da neoliberalização dos territórios palestinos -, mas ele é mais que isso. $\mathrm{O}$ projeto neoliberal impulsiona transformações nas formas de organização e práticas de associação predominantes na vida social. Harrison e Ferguson são particularmente importantes para essa análise, na medida em que analisaram o Banco Mundial como um vetor importante deste projeto neoliberal em contextos como o do continente africano, em que - como no caso palestino - estavam (e ainda 
estão) colocados tanto o imperativo de construção das estruturas estatais quanto a continuidade de estruturas coloniais operantes. Harrison (2004) aponta, por exemplo, a centralidade da governança como instrumento conceitual mobilizado para, efetivamente, construir Estados a partir das "melhores práticas" internacionais - o que o autor denomina "Estados governança", resultantes de anos de intervenção sistemática de instituições como o Banco Mundial. Ferguson (1994), por sua vez, enfatiza os efeitos de despolitização trazidos pelo Banco Mundial por meio de projetos de modernização econômica: as transformações impulsionadas localmente têm suas dimensões e efeitos políticos sistematicamente ocultados em prol de uma linguagem técnica e homogênea, que concebe o desenvolvimento como um processo linear de expansão da atividade capitalista - da produção assalariada para o comércio, de preferência internacional. Transformam-se, assim, uma série de práticas locais, modos de vida e de (re)produção da existência, assim como práticas da ação pública, seguindo como modelo os padrões neoliberais do livre mercado, da concorrência internacional e da boa governança prescritos pelo Banco Mundial.

Ao longo dos próximos capítulos, busca-se dialogar com as reflexões expostas acima e aprofunda-las - sobre o neoliberalismo, suas contingências e os dispositivos de que ele se utiliza, a gramática política que ele coloca em circulação e os efeitos despolitizantes, tanto dessa gramática quanto das intervenções concretas que ela embasa. Sobretudo, busca-se observar a “aterrissagem" (GAGO, 2018, p.8) do modelo neoliberal numa realidade marcada pelo colonialismo de povoamento (WOLFE, 2006), apontando as consequências desse neoliberalismo colonial para a dominação das populações palestinas dos TPO e para suas perspectivas de resistência anticolonial. Assim como o neoliberalismo, o colonialismo possui uma natureza dual - ele é exploração, despossessão, mas também tem uma dimensão construtiva, de modernização e desenvolvimento da sociedade colonizada (desenvolvimento este sempre submetido, evidentemente, aos objetivos estratégicos coloniais). Ele mobiliza estratégias de sofisticação, busca construir para melhor dominar. É nesse sentido que o colonial se articula ao neoliberal, e reproduz dominação. Portanto, na análise feita sobre as intervenções de assistência externa aos palestinos dos TPO, a partir dos anos 1990 e sob o escopo dos “processos de paz”, essa dissertação afirma uma compreensão das práticas neoliberais de assistência financeira internacional (também) como práticas coloniais, na medida em que repõem e reforçam efeitos da dominação colonial israelense e, como será argumentado no terceiro capítulo, na medida em que minam as capacidades sociais e políticas dos palestinos dos TPO de resistir a essa dominação (TURNER, 2012, p.494). 


\section{Estrutura da Dissertação}

Nos próximos três capítulos, analisa-se a assistência financeira internacional como um dos vetores centrais do projeto de neoliberalização da Cisjordânia e da Faixa de Gaza, posto em andamento a partir dos “processos de paz”. Como afirmado, o recorte será sobretudo na atuação do Banco Mundial, embora também sejam realizadas análises sobre a participação de atores como a USAID - particularmente importante nas transformações observadas, a partir dos anos 1990, nos modelos predominantes de organização da sociedade palestina dos territórios. O primeiro capítulo da dissertação faz uma análise do Banco Mundial como um agente da economia política internacional da segunda metade do século XX, localizando-o, no período estudado, como um vetor importante das transformações neoliberais a nível global. Em particular, analisa-se a primeira grande bateria de estudos realizados pelo Banco Mundial a respeito da problemática do desenvolvimento dos territórios palestinos ocupados, expondo a inserção de tais estudos nos "processos de paz" mais amplos. Sobretudo, busca-se identificar nos documentos analisados as principais posições e diretrizes do Banco no que tange à reorganização prescrita à economia dos TPO, enfatizando o enquadramento geral que a instituição fez sobre a questão palestina e os "processos de paz", e expondo o modelo de desenvolvimento socioeconômico recomendado para a Cisjordânia e a Faixa de Gaza. No segundo capítulo, continua-se a enfatizar as transformações econômicas impulsionadas pelo Banco Mundial nos TPO, agora através de um estudo de caso sobre a Zona Industrial de Gaza (ZIG) - iniciativa levada a cabo pela instituição, em conjunto com o grande empresariado palestino e a ANP. Pela análise da experiência da zona industrial operante em Gaza, entre 1997 e 2007, são destacados alguns efeitos que o modelo de desenvolvimento econômico incentivado pela assistência financeira internacional trouxe para uma realidade de ocupação colonial como a dos TPO. O terceiro capítulo, sem deixar de compreender o auxílio externo como um vetor central das transformações analisadas, observa a neoliberalização por ele impulsionada como um processo que, como discutido, reverbera "de baixo para cima", reestruturando as práticas locais palestinas de organização e ação social. Em particular, são estudados projetos para organizações não governamentais e para a "sociedade civil palestina" dos TPO, levados a cabo pelo Banco Mundial e pela USAID a partir do contexto dos "processos de paz". Busca-se, aqui, ressaltar as transformações impulsionadas no nível das práticas associativas da sociedade palestina sob ocupação, tecendo reflexões sobre os efeitos dessas transformações para estratégias e horizontes políticos de resistência ao projeto colonial israelense. Ao longo dos três capítulos, relatórios de projetos de desenvolvimento realizados pelo Banco nos TPO - 
disponíveis no website da instituição - compõem a grande maioria dos documentos primários aqui estudados. Por meio da análise desses materiais, busca-se identificar os dispositivos difundidos pela assistência financeira externa no contexto estudado. Prescrições sobre reformas econômicas desejáveis e sobre a extensão do "setor público" palestino; determinação de diretrizes para iniciativas específicas - como as zonas industriais para exportação; critérios de processos seletivos para prover financiamento a ONGs palestinas dos TPO: estas e outras condições, impostas pela assistência internacional aos palestinos sob ocupação, são aqui compreendidas como dispositivos que, como tais, visam manipular as relações de forças locais numa direção específica (FOUCAULT, 2001, pp.299-300). Em outras palavras, trata-se de, ao rastrear os dispositivos impulsionados por vetores como o Banco Mundial e a USAID, identificar o objetivo estratégico aos quais eles contribuem, isto é, o horizonte de transformação/continuidade ao qual servem tais dispositivos. Após a análise empírica realizada nos três capítulos, conclui-se a dissertação com uma discussão sobre estratégias alternativas para o desenvolvimento - econômico, mas também social e político - do povo palestino sob ocupação. Busca-se, aqui, dialogar com concepções que colocam no centro, como ponto de partida para pensar qualquer desenvolvimento palestino possível, a condição dessa sociedade de submissão contínua a um projeto colonial de povoamento e, portanto, a necessidade de resistência a esse projeto. 


\section{CAPÍTULO 1: "UM INVESTIMENTO NA PAZ": O BANCO MUNDIAL NOS TERRITÓRIOS PALESTINOS OCUPADOS}

\subsection{O Banco Mundial e a assistência internacional aos "processos de paz"}

Embora programas de assistência externa existissem na Cisjordânia e na Faixa de Gaza desde os anos 1970, após a ocupação, a ausência de coordenação entre os financiadores e a inexistência de uma autoridade palestina centralizada tornam bastante escassos os dados agregados sobre estas práticas de assistência. De forma geral, a principal fonte de assistência aos palestinos dos territórios era a United Nations Relief and Works Agency (UNRWA), agência da ONU responsável pela gestão dos campos de refugiados palestinos há décadas, que continuou a atuar nos campos da Cisjordânia e Faixa de Gaza após a ocupação de 1967 e contava com uma ampla presença nos territórios. No que tange à assistência financeira bilateral ou multilateral, dois conjuntos de doadores se destacavam: de um lado, governos de países árabes, sobretudo do Golfo, além da própria Organização para a Libertação da Palestina e dos partidos que a compunham; de outro, governos de países membros da OCDE, sobretudo europeus e EUA, além de organizações multilaterais como a União Europeia (BRYNEN, 2000, pp.44-48). Nas décadas que antecederam aos "processos de paz", o auxílio externo havia sido destinado sobretudo para educação e saúde e, em geral, canalizado por meio de organizações não governamentais locais e internacionais - na ausência de uma autoridade palestina e diante da indisposição da comunidade de assistência externa em canalizar estes valores por meio da Administração Civil da ocupação (BRYNEN, 2000, pp. 44-45).

Diante da perspectiva de "processos de paz" com Israel e do estabelecimento de uma autoridade palestina, enfraqueceu-se o receio da comunidade de assistência externa em ter sua ajuda aos TPO percebida como subsídio à ocupação de Israel (HEVER, 2010, pp.21-23), e um novo ímpeto de assistência financeira internacional passou a ser observado em apoio aos acordos de Oslo. Nesse contexto, dois se tornaram os principais objetivos declarados pelos principais doadores da comunidade internacional: melhorar a qualidade de vida imediata das populações palestinas - cujas condições socioeconômicas eram então bastante precárias ${ }^{47}$ - e garantir a construção institucional de uma entidade governamental autônoma palestina, com atuação em áreas A e B. O primeiro objetivo visava construir e consolidar, nas populações

\footnotetext{
${ }^{47}$ Como discutido brevemente na introdução, a expulsão de centenas de milhares de palestinos dos países do Golfo, bem como as políticas israelenses de fechamento das fronteiras e da livre circulação, cada vez mais presentes nos territórios palestinos, haviam causado aumentos nas taxas de desemprego e uma queda significativa na renda palestina (BANCO MUNDIAL, 1993a)
} 
palestinas locais, bases estáveis de apoio político aos "processos de paz" em andamento - em sintonia com o crescente consenso internacional neoliberal, descrito anteriormente, sobre as potencialidades da assistência externa como método de solucionar conflitos políticos (em muitos casos, coloniais). Buscava-se, com os programas de assistência internacional, garantir que os acordos políticos iniciados fossem acompanhados de "benefícios tangíveis" e rápidos, em termos econômicos, às populações palestinas da Cisjordânia e da Faixa de Gaza - benefícios que funcionariam como sustentação econômica aos processos políticos (BANCO MUNDIAL, UNSCO, 1999, p.8; BANCO MUNDIAL, 1994a, p.19). A busca por financiar projetos que garantissem ganhos materiais imediatos às populações palestinas expressava a visão, amplamente compartilhada pela comunidade doadora internacional, de que a melhoria das condições econômicas dos TPO era essencial para atingir a "paz" - sem tal melhoria, dificilmente seria possível manter o apoio dos palestinos à transição iniciada em Oslo. De forma simples, as populações palestinas dos territórios precisavam ganhar, e ganhar rápido, com as transformações trazidas pelos processos (BANCO MUNDIAL, 1994a, p. vii). Este objetivo pode ser notado nas palavras de Abdallah Bouhabib, então assessor do Banco Mundial e estreitamente envolvido com os esforços de ajuda aos TPO. Sobre o primeiro programa de assistência elaborado pelo Banco para os territórios, em 1994, Bouhabib (1994, p.66) afirma:

Eu devo dizer que este programa em particular possui um elemento político, na medida em que é particularmente importante neste caso que as pessoas vejam, bem cedo, que a situação delas vai melhorar por causa da paz.

Mais do que obter apoio popular ao processo de paz local, a comunidade internacional considerava que o acordo entre palestinos e israelenses era chave de um processo político maior, discutido anteriormente: a normalização das relações políticas e econômicas numa região historicamente marcada pelo conflito. Assim, a assistência financeira aos TPO tinha objetivos que ultrapassavam as transformações na Cisjordânia e em Gaza. Buscava-se

[...] ajudar os palestinos a atingir crescimento econômico sustentado e a desenvolver uma base econômica e sociopolítica saudável, que contribuiria para paz e estabilidade na região (BANCO MUNDIAL, UNSCO, 1999, p.8).

Paralelamente às melhorias de curto prazo nas condições de vida dos palestinos dos TPO - à produção de "dividendos de paz"48 que retroalimentariam positivamente os processos de Oslo -, o segundo grande objetivo da comunidade doadora internacional centrava-se na construção das estruturas governamentais da Autoridade Nacional Palestina (ANP)

\footnotetext{
48 A noção de "dividendos de paz" se tornou comum no vocabulário dos atores da comunidade internacional de assistência aos TPO, a partir do início dos “processos de paz” (HEVER, 2010, p.5).
} 
(BOUHABIB, 1994; HADDAD, 2016). Nesse ponto, a preocupação era estabelecer estruturas e dinâmicas governamentais saudáveis na futura entidade, a ser estabelecida como um dos resultados das negociações políticas. A tarefa exigia imensos esforços em termos de cooperação técnica, construção institucional e de capacidades. Para além de expressivos gastos iniciais inevitáveis numa construção deste tipo, a partir do zero -, a comunidade de assistência externa precisaria custear gastos recorrentes da ANP durante seus primeiros anos. De fato, era compreensão geral que a situação fiscal e orçamentária da autoridade demoraria a se estabilizar, e que tal estabilização dependeria crucialmente dos acordos futuros a serem obtidos com Israel. Buscava-se, nesse sentido, inserir desde o início nas estruturas da ANP as melhores práticas internacionais de gestão pública, pavimentando o caminho para que a autoridade se tornasse, o quanto antes, independente de assistência financeira internacional para continuar funcionando. Os objetivos de construção e reforma da ANP por atores como o Banco Mundial, analisados na terceira seção deste capítulo, expressam o papel que a assistência internacional teve em efetivamente moldar as estruturas políticas palestinas e os arranjos sociais e econômicos dos TPO - contribuindo localmente para esse amplo projeto de engenharia social e política neoliberal.

É importante ressaltar que as práticas e concepções da comunidade doadora internacional, no que tange ao desenvolvimento e à construção da "paz" nos territórios palestinos, não foram absolutamente homogêneas entre si. A diversidade de atores envolvidos - muitos representando seus respectivos governos nacionais - se expressou em diferentes ênfases e prioridades, e por vezes levou a atritos e descompassos entre doadores ${ }^{49}$. Apesar desta diversidade - e em parte devido a ela -, essa pesquisa analisa sobretudo a participação de um membro da comunidade de assistência externa: o Banco Mundial. Como ficará evidente ao longo da análise, o Banco teve papel central não apenas na coordenação entre os diferentes doadores - e, portanto, na gestão de eventuais discordâncias entre eles -, mas também, e sobretudo, na elaboração do enquadramento e das diretrizes a partir dos quais a comunidade internacional se engajou com a problemática do desenvolvimento da Cisjordânia e da Faixa de Gaza, a partir dos anos 1990. Assim, assume-se que a atuação do Banco Mundial nos TPO, embora não represente estritamente toda a comunidade doadora, determinou os parâmetros que

\footnotetext{
${ }^{49}$ Haddad (2016, pp.115-117) descreve, por exemplo, duas alas entre os doadores "ocidentais". Uma primeira, composta por países como EUA, Reino Unido e Alemanha, tendia a subordinar imperativos neoliberais de livre mercado e concorrência às demandas de segurança israelenses. Uma segunda ala era composta por países europeus menos alinhados a Israel - França, Portugal, Espanha, Itália, Suécia, entre outros -, e tendia a priorizar as iniciativas de desenvolvimento econômico e relativizar demandas israelenses excessivamente rígidas por segurança.
} 
guiaram a participação desta no esforço internacional de assistência financeira aqui analisado. No terceiro capítulo, como dito, amplia-se a análise para incluir a atuação de um segundo ator da comunidade de assistência externa no contexto dos "processos de paz", por meio do estudo de projetos da USAID para a "sociedade civil palestina" dos TPO.

Desde os primeiros meses de 1993, o Banco Mundial já havia dado início a estudos para avaliar as necessidades prioritárias dos territórios ocupados em termos de desenvolvimento. Atendendo a pedidos dos organizadores das conferências de paz dos anos anteriores, o Banco vinha atuando com o objetivo de levantar as informações necessárias e produzir um enquadramento de análise - que embasasse um futuro plano de ação - sobre os desafios para o desenvolvimento social, econômico e institucional dos TPO. O trabalho realizado pelo Banco Mundial serviria de base, ao longo dos anos seguintes, para o contato, sintonização e coordenação entre doadores; assim como para os esforços de arrecadação, elaboração de projetos específicos e canalização de financiamento para estes (BANCO MUNDIAL, 1993a, p.vii). Assim, o interesse renovado da comunidade de assistência internacional em financiar o desenvolvimento dos territórios palestinos, advindo da assinatura da Declaração de Princípios, deu-se num cenário em que já estava preparado um amplo enquadramento analítico - a partir do qual o desafio do desenvolvimento palestino poderia ser compreendido e enfrentado. Esse enquadramento analítico, e seus efeitos para a economia e sociedade palestinas dos TPO, são objetos desse capítulo.

Em 1993, com o início dos “processos de paz”, os financiadores externos solicitaram ao Banco Mundial auxílio técnico na gestão dos recursos de assistência e na elaboração dos projetos de desenvolvimento a serem financiados e implementados na Cisjordânia e na Faixa de Gaza, ao longo dos anos seguintes (BRYNEN, 2000, p.3). Desde então, como será exposto, o Banco se tornou ator central nos esforços concretos de assistência externa aos TPO, podendo efetivamente mobilizar as análises que haviam sido feitas nos estudos citados acima e, sobretudo, colocar em prática as diretrizes que haviam sido estabelecidas neles. A terceira seção deste capítulo analisa os estudos realizados pelo Banco em 1993. Antes disso, contudo, cumpre realizar uma breve descrição das estruturas estabelecidas - com o início dos "processos de paz" - para liderar e coordenar as iniciativas de assistência surgidas. Busca-se, especialmente, enfatizar a posição central que o Banco Mundial passou a ocupar dentro dessas estruturas. É o que se faz na próxima subseção. 


\subsubsection{As estruturas da assistência financeira internacional aos TPO}

É importante realizar uma descrição geral da arquitetura institucional estabelecida pela comunidade de assistência internacional nos TPO, a partir do início dos “processos de paz". A complexidade das estruturas postas em funcionamento, no início da década de 1990, deixa evidente a conexão entre os processos e um grande esforço internacional de auxílio financeiro aos palestinos. Não se busca, aqui, descrever as dezenas de países e organizações internacionais envolvidas no esforço em questão, mas traçar os principais componentes de uma arquitetura e uma dinâmica institucionais que foram importantes para os rumos tomados pelo “desenvolvimento" nos TPO desde Oslo. Busca-se, em particular, destacar a posição central ocupada pelo Banco Mundial nessa arquitetura.

Dentre os principais doadores engajados nos esforços de auxílio a partir dos "processos de paz”, destacam-se os Estados Unidos e a União Europeia, cujas contribuições foram canalizadas sobretudo pela USAID e pelo Banco de Investimento Europeu, respectivamente ${ }^{50}$. Além deles, historicamente, países vizinhos como a Arábia Saudita sempre representaram importantes fontes de ajuda financeira aos palestinos, padrão que se manteve após o início dos acordos. Instituições internacionais como o FMI, agências da ONU e o próprio Banco Mundial foram também atores centrais, como afirmado anteriormente (BRYNEN, 1996, pp. 47-8). Duas estruturas principais foram de início estabelecidas pela comunidade doadora internacional, após a assinatura da Declaração de Princípios em 1993. A primeira delas foi o Grupo Consultivo (GC), modalidade de instância tipicamente utilizada pelo Banco Mundial para coordenar fundos e ações, de governos e agências doadoras, destinados a um país específico (BOUHABIB, 1994, p. 65). O Grupo Consultivo, em geral (e também no caso palestino), é considerado um espaço mais técnico e procedimental, congregando especialistas dos países e agências doadoras. O GC criado no contexto do esforço de auxílio aos TPO era presidido por um representante do Banco Mundial, e teve sua primeira reunião em 16/12/1993, em Paris (BRYNEN, 2000, p.xxi).

A segunda estrutura estabelecida nesse contexto foi o Ad Hoc Liaison Committee ${ }^{51}$ (AHLC), significativamente menor e composto apenas pelos principais financiadores envolvidos no auxílio internacional aos territórios. O nível político dos representantes, em geral, era superior àquele dos membros do GC, sendo o AHLC considerado o responsável por

\footnotetext{
${ }^{50}$ Exemplo da participação desses dois atores foi a Zona Industrial de Gaza, que contou com financiamento de ambos (BANCO MUNDIAL, 1997b). A iniciativa é objeto de análise do próximo capítulo.

${ }^{51} \mathrm{O}$ Ad Hoc Liaison Committee era composto por Estados Unidos, União Europeia, Japão, Rússia, Canadá, Noruega e Arábia Saudita. Participavam, como membros associados, a Autoridade Palestina (após sua criação, em 1994), Israel, Egito, Jordânia e Tunísia, além da ONU (BRYNEN, 1996, pp. 48-49).
} 
estabelecer as diretrizes mais amplas do esforço de auxílio aos TPO - em outros termos, o órgão é a principal instância de deliberação e coordenação política da comunidade doadora nos TPO. O Banco Mundial atua como secretariado geral do comitê, o que - juntamente com sua função no Grupo Consultivo - dá a dimensão de sua centralidade, tanto técnica quanto política, no esforço internacional de auxílio aqui analisado (BRYNEN, 1996, pp. 48-50).

Os grandes volumes de ajuda, a serem despendidos em um período de tempo relativamente curto, colocavam à comunidade doadora internacional desafios poucas vezes enfrentados até então. Para além das duas instâncias citadas, outras subestruturas foram construídas nos anos que se seguiram à assinatura da DP, com o intuito de organizar e agilizar o processo de implementação do auxílio. No fim de 1994, o AHLC estabeleceu nos TPO um Comitê de Coordenação Local de Ajuda (CCLA) - copresidido por Noruega, EUA e pelo Banco Mundial. Com o objetivo de facilitar a coordenação local, "no chão", entre doadores e com a ANP, o CCLA se reunia com frequência maior (mensalmente) e contava com aproximadamente trinta representantes locais da comunidade doadora internacional e das outras instituições envolvidas. Por sua vez, o CCLA estabeleceu doze Grupos de Trabalho (GTs) setoriais, cada qual com um ministério da ANP como responsável, um doador como "padrinho" e uma agência internacional atuando como "secretariado". Os temas dos GTs envolviam agricultura; transporte e comunicações; serviço público/emprego; meio ambiente; saúde; turismo; e polícia. Além desses, quatro GTs tinham participação direta do Banco Mundial como secretariado ${ }^{52}$ : infraestrutura e moradia (com a Alemanha como "padrinho"); setor privado e comércio; finanças públicas (ambos com os EUA como "padrinho") e construção institucional e de capacidades (tendo como "padrinho" a União Europeia) (BRYNEN, 1996, p.49). Os quatro GTs com participação do Banco Mundial (e dos principais doadores, EUA e UE) expressam a importância relativa conferida a certos subprocessos (e, novamente, a relevância do Banco Mundial como administrador destes) dentro da transformação mais ampla, pretendida pela comunidade doadora nos TPO em nome do desenvolvimento. Como será abordado adiante, o protagonismo do setor privado, a liberalização do comércio e das finanças, bem como a construção de arquiteturas institucionais específicas no âmbito da ANP (o "setor público" palestino), eram considerados pelo Banco Mundial como aspectos centrais em sua agenda para o desenvolvimento dos territórios.

\footnotetext{
52 Nos GTs de infraestrutura/moradia e de construção institucional/de capacidades, a UNSCO atuou como cosecretariado ao lado do Banco Mundial. No GT de setor privado e comércio, a UNDP foi cosecretariado e, no GT de finanças públicas, o FMI cumpriu a função juntamente com o Banco (BRYNEN, 1996, p. 49).
} 
Juntamente com o CCLA, o Ad Hoc Liaison Committee estabeleceu também um segundo comitê, denominado Joint Liaison Committee (JLC) e formado pela Autoridade Palestina, por Israel, Estados Unidos, União Europeia, Banco Mundial, ONU e Noruega. O objetivo do comitê era funcionar como um espaço em que pudessem ser solucionados os obstáculos encontrados ao longo da implementação do auxílio - obstáculos estes geralmente criados pelas estruturas e práticas da ocupação israelense. Ademais, e de forma significativa, o JLC era a instância responsável por monitorar a implementação do Plano de Ação Tripartite sobre Receitas, Gastos e Financiamento dos Doadores para a AP ${ }^{53}$, assinado em 1995 pela ANP, Israel e a Noruega (como presidente do AHLC). O JLC, assim, visava entre outras coisas monitorar a performance fiscal da recém-criada ANP, sua arrecadação de impostos e situação orçamentária geral, bem como suas principais necessidades em termos de cooperação técnica e construção institucional (BRYNEN, 1996, pp. 50-51). Mais uma vez, o Banco encontra-se presente, ao lado dos principais atores envolvidos na assistência financeira aos TPO e nos "processos de paz" de forma geral.

Fica evidente, das breves descrições realizadas, a importância do Banco Mundial no esforço internacional por "desenvolver” a Palestina ocupada. A participação central do Banco nos comitês discutidos colocava a instituição na posição de principal coordenador entre os doadores, sendo assim facilitador da comunicação entre eles, principal responsável pelo angariamento de fundos e pela construção de pacotes concretos de assistência, por meio dos quais os recursos prometidos e levantados eram canalizados para projetos específicos de desenvolvimento. O primeiro desses pacotes - o Programa de Assistência Emergencial para os Territórios Ocupados - foi estruturado pelo Banco e apresentado à comunidade de doadores na primeira reunião do Grupo Consultivo, em dezembro de 1993, e estipulava a necessidade de US\$1,2 bilhões em auxílio para o período de 1994-96 - valor tido como condição para atender às necessidades prioritárias (identificadas pelo próprio Banco) dos TPO em termos de desenvolvimento. Outros pacotes de assistência foram organizados e administrados pelo Banco Mundial nesse contexto, como o "Programa de Reabilitação Emergencial", que totalizava quase US\$ 130 milhões em doações angariadas e empréstimos oferecidos pelo próprio Banco. Ademais, a instituição tornou-se responsável pela administração de fundos, financiados por doadores e voltados para projetos setoriais de desenvolvimento nos TPO. Dentre estes, destacam-se o Technical Assistance Trust Fund (TATF) e o Holst Fund, ambos criados para

\footnotetext{
${ }^{53}$ No original, "Tripartite Action Plan on Revenues, Expenditures and Donor Funding for the PA".
} 
financiar o estabelecimento e os custos iniciais das estruturas administrativas e folhas de pagamento da ANP (BANCO MUNDIAL, 1993a; BOUHABIB, 1994; BRYNEN, 1996, p.51).

Contudo, como afirmado acima, a importância do Banco Mundial no esforço internacional de auxílio aos TPO ultrapassou em muito a função de coordenação entre doadores, canalização de fundos ou assistência direta à implementação de projetos concretos. O Banco foi, antes de mais nada, um dos grandes responsáveis por formular os enquadramentos gerais a partir dos quais o desenvolvimento dos TPO deveria se dar. Como afirmado, a instituição foi a principal responsável, a partir da década de 1990, pela realização de pesquisas e produção de conhecimento voltado, especificamente, à problemática do desenvolvimento socioeconômico palestino. Assim, o Banco Mundial foi central para estabelecer os horizontes estratégicos possíveis e aqueles considerados inviáveis, os termos pelos quais o tema poderia ser pensado, discutido e operacionalizado, e também os termos nos quais, se considerava, não faria sentido pensar o desenvolvimento dos TPO. Em suma, será a partir de documentos produzidos pelo Banco que se consolidarão os entendimentos básicos nos quais se sustentou o esforço internacional de auxílio aos TPO. Foi o discurso produzido pela instituição que determinou as necessidades mais urgentes das populações palestinas em termos de financiamento externo, as prioridades setoriais dos projetos de assistência e, no limite, o próprio modelo de desenvolvimento econômico que os TPO deveriam seguir na esteira dos "processos de paz". Cumpre, portanto, realizar uma análise mais detida de como o Banco Mundial enquadrou a questão do desenvolvimento palestino no início da década de 1990. É o que se faz na terceira seção deste capítulo. Antes, contudo, é importante uma discussão mais detida sobre o próprio Banco Mundial, enquanto ator inserido numa certa economia política global e, argumenta-se, enquanto um dos vetores centrais do neoliberalismo, inclusive em contextos coloniais.

\subsection{O Banco Mundial como ator internacional}

A relevância que o Banco Mundial teve nos anos 1990, nas transformações levadas a cabo nos TPO, torna importante aqui uma análise mais detida da instituição como um ator internacional. Em outras palavras, é necessário explicitar uma "ontologia básica da agência do Banco" (HARRISON, 2004, p.5), localizando sua atuação no contexto analisado em uma compreensão anterior de suas características enquanto agente de uma economia política global específica (HARRISON, 2004). A partir de uma exposição dos diferentes momentos da instituição, assim, busca-se embasar uma caracterização do Banco Mundial como vetor internacional de certas ideias e práticas sobre desenvolvimento e governança (FERGUSON, 
1994; HARRISON, 2004; PEREIRA, 2014); como portador de um projeto liberal (WILLIAMS, 2008) e, a partir das últimas décadas do século XX, especificamente neoliberal (HARRISON, 2004).

Desde sua criação na década de 1940, o Banco Mundial passou por significativas transformações. Não se trata, aqui, de negá-las ou de apontar o Banco como uma instituição que se manteve fixa ao longo do tempo. No entanto, alguns valores, concepções e posições podem ser identificados como guias relativamente perenes de sua atuação ao longo das décadas, permitindo estabelecer uma caracterização básica da instituição enquanto agente localizado na história e desdobrar daí "a natureza de suas relações com outras estruturas e processos" (HARRISON, 2004, p. 8). Para construir essa caracterização, realiza-se nas próximas subseções uma breve recapitulação sobre o surgimento da instituição, sua evolução, transformações e permanências até a década de 1990, quando a atuação do Banco se tornou marcadamente presente nos territórios palestinos da Cisjordânia e da Faixa de Gaza.

\subsubsection{Primeiras décadas}

Após sua criação em 1944 e ao longo de toda a década de 1950, a questão do desenvolvimento não figurou como prioridade da atuação do Banco Internacional para Reconstrução e Desenvolvimento (BIRD) ${ }^{54}$. Por mais de uma década, o Banco se restringiu à provisão de empréstimos e garantias a projetos "produtivos", de forma a atrair investimento privado e não competir com bancos comerciais. $\mathrm{O}$ objetivo principal era a reconstrução dos países membros, e os clientes do Banco se restringiram sobretudo a países ricos ou de renda média. A maior parte do mundo (pós-)colonial, ou do então denominado "Terceiro Mundo", encontrava-se excluída da carteira de empréstimos da instituição, dada a priorização por clientes solventes e projetos que trouxessem lucro. Os empréstimos do banco eram "ligados" 55 , e não envolviam os mesmos montantes ou níveis de concessão oferecidos, por exemplo, no Plano Marshall. Assim, mesmo em relação à missão de reconstrução, o papel do Banco Mundial nos anos 1940 e 1950 foi relativamente pequeno diante das iniciativas de ajuda bilateral promovidas pelos EUA (KAPUR et al., 1997a; PEREIRA, 2014, pp. 534-37; TOUSSAINT, 2008, p.19).

É no fim da década de 1950, e principalmente nos anos 1960, que o desenvolvimento econômico em países pobres e/ou do então chamado "Terceiro Mundo" se torna o objetivo principal do Banco Mundial. Alguns fatores internacionais impulsionaram essa transformação,

\footnotetext{
${ }^{54}$ É a partir da década de 1950 que o termo "Banco Mundial" passa a ser mobilizado para designar a junção entre o BIRD e a Associação Internacional de Desenvolvimento (AID), criada sob o escopo do Banco no final da década (PEREIRA, 2014).

${ }^{55}$ Isto é, empréstimos condicionados a serem utilizados de maneira pré-determinada.
} 
que no ano de 1960 culminou na criação da Associação Internacional de Desenvolvimento (AID). Num contexto de consolidação da Guerra Fria, os processos de independência de excolônias na África e na Ásia colocavam o risco de revoluções socialistas, que se agravou em 1959 com a Revolução Cubana. O fortalecimento do movimento dos países não alinhados, no mesmo período, levava para o centro do debate internacional as questões de desenvolvimento econômico, e o Banco Mundial era progressivamente questionado em sua tarefa declarada de promover o desenvolvimento, na medida em que países de renda média exigiam condições concessionárias semelhantes àquelas oferecidas bilateralmente pelos EUA a seus parceiros estratégicos $^{56}$ (PEREIRA, 2014, p.538; TOUSSAINT, 2008, pp.26-28).

A criação da AID, proposta pelo Tesouro norte-americano em 1959, buscava responder a essas mudanças na conjuntura política e econômica internacional. Por meio dela, os EUA passaram a contar, sob sua estreita influência, com uma agência de auxílio externo aos países pobres. Ao mesmo tempo, o fato de a nova Associação fazer parte do Banco Mundial - uma organização multilateral - blindava o governo norte-americano de eventuais acusações contra o viés político da ajuda despendida pela AID (PEREIRA, 2014). Os Estados Unidos consolidavam, assim, a promoção do desenvolvimento no “Terceiro Mundo" como necessidade estratégica de primeira grandeza - e, com isso, solidificaram o Banco Mundial como ator crucial para levar adiante essa tarefa (TOUSSAINT, 2008).

As primeiras duas décadas do Banco Mundial garantiram à instituição a construção e a consolidação do que Pereira (2014, p.527) denomina uma "fachada técnica", advinda de sua priorização inicial de projetos lucrativos, sua proximidade com o mercado financeiro dos EUA e a ausência, até 1962, de qualquer empréstimo do BIRD para a área "social" (projetos voltados à saúde ou educação, por exemplo). Além disso, como afirmado, ao longo dos anos 1940 e 1950 os EUA priorizavam a ajuda bilateral como instrumento para conduzir operações mais explicitamente políticas, o que preservava o papel "técnico" do Banco. Essa missão alegadamente técnica, contudo, ocultou a utilização - já nos primeiros anos da instituição - de critérios eminentemente políticos para a aceitação de Estados clientes e determinação de condições de empréstimo. Por exemplo, o primeiro empréstimo do Banco, feito em 1947 à França, esteve condicionado à demissão prévia dos membros do governo associados ao Partido

\footnotetext{
56 A criação da AID esteve relacionada, ainda, com a criação do Fundo Especial das Nações Unidas para o Desenvolvimento Econômico (Sunfed) no final da década de 1950. O Sunfed visava financiar, em termos concessionários, os países em desenvolvimento. Seu surgimento representou, assim, uma pressão adicional para que o BIRD emprestasse a estes países em termos semelhantes (PEREIRA, 2014, p.538).
} 
Comunista, que então era parte da coalizão governante. Horas após a condição ter sido atendida, o empréstimo de US\$ 250 milhões foi concretizado em benefício do governo francês (TOUSSAINT, 2008, p.46). Desde muito cedo, portanto, o Banco atuou como agente político, embora sua força política internacional ainda fosse marcadamente limitada.

É ao longo dos anos 1960, assim, que o Banco Mundial se consolida como promotor do desenvolvimento em países do Sul Global - muitos dos quais ex-colônias, recentemente independentes. O Banco se expande significativamente no período, tanto em termos geográficos - iniciou operações em mais de 50 países ao longo da década - quanto em volume de empréstimos concedidos. Seus critérios para aprovação de crédito se tornaram menos rígidos, deixando de centrar na solvência e desviando o foco para os potenciais de crescimento e os tipos de política econômica adotada pelos governos dos Estados clientes. Ademais, a instituição passou a englobar, entre as iniciativas financiadas, projetos voltados para a área social marcadamente saúde e educação -, aprofundando também sua atuação como promotor de desenvolvimento agrícola, com base no crédito a projetos de alta tecnologia (PEREIRA, 2014, p. 537-40). Foram ampliados também, de maneira significativa, os montantes destinados à cooperação técnica, fortalecendo o Banco enquanto ator relevante na formulação de políticas e dinâmicas institucionais internas aos Estados de quem era credor. Como será visto adiante, nas décadas seguintes a instituição se tornaria (ao lado do FMI) um ator cada vez mais influente na prescrição, perante seus clientes, de estruturas institucionais e políticas socioeconômicas específicas - embora frequentemente apresentadas como técnicas e, portanto, desprovidas de carga política (PAYER, 1982; TOUSSAINT, 2008).

Pereira (2014, p. 540) argumenta que, apesar das transformações descritas acima, a concepção do Banco Mundial sobre desenvolvimento permaneceu relativamente perene ao longo de suas primeiras décadas. Em sintonia com grande parte da academia norte-americana do período e com os interesses do governo dos EUA, o Banco defendia uma noção de desenvolvimento sobretudo como aumento de capacidades produtivas, estas tidas "como função direta do investimento físico" (PEREIRA, 2014, p. 540). A forte ênfase no crescimento econômico implicou em uma secundarização do tema da desigualdade socioeconômica e mesmo da pobreza, tanto nos projetos quanto nos discursos do Banco na década de 1960. Teoricamente, tal posição se justificava pela afirmação da existência de trade-offs entre crescimento econômico e redução da desigualdade. Em outros termos, políticas que visavam a segunda não poderiam ser economicamente eficientes. Aliada a esta premissa, outra teoria que embasava a visão do Banco sobre desenvolvimento afirmava que o crescimento econômico era 
responsável, num primeiro momento, pela intensificação das desigualdades. Num segundo estágio, contudo, após um período de crescimento econômico sustentado, a renda se derramaria pela estrutura social, num processo geral de redução das desigualdades (PEREIRA, 2014, p. 541; TOUSSAINT, 2008, p.103). Em outros termos, o crescimento garantiria, no longo prazo, a melhoria nas condições de vida para toda a população, tanto os mais ricos quanto os mais pobres - ideia resumida na frase "uma maré que sobe eleva todos os barcos" (KAPUR et al, 1997a, p.54).

A concepção e atuação do Banco Mundial sobre desenvolvimento, no entanto, não permaneceram intocadas nas décadas que se seguiram, mas sofreram ajustes progressivos como consequência de mudanças no cenário da economia política internacional e na gestão interna da instituição. Sem deixar de afirmar a centralidade do crescimento econômico como objetivo do desenvolvimento, o Banco do fim dos anos 1960 e da década de 1970 - sob a presidência de Robert McNamara (1968-1981) - passou a aceitar que somente crescimento econômico não levaria à redução da pobreza ou desigualdade. O combate à pobreza, em particular, foi alçado à meta central da instituição, que em pouco tempo se tornou referência mundial na produção de conhecimento sobre o tema (KAPUR et al, 1997a, p. 51-55). Associado a esta mudança de ênfase estava um outro deslocamento na compreensão de desenvolvimento publicizada pelo Banco, aproximando-o da busca por segurança e estabilidade no mundo bipolar. Mobilizando uma doutrina já existente (PEREIRA, 2014, p. 543), a gestão McNamara afirmou a conexão entre más condições econômicas e a proliferação de radicalismos político-ideológicos, enfatizando o combate à pobreza e o desenvolvimento econômico dos países pobres como fundamentais à manutenção da segurança e da estabilidade política deles e, evidentemente, dos EUA. A luta contra a pobreza, em suma, consolidava-se como uma das frentes de combate a instabilidades locais e, por tabela, ao comunismo (PAYER, 1982; PEREIRA, 2014; TOUSSAINT, 2008).

O deslocamento para o combate à pobreza exigia ajustes às posições teóricas da instituição. A crença no "efeito derrame", por exemplo, foi progressivamente questionada, na medida em que crescimento econômico não se traduziu em redução das desigualdades, em boa parte do mundo. Igualmente, a noção de trade-offs entre crescimento e redução da pobreza precisou ser revista. $\mathrm{O}$ foco no combate à pobreza não podia significar um abandono de projetos considerados economicamente eficientes, de forma que a gestão McNamara passou a negar que os dois objetivos fossem mutuamente excludentes (KAPUR et al, 1997a, p. 215-17). Ambas as premissas, contudo, não desapareceriam completamente do repertório do Banco, e voltariam a 
ser ativadas nas décadas seguintes, em maior ou menor grau, como forma de sustentar teoricamente práticas implementadas pela instituição.

É importante ressaltar como, a partir dos anos 1970, as atividades do Banco Mundial voltadas à pesquisa econômica ampliaram-se significativamente. Até então, a instituição não era a referência mundial que viria a se tornar, em termos de pesquisa e produção de conhecimento sobre desenvolvimento econômico. As graduais transformações que vinham ocorrendo nas concepções e projetos do Banco Mundial, citadas acima, não estiveram fortemente sustentadas do ponto de vista teórico até o início da década de 1970. A ênfase no combate à pobreza, por exemplo, iniciou-se na instituição sem grande pesquisa ou elaboração prévia no tema: será nos anos 1970 que importantes conceitos operacionais serão estabelecidos, como as noções de "pobreza absoluta" e "desenvolvimento rural integrado" (PEREIRA, 2014, pp. 545-47). Com ênfase no desenvolvimento agrícola, o Banco Mundial foi se consolidando, assim, como referência também acadêmica sobre pobreza e desenvolvimento econômico. A publicação do livro "Redistribuição com crescimento", em 1979, representou essa consolidação, sendo seguido por diversas outras publicações do Banco nos anos seguintes. Dessa forma, nos anos 1990, quando passou a atuar intensamente nos territórios palestinos, o Banco Mundial já havia se estabelecido internacionalmente como importante fonte de pesquisas, uma autoridade em termos de desenvolvimento que influenciava as concepções e práticas da comunidade internacional sobre o tema. Como será visto adiante, o papel do Banco Mundial como produtor de conhecimento, seus enquadramentos teóricos predominantes, serão elementos importantes para as transformações aqui analisadas na Palestina ocupada.

A presidência de Robert McNamara foi também importante na consolidação de certos aspectos da cultura organizacional do Banco Mundial. Ao estipular metas de empréstimos aos Estados clientes, e ao associar a performance de funcionários aos montantes mobilizados nos programas e projetos de ajuda, a gestão do Banco fez emergir na instituição um "imperativo" de sempre buscar aumentar os volumes emprestados (HARRISON, 2004, p. 11; PEREIRA, 2014, p. 543). O oferecimento de empréstimos, assim, deixou de ser movido unicamente por considerações técnicas sobre, por exemplo, as condições socioeconômicas dos países clientes: a própria dinâmica institucional do Banco se tornou um fator a guiar os novos empréstimos, apontando sempre para a ampliação dos montantes envolvidos.

\subsubsection{Do ajuste estrutural ao projeto da governança}

A década de 1970 foi marcada por profundas transformações no sistema econômico internacional. A primeira crise do petróleo, em 1973, levou os EUA a uma situação de inflação 
constantemente alta, e em perigo de crescimento, aliada a baixas taxas de crescimento. Ademais, o valor do dólar encontrava-se em tendência de queda, o que preocupava o governo e o setor privado. Em 1979, com a segunda crise do petróleo, as pressões sobre a economia norte-americana aumentaram ainda mais, o que levou o Tesouro, sob a presidência de Paul Volcker, a promover um acentuado aumento em suas taxas de juros (EPSTEIN, 1985, p. 63133; KAPUR et al, 1997a, p. 21). Ao longo do ano seguinte, a drástica mudança desencadeou crises de endividamento nos países com empréstimos dos EUA. Grande parte dos empréstimos havia sido concedida sob taxas de juros flutuantes, de forma que o choque imposto por Volcker afetou diretamente os serviços das dívidas contraídas. Outros fatores agravaram a condição econômica dos países devedores, marcadamente a queda nos preços de produtos não relacionados ao petróleo, base das exportações de várias economias nacionais (KAPUR et al, 1997a, p. 503; TOUSSAINT, 2008, p. 127-130).

Em sintonia com as transformações no cenário econômico internacional, o Banco Mundial promoveu um deslocamento significativo em suas políticas de empréstimo, estabelecendo como nova modalidade o "ajuste estrutural". Tratava-se de uma linha de empréstimos voltados não para projetos de desenvolvimento - seja este concebido enquanto crescimento ou combate à pobreza -, mas para políticas específicas a serem implementadas domesticamente pelos governos dos países clientes (BABB, 2012, p. 275). As diretrizes de ajuste prescritas pelo Banco, a partir de 1979, enfatizavam sobretudo as reformas nas políticas macroeconômicas e fiscais dos Estados em desenvolvimento. Do lado fiscal, exigiam-se amplos cortes na máquina administrativa estatal, nos gastos com pessoal, nos subsídios ao consumo e em qualquer outro programa público de cunho social (TOUSSAINT; MILLET, 2010, pp. 1067). A redução de gastos públicos implicava, centralmente, a privatização de serviços públicos e empresas estatais. Para além da contração fiscal, prescrevia-se aos governos clientes a abertura de suas economias ao comércio internacional, através da redução de quotas e tarifas comerciais e da desvalorização cambial, que permitiria uma reorientação das economias nacionais rumo a uma expansão da produção para exportação (HARRISON, 2004, p.18; TOUSSAINT, 2008, pp.101-102). No âmbito das finanças, enfatizava-se igualmente a importância da liberalização dos fluxos de capitais, bem como da flexibilização nas regulamentações dos serviços financeiros. O objetivo geral era criar um ambiente propício à atração do investimento externo privado, concebido como o motor que poderia recolocar as economias endividadas no rumo do crescimento e da estabilização macroeconômica. Temas a priori importantes aos programas de ajuste, como a proteção a grupos sociais mais vulneráveis 
ou a possibilidade de perdão (parcial ou total) das dívidas, foram marcadamente excluídos dos debates internos do Banco Mundial e dos termos presentes nos empréstimos por ele concedidos sob a alcunha do ajuste estrutural (PEREIRA, 2014, p. 550-51).

Dessa forma, ao longo dos anos 1980 o Banco Mundial consolidou, como parte central de suas funções, a tarefa de monitoramento da performance de Estados clientes em matéria de política doméstica - macroeconômica e fiscal ${ }^{57}$. A liberalização econômica radical, aos poucos, se firmava como novo paradigma internacional, impulsionado por governos como os de Ronald Reagan, Margareth Thatcher e Helmut Kohl (HARVEY, 2008, pp. 49-69; KAPUR et al, 1997, p. 504). Em sintonia, as atividades de pesquisa do Banco deixaram de lado, ainda que por pouco tempo, a pobreza como alvo prioritário, passando a enfatizar as limitações do Estado em promover o desenvolvimento - e a eficiência das forças de mercado em fazê-lo (PEREIRA, 2014, pp. 551-53).

O ano de 1989 marca, de certa maneira, a consolidação e a formalização do novo paradigma político-econômico internacional, no que ficou conhecido como o Consenso de Washington $(\mathrm{CW})$. Fruto de uma reunião entre atores como o Tesouro norte-americano, o FMI, o Banco Mundial e a USAID, o Consenso de Washington ficou conhecido como um conjunto de dez políticas de reforma econômica que, juntas, compunham as diretrizes dessas instituições no período em questão (WILLIAMSON, 1990, p. 1). Mais do que isso, o consenso representava a consolidação de uma doutrina de política econômica e social, sustentada teoricamente por economistas de grandes think-tanks norte-americanos e aplicada por instituições como o Banco (BABB, 2012, p. 270). O estabelecimento do CW representou, assim, um momento de maturidade e consolidação das concepções e práticas lapidadas por esse conjunto de atores desde meados dos anos 1970 (PEREIRA, 2014, pp. 551-53).

Com o fim da Guerra Fria, a agenda neoliberal de ajuste estrutural encampada pelo Consenso de Washington teve, diante de si, novos territórios liberados para poder avançar. $\mathrm{O}$ Banco Mundial, mais uma vez, foi ator central na implementação dessa agenda em países do Leste Europeu, garantindo que a transição para o capitalismo se desse nos moldes estabelecidos pela nova doutrina político-econômica dominante (TOUSSAINT, 2008, p.72). De fato, o Banco

\footnotetext{
57 Os empréstimos do Banco Mundial voltados para o ajustamento estrutural se mantiveram relativamente pequenos no início da década de 1980. É sobretudo a partir do segundo mandato de Ronald Reagan, com a indicação de James Baker à secretaria do Tesouro, que o Banco Mundial passaria a adotar uma postura mais pragmática, centrada no ajuste como estratégia para o desenvolvimento e combate à dívida dos países clientes (BABB, 2012, p.276). Observa-se assim, ao longo da década de 1980, uma progressiva consolidação do ajuste como principal diretriz dos empréstimos realizados pelo Banco.
} 
entrou nos anos 1990 bastante fortalecido, após mais de uma década de aprimoramento das políticas de ajuste. É nesse contexto de virada da década que se consolidaram na instituição o que Pereira (2014, pp.553-56) considera "quatro coordenadas estratégicas", que se tornaram definidoras das práticas do Banco Mundial nos anos que se seguiram e, assim, são particularmente importantes para um estudo de sua atuação nos anos 1990.

A primeira coordenada foi o retorno da pobreza como tema fundamental, desde a segunda metade da década de 1980. Os efeitos sociais advindos das políticas de ajuste estrutural não podiam mais ser ignorados, e a crise econômica vivida por diferentes regiões do mundo colocava o tema da pobreza novamente no centro das discussões sobre desenvolvimento (BABB, 2013, pp.164-67). O combate à pobreza, contudo, passou a ser visto pelo Banco Mundial como compatível com a agenda de ajustes macroeconômicos, numa operação teórica de separação estrita entre o que seriam políticas sociais e políticas econômicas. A pobreza, segundo o Banco dos anos 1990, deveria ser combatida com uma combinação entre as duas, sendo a "política econômica" não mais que a aplicação dos programas de ajustamento, enquanto as "políticas sociais" seriam uma tentativa focalizada de conter os efeitos colaterais deste ajustamento. Em outras palavras, desde 1986 o Banco havia passado a lançar, juntamente com seus programas de ajuste, projetos paralelos paliativos e de proteção aos setores mais vulneráveis das sociedades (PEREIRA, 2014, pp.552-553). Como será visto adiante, sobretudo no caso da Zona Industrial de Gaza, essa combinação entre diretrizes econômicas neoliberais e programas voltados ao alívio das condições de vida dos setores mais vulneráveis foi uma característica presente na atuação do Banco Mundial nos territórios palestinos ocupados, a partir de 1993.

Uma segunda coordenada estratégica do Banco Mundial, estabelecida no período, foi a busca por englobar o tema da preservação ambiental na concepção de desenvolvimento difundida. Como na questão da luta contra a pobreza, o Banco articulou uma posição que apresenta o objetivo do crescimento econômico e as políticas de ajuste estrutural como não somente compatíveis, mas necessários à preservação do meio ambiente. Emerge assim, como uma das metas centrais da instituição, a noção de desenvolvimento sustentável, resultado de um mundo liberalizado onde o crescimento econômico e a inovação tecnológica diminuem a pressão sobre o meio ambiente, e permitem arcar com os custos de sua preservação (PEREIRA, 2014, pp. 554-555). As duas outras coordenadas estratégicas do Banco Mundial, no período, são particularmente importantes para a análise aqui realizada. Trata-se, de um lado, de uma revisão geral das funções atribuídas ao Estado no processo de desenvolvimento. De outro, e em 
estreita relação com essa revisão, tratou-se de elaborar um novo conceito, que se tornaria um dos principais organizadores da agenda do Banco na década de 1990: a noção de "governança".

No que tange ao papel do Estado, a posição do Banco Mundial - assim como dos principais atores associados ao Consenso de Washington - sofreu um deslocamento importante a partir dos anos 1990. Afastando-se das posturas "hipermercadistas" (PEREIRA, 2014, p. 554) que marcaram a década anterior, a concepção que passou a vigorar entende o Estado não mais como um entrave às forças de mercado, mas como um elemento necessário ao bom funcionamento delas (HARRISON, 2004, pp. 18-21). Ao invés de negar de todo o papel do Estado na vida econômica, tratou-se de delimitar as esferas legítimas de atuação do aparelho estatal, cujo objetivo seria o de maximizar os benefícios trazidos pela economia de mercado, difundindo a concorrência como princípio regulador de diferentes esferas da vida social, conforme discutido na introdução (DARDOT, LAVAL, 2016, pp. 164-82). O Estado surge, assim, mais como um complemento que como um contraponto ao mercado, sendo responsável por garantir o melhor ambiente possível ao capital privado. Dentre as funções do Estado estariam a garantia da ordem pública, dos direitos de propriedade e do cumprimento dos contratos, a manutenção da estabilidade macroeconômica (incluída, aqui, a liberdade dos fluxos financeiros), o fornecimento de infraestruturas e o investimento em "capital humano" básico. Em suma, cabe a esse Estado "repensado" garantir e proteger os entes privados da economia, assegurando entre eles a livre concorrência que, segundo a doutrina consolidada nos anos 1980, permitiria o máximo de eficiência econômica - e, portanto, de desenvolvimento (PEREIRA, 2014, p. 554).

A ascensão da ideia de governança ao centro dos discursos e práticas do Banco Mundial está estreitamente conectada com essa reformulação operada nas funções do Estado (HARRISON, 2004, p.18). O termo governança, mobilizado pela primeira vez pelo Banco em 1989, recebeu uma definição clara em 1992, na primeira publicação específica da instituição sobre o tema. Segundo o Banco Mundial, "governança" se refere à "maneira pela qual o poder é exercido na gestão de recursos sociais e econômicos de um país para o desenvolvimento" (BANCO MUNDIAL, 1992, p.1). O sucesso ou fracasso dos processos nacionais de desenvolvimento, assim, passou a ser concebido como resultado não de fatores externos ou do tamanho do Estado, e nem somente das políticas econômicas adequadas (embora estas ainda fossem tidas como fundamentais), mas sim da qualidade da gestão pública e da ação governamental em si - qualidade esta mensurada, evidentemente, segundo os critérios estabelecidos por instituições como o Banco ou o FMI. 
A emergência da noção de governança expressa, portanto, um momento de ênfase menor no tamanho do Estado, e maior na natureza de suas ações. Vão para o centro do debate sobre desenvolvimento, nesse contexto, questões como a construção de capacidade institucional nos Estados clientes, reformas nos incentivos que estruturam o serviço público, criação de expertise local em gestão financeira e de recursos humanos, novos padrões de transparência em processos de formulação e implementação de políticas públicas, foco na participação de setores sociais (notadamente organizações da sociedade civil) em tais processos, ênfase no uso de novas tecnologias como solução de gargalos econômicos e institucionais, entre outras diretrizes sobre como melhor conduzir a gestão pública. As mudanças na compreensão do Banco sobre como atingir melhores resultados em termos de desenvolvimento, assim, revelam um deslocamento em relação a preocupações anteriores: não se trata de determinar apenas o conteúdo da política mais adequada, mas também e centralmente os processos institucionais por meio dos quais se dará sua implementação (HARRISON, 2004, pp. 18-19).

Sob a alcunha da governança, questões como corrupção, burocratização, transparência e accountability passaram a ser consideradas elementos fundamentais para que os programas do Banco - dentre os quais os de ajuste - pudessem ter êxito. Num momento de interesse renovado no papel do Estado, portanto, o conceito de governança passou a embasar e orientar a ação de instituições como o Banco Mundial, numa busca por "reformar" as estruturas institucionais e práticas governamentais dos Estados sob sua influência. Este momento de ênfase na governança recebeu diferentes nomes, como Consenso Pós-Washington ou Segunda Geração de Reformas (HARRISON, 2004, pp.18-20). Embora este novo paradigma seja comumente visto como um conjunto de diretrizes fundamentalmente distinto daquele típico dos anos 1980, devido a sua renovada valorização do Estado, Harrison (2004, pp.19-20) aponta para a relação de continuidade, e mesmo de intensificação entre os dois "consensos". Ainda que volte a legitimar a atuação estatal, é importante notar que a Segunda Geração, assim como a primeira, tem como objetivo final aprofundar e consolidar as forças globalizadas de livremercado, tomadas como principal pilar da vida social e como único motor possível para o desenvolvimento econômico sustentado. Em realidade, o conjunto de posições e políticas defendidas nos anos 1990, geralmente em nome da boa governança, pressupõe o sucesso das premissas que embasaram o Consenso de Washington e as diretrizes do ajuste estrutural dos anos 1980. Trata-se, antes, de uma ortodoxia em processo de consolidação do que de uma verdadeira transformação na doutrina político-econômica dominante (HARRISON, 2004, p.20). 
Com a noção de governança, a lógica de ajuste estrutural pode ser tornada permanente. Enquanto o ajuste era concebido como uma política a ser implementada num período específico de tempo, a diretriz da governança permite enraizar permanentemente, nas estruturas e dinâmicas institucionais dos Estados, certos comportamentos considerados indispensáveis para a promoção do desenvolvimento econômico. Assim, a agenda da governança permite, a instituições como o Banco Mundial, difundir as "melhores práticas" e "padrões internacionais" de gestão pública aos governos para quem empresta. Como resultado, transformou-se o ajuste estrutural - originalmente concebido como uma prescrição para a gestão de crises - numa conduta internalizada dos Estados, e, portanto, constantemente prevista (DARDOT; LAVAL, 2016, pp.311-314; HARRISON, 2004, p. 20).

A difusão da categoria política da governança, por atores como o Banco Mundial, foi parte central da transformação, brevemente discutida na introdução, operada pela governamentalidade neoliberal nas dimensões políticas da vida social. Aliada a noções como "melhores práticas" e "benchmarking", a governança remodela a esfera política e as práticas nela inseridas, concebendo-as em termos de administração técnica. A deliberação coletiva sobre condições presentes e futuros políticos alternativos; expressões substantivas de posições políticas opostas; ou a própria ideia de mandato político: sob a alcunha da governança, elementos típicos do regime político democrático dão lugar à solução de problemas técnicos. Termos como descentralização e participação, também bastante presentes nas prescrições feitas em nome da boa governança, são em geral mobilizados como parte de um modelo de gestão pública concebido em termos de "stakeholders", engajados na formulação de políticas públicas específicas (isto é, temáticas) por meio de atividades como "advocacy" e "lobby" (BROWN, 2015, pp.122-127; DARDOT; LAVAL, 2016, p.312). Realiza-se assim, como fruto de um “enorme trabalho de redução do sentido da ação pública" (DARDOT; LAVAL, 2016, p.312), uma gradual transformação na forma de conceber o âmbito político, retirando da ação pública justamente suas características mais inerentemente políticas. A noção de governança, ainda, permite a instituições como o Banco Mundial a preservação de "fachadas técnicas", isto é, a apresentação de suas prescrições como supostamente desprovidas de carga política (PEREIRA, 2014, p.527). Como será visto, tal operação está presente nos estudos feitos pelo Banco no início de 1993, nos TPO.

Portanto, é em seu momento de "entronização da ideia de governança" (PEREIRA, 2014, p.555) que o Banco Mundial chega aos territórios palestinos ocupados, no início dos anos 1990. O restante deste capítulo buscará analisar como esse conjunto de concepções e práticas 
do Banco - não apenas de governança, mas de reforma estrutural, desenvolvimento socioeconômico e institucional, entre outras - foram mobilizadas pela instituição no contexto dos TPO, a partir do início dos "processos de paz".

\subsubsection{Um vetor do capitalismo neoliberal e colonial}

De forma ampla, duas perspectivas analíticas tendem a predominar em estudos sobre o Banco Mundial. Uma primeira enfatiza as características institucionais do Banco, dando maior peso à evolução de suas agendas, gestões e dinâmicas organizacionais internas como principal fator a explicar a atuação da instituição ao longo das décadas. O Banco Mundial, nessa perspectiva, aparece antes de mais nada como uma burocracia complexa ou tecnocracia, cujas práticas são explicadas a partir de aspectos institucionais - evidentemente, em relação com processos e contextos externos (KAPUR et al., 1997a; 1997b; MILLER-ADAMS, 1999). De outro lado, autores como Payer (1982), Harrison (2004) e Toussaint (2008) compreendem o Banco sobretudo como um agente posicionado em uma certa economia política internacional. A natureza das ações da instituição seria, primordialmente, resultante de uma estrutura internacional de poder historicamente específica, sendo o Banco um instrumento, ou um representante de diferentes momentos dessa estrutura (HARRISON, 2004). É em relação a essas dinâmicas estruturais e históricas, assim, que as atividades da instituição ganham sentido. Essa dissertação compartilha da segunda perspectiva para afirmar uma compreensão do Banco e, com isso, analisar sua atuação nos territórios palestinos ocupados.

Segundo a perspectiva adotada, a agência do Banco Mundial não pode ser compreendida sem que se faça referência às estruturas mais amplas da economia política internacional das quais ele é parte integrante. É nesse sentido que, como busca essa pesquisa, um estudo sobre a atuação do Banco nos anos 1990 e 2000 deve se sustentar em uma análise dos processos globais de avanço do neoliberalismo - paradigma dominante no período -, enfatizando a inserção da instituição nesses processos. Assim, esta dissertação segue Harrison (2004, p.8) na definição do Banco enquanto "um 'momento' político-institucional numa economia política internacional mais ampla": fundado para ser um banco de desenvolvimento a nível global, o Banco Mundial atuou sempre como um vetor da atividade econômica capitalista. Como desenvolvido acima, esta atuação básica envolveu desvios e mudanças de ênfase, em grande medida devido a transformações na conjuntura política e econômica internacional. Pode-se dizer, então, que o Banco representou diferentes momentos e paradigmas do avanço capitalista na segunda metade do século XX, sem nunca fugir de alguns objetivos e características basilares. 
$\mathrm{Na}$ medida em que o capitalismo esteve intimamente ligado ao liberalismo, ao menos no século XX, o Banco Mundial funcionou também como vetor internacional de um projeto especificamente liberal de transformação das economias nacionais (WILLIAMS, 2008). Isso não significou, contudo, apoio à dimensão política do liberalismo. Ao contrário, desde sua criação o Banco Mundial nunca deixou de emprestar a governos não democráticos, como nos casos de Pinochet, no Chile, e de Ferdinand Marcos, nas Filipinas, demonstrando a disposição da instituição em relevar aspectos autoritários dos governos clientes, desde que esses não se desviassem do curso do desenvolvimento capitalista. Enquanto vetor do capitalismo internacional, ainda, o Banco tampouco se ausentou da colaboração com poderes coloniais. $\mathrm{Na}$ medida em que o sistema capitalista do século XX se desenvolveu de forma estreitamente associada ao colonialismo, pode-se dizer que o Banco foi antes um dos vetores de tal associação que um opositor a ela. Em termos concretos, a instituição financiou projetos de países como a França, a Bélgica e o Reino Unido, antes que suas colônias obtivessem independência. Mais do que isso, o Banco não perdoou dívidas contraídas pelas forças coloniais, mas as transferiu para os governos recentemente independentes, que viram seus países iniciarem a vida soberana já sob o peso de dívidas - contraídas por seus antigos dominadores (TOUSSAINT, 2008, pp.2225).

Em suma, ao longo da segunda metade do século XX o Banco Mundial agiu de forma sinérgica às principais tendências do capitalismo internacional. Atuando como vetor de expansão da atividade capitalista a nível global, o Banco não se desviou de algumas das principais características do sistema capitalista no período, como o colonialismo e o liberalismo. Conforme o neoliberalismo emergiu como novo paradigma dominante, no fim do século, o Banco progressivamente adequou suas concepções e práticas e, na medida em que o capitalismo neoliberal continuou intrinsecamente associado ao colonialismo, a instituição se transformou num vetor global do neoliberalismo também em suas variantes coloniais.

Por fim, um tema importante no debate sobre a natureza das ações do Banco Mundial é o da influência dos Estados Unidos sobre a agenda e as práticas da instituição. Payer (1982, p. 42) e Toussaint (2008, pp.43-47) são exemplos de uma literatura que caracteriza a relação entre o governo norte-americano e o Banco como uma de controle direto. A atuação do Banco ao longo das décadas, de fato, foi fortemente determinada pelos objetivos políticos e econômicos estabelecidos pela Casa Branca ou pelo Tesouro dos EUA (PEREIRA, 2014). Da localização do Banco - a poucos quarteirões da Casa Branca - às composições de sua mesa diretora, passando pelo poder de veto que os EUA têm na instituição e pelo fato de que todos os seus 
presidentes, ao longo do século XX, foram norte-americanos indicados pelo governo: uma série de elementos, na história do Banco Mundial, atestam a profunda influência do governo dos EUA sobre as diretrizes perseguidas pela instituição (PAYER, 1982, p.42; TOUSSAINT, 2008, pp.43-47). Nessa dissertação, contudo, evita-se analisar as políticas do Banco como frutos diretos da influência norte-americana - sem negar a absoluta importância de tal influência. Antes, como discutido nesta seção, localiza-se a atuação da instituição como produto (nem sempre coerente) de um sistema político-econômico global - o neoliberalismo. Evidentemente, os Estados Unidos ocupam o centro desse sistema e, nesse sentido, é natural que tenham grande importância para seu funcionamento - e para o funcionamento dos vetores de tal sistema, como o Banco. Contudo, o neoliberalismo colonial global, enquanto fenômeno, é mais amplo que a política norte-americana: embora o objetivo estratégico possa ser semelhante - aprofundar a dominação capitalista por meio, entre outros fatores, da dominação colonial -, os vetores concretos do neoliberalismo mobilizam dispositivos diversos, e através deles geram efeitos locais específicos. Assim, interessa aqui produzir uma análise dos dispositivos difundidos pelo Banco Mundial nos TPO - por meio da assistência financeira -, sem que isso signifique considerar a produção de tais dispositivos como causa direta da política norte-americana para a Palestina ocupada.

Portanto, partindo de uma compreensão do Banco não apenas como ator político, mas como agente de uma certa estrutura e de um certo paradigma político-econômico dominantes, trata-se de analisar o "projeto global de engenharia sócio-política" (HARRISON, 2004, p.3) posto em operação pela instituição nos territórios palestinos ocupados, cujos resultados incluíram a emergência de um ente quase-estatal específico e transformações importantes na economia e sociedade palestinas dos TPO. No restante deste capítulo, assim, busca-se analisar a concepção de desenvolvimento socioeconômico que o Banco Mundial passou a difundir nos TPO, a partir dos "processos de paz", destacando os dispositivos pelos quais tal difusão se deu e, sobretudo, enfatizando os efeitos desta concepção de desenvolvimento para a realidade política, econômica e social dos territórios ocupados.

\subsection{O Banco Mundial na Palestina ocupada (1993-1994)}

Atendendo ao pedido da comunidade internacional de doadores por auxílio técnico, para elaborar um enquadramento de análise e um plano de ação para os TPO, uma missão do Banco Mundial visitou os territórios ocupados entre 11 de outubro e 22 de novembro de 1993, em seguida indo à Tunísia para confirmar com a OLP os objetivos da missão. O grupo do Banco 
Mundial - acompanhado por representantes de uma série de governos, agências da ONU, instituições financeiras, organizações não governamentais locais, entre outros membros da comunidade doadora - viajou extensivamente pela Cisjordânia e pela Faixa de Gaza no período, recebendo "excelente cooperação das autoridades palestina e israelense" e "encontrando-se com um amplo espectro de palestinos preocupados com questões de transição e desenvolvimento socioeconômico" (BANCO MUNDIAL, 1994a, p. vii).

Como resultado dos trabalhos realizados por sua missão nos TPO, o Banco Mundial preparou um documento de dois volumes denominado "Assistência Emergencial aos Territórios Ocupados"58, que foi oficialmente publicado em março de 1994, após rascunhos dos estudos terem sido discutidos com as lideranças palestina e israelense. Com base nos achados e nas conclusões dos relatórios, o Banco concebeu em 1994 seu primeiro programa de assistência ao desenvolvimento dos TPO, denominado "Programa de Assistência Emergencial aos Territórios Ocupados"59. O objetivo do programa era delinear as prioridades em termos de investimento e de assistência técnica aos TPO para o período de 1994-1996, atendendo às necessidades palestinas imediatas e criando as condições para um desenvolvimento socioeconômico e institucional sustentável nos territórios ocupados (BANCO MUNDIAL, 1994a, p. 1).

Contudo, como afirmado anteriormente, essa não havia sido a primeira missão do Banco Mundial aos TPO, no contexto dos “processos de paz”, e tampouco o estudo sobre assistência emergencial lançado em 1994 havia sido o primeiro trabalho da instituição sobre os territórios. A partir de 1992, na esteira da Conferência de Madrid e do esforço norte-americano por impulsionar um processo de paz no Oriente Médio, o Banco Mundial passou a se implicar ativamente no suporte econômico e técnico sem o qual, acreditava-se, tal processo não poderia ser bem-sucedido. Solicitado pelo Grupo de Trabalho sobre Desenvolvimento Econômico - um dos GTs oriundos da etapa multilateral da Conferência de Madrid ${ }^{60}$ - uma primeira missão do Banco Mundial havia visitado os territórios ocupados entre janeiro e fevereiro de 1993 - isto é, antes mesmo do anúncio da existência de negociações secretas entre palestinos e israelenses, em Oslo (BANCO MUNDIAL, 1993a, p.vii). Como resultado, foi publicado um grande estudo sobre os TPO denominado “Desenvolvendo os Territórios Ocupados: um Investimento na Paz”,

\footnotetext{
${ }^{58}$ No original, "Emergency Assistance to the Occupied Territories" (BANCO MUNDIAL, 1994a).

${ }^{59}$ No original, "Emergency Assistance Program for the Occupied Territories" (BANCO MUNDIAL, 1994b, c).

${ }^{60}$ Com o fim da Conferência de Madrid, iniciou-se a "fase multilateral" do processo de paz. Grupos de trabalho foram criados para tratar de cinco temas: Desenvolvimento Econômico Regional, Segurança e Desarmamento, Recursos Hídricos, Refugiados e Meio Ambiente. Disponível em: 〈http://europa.eu/rapid/press-release_MEMO92-30_en.htm>. Acesso em: 04 mar. 2019.
} 
lançado em setembro de 1993, pouco antes da assinatura da Declaração de Princípios (BANCO MUNDIAL, 1994a, p. 5).

O estudo do Banco Mundial é composto por seis volumes. O primeiro se dedica a traçar um panorama geral da situação nos TPO, funcionando como um resumo das principais conclusões e recomendações às quais a missão do Banco Mundial chegou. Os cinco volumes subsequentes dedicam-se a temas específicos, nesta ordem: Macroeconomia; Desenvolvimento do Setor Privado; Agricultura; Infraestrutura; Recursos Humanos e Política Social. Totalizando mais de 500 páginas, os estudos publicados pelo Banco, logo antes dos acordos de Oslo serem anunciados, imediatamente se tornaram o material mais abrangente a analisar as condições socioeconômicas da Cisjordânia e da Faixa de Gaza. Cumpriram, dessa forma, o papel de orientar o início das movimentações de toda a comunidade doadora em 1993, funcionando também como o ponto de partida para a segunda missão do Banco nos TPO e para a elaboração do programa emergencial lançado pela instituição no ano seguinte (BANCO MUNDIAL, 1994c). Dada a relevância destes primeiros estudos em consolidar os termos e enquadramentos gerais a partir dos quais o desenvolvimento dos TPO seria tratado pela comunidade de doadores internacionais, o restante deste capítulo realiza uma análise focada nos estudos de 1993. Mais especificamente, são analisadas as posições apresentadas e as diretrizes prescritas pelo Banco Mundial no que tange a três transformações econômicas tradicionalmente observadas em processos de neoliberalização: a liberalização comercial, a financeirização (ou liberalização financeira) e a privatização. Nos próximos capítulos, realizam-se análises de projetos de desenvolvimentos concretos, nos quais a participação do Banco Mundial - e, em menor medida, da USAID - foi central, buscando assim enfatizar os efeitos da abordagem neoliberal difundida por esses atores para a economia e sociedade palestinas dos territórios.

\subsection{1. "Desenvolvendo os Territórios Ocupados: um investimento na paz"}

De acordo com Abdallah Bouhabib (1994, p.65), os estudos de 1993 foram realizados pelo Banco sem que se soubesse da iminência de um acordo bilateral entre Israel e a OLP. Como afirmado, a primeira missão do Banco aos TPO havia sido resultado dos processos regionais de paz, iniciados em Madrid em 1991. Contudo, o momento em que os relatórios foram publicados - poucas semanas antes do famoso aperto de mão entre Arafat e Rabin sugere que a instituição havia sido informada, ao longo de 1993, da existência de negociações bilaterais secretas entre palestinos e israelenses, paralelas aos processos iniciados em Madrid. De qualquer forma, quando a Declaração de Princípios foi assinada, um complexo enquadramento de análise já estava montado para dar início à assistência internacional aos TPO. 
Embora em sintonia com o andamento dos processos políticos, e buscando influenciá-los positivamente, a atuação do Banco Mundial no contexto aqui analisado não se desviou de sua tradicional fachada técnica, discutida anteriormente. Pelo contrário, o Banco buscou construir um enquadramento de análise que separasse a atuação da comunidade de assistência externa das dimensões mais propriamente políticas dos "processos de paz", apresentando assim a assistência internacional como um conjunto de operações relativamente descarregadas de conteúdo político. A próxima subseção enfoca esse aspecto do enquadramento produzido pelos relatórios de 1993.

\subsubsection{1. "Uma missão técnica"}

O estudo "Desenvolvendo os Territórios Ocupados: um investimento na paz" não nega que o futuro do desenvolvimento social, econômico e institucional dos TPO depende, em grande medida, do futuro das negociações políticas entre israelenses e palestinos. Contudo,

\footnotetext{
"[c]omo a missão do Banco para os $\mathrm{TO}^{61}$ é uma missão técnica, sem o mandato ou a expertise para lidar com aspectos políticos ou de segurança, este estudo não toma nenhuma posição em questões que estão na agenda para negociações bilaterais. $\mathrm{O}$ foco, ao invés disso, é em políticas públicas [policies], instituições e investimentos, onde escolhas ótimas são amplamente independentes dos eventuais arranjos políticos" (BANCO MUNDIAL, 1993a, p.1 - grifo no original).
}

Percebe-se explícita, no trecho, a compreensão de que instituições e políticas públicas (policies) podem ser objetivamente "ótimas"62, isto é, relativamente independentes do contexto político em que se inserem e frutos unicamente do conhecimento técnico. Mais, políticas e instituições são apresentadas no texto como equivalentes a investimentos, os quais o Banco assume ter "mandato" e "expertise" para gerir. Assim, não negando a natureza altamente politizada da situação em que se inseria, o Banco afirma que, apesar dessa natureza, existia um espaço para além da dimensão política, separado dela, onde a ação técnica dos doadores internacionais poderia trazer benefícios objetivos.

A referência ao caráter técnico da atuação do Banco Mundial não está presente apenas nos estudos de 1993, mas em vários documentos e manifestações de oficiais da instituição nos anos seguintes. Perguntado acerca de contribuições dos israelenses ao Programa de Assistência Emergencial, Bouhabib (1994, pp. 70-71) expressa a posição do Banco, que não diferia da postura mais geral adotada pela comunidade de assistência internacional, de apoio à cooperação

\footnotetext{
${ }^{61}$ Nos documentos do Banco Mundial, os territórios palestinos da Cisjordânia e Faixa de Gaza são, em geral, denominados apenas de "Territórios Ocupados" (TO).

${ }^{62}$ É visando destacar essa concepção técnica sobre as políticas públicas que, nessa dissertação, sempre se destacará o uso do termo "policy" nas traduções realizadas de trechos dos documentos analisados.
} 
entre os dois lados e compreensão de sua necessidade para obter a "paz”. Para tanto, reforça o posicionamento politicamente neutro da instituição:

Sim, eles [israelenses] tiveram algumas [contribuições]. Até segunda ordem, eles ainda são a autoridade soberana lá, e como uma organização internacional nãopolítica, nós precisamos levar isso em consideração [...]. Os palestinos aceitam o fato de que os israelenses precisam saber o que está acontecendo, e de que eles dão suas opiniões. Não tem havido nenhum problema maior nesse quesito. Claro, há problemas sobre as grandes questões políticas - Jerusalém, os refugiados, e assim por diante mas estas não são parte do nosso trabalho; nós apenas as colocamos de lado.

O Banco Mundial concebe suas atividades nos TPO como se suas prescrições para o desenvolvimento da Cisjordânia e da Faixa de Gaza não tivessem consequências políticas para uma população sob ocupação militar há mais de duas décadas. Tais prescrições se pretendem expressões de um conhecimento especializado aplicado, separável e separado do âmbito político e, assim, pouco influenciado por suas problemáticas. É partindo da premissa de que uma separação operacional entre dinâmicas políticas e econômicas é possível que o Banco Mundial se propõe a estudar o passado econômico dos territórios palestinos, propor enquadramentos, estabelecer diagnósticos e prescrever políticas. O alto nível técnico do Banco leva, por vezes, a complexos cenários e modelos econômicos, por meio dos quais projeções de custos, benefícios e riscos são avaliadas. Nas seções seguintes, buscaremos expor a compreensão geral do Banco presente no estudo publicado em 1993. Sem pretender uma análise exaustiva dos seis volumes, enfatizamos os três subprocessos mencionados acima, característicos da neoliberalização em sua dimensão mais eminentemente econômica: privatização, liberalização comercial e financeirização. Tampouco busca-se realizar uma análise dentro dos termos propostos pelo relatório, isto é, tomando como válidas as premissas sobre as quais o Banco constrói o estudo - como, por exemplo, a premissa citada acima da possibilidade de separação entre atuação política e econômica. Antes, compreendendo a centralidade do Banco como produtor de conhecimento sobre os TPO no momento analisado, busca-se sublinhar como o estudo aponta alguns horizontes estratégicos para o desenvolvimento socioeconômico da Cisjordânia e da Faixa de Gaza. Ao fazê-lo, evidentemente fecha outros horizontes, fortalecendo assim um enquadramento específico a partir do qual a questão deve ser pensada, uma referência teórica e prática - às mãos da comunidade internacional de doadores. É nesse sentido que, nessa dissertação, os diagnósticos, descrições e prescrições do Banco Mundial e da USAID para os TPO são compreendidos como dispositivos, como elementos que intervém nas correlações de forças locais de forma a impulsioná-las, mais ou menos coerentemente, em direção a certos objetivos estratégicos (geralmente não explicitados) (FOUCAULT, 2001). 


\subsubsection{2. "Um Breve Perfil"}

O primeiro volume dos estudos do Banco Mundial se inicia com um box de pouco menos de uma página chamado "Os Territórios Ocupados: Um Breve Perfil”, onde se apresenta uma descrição rápida e simplificada da história da questão palestina-israelense ao longo do século XX (BANCO MUNDIAL, 1993a, p.viii). Sem fazer referência a quais populações viviam na Palestina histórica no início do século, ou no final do século XIX, o relatório descreve rapidamente quais forças "dominaram" a região ao longo do tempo: até o fim da Primeira Guerra Mundial, o domínio do Império Otomano e, depois disso, a transformação da Palestina num Mandato Britânico. Sem mencionar mudanças sociais e demográficas concretizadas pelo projeto sionista no período - e apoiadas pelo Mandato Britânico (PAPPE, 2006a, pp.72-79) o relatório descreve os anos de 1947-1948 da seguinte forma:

\section{A escalada de conflitos e as tentativas britânicas malsucedidas de mediar entre os nacionalismos judeu e palestino levaram a Grã-Bretanha a retornar o mandato para a ONU em 1947. A ONU sugeriu independência palestina e judaica com base em uma partilha. Os palestinos e árabes rejeitaram a sugestão, e o Estado de Israel foi proclamado em 1948. Na sequência do conflito militar que seguiu, a Faixa de Gaza ficou sob controle egípcio e a Cisjordânia, sob controle jordaniano (BANCO MUNDIAL, 1993a, p.viii).}

Neste trecho, um conflito surgido como resultado de décadas de uma política colonial europeia sobre a Palestina histórica é reduzido a uma oposição entre nacionalismos, cuja violência eventualmente escalonou a níveis não mais suportáveis pela administração britânica. Não é abordado o apoio britânico às ondas de imigração judaica à Palestina, seu apoio militar às milícias sionistas ou sua forte repressão às revoltas palestinas, sobretudo no final da década de 1930 (PAPPE, 2006a). A respeito do fim do mandato britânico, o "Breve Perfil” não oferece as porcentagens de populações palestina e judaica no território no período, nem cita a desproporcional distribuição geográfica proposta pelo Plano de Partilha da ONU ${ }^{63}$. Tampouco se faz referência ao fato de que o Estado de Israel, que viria a ser proclamado em maio de 1948, desrespeitou as fronteiras estabelecidas pelo próprio Plano da ONU. Ao contrário, todo o processo é descrito como se a proposta de partilha fosse politicamente neutra: o lado judeu a aceitou, e obteve seu Estado; o lado palestino a recusou, e ficou sem o seu.

Para designar a limpeza étnica de centenas de vilas palestinas por milícias sionistas ao longo dos anos de 1947-1948 - a Nakba, ou Catástrofe Palestina - o relatório do Banco Mundial utiliza o termo "conflito militar", reduzindo este processo histórico à Guerra Árabe-Israelense

\footnotetext{
${ }^{63}$ A partilha proposta no Plano da ONU de 1947 destinava 55,5\% do território da Palestina histórica à população judaica, que à época representava pouco menos de um terço da população total e era proprietária de cerca de $7 \%$ das terras. Os palestinos, quase $70 \%$ da população, teriam $45,5 \%$ do território para estabelecer um Estado (KHALIDI, WALID, 1997, p.11).
} 
iniciada em maio de 1948, diante da Declaração de Independência de Israel. O ataque sionista às vilas palestinas, na verdade, começara meses antes, sendo que em 15 de maio de 1948 - dia da Independência - quase 250 mil palestinos já haviam sido expulsos de suas casas (PAPPE, 2006b, p.xv). As vilas palestinas há muito haviam sido desarmadas, e suas lideranças presas ou mortas pela repressão britânica, de forma que um conflito militar estava longe de descrever a realidade nos meses anteriores à Declaração de Independência de Israel. A declaração de guerra dos países árabes vizinhos, em maio, tampouco adicionou muito em termos de proteção às populações palestinas das vilas, que tiveram poucas alternativas que não fugir, diante da violência perpetradas pelas milícias sionistas - as quais, após maio, se tornaram os primeiros membros das Forças de Defesa Israelenses (FDI) (MASALHA, 2012; PAPPE, 2006a; 2006b).

Acerca das populações palestinas refugiadas, o "Breve Perfil” do Banco Mundial descreve a situação no início da década de 1990, bem como as perspectivas diante do início dos "processos de paz":

Estima-se que, atualmente, em torno de 3,5 milhões de palestinos vivem fora dos TO. Alguns mantiveram direitos de residência nos TO e estão, em princípio, livres para retornar, enquanto o retorno de outros será objeto de negociação entre Israel e os palestinos. Quantos palestinos deverão efetivamente retornar dependeria, também, das percepções sobre oportunidades econômicas futuras nos TO (BANCO MUNDIAL, 1993a, p.viii).

Alguns pontos podem ser destacados acerca deste trecho. Em primeiro lugar, o relatório equipara o setor da população refugiada palestina que, efetivamente, exerce seu direito de retorno, com o setor, incomparavelmente maior, de palestinos que nunca puderam retornar a sua terra natal. A leitura do texto não indica, em nenhum momento, a dimensão da violação de direitos internacionais em questão. Sugere, unicamente, que o destino dos “outros" palestinos - que em realidade representam a imensa maioria dos refugiados - dependerá de negociações futuras. Aqui há um segundo ponto a ser destacado: o relatório omite a recusa de Israel em abordar a questão do refúgio. A leitura não torna explícito o adiamento ativo, por pressão israelense, da questão do refúgio para negociações futuras. Como indica Said (2003), este era, desde muito cedo, um sinal evidente dos reais objetivos estratégicos de Oslo. Ainda neste ponto, o relatório tampouco indica o fato de que, mesmo que os refugiados de 1967 obtivessem exercício do direito de retorno, a solução de dois Estados incorporada por Oslo e aceita pela OLP significava o abandono do direito ao retorno dos refugiados palestinos de 1948.

Um terceiro ponto a ser destacado diz respeito às perspectivas que o relatório enfatiza para a realização futura do direito de retorno. Para além das "negociações” políticas, sobre as quais o box não tem muito a dizer, a ênfase recai no elemento econômico: as "percepções sobre oportunidades econômicas futuras nos TO” serão um motor crucial para o retorno dos 
refugiados palestinos. Novamente, há uma separação procedimental entre política e economia e uma minimização dos fatores políticos em prol de uma linguagem econômica. Parece efetivamente sumir de vista o fato de que as perspectivas econômicas para os TPO dependiam, inteiramente, do fim da ocupação israelense e da realização dos direitos palestinos - dentre os quais, o direito de retorno.

A ausência de referências mais diretas à ocupação israelense é frequentemente compensada, ao longo do estudo, pelo uso de linguagem e jargões econômicos. Refere-se, por exemplo, à condição "altamente vulnerável a desenvolvimentos externos" (BANCO MUNDIAL, 1993a, p.1) da economia dos TPO e aos "sérios desequilíbrios" (BANCO MUNDIAL, 1993a, p.4, grifado no original), ou "distorções" e "desequilíbrios estruturais" enfrentados por ela desde 1967. Embora o estudo reconheça, no "Breve Perfil" discutido acima, que "uma característica marcante da economia dos TO é sua pesada dependência na economia israelense" (BANCO MUNDIAL, 1993a, p.viii), poucas vezes essa dependência é atribuída à soberania israelense nos TPO (seu controle sobre fronteiras, recursos naturais, arrecadação de impostos, controle sobre legislações e assim por diante, cujos efeitos foram discutidos na introdução). De forma semelhante, embora no "Breve Perfill” seja mencionado que, até o recente fechamento das fronteiras “com” (e não “por”) Israel (decorrente da primeira Intifada), um terço da força de trabalho palestina trabalhava em Israel, e mais de $90 \%$ do comércio dos territórios era com o país (BANCO MUNDIAL, 1993a, p. viii), ao longo do relatório a situação do mercado de trabalho nos TPO passa a ser descrita apenas como uma de "dependência de fontes externas de emprego" (BANCO MUNDIAL, 1993a, p.5).

A separação entre economia e política faz com que o relatório do Banco Mundial descreva a realidade econômica dos territórios ocupados - ela mesma uma consequência da ocupação israelense - sem que a responsabilidade de Israel surja como causa evidente destas condições e distorções econômicas. As origens políticas do sofrimento econômico das populações palestinas dos TPO, assim, são reduzidas a "desequilíbrios estruturais" (como o predomínio do setor de serviços em detrimento dos setores industriais e agrícolas), sem que estes apareçam como resultados de 25 anos de ocupação militar e expansão colonial israelense. Não se torna conclusão evidente, portanto, que enquanto a soberania israelense não fosse efetivamente retirada, tais desequilíbrios econômicos não poderiam ser definitivamente resolvidos. Os efeitos de tal visão ficarão evidentes no próximo capítulo, ao se analisar a iniciativa da Zona Industrial de Gaza. 


\subsubsection{Uma economia aberta e voltada à exportação}

Embora considere o bom andamento das negociações políticas uma condição necessária ao desenvolvimento econômico dos TPO, o Banco Mundial ressalta que a resolução dos impasses políticos não é suficiente para garantir desenvolvimento econômico nos territórios. "Muito dependerá da qualidade da gestão econômica no período pós-paz e das escolhas estratégicas feitas" (BANCO MUNDIAL, 1993a, p.13 - grifo no original) a respeito dessa gestão. O estudo aponta dois conjuntos de escolhas que, na concepção apresentada, são "particularmente críticas" para a futura trajetória de desenvolvimento dos territórios: (i) "o equilíbrio entre os papéis dos setores público e privado nos OT" e (ii) "a natureza das relações econômicas dos OT com o resto do mundo, particularmente países vizinhos" (BANCO MUNDIAL, 1993a, p.13 - grifo no original). Nessa subseção e na próxima, enfatiza-se o segundo conjunto de escolhas estratégicas apontadas pelo Banco: a questão da liberalização comercial e financeira dos territórios. Após essa discussão, as subseções seguintes analisam a outra escolha estratégica que seria enfrentada pela nova autoridade: qual deveria ser a função, o tamanho relativo e os limites de atuação da entidade autônoma palestina, a ser criada nos anos seguintes, e que tipo de relação ela deveria ter com o setor privado?

No que tange ao tema das relações econômicas entre os TPO e mercados externos, como discutido anteriormente, o Banco se tornou um forte defensor da liberalização comercial e financeira ao longo dos anos 1980, e não surpreende que suas prescrições para os territórios palestinos tenham seguido diretrizes similares no início da década seguinte. No volume de “visão geral" dos estudos de 1993, a discussão sobre comércio se inicia nos seguintes termos:

No que tange às relações com o mundo externo, em termos econômicos, a opção de se voltar para dentro seria claramente muito custosa para uma economia pequena como a da Cisjordânia e Gaza. Significaria imensas perdas de eficiência e um declínio significativo nos padrões de vida. Se é para a economia atingir desenvolvimento sustentável, a abertura de mercados externos para exportações dos OT é importante (BANCO MUNDIAL, 1993a, p.13).

Assim, imediatamente após iniciar a discussão sobre este conjunto de escolhas estratégicas a serem feitas pelas lideranças palestinas, o volume 1 do relatório coloca como inviável uma das opções disponíveis: "se voltar para dentro". Estabelece-se rapidamente um único horizonte possível: construir uma economia aberta e orientada para a exportação. É no segundo volume dos estudos, contudo, que se apresenta de maneira aprofundada a discussão sobre os futuros padrões de comércio dos TPO. Neste volume, um padrão semelhante de argumentação pode ser observado. O primeiro capítulo é voltado a um resumo do volume e, ao abordar a questão do comércio, indaga: 
Que abordagem deveria ser adotada em relação à direção da atividade econômica? A Cisjordânia e Gaza possuem, em princípio, uma gama de escolhas, do livre comércio com os países vizinhos à gestão de um regime de importações muito mais fechado para tentar impulsionar indústria doméstica (BANCO MUNDIAL, 1993b, p.4).

Em seguida, são apresentados os “dois princípios guias” das conclusões do Banco sobre o tema, aprofundados no capítulo 3 desse segundo volume dos relatórios. Como primeiro princípio, o Banco afirma que "o pequeno tamanho e a localização da Cisjordânia e Gaza apoiam fortemente a conveniência de uma estratégia baseada na expansão do comércio, e não em sua restrição" (BANCO MUNDIAL, 1993b, p.4). O fato de que a ausência de controle sobre fronteiras poderia "apoiar fortemente" a necessidade de estratégias alternativas, não centradas na exportação, não é sopesado pela análise do Banco. O segundo princípio guia afirmava que "qualquer corte súbito no comércio de bens com Israel poderia levar a grandes custos no curto prazo" (BANCO MUNDIAL, 1993b, p.5), de forma que a diversificação do comércio prescrita aos TPO não deveria passar por rompimentos nas relações comerciais com Israel.

É após estas exposições iniciais e resumidas, citadas parcialmente acima, que o estudo do Banco passa a avaliar de forma mais aprofundada diferentes possibilidades de arranjos comerciais futuros. No terceiro capítulo do volume 2 dos estudos, denominado "Escolhas estruturais de policy para o futuro", é oferecido um modelo gravitacional de comércio internacional, buscando explicar os padrões esperados no comércio da região caso barreiras então presentes fossem retiradas. Baseado em variáveis como o peso das economias, a distância entre elas, e eventuais proximidades (linguística, por exemplo), é o modelo gravitacional que informa ao Banco os dois "princípios guias" expostos acima. Por um lado, constata-se que o predomínio de Israel como parceiro comercial é artificial, e que os TPO deveriam estar muito mais conectados com vizinhos como a Jordânia e o Egito do ponto de vista econômico. Este achado embasa o princípio de que os territórios deveriam expandir suas trocas com a região. Por outro lado, o modelo também prevê grandes perdas econômicas aos palestinos caso algum corte brusco do comércio com Israel viesse a ser implementado, o que embasa a posição defendida de buscar manter laços comerciais preferenciais com os mercados israelenses.

Após explorar diferentes possibilidades de liberalização no modelo gravitacional elaborado, e observar os padrões de exportação e importação dos TPO/Israel para cada uma delas, o relatório se volta às "Escolhas de Policy Comercial" (BANCO MUNDIAL, 1993b, p.47) disponíveis aos palestinos. O texto não nega que estas escolhas estavam "altamente restritas" (BANCO MUNDIAL, 1993b, p.48) por constrangimentos políticos, mas ao mesmo tempo afirma a existência de "uma desconcertante gama de escolhas" (BANCO MUNDIAL, 
1993b, p.48) perante os formuladores de política palestinos. De qualquer forma, o relatório em seguida expõe "algumas das alternativas que em princípio poderiam se tornar disponíveis" (BANCO MUNDIAL, 1993b, p.48), e afirma que elas

“[...] deveriam ser avaliadas com respeito a quatro objetivos:

construir na base do estabelecido e principal mercado de Israel;

a busca agressiva de novos mercados (na região e em outros lugares);

movimento em direção a estrutura mais racional de preço do que hoje prevalece, em grande parte importada do regime de incentivos de Israel, e

o ímpeto de longo prazo para crescimento e desenvolvimento" (BANCO MUNDIAL, 1993b, p.48).

Diante dos critérios estabelecidos acima, é difícil imaginar como uma outra estratégia que não pautada na liberalização - pudesse ser bem avaliada pela análise do relatório. É após afirmar tais critérios que diferentes cenários comerciais possíveis passam a ser examinados. Dentre as possibilidades, aventam-se o estabelecimento de uma área de livre comércio com Israel e a manutenção de uma união aduaneira parcial com o país. Os mesmos cenários são avaliados em relação à Jordânia, e ainda um cenário em que os TPO mantivessem tanto um acordo preferencial com Israel - é dado destaque a uma área de livre comércio - quanto uma abertura significativa para outros vizinhos. Este cenário de dupla abertura é, previsivelmente, recomendado pelo relatório acima de qualquer outro. Dois cenários de política protecionista são avaliados por último - um moderado e um radical. Os custos do protecionismo industrial são destacados, bem como os riscos de cooptação por setores interessados (rent-seeking), de financiamento de atividades ineficientes, de perda do mercado israelense e de "[p]ossível retaliação por Israel” (BANCO MUNDIAL, 1993b, p.51).

Após avaliações de vantagens e desvantagens, na conclusão do capítulo o relatório se permite indagar "[q]ual abordagem é melhor?". A primeira conclusão, em repetição aos princípios afirmados no volume 1 , bem como no capítulo 1 deste mesmo volume, é de que "uma estratégia geral apropriada é maximizar novas oportunidades de comércio sem causar grandes perdas no mercado principal de Israel”. As recomendações contra o protecionismo são também retomadas, de forma conclusiva: "experiência internacional levanta vários sinais de aviso sobre perseguir uma política industrial ativista, como tarifas altamente diferenciadas; amplo apoio para exportações provavelmente faz mais sentido" (BANCO MUNDIAL, 1993b, p.55). 
$\mathrm{Na}$ concepção defendida, a liberalização comercial garantiria o fortalecimento da economia e a elevação da renda nos territórios, uma vez que permitiria acesso a mercados consumidores muito maiores do que aquele representado pela população palestina dos TPO. Do lado da oferta, a abertura às importações de países como Jordânia e Egito permitiria acesso a materiais de produção mais baratos do que aqueles até então obtidos no mercado israelense, impulsionando a competitividade da produção palestina. Assim, de acordo com o Banco,

[a] abertura do comércio com Jordânia, Egito e o resto do mundo árabe permitiria aos TO diversificar sua base de exportações, consequentemente reduzindo sua vulnerabilidade a choques externos (BANCO MUNDIAL, 1993a, p.14).

Como será abordado no capítulo seguinte, a diretriz de liberalização comercial foi o que esteve por trás da iniciativa de estabelecer zonas industriais nos territórios. Localizadas na fronteira com Israel, o objetivo das zonas industriais era produzir para exportação e, com isso, gerar empregos e renda a nível local. Mais do que isso, como se percebe no trecho acima, a produção para exportação permitiria, segundo o relatório, maior independência à economia da Cisjordânia e da Faixa de Gaza, que estariam menos vulneráveis com a diversificação de parceiros comerciais. Contudo, deve-se insistir em que a construção de uma economia calcada no comércio externo pressupõe a garantia de controle sobre território, fronteiras e movimentos de bens e pessoas - em suma, pressupõe soberania. O estudo do Banco, embora mencione a questão de controle sobre fronteiras, compreende que se trata de um problema cuja solução depende do andamento dos processos políticos, e sobre o qual nada se poderia fazer. Contavase, em outras palavras, com um cenário futuro em que Israel e a OLP houvessem atingido um acordo garantindo a regularidade dos fluxos comerciais entre os TPO e o exterior. É assumindo esse cenário que o estudo julga a eficiência de cada estratégia de política comercial e defende a maior liberalização possível.

\subsubsection{Financeirizando os territórios ocupados}

Para além da abertura comercial, a liberalização financeira também é apontada ao longo do estudo como fundamental para o desenvolvimento sustentável da economia dos territórios palestinos. O tópico "Desenvolvimento do Setor Financeiro" está incluído entre os imperativos institucionais e de política pública do primeiro volume (BANCO MUNDIAL, 1993a, p.19), e é aprofundado no terceiro volume dos estudos (BANCO MUNDIAL, 1993c, p.70), este centrado no desenvolvimento do setor privado. No primeiro volume, o tópico se inicia com a seguinte descrição geral:

O enquadramento legal e regulatório atual, um retalho de legislações jordaniana, egípcia, do mandato britânico e israelense, não é propícia à expansão de instituições 
financeiras existentes ou ao estabelecimento de novas (BANCO MUNDIAL, 1993a, p.19).

Uma interpretação diferente poderia surgir de uma leitura mais pausada do “Desenvolvimento do Setor Financeiro desde 1967”, que dá nome à seção de um dos anexos do volume terceiro dos relatórios (BANCO MUNDIAL, 1993c, p.71):

Quando da Guerra Árabe-Israelense em junho de 1967, havia 8 bancos jordanianos e estrangeiros, com 26 filiais, na Cisjordânia, e bancos egípcios e estrangeiros, com 4 filiais em Gaza. Aqueles na Cisjordânia (administrada pela Jordânia) operavam sob a Lei Bancária Jordaniana de 1965, enquanto aqueles em Gaza (administrada pelo Egito) operavam sob a ordenança bancária de 1941, estabelecida pela autoridade britânica do mandato. O exército israelense fechou todos os bancos árabes e estrangeiros imediatamente após sua conquista da Cisjordânia e de Gaza, congelou suas contas e transferiu seus saldos de caixa ao Banco Central de Israel como contas de depósito em nome do banco. A moeda israelense foi declarada a moeda corrente nos TO e regulações de controle de câmbio israelenses, muito mais restritivas que regulações ou práticas jordanianas, foram aplicadas (BANCO MUNDIAL, 1993c, p.71).

No trecho do anexo do volume 3 , fica muito mais evidente do que no volume geral a responsabilidade da ocupação como principal causa das restrições enfrentadas pelo setor financeiro dos TPO, no início dos anos 1990. Segundo o anexo, ainda, “[a]ntes de 1967, embora não fosse tão sofisticado pelos padrões atuais, o sistema bancário provia uma substancial intermediação financeira para a economia” (BANCO MUNDIAL, 1993c, p.72). Contudo, como visto acima, após a ocupação dos TPO a nova autoridade israelense proibiu a reabertura de bancos árabes que atuavam na Cisjordânia e em Gaza, assim como o estabelecimento de novas instituições financeiras voltadas a atender as populações palestinas (HEVER, 2010, p.10; SAYIGH, 1986, p.50). Apenas bancos israelenses passaram a operar nos territórios. Embora a maioria estivesse voltada a prover serviços a colonos, em 1984 havia 22 filiais de bancos israelenses em cidades palestinas, com "práticas de empréstimo mais agressivas" (BANCO MUNDIAL, 1993c, p.72 - grifo nosso).

No terceiro volume, o anexo voltado ao desenvolvimento do setor financeiro, além de examinar os incentivos à atuação de bancos comerciais nas últimas décadas, analisa também outros serviços financeiros disponíveis nos TPO após 1967. Exemplo são os "Programas de Crédito" ${ }^{64}$ que se desenvolveram, diante da "falta de um mecanismo efetivo para mobilizar

\footnotetext{
${ }^{64}$ Além dos programas de crédito, são analisadas as casas de câmbio - em grande parte informais ou ilegais - que se multiplicaram após 1967 nos TPO, em parte como resposta às novas restrições impostas ao setor financeiro. O relatório aponta que os serviços prestados se centravam na realização de transações internacionais e operações de
} 
poupanças e prover crédito nos TO” (BANCO MUNDIAL, 1993c, p.82). Estes programas visavam, em geral, contribuir para objetivos de desenvolvimento e bem-estar social, tendo como principal foco a assistência à pequena empresa. Eram geridos sobretudo por ONGs, palestinas e estrangeiras (BANCO MUNDIAL, 1993c, p.82). A avaliação do Banco sobre os programas de crédito existentes é de que eles

[...] oferecem capital muito barato, dados seus altos riscos em emprestar para pequenas e médias empresas (PME), o que está em profunda diferença em relação a políticas bancárias de empréstimos a PME normais, ajustadas ao risco, tanto em países em desenvolvimento quanto desenvolvidos ${ }^{65}$ (BANCO MUNDIAL, 1993c, p.82).

O relatório avisa que os programas estão oferecendo crédito a "taxas de juros abaixo do mercado - até 50\% menos - e em geral melhores termos aos empréstimos mais arriscados" (BANCO MUNDIAL, 1993c, p.83). É ressaltada a insustentabilidade financeira de tais padrões. Ademais, afirma-se que estas "práticas de empréstimo "suaves"” teriam incentivado a criação de "um ambiente em que os programas de crédito são constantemente vistos mais como caridade ou como uma bolsa politicamente motivada do que como uma transação de negócios" (BANCO MUNDIAL, 1993c, p.83). A solução apontada, além de mais coordenação entre as grandes provedoras de serviços financeiros, está em "fortalecer a gestão financeira nos programas" e implementar "práticas de empréstimo mais disciplinadas" (BANCO MUNDIAL, 1993c, p.83), o que, pressupõe-se, envolveria aumentar as taxas de juros sobre os empréstimos realizados aos palestinos como forma de obter sustentabilidade e competitividade.

As soluções acima estão em sintonia com as diretrizes mais gerais, apontadas pelo Banco como condição para o desenvolvimento apropriado do setor financeiro nos TPO. Segundo o estudo, haveria quatro elementos cruciais a serem abordados:

[a] regulações e práticas prudenciais unificadas para o setor bancário, baseada em prática internacional adequada; [b] estabilidade, solvência e liquidez do sistema bancário; [c] supervisão de bancos (e outros intermediários financeiros) operando nos TO; [d] expansão de bancos existentes e o estabelecimento de novos (BANCO MUNDIAL, 1993c, p.92).

câmbio, sendo mínimos os montantes oferecidos em crédito para investimento. Assim, o relatório destaca que a existência desses serviços financeiros não substituía a necessidade de desenvolver "um setor bancário eficiente" nos territórios, capaz de estimular o investimento privado (BANCO MUNDIAL, 1993c, p.82). O estudo examina ainda a existência de serviços de seguro nos territórios: até 1993, somente uma agência de seguros operava nos TPO, com sede em Nablus, e era considerada pelo estudo como "apenas um provedor modesto de capital à economia dos OT” (BANCO MUNDIAL, 1993c, p.83).

65 “Uma taxa de juros média de 5\%, incluindo taxas, em dólares” BANCO MUNDIAL, 1993c, p.82. 
A estratégia adequada para atingir tais objetivos, na concepção do Banco, era o estabelecimento de um enquadramento regulatório unificado e independente para as atividades financeiras na Cisjordânia e em Gaza, em sintonia com os padrões internacionais de gestão de crédito. A ênfase da reforma prescrita é clara:

[o] passo mais importante para reativar o setor financeiro seria encorajar a operação de bancos bem capitalizados, com gestão experiente, que fossem autorizados a competir livremente, com um conjunto de regulações bancárias claramente articulado (BANCO MUNDIAL, 1993c, p.94).

Complementando o sistema bancário comercial que emergiria, considera-se adequada a criação de um banco de investimento "fortemente capitalizado, em propriedade e controle do setor privado" (BANCO MUNDIAL, 1993c, p.101), dotado de "estrita disciplina fiscal" (BANCO MUNDIAL, 1993c, p.100) e um portfólio balanceado de investimentos de curto e longo prazo. Sobre a possibilidade de estabelecimento de um mercado de ações nos TPO, o relatório identifica a existência de 38 empresas de sociedade anônima operando em 1993 na Cisjordânia e em Gaza (sob leis diferentes, a depender da jurisdição), cujas ações eram comercializadas de maneiras relativamente informais. Aponta-se, como efeito, a ausência de informação suficiente sobre os valores trocados, mas afirma-se que existe uma demanda das empresas por

[...] medidas para ampliar a estrutura de propriedade para explorar os altos níveis de liquidez e para tirar vantagem da natureza livre de impostos dos ganhos sobre capitais e dividendos nos TO (BANCO MUNDIAL, 1993c, p.102).

Diante da demanda identificada, o Banco sugere que,

[p]ara servir ao objetivo de longo prazo de crescimento do mercado, deveria haver um enquadramento legal mais objetivo e claramente definido, que equilibre desenvolvimento do mercado com alguma supervisão regulatória para garantir troca justa e eficiente e proteger os interesses dos acionistas (BANCO MUNDIAL, 1993c, p.102).

Além do enquadramento regulatório adequado, um "mecanismo de saída eficiente" como um mercado de ações é sugerido. São apresentadas tanto a opção de se integrar ao mercado financeiro de Amam quanto de desenvolver um mercado independente.

A principal conclusão do Banco sobre o desenvolvimento do setor financeiro nos TPO é a necessidade de "Endurecer as Políticas de Empréstimo para Fortalecer os Programas de Crédito”. Num balanço das práticas de crédito das últimas décadas, o relatório afirma que as agências palestinas e externas "ofereceram financiamento a um amplo espectro de projetos economicamente viáveis, pessoas necessitadas e grupos desfavorecidos na sociedade palestina" 
(BANCO MUNDIAL, 1993c, p.104). No entanto, a baixa recuperação de crédito teria levado os emprestadores atuantes nos TPO a buscarem "uma abordagem mais disciplinada" (BANCO MUNDIAL, 1993c, p.104).

Contudo, as taxas de juros cobradas são ainda pesadamente subsidiadas e, embora existam objetivos políticos nesses programas, esse empréstimo subsidiado parece ter tido um impacto negativo na disciplina de crédito na economia dos TO, mesmo que esses programas sejam pequenos no agregado (BANCO MUNDIAL, 1993c, p.104).

O relatório defende três medidas para incentivar a disciplina de crédito. Em primeiro lugar, estabelecer taxas de juros sintonizadas com os níveis de mercado. Em segundo, os empréstimos mais seguros não poderiam subsidiar aqueles mais arriscados. Por fim, sugere-se uma gestão conjunta do risco com os bancos comerciais, vistos como potenciais aliados em operações de recuperação de crédito (BANCO MUNDIAL, 1993c, p.104). O Banco ressalta que será necessária assistência técnica para o estabelecimento deste enquadramento regulatório e sistema bancário, e sugere a elaboração de um pacote de auxílio técnico para o desenvolvimento do setor bancário e do setor de securities (sugere, como alternativa possível, a provisão de dois pacotes, um para cada setor). $\mathrm{Na}$ conclusão, reafirma que a "estrutura ineficiente e duplicada de programas de crédito e instituições, de pequena escala e subsidiados, deveria ser reformada em direção a taxas de juros de mercado" (BANCO MUNDIAL, 1993c, p.106).

Fica evidente, nessas prescrições, como o Banco Mundial impulsionou uma estruturação do sistema financeiro dos TPO altamente voltada ao mercado, primando pela competitividade nas taxas de juros - isso é, aumento das mesmas - e participação central do grande capital internacional (e proteção dos interesses de acionistas destes). Não há, nos estudos, qualquer priorização à necessidade de crédito barato às populações palestinas dos territórios, nas condições em que se encontrava no início dos anos 1990.

\subsubsection{O papel dos setores público e privado palestinos nos TPO}

Numa expressão dos objetivos gerais que animavam as ações do Banco Mundial nos territórios palestinos, com o início dos "processos de paz", Abdallah Bouhabib (1994, p.69) afirmava:

No momento há muito entusiasmo em apoiar uma entidade palestina ou povo palestino - mas daqui a cinco anos este pode não ser o caso, especialmente dada a fadiga na ajuda, que está emergindo por todo o mundo. Há a oportunidade aqui, que não deveria ser perdida, de ajudar a construir uma economia baseada no setor privado como principal motor do crescimento. 
Segundo Bouhabib (1994, p.68), o Banco Mundial considerava que um programa de desenvolvimento ou investimento possui dois objetivos principais: melhorar a qualidade de vida das populações envolvidas e construir "o ambiente certo" para que o setor privado seja incentivado a participar. Como visto, a diretriz estava em sintonia com posições antigas do Banco Mundial, que sempre aproximou desenvolvimento de crescimento econômico e sempre afirmou este como função sobretudo da atuação do setor privado.

As diferenças observadas na posição do Banco, no que tange aos TPO, estão em nuances advindas das especificidades do contexto local. O estudo de 1993 afirma, na contramão das tradicionais posições da instituição, que

[h]averá uma necessidade de um fortalecimento substancial da ação pública em muitas áreas, incluindo gestão macroeconômica, administração tributária, o enquadramento regulatório e a supervisão do sistema bancário (BANCO MUNDIAL, 1993a, p.13).

É expressiva a concepção de que a ação pública precisava ser "fortalecida", tendo em vista que, até então, os palestinos não tinham qualquer entidade governamental para fortalecer, além da Administração Civil da ocupação israelense e das municipalidades. O Banco não parece fazer distinção significativa entre a natureza da futura entidade palestina e a AC: ambas são consideradas, para períodos diferentes, o lócus fundamental da gestão pública, isto é, o "setor público" em si, sem que qualquer diferença substantiva entre as duas seja ressaltada - para além do "tamanho" de suas estruturas. A ação pública nos TPO, assim, não precisava ser construída a partir do zero, mas fortalecida como continuidade de estruturas anteriores. A priorização do setor privado destacada acima, portanto, é articulada à necessidade (temporária) de aumento do tamanho do aparato governamental.

Essa necessária expansão das estruturas estatais, diagnosticada pelo estudo, é considerada fruto "dos desequilíbrios econômicos existentes e das necessidades sociais não atendidas" (BANCO MUNDIAL, 1993a, p.13). O setor público teria uma função importante nos primeiros anos, sendo responsável por garantir "infraestruturas físicas e sociais, uma prioridade chave para melhorar padrões de vida da população e para estimular o desenvolvimento do setor privado" (BANCO MUNDIAL, 1993a, p.13), cujos investimentos seriam, num primeiro momento, pouco atraídos pelas difíceis e incertas condições dos territórios. Assim, percebe-se que o objetivo final de um bom funcionamento do setor público palestino está, precisamente, no incentivo que ele representaria ao setor privado:

Uma função ainda mais crucial para o setor público seria prover um ambiente de negócios encorajador, dentro do qual o setor privado pudesse florescer, ao mesmo 
tempo protegendo interesses públicos em áreas como saúde, segurança e o meio ambiente (BANCO MUNDIAL, 1993a, p.13.).

Após indicar a necessidade de um setor público relativamente grande para os padrões do Banco, o estudo imediatamente inicia um longo aviso de precaução, afirmando ser "essencial que o setor público não seja sobrecarregado" (BANCO MUNDIAL, 1993a, p.13).

Em particular, qualquer envolvimento do setor público em empreendimentos diretamente produtivos, ou interferência no mercado apoiando atividades inviáveis do setor privado (por exemplo, através de controle de preços e limitação da concorrência), retardariam o desenvolvimento econômico e, portanto, deveria ser resistido. A experiência internacional indica que padrões diferenciados de proteção, política de ativismo industrial ou canalização pública de dinheiro em empreendimentos inviáveis através do sistema financeiro muito frequentemente levam a desastre econômico. Economias que prosperaram no passado se basearam primariamente no setor privado, trabalhando em mercados não distorcidos, como motor primário do crescimento econômico (BANCO MUNDIAL, 1993a, p.13).

Fica evidente, assim, a posição do Banco, em 1993, sobre os tamanhos e funções relativos do setor público e privado palestino. O primeiro, como visto, é compreendido antes de mais nada como um agente do fortalecimento do segundo, um garante de seu desenvolvimento adequado. Por sua vez, é este desenvolvimento do setor privado que permitirá atingir níveis sustentáveis de crescimento e, consequentemente, de desenvolvimento socioeconômico para as populações dos TPO.

O trecho acima contém, ainda, duas características presentes em outras partes do relatório que merecem ser destacadas. A operação de embasar prescrições na "experiência internacional", sem elaborações mais profundas, é frequente ao longo dos seis volumes do estudo. O mesmo acontece com este movimento de, por um lado, prescrever a necessidade de expansão do setor público e, por outro, conectar tal prescrição a avisos enfáticos contra os perigos de que a expansão pública seja excessiva e irresponsavelmente realizada. Tais estratégias argumentativas aparecem, por exemplo, na análise realizada pelos estudos sobre a gestão das estruturas e finanças públicas dos TPO, discutida a seguir.

\subsubsection{Construir para reformar}

Diante da tarefa de estabelecer a nova entidade autônoma palestina, a questão do equilíbrio entre setores público e privado se refletia na escolha sobre como seriam constituídos os novos órgãos e agências responsáveis pelas infraestruturas físicas e econômicas dos territórios. No que tange à gestão de infraestruturas e serviços públicos, considerada entre os “Imperativos Institucionais e de Policy” identificados pelo estudo, o Banco afirma que uma 
decisão prioritária dos formuladores de política palestinos será acerca da estrutura de propriedade predominante nas infraestruturas públicas a serem estabelecidas. Nesse ponto, sugere-se que,

[...] para prover uma base sólida para autonomia, accountability e eficiência, é recomendado que utilidades orientadas comercialmente sejam estabelecidas [...]. Isso não apenas proveria um enquadramento para autonomia empresarial e orientação comercial, mas também facilitaria privatização parcial ou total no futuro (BANCO MUNDIAL, 1993a, p.19).

Ao avaliar as necessidades de investimento em assistência técnica da futura entidade de governo palestino, o estudo volta a ressaltar que os serviços e estruturas providos pelo setor público têm como função principal a construção de ambiente adequado ao setor privado, e devem existir somente enquanto não puderem ser substituídos por investimentos deste. "Ainda assim, onde possível, os investimentos devem ser desenhados de maneira a facilitar privatização em uma data futura" (BANCO MUNDIAL, 1993a, p.23). Fica explicitada, novamente, o caráter temporário das prescrições para expansão do setor público, e alicerça-se a compreensão de que o único caminho a ser seguido é no sentido de sua diminuição futura por meio de privatizações.

As questões abordadas acima, sobre o tamanho relativo da futura entidade palestina, estão igualmente presentes na discussão sobre a gestão das finanças públicas dos territórios, também incluída como um "Imperativo Institucional e de Policy”. O estudo inicia o tópico sobre finanças públicas recorrendo, novamente, à "experiência internacional" como fonte de autoridade que "sugere que estabelecer um sistema de finanças públicas sólido na Cisjordânia e em Gaza será necessário para criar um ambiente favorável ao desenvolvimento do setor privado e à atração de assistência externa” (BANCO MUNDIAL, 1993a, p.17).

Para organizar as finanças públicas dos TPO, o Banco aponta a necessidade de expansão da base tributária e de racionalização da arrecadação, por meio do estabelecimento de "regras transparentes" (BANCO MUNDIAL, 1993a, p.17), de "um mecanismo institucional crível e eficiente de solução de disputas tributárias" (BANCO MUNDIAL, 1993a, pp. 17-18) e da consolidação de atividades de auditoria e contabilidade. A questão das transferências fiscais entre Israel e a nova entidade também é abordada, e o estudo ressalta a importância de que um acordo seja atingido para regularizar a situação - tendo em vista que, até então, a arrecadação de impostos era feita pela Administração Civil da ocupação e parte dos impostos tinha como destino o tesouro israelense (BANCO MUNDIAL, 1993a, p.18). O Banco recomenda, ainda, que serviços públicos providos - como água, eletricidade, descarte de lixo sólido e comunicações - sejam cobrados dos usuários, de forma que as "entidades autônomas 
comercialmente orientadas", responsáveis por esses serviços, tenham "suas operações financeiramente viáveis, sem a necessidade de qualquer apoio orçamentário" (BANCO MUNDIAL, 1993a, p.18).

Após abordar a arrecadação, o estudo analisa o "lado das despesas", e ressalta a importância de "equilíbrio" e "sustentabilidade". Novamente delimitando as funções do setor público, afirma-se que entre os serviços e infraestruturas providos por ele deveria estar "uma limitada e bem direcionada rede de proteção para os segmentos mais pobres da população" (BANCO MUNDIAL, 1993a, p.18). Imediatamente em seguida, o estudo inicia enfáticas recomendações por precaução nos gastos:

Deve-se tomar cuidado para não se ampliar indevidamente a burocracia do setor público, e este não deve atuar como o empregador residual. O período pós-paz poderia testemunhar grandes pressões para gastos públicos maiores [...]. O provável relaxamento temporário nas restrições ao financiamento, na sequência de um acordo de paz, poderia mascarar por alguns anos políticas de gasto e empréstimo imprudentes. Controle forte e conservador será, assim, importante para evitar níveis insustentáveis de gastos, que seriam difíceis de reverter no futuro (BANCO MUNDIAL, 1993a, pp. 18-19).

Sobre a criação de uma rede de proteção social, citada acima, o estudo elabora prescrições mais detalhadas ao abordar os serviços sociais em que o setor público será necessário, como saúde e educação. Partindo do diagnóstico de que "[r]ecursos para sustentar um programa de bem-estar social abrangente dificilmente se tornarão disponíveis [...] no futuro próximo" (BANCO MUNDIAL, 1993a, p.20), o estudo esboça um "programa básico de proteções sociais" destinado a "deficientes, idosos, órfãos e viúvas". Logo em seguida, é reforçado o aviso de que este programa "não deveria visar substituir o apoio em transferências privadas e poupanças pessoais" como principal fonte de segurança financeira da população. Ademais, o estudo recomenda, como parte da solução para promover tal segurança social, que a nova autoridade "deveria também encorajar o desenvolvimento de instituições privadas que ofertem serviços financeiros, incluindo empresas de seguro saúde e de vida, bem como esquemas de pensão" (BANCO MUNDIAL, 1993a, p.20). Buscando evitar que os gastos públicos se elevem mais do que o desejado, assim, o Banco Mundial aponta o desenvolvimento do setor financeiro e do endividamento privado como receita para garantir segurança social à população palestina no longo prazo.

Como visto, o receio do alargamento excessivo do setor público, nas posições e políticas do Banco Mundial ao longo de sua história, concretiza-se na condenação do endividamento 
público como "gasto indevido". Para os TPO, contudo, este diagnóstico parece descabido, tendo em vista que a nova entidade governamental ainda sequer havia sido criada. O estudo reconhece esta condição fiscal inicial, considerando-a um dos aspectos mais positivos para o desenvolvimento futuro dos territórios. As consequências apontadas de tal condição fiscal, no entanto, valem observação mais cuidadosa:

[...] diferentemente da maioria das outras economias em desenvolvimento, os TO não
têm que lidar com o fardo de uma dívida externa esmagadora. Finanças públicas [...]
estão próximas do equilíbrio, e não há nem uma burocracia inchada, nem uma empresa
pública que gere prejuízo. Livre destes legados, a política pública pode, assim, focar
em reforma estrutural. Isso também significa que a economia dos TO pode sustentar
uma certa quantidade de empréstimos externos, especialmente para melhorar
infraestruturas públicas essenciais. Condições macroeconômicas sólidas podem, no
entanto, ser rapidamente perdidas por políticas imprudentes, especialmente no setor
público (BANCO MUNDIAL, 1993a, p.12).

Como discutido anteriormente, as políticas de ajuste estrutural surgiram, na história do Banco Mundial, como resposta a altos níveis de endividamento externo dos países em desenvolvimento. A exigência de reformas estruturais nestes países - a prescrição de cortes de gastos públicos, privatizações, liberalização comercial e financeira, e assim por diante - tinha como objetivo central declarado o combate à dívida externa. Buscava-se, em outras palavras, reformar as estruturas e práticas governamentais no intuito de torná-las financeiramente eficientes e sustentáveis. A prescrição do estudo, presente acima, parece seguir uma lógica oposta. A reforma estrutural no setor público palestino é apresentada como necessária mesmo diante do equilíbrio nas contas públicas e da ausência de endividamento. Mais do que isso, o Banco sugere que, precisamente por estar livre dos legados do endividamento, os territórios palestinos poderiam se lançar a reformas de maneira mais simples e imediata. Em suma, já em meados de 1993, antes mesmo da autoridade palestina ser criada, o Banco Mundial já previa e prescrevia a necessidade de reformá-la estruturalmente.

\subsection{Limites e contradições da assistência externa: primeiras avaliações}

As diretrizes apresentadas nos estudos de 1993 foram, em grande medida, transformadas em pacotes de auxílio a projetos de desenvolvimento implementados na Cisjordânia e Faixa de Gaza, ao longo da década seguinte. Imperativos de priorização do setor privado e orientação ao mercado (de preferência externo) tornaram-se marca comum destes projetos, como será discutido mais lentamente no próximo capítulo, sobre a primeira zona industrial voltada à 
exportação implementada no contexto dos "processos de paz". O desenvolvimento do setor financeiro também pôde ser observado nas décadas que se seguiram ao início dos processos (NAHKLEH, 2012), ocorrendo em sintonia com as prescrições de liberalização financeira já presentes nos estudos do Banco - em suma, abertura à competição nos serviços financeiros, e consequente ajuste das taxas de juros de acordo com padrões internacionais de lucratividade.

A crítica à atuação da assistência financeira internacional nos territórios palestinos ocupados, ao longo dos anos 1990, frequentemente enfatiza temas como a velocidade de liberação dos fundos e de implementação dos projetos, a difícil coordenação entre agências e governos doadores, e destes com os órgãos palestinos que foram sendo criados a partir de 1994. No que tange à demora no desembolso dos valores prometidos, bem como na implementação dos projetos, líderes palestinos criticaram o atraso como forma de pressão política por parte da comunidade doadora. De fato, como citado, existia receio entre os financiadores de que os gastos da ANP se tornariam permanentemente dependentes do financiamento externo. Outros descompassos eram criticados, e apontavam-se suas consequências negativas para o desenvolvimento socioeconômico dos TPO. Por exemplo, foi marcante a discrepância entre a predisposição dos doadores por financiar amplos projetos, voltados para o longo prazo, e a necessidade afirmada pelas lideranças palestinas de rápida implementação, para sustentar o processo político em andamento (BRYNEN, 1996b, p.80). Como abordado, ajustes foram sendo feitos ao longo da década, principalmente diante de novos acontecimentos, com o objetivo de aprimorar a efetividade da assistência externa oferecida. Nesse sentido, o Banco Mundial buscou redirecionar montantes para projetos de curto prazo, por exemplo em momentos em que os fechamentos impostos por Israel nas fronteiras levaram a picos de desemprego. Da mesma forma, com intuito de adequar as práticas de assistência às realidades locais, a comunidade doadora estabeleceu estruturas de coordenação locais, como o Joint Liaison Committee e o Comitê de Coordenação Local de Ajuda, discutidos brevemente acima.

Essas avaliações críticas sobre a assistência externa aos TPO, contudo, não fogem do enquadramento estabelecido pelos "processos de paz". Em outras palavras, partem da premissa de que o auxílio internacional, conforme foi concebido, poderia ter dado certo, não fossem (i) problemas de ordem prática e operacional ou (ii) problemas de ordem política, cujas soluções estavam para além do controle da comunidade internacional e de seu escopo de ação. Cumpre, no entanto, realizar uma avaliação do auxílio externo aos TPO que não parta dos termos estabelecidos pela comunidade internacional ou pelos acordos de Oslo, mas que questione as premissas a partir das quais o esforço de ajuda foi concebido. No próximo capítulo, serão 
abordados alguns dos problemas práticos enfrentados pelos projetos de desenvolvimento, particularmente (mas não apenas) pela Zona Industrial de Gaza. Será argumentado que tais problemas possuem, em realidade, uma origem eminentemente política: a estrutura de ocupação colonial israelense e sua contínua soberania sobre os territórios palestinos. Antes disso, no restante deste capítulo, será enfatizado o segundo conjunto de problemas mencionados acima, estes declaradamente políticos, buscando avançar na contextualização histórica do esforço de assistência ao desenvolvimento aqui analisado. Trata-se, em outros termos, de avaliar a leitura frequente - feita pela comunidade internacional e por uma linha de análise alinhada com as diretrizes de Oslo - sobre como os acontecimentos políticos, nos anos que se seguiram a 1993, levaram a imensas dificuldades na tentativa de promover desenvolvimento socioeconômico nos TPO.

É frequente, em análises sobre a efetividade da assistência externa aos TPO, referências ao desando dos processos de paz nos anos que se seguiram à assinatura da Declaração de Princípios (BRYNEN, 2000; FRISCH; HOFNUNG, 1997; SLATER, 2001). Em novembro de 1995, o primeiro-ministro israelense Yitzhak Rabin foi assassinado por um israelense sionista radical, oposto às negociações com os palestinos. No início do ano seguinte, nos meses que antecederam eleições em Israel, os palestinos dos TPO realizaram a primeira eleição para a presidência da ANP e para o Conselho Legislativo Palestino (órgão legislativo da mesma). A ampla vitória do Fatah de Yasser Arafat chancelou, entre os palestinos dos territórios, a posição a favor dos "processos de paz" com os israelenses. Entre fevereiro e março de 1996, quatro ataques à bomba foram realizados em Jerusalém e Tel Aviv pelo grupo palestino Hamas, oposto à estratégia de negociações com Israel. A resposta de Israel foi a imposição do maior bloqueio ao movimento palestino já estabelecido sobre os TPO (BRYNEN, 2000, p.62). As eleições israelenses de maio foram marcadas pela campanha do Likud de Benjamin Netanyahu, eleito primeiro-ministro com uma agenda contrária aos "processos de paz" e explicitamente favorável à expansão dos assentamentos israelenses em territórios palestinos (BRYNEN, 2000, p.68). Com a nova coalizão liderada pelo Likud no governo israelense, as negociações em torno das questões de status permanente não foram iniciadas. A manutenção de políticas de restrição ao movimento - com suas consequências para a renda das famílias palestinas -, bem como uma política mais agressiva de construção de assentamentos desgastaram o apoio das populações palestinas aos "processos de paz". Aumentou, por outro lado, o apoio da população a ataques contra Israel, como forma de resistência às políticas impostas: se em março de 1996, quando dos ataques em Jerusalém e Tel Aviv, apenas $21 \%$ da população apoiava os atos, em abril do 
ano seguinte este número era de 40\%; e em outubro de 1998, 51\% dos palestinos apoiavam uma estratégia de combate armado contra o poder ocupante (BRYNEN, 2000, p.69).

A avaliação tradicional sobre a assistência externa aos TPO tende a enfatizar a sequência de acontecimentos descritos acima como fonte dos problemas políticos enfrentados pelas iniciativas de desenvolvimento impulsionadas. Concebida para auxiliar os "processos de paz", a assistência internacional não poderia funcionar sem que os processos políticos permitissem certas condições. Assim, a escalada de radicalismos - tanto do lado israelense quanto do palestino - teria inviabilizado a continuidade de negociações adequadas à solução do conflito e ao estabelecimento de trajetórias sustentáveis de desenvolvimento nos TPO (BRYNEN, 2000; FRISCH; HOFNUNG, 1997; SLATER, 2001). A ênfase nos eventos violentos de 1995 e 96, contudo, não explicita algumas dinâmicas observáveis desde antes disso. Em primeiro lugar, a política de restrição ao movimento palestino antecedia em décadas o governo Netanyahu, e desde a primeira Intifada havia se tornado bastante frequente na Cisjordânia e na Faixa de Gaza. Entre 1993 e 1994, particularmente, o número de dias por ano com bloqueio ao movimento havia mais que triplicado (BRYNEN, 2000, 64). Em segundo lugar, a discussão sobre assentamentos israelenses havia sido retirada da primeira rodada de negociações, e, além do partido conservador Likud, vários governos trabalhistas, como o do próprio Rabin, haviam dado continuidade à expansão colonial sobre os TPO, embora em diferentes ritmos (GORDON, 2008; PAPPE, 2006a; WEIZMAN, 2007)

A política relativamente constante de assentamentos israelenses insere-se num debate mais amplo, iniciado na introdução, sobre a natureza colonial da ocupação israelense sobre os TPO e sobre os reais interesses de Israel com os "processos de paz" do início dos anos 1990. Está para além do escopo deste trabalho realizar uma análise exaustiva das estratégias israelenses por trás dos acordos. Contudo, há evidências de que a soberania palestina sobre os territórios nunca esteve no horizonte estratégico de Israel, mesmo sob governos trabalhistas. Makovsky (apud HADDAD, 2016, pp.261-262) afirma, nesse sentido, que a visão do próprio Yitzhak Rabin para o futuro dos TPO passava por uma regulação conjunta entre soberanias israelense e jordaniana, sem independência real à entidade palestina. Dentre as reais estratégias israelenses por trás dos "acordos de paz", deve-se destacar a já mencionada busca por liberalização e por acesso aos mercados da região. Dois meses após a assinatura da DP, egípcios e israelenses assinaram um acordo para construção de um gasoduto entre os países. Da mesma forma, em outubro de 1994, Israel selou um acordo de paz com a Jordânia, normalizando relações comerciais com o país. Nesse sentido, Haddad (2016, pp.261-263) sugere, em diálogo 
com as afirmações feitas por Makovsky, que o acordo de Wadi Araba, com a Jordânia, talvez tenha sido a principal realização atingida por Israel com o início das negociações com os palestinos.

Se os "processos de paz" devem ser compreendidos a partir dos desenvolvimentos econômicos da década anterior - da "ambiciosa" trajetória de liberalização israelense, a nível regional, e também do avanço do neoliberalismo e da "nova ordem mundial", a nível global -, é importante que os efeitos da assistência externa e da atuação do Banco Mundial nos TPO sejam compreendidos a partir de termos semelhantes. Sem um horizonte real de soberania palestina, o principal efeito da assistência externa aos TPO parece ser a pacificação em chave neoliberal de uma população sob ocupação, isto é, a inserção desta população nas dinâmicas do capitalismo globalizado - como visto neste capítulo -, sem que esta mesma sociedade possua qualquer independência política real. O Banco Mundial, como explorado aqui, foi central na concepção dos termos nos quais se daria essa inserção palestina ao neoliberalismo: estabeleceu os padrões aceitáveis de uma entidade - mesmo que não soberana - no que tange à gestão de infraestruturas, serviços, finanças e comércio. Mais do que estabelecer marcos teóricos ao desenvolvimento dos TPO, contudo, o Banco participou da implementação de uma imensa variedade de projetos concretos. Cumpre, portanto, analisar também os efeitos destes projetos, dada a caracterização realizada acima sobre os reais horizontes abertos pelos "processos de paz”. É o que faz o próximo capítulo, através de um estudo de caso de um dos maiores projetos dos quais o Banco Mundial participou nos TPO, ao longo dos anos 1990: a Zona Industrial de Gaza. 


\section{CAPÍTULO 2: A ZONA INDUSTRIAL DE GAZA (1997-2007): NORMALIZAÇÃO ECONÔMICA E FALÊNCIA DA "PAZ"}

Desde o início dos "processos de paz", em 1993, até os dias atuais, projetos para o estabelecimento de zonas industriais voltadas à produção para exportação, na fronteira entre Israel e os territórios palestinos ocupados, tem frequentemente feito parte de planos para o desenvolvimento socioeconômico local - levados à cabo pela ANP, pelo grande empresariado palestino e por atores da comunidade de assistência internacional. A busca por cooperação entre capital palestino e israelense - com este normalmente ocupando posições superiores nas cadeias produtivas - é um objetivo comum destas iniciativas, que visam empregar a mão de obra palestina dos territórios. Fundamentalmente, estes projetos têm visado, desde 1993, contribuir para os "processos de paz" de forma mais ampla, gerando benefícios econômicos que impulsionem as perspectivas das negociações políticas - abaladas após 1996. Neste capítulo, analisa-se a história das iniciativas de zonas industriais nos TPO, localizando-as particularmente na história dos "processos de paz" e examinando, como um estudo de caso, a experiência da Zona Industrial de Gaza.

\subsection{A ideia de zonas industriais para exportação chega aos TPO (1989-1993)}

Nas últimas décadas, a iniciativa de promover zonas industriais voltadas para exportação, como parte de estratégias mais amplas de desenvolvimento socioeconômico, passou a ser uma característica comum em programas de assistência financeira para países em desenvolvimento. Embora a primeira destas experiências tenha se dado ainda nos anos 1940, com o estabelecimento de uma zona industrial em Porto Rico, é ao longo da década de 1970 que o modelo se popularizaria e seria exportado para diferentes países, tendo se proliferado de forma particularmente intensa após o fim da Guerra Fria, com a consolidação do neoliberalismo enquanto modelo paradigmático de desenvolvimento e sua marcante ênfase na produção para exportação (DANA, 2015, p. 468). Num contexto de crise de lucratividade e de progressiva internacionalização dos fluxos de capitais, as zonas industriais foram vistas como uma forma de absorção de capitais excedentes e um mecanismo para impulsionar a competitividade das economias do Sul Global ${ }^{66}$ (ADVANI, 2017, p.3).

\footnotetext{
${ }^{66} \mathrm{O}$ problema crônico de déficit de pagamentos, então enfrentado por boa parte dos países em desenvolvimento, tornou atrativa a ideia de zonas especiais para a exportação como forma de melhorar a competitividade das economias. Nesse sentido, sobre os efeitos econômicos das zonas, Advani $(2017$, p.4) afirma que "ao passo que elas podem ter atraído capital externo para reestruturar os déficits nas balanças de pagamentos, elas constantemente
} 
As zonas industriais são áreas destinadas à produção industrial na qual uma série de benefícios são oferecidos, visando à atração de investimentos domésticos e estrangeiros. Isenções fiscais, livre circulação de capitais e remessa de lucros, investimentos especiais em infraestrutura, acesso privilegiado a mercados internacionais e limitação de direitos trabalhistas são, geralmente, vantagens associadas ao estabelecimento de zonas industriais (ADVANI, 2017, p.2; DANA, 2015, pp. 468-69). O modelo, assim, estava em sintonia com o consenso neoliberal mais amplo do final do século passado, que prescrevia a desregulamentação do mercado e um modelo de desenvolvimento orientado para a exportação, sustentado num ambiente competitivo e atrativo para o setor privado em geral, e para o grande capital internacional em particular.

Nos territórios palestinos ocupados, a ideia de estabelecimento de zonas industriais para exportação emergiu, precisamente, no contexto de auge do neoliberalismo, com o fim da Guerra Fria e a expansão da influência norte-americana no Oriente Médio. Em geral, os interesses norte-americanos se centravam na estabilização política da região, visando sobretudo garantir a manutenção das ofertas de petróleo dos países do Golfo e a segurança para os investimentos norte-americanos. Assim, como discutido anteriormente, desde o fim dos anos 1980 ganhou força uma agenda para o Oriente Médio centrada em liberalizações econômicas e novas iniciativas de comércio - agenda esta impulsionada pelos EUA e por instituições financeiras internacionais como o Banco Mundial. Objetivo central, nessa agenda mais ampla, era normalizar as relações entre Israel e seus vizinhos árabes por meio do aprofundamento do intercâmbio econômico, ou, em outras palavras, quebrar o boicote dos países árabes às exportações israelenses (HADDAD, 2016, pp.261-263; SHAFIR; PELED, 2000). A adoção de políticas neoliberais pelo reino da Jordânia é exemplo disso: foi sobretudo com a assinatura do tratado de paz com Israel, nos anos 1990, que o governo e as elites jordanianas passaram a abraçar o neoliberalismo (KHALIDI; SAMOUR, 2011, p.11). A partir do final dos anos 1980, assim, o capital israelense passaria por um significativo processo de internacionalização, que andou, justamente, em paralelo com a busca por relações estáveis entre Israel e seus principais vizinhos (HANIEH, 2011).

Desde meados dos anos 1980, em Israel, o Partido Trabalhista abraçou a agenda de cooperação e integração econômica que os Estados Unidos tinham para a região. A principal expressão dessa adesão foi, como discutido na introdução, o "Novo Oriente Médio" idealizado

falharam em criar conexões fortes com o resto da economia local e em promover desenvolvimento nacional efetivo". 
por Shimon Peres (1993) - um local de paz, cooperação e prosperidade. Israel e os EUA ressaltavam os benefícios a serem obtidos de uma maior integração econômica regional e passaram a defender entre suas iniciativas, alguns anos antes dos "processos de paz", a criação de parques industriais voltados para exportação, que unissem os capitais israelense e palestino (ADVANI, 2017, pp.5-7; DANA, 2015). A liberalização e a globalização eram demandas centrais do setor privado israelense, que via nos mercados da região um potencial significativo e nas zonas industriais uma forma de atingi-los. Em suma, como discutido na introdução, desde meados dos anos 1980 a economia israelense buscava modernizar-se e voltar-se para a exportação, adequando-se aos padrões neoliberais de desregulamentação (GORDON, 2008; HANIEH, 2011; LAGERQUIST, 2003, p.9).

Será, portanto, nesse contexto de neoliberalização israelense que a iniciativa de zonas industriais será aventada pela primeira vez para os territórios da Cisjordânia e da Faixa de Gaza, alguns anos antes dos "processos de paz" serem iniciados. Com o início da Primeira Intifada, em 1987, Israel impôs políticas de restrição de movimento às populações palestinas dos territórios ocupados. Desde o início da ocupação, Israel havia mantido para os TPO uma "política de pontes abertas", permitindo o fluxo de palestinos pelas fronteiras. Como discutido, uma proporção significativa de palestinos passou a trabalhar em Israel. Assim, com a imposição de restrições nas fronteiras, em 1987, os níveis de desemprego na população palestina aumentaram significativamente, situação que se agravaria com o início da Guerra do Golfo, quando o fechamento das fronteiras por Israel se intensificou (LAGERQUIST, 2003).

Nesse contexto, por iniciativa do então ministro da defesa israelense Moshe Arens, iniciou-se a concepção de um plano israelense de desenvolvimento para os territórios ocupados que tinha, entre seus objetivos, o estabelecimento de uma Zona Industrial em Beit Hanoun, no lado palestino da fronteira entre a Faixa de Gaza e Israel. Arens encarregou Ezra Sadan, um economista neoliberal israelense, de conceber a criação da zona (NAKHLEH, 2012, p.94). Além de impulsionar o intercâmbio comercial com os países árabes e a internacionalização do capital israelense, a ideia por trás da estratégia israelense de desenvolvimento dos TPO era, como apontou o próprio Yitzhak Rabin,

[...] encontrar um equilíbrio entre ações que podem trazer terríveis problemas econômicos e uma situação em que [os palestinos] não tenham nada a perder, e medidas que os vinculem à administração israelense e previnam desobediência civil (RABIN apud LAGERQUIST, 2003, p. 7).

A iniciativa de zonas industriais buscava, em outras palavras, minimizar os efeitos que a limitação de movimentos estava gerando sobre a economia dos territórios, com o intuito, 
explicitamente apontado por Rabin, de pacificar a população palestina oferecendo-lhe empregos e uma condição de vida minimamente melhor. Isso seria feito garantindo que, independentemente da manutenção ou não das restrições ao movimento (que, de fato, se transformaram em política sistemática nos anos seguintes), os trabalhadores palestinos pudessem continuar sendo absorvidos pelo mercado de trabalho israelense sem, no entanto, terem de efetivamente cruzar a fronteira com Israel (LAGERQUIST, 2003, p.7). O próprio Ezra Sadan havia concebido a iniciativa de zonas industriais nas fronteiras entre os TPO e Israel como uma "solução de subcontratação" (HADDAD, 2016, p.130), que buscava substituir a migração diária de massas de trabalhadores palestinos por um esquema de subcontratos com empresas palestinas localizadas na zona (isso, claro, nos casos em que as próprias firmas israelenses não optassem por se instalar na zona). Resolvia-se, dessa forma, o "problema demográfico" de Israel, que, ao transferir e/ou terceirizar suas atividades produtivas através das zonas industriais, evitava a entrada diária de milhares de trabalhadores palestinos em seu território e, assim, via atendidas suas demandas por segurança (ADVANI, 2017, p.5).

Como se disse, as zonas industriais empregariam mão de obra palestina - mais barata que a israelense e previamente aprovada pelas forças de segurança de Israel - e garantiriam aos investidores incentivos fiscais, infraestruturas adequadas e fácil acesso aos mercados israelenses e internacionais. Em 1991, a primeira dessas áreas foi estabelecida em Beit Hanoun, cidade do nordeste da Faixa de Gaza que se situa na fronteira com Israel ${ }^{67}$, e cinco outras zonas semelhantes foram planejadas (DANA, 2015, p. 469; LAGERQUIST, 2003, p.7). As indústrias israelenses foram alocadas na zona industrial de Beit Hanoun pelas forças militares de Israel, e se mantiveram em estreita cooperação com as mesmas ao longo de todo o período em que a iniciativa se manteve.

Em apoio ao projeto, as forças israelenses decretaram em 1991 a "Ordem Militar 105”, que permitiu pela primeira vez o livre investimento em Gaza, limitado desde 1967. Ao mesmo tempo, a Administração Civil da ocupação passou a oferecer benefícios e subsídios a capitalistas palestinos da diáspora ${ }^{68}$, concedendo novas licenças e garantindo a eles, por exemplo, o direito de residência nos TPO. Como afirma Dana (2015, p.469), a Zona de Erez, como era conhecida a zona em Beit Hanoun, foi "a primeira vez que Israel buscou envolver o capital palestino da diáspora em investimentos conjuntos nas zonas industriais", embora as

\footnotetext{
${ }^{67}$ Comumente denominada Zona de Erez, em referência ao kibutz Erez localizado no lado israelense da fronteira. ${ }^{68}$ Termo utilizado para se referir a um empresariado palestino que, refugiado em 1948 ou 1967, construiu sua fortuna fora da Palestina, geralmente nos países da região (HANIEH, 2011).
} 
indústrias israelenses tenham ocupado os níveis mais altos das cadeias produtivas às quais o capital palestino foi integrado (NAKHLEH, 2012). Enquanto isso, desde 1989 a população palestina passou a ser objeto de políticas de controle e vigilância cada vez mais rigorosas, como a imposição de um sistema de identidades eletrônicas que posteriormente se generalizaria como método de monitoramento dos palestinos (LAGERQUIST, 2003).

De acordo com planejamentos iniciais do Ministério das Relações Exteriores israelense, a Zona Industrial de Erez empregaria cerca de 20 mil trabalhadores palestinos. No entanto, o número de empregos gerados nunca chegou a atingir nem um quarto deste valor (BAHOUR, 2010), e pode-se questionar até que ponto estes empregos representavam, de fato, uma contribuição ao desenvolvimento econômico da Faixa de Gaza. Na leitura de Advani (2017, p.5), por exemplo, as zonas industriais estabelecidas por Israel antes de Oslo apenas condensavam as principais características da economia palestina sob ocupação: "trabalhointensiva, subcontratada, voltada para a absorção de capitais excedentes de Israel e para a exportação para mercados israelenses, europeus e do Golfo".

Embora seja duvidoso que a zona industrial de Erez estivesse trazendo desenvolvimento - concebido de forma ampla - à Faixa de Gaza, para além de alguns milhares de empregos aos palestinos locais, é interessante observar o ponto de vista de um homem de negócios, palestino de Gaza, citado por Nakhleh (2012, pp. 94-95):

Os produtos de Erez tinham acesso livre a Israel, então para os palestinos era muito atrativo, porque não havia inspeção e dano aos produtos, ou atrasos. Além disso, as pessoas que trabalhavam em Erez podiam receber clientes israelenses.... Havia fábricas de plástico e outros produtos especializados que estavam sendo feitos em Gaza, mas de acordo com padrões israelenses.... As pessoas aprendiam muito com esses padrões, que eles aplicavam para Gaza, seja na forma de treinamento ou imitação. Os produtos projetados em Israel eram imitados e produzidos em Gaza, aumentando os padrões entre fronteiras. Mas quando Israel fechou suas fronteiras com Erez, [a zona] se tornou inútil, e agora está morta.

Após a assinatura dos acordos de Oslo, em 1993, o programa israelense de zonas industriais foi abandonado, embora a Zona de Erez tenha continuado funcionando até 2005, quando foi fechada como parte do plano de "desengajamento" de Israel em relação à Faixa de Gaza. De fato, dentre todas as iniciativas de zonas industriais para os TPO, a Zona de Erez foi a que mais tempo se manteve em funcionamento (BAHOUR, 2010). 


\subsection{As zonas industriais e os "processos de paz"}

No início dos anos 1990, a economia palestina estava profundamente deteriorada por anos de repressão à Primeira Intifada, pelo fechamento das fronteiras, pela expulsão de palestinos dos países do Golfo após a guerra, e sobretudo por uma ocupação que já durava 25 anos. Visando combater as difíceis condições econômicas - sobretudo o desemprego -, já durante as negociações, no início dos anos 1990, as discussões multilaterais sobre assuntos econômicos entre Israel, os EUA e os palestinos incluíam, entre as iniciativas aventadas, a ideia de um programa de zonas industriais estabelecidas nos territórios, em pontos de fronteira com Israel (LAGERQUIST, 2003, p.8).

O empresariado palestino, sobretudo composto por capitalistas da diáspora, desde o início se mostrou animado com a ideia de liberalização econômica em geral, e de zonas industriais para exportação em particular. Figuras importantes desse empresariado, assim, atuaram juntamente com os círculos centrais da ANP para impulsionar o processo (ADVANI, 2016; 2017; HANIEH, 2011). Os empresários palestinos, que haviam construído suas fortunas nos países da região, viram nos "processos de paz" uma oportunidade de participar do esforço internacional pela "paz" e pelo desenvolvimento dos TPO, ao mesmo tempo lucrando significativamente com isso. Mais que isso, vários destes empresários - que possuíam antigas ligações com Yaser Arafat ${ }^{69}$ - haviam sido cruciais para tornar os próprios "processos de paz" possíveis, facilitando sobremaneira as relações entre Israel/EUA e o que era, então, a OLP (NAKHLEH, 2012).

No período pós-acordos de Oslo, a economia palestina passaria por um marcante processo de "concentração de capital em poucos conglomerados centrais" (BOUILLON, 2004, p.45), os quais eram controlados "seja pela ANP, por oficiais da ANP, por palestinos ricos da diáspora com estreitas conexões com a ANP ou por uns poucos homens de negócios locais com ligações íntimas com a ANP” (ADVANI, 2016, p.74). A Palestinian Development and Investment Company (PADICO) é, certamente, o principal desses conglomerados. Fundada em 14 de outubro de 1993 - um mês após a assinatura da Declaração de Princípios - a PADICO é uma holding criada por alguns dos principais capitalistas palestinos da diáspora, notadamente por Munib al-Masri, homem mais rico da Palestina e cuja família está estreitamente envolvida com os esforços de desenvolvimento dos territórios (NAKHLEH, 2012, pp.74-75). Seu objetivo

\footnotetext{
${ }^{69}$ Munib al-Masri, figura discutida adiante, é o principal exemplo da proximidade entre o empresariado palestino da diáspora e a liderança da OLP. Disponível em: https://www.thedailybeast.com/munib-masri-remembers-yasirarafat-on-the-anniversary-of-his-death. Acesso em: 30.out. 2020.
} 
era investir nos TPO e "contribuir na construção da economia palestina por meio da implementação de uma diversidade de projetos de desenvolvimento em setores vitais da economia"70.

Por meio de holdings como a PADICO (e suas várias subsidiárias), o empresariado palestino da diáspora, impulsionado pela recém-criada ANP, garantiu participação central no esforço de desenvolvimento dos TPO discutido até aqui (HANIEH, 2011). No que tange ao programa de zonas industriais, especificamente, foi também a PADICO que liderou a iniciativa, criando uma subsidiária específica para o tema, que seria responsável pelo desenvolvimento e gestão do projeto piloto, em Gaza: a Palestinian Industrial Estates Development Company (PIEDCO) (BANCO MUNDIAL, 1997b).

A iniciativa de zonas industriais impulsionada pela elite política e econômica palestina se justificava, sobretudo, pela já mencionada deterioração da economia dos territórios nos anos que se seguiram à assinatura da Declaração de Princípios. Entre 1992 e 1998, o PIB per capita real caiu cerca de $21 \%$ na Cisjordânia e em Gaza. Particularmente agudos foram os declínios nas remessas de trabalhos em Israel, assim como a diminuição na produção agrícola. Os únicos setores em que se registrou crescimento significativo foram o de construção e de serviços públicos - os quais haviam se beneficiado do aumento na assistência externa e da criação da ANP. As exportações palestinas, entre 1992 e 1996, diminuíram em aproximadamente 23\%, e o investimento privado caiu cerca de 75\% (BRYNEN, 2000, p.63). Entre 1990 e 1995, o número de trabalhadores palestinos empregados em Israel havia diminuído significativamente, de $36,4 \%$ para $16,1 \%$ da força de trabalho palestina dos TPO (NAQIB, 2003, p.507). Essa redução foi causada, no entanto, pelos fechamentos de fronteira impostos por Israel, que impediam os palestinos de chegarem a seus trabalhos e deixavam explícita a completa dependência da economia dos TPO em relação à israelense. O enorme aumento na taxa de desemprego nesse período (de 3,7\% em 1990 para 18,2\% em 1995) indica, ainda, que em geral os empregos perdidos não haviam sido recuperados. $\mathrm{O}$ desemprego entre a população palestina atingiu 23,9\% em 1996, e no ano seguinte foi de 20,9\% (BRYNEN, 2000, p.63). A iniciativa de zonas industriais nas fronteiras, englobadas nos projetos de desenvolvimento mais amplos dos “processos de paz", surgia assim como uma solução ao desemprego destes palestinos que não podiam mais entrar em Israel. O projeto prometia atrair investimentos palestinos, israelenses e

\footnotetext{
${ }^{70}$ Disponível em: <https://www.padico.com/en/about-padico/overview〉. Acesso em: 27 jun. 2019.
} 
estrangeiros, gerando crescimento econômico e, sobretudo, empregos em uma economia profundamente abalada.

Para Israel, a racionalidade por trás da iniciativa, como parte dos "processos de paz", era semelhante àquela que animara o projeto da zona industrial de Erez, alguns anos antes. As zonas, além de desenvolverem e "pacificarem" os territórios, representavam uma solução ao problema das restrições de movimento impostas aos milhares de trabalhadores palestinos que atravessavam diariamente as fronteiras para trabalhar em Israel (LAGERQUIST, 2003, p.8; ROY, 1999). Mesmo que fossem temporárias, a possibilidade de restrições à livre circulação deixava a dinâmica econômica dos territórios inteiramente à mercê das prerrogativas militares das forças ocupantes, afastando potenciais investidores. As zonas industriais, assim, foram concebidas como espaços "à prova" destas restrições, embora isso nunca tenha sido de fato realidade, uma vez que, contraditoriamente, elas eram zonas voltadas para exportação - o que recolocava a dependência à livre circulação nas fronteiras.

Para o setor privado israelense, a ideia de zonas industriais, assim como os "processos de paz" de forma mais ampla, respondia à longa demanda por liberalização e internacionalização. O projeto de zonas industriais abria ao empresariado israelense a perspectiva de aprofundar a "terceirização" de parte considerável de sua produção para exportação, pagando salários mais baixos e beneficiando-se de isenções significativas. As zonas funcionariam como "outlets subsidiados para o capital israelense" (ADVANI, 2016, p.72): mesmo as companhias palestinas que operavam na ZIG, em geral, atuavam a partir de subcontratos com empresas localizadas em Israel (NAKHLEH, 2012). As zonas industriais, assim, representavam o "casamento entre as 'preocupações de segurança' de Israel e o neoliberalismo" (ADVANI, 2017, p.7), uma vez que permitiriam, a um só tempo, promover a internacionalização do capital israelense e evitar a entrada diária de massas de palestinos em território israelense (LAGERQUIST, 2003). Tratava-se, de fato, da mesma lógica que havia movido a iniciativa da Zona Industrial de Erez, agora com parceria e cooperação da elite política e econômica palestina e legitimada pelo enquadramento dos "processos de paz".

Além dos interesses privados palestino e israelense, a iniciativa de zonas industriais nos TPO, no contexto dos anos 1990, foi impulsionada centralmente pelo Banco Mundial, com participações importantes de outras agências e instituições, como a USAID e o Banco de Investimento Europeu (NAKHLEH, 2012). Explicitamente sintonizada com o espírito de Oslo - o discurso do desenvolvimento econômico dos TPO e dos “dividendos de paz", analisado no primeiro capítulo -, as zonas industriais foram vistas pela comunidade de assistência externa 
como potenciais polos privilegiados de atração de investimentos estrangeiros e locais (tanto palestinos quanto israelenses), que impulsionariam a produção para exportação. Nesse sentido, as brochuras promocionais da Zona Industrial de Gaza, analisada a seguir, classificavam-na como uma "janela para os mercados regionais e internacionais" (LAGERQUIST, 2003, p. 14). O resultado seria a geração de empregos palestinos, o crescimento econômico dos TPO e o fortalecimento do setor privado palestino, numa situação em que Israel manteria total controle sobre as fronteiras (NAKHLEH, 2012, p. 95). Previa-se, no início dos projetos, que entre 150 e 200 mil palestinos seriam empregados nas zonas industriais num período de dez anos. A própria escolha da localização do projeto piloto foi motivada por este objetivo, visando atenuar a crise de desemprego particularmente aguda na qual se encontrava a Faixa de Gaza (LAGERQUIST, 2003, p.8).

O projeto de zonas industriais visava, também, impulsionar os padrões de governança nos territórios, sintonizando a economia palestina às "melhores práticas" internacionais ${ }^{71} \mathrm{e}$ consolidando, assim, um ambiente regulatório sólido para investidores. Em sintonia com estas melhores práticas, como se disse, a gestão das zonas industriais seria entregue ao setor privado (LAGERQUIST, 2003, p.6). Além disso, em 1998, foi promulgada pela ANP a Lei n 10 para Cidades Industriais e Zonas Livres, na qual uma série de benefícios eram garantidos aos investidores $^{72}$. Entre os incentivos estavam isenções fiscais de sete a vinte anos, além da permissão de 100\% de propriedade estrangeira sobre os negócios (LAGERQUIST, 2003, p.12). A lei de 1998 também estabelecia uma agência reguladora para as zonas industriais nos territórios ocupados: a Palestinian Industrial Estates and Free Zones Authority (PIEFZA), concebida para atuar como uma instituição independente da ANP.

Embora as zonas industriais parecessem agradar tanto a empresários palestinos (fortemente ligados à ANP) quanto israelenses, as negociações entre a autoridade e Israel em torno da iniciativa de zonas industriais rapidamente emperraram. O governo israelense propôs um modelo semelhante ao que havia sido a experiência de Erez: uma zona industrial inteiramente controlada por Israel, onde o capital palestino também poderia investir. A ANP e os empresários palestinos rejeitaram a proposta, e foram adiante com a iniciativa sem a

\footnotetext{
${ }^{71} \mathrm{O}$ que se deu pelo aprendizado e emulação a partir de outras zonas industriais, voltadas para exportação, ao redor do mundo (Lagerquist, 2003, p. 6).

${ }^{72}$ Dana (2015, p.471) cita duas leis, estabelecidas pela PIEFZA e pela Palestinian Investment Promotion Agency, que garantiram incentivos a investidores das zonas industriais no contexto do Fayyadismo. Os benefícios garantidos envolvem isenções em impostos sobre renda, ativos fixos e exportações, livre movimentação de capital e remessas de lucros, garantias de investimento, acesso preferencial a certos mercados, etc.
} 
cooperação das autoridades oficiais israelenses. No setor privado, o projeto foi entregue à PADICO (por meio da subsidiária PIEDCO), cuja capacidade de agregar financiadores para o projeto piloto em Gaza foi posteriormente elogiada pelo Banco Mundial, em 2005 (BANCO MUNDIAL, 2005, p.11). De fato, mesmo sem participação oficial israelense, o projeto continuou sendo pesadamente financiado por instituições internacionais, como o Banco Mundial (BANCO MUNDIAL, 1997b; 2005).

Assim, apesar de as negociações políticas em torno das zonas industriais não terem rendido frutos, atores centrais continuaram a ver a iniciativa com bons olhos. A ausência de cooperação israelense significou, no entanto, que a garantia de livre circulação de bens e produtos de e para as zonas - fundamental para seu funcionamento regular - nunca foi obtida junto às autoridades da ocupação (BANCO MUNDIAL, 2005). As determinações previstas no Protocolo de Paris sobre relações econômicas, bem como nos outros acordos assinados no período, haviam garantido a Israel a prerrogativa de limitar o movimento das populações palestinas em nome de seus interesses de segurança. Lagerquist (2003, p.8) aponta, nesse sentido, como o arranjo imposto por Oslo, na prática, representava uma “institucionalização das restrições ao movimento" às quais a população palestina já estava sendo submetida, em maior ou menor grau, desde o fim dos anos 1980.

Em 2000, seis zonas industriais estavam em construção ${ }^{73}$, totalizando aproximadamente U\$250 milhões em investimentos: a Zona Industrial de Gaza (já em operação desde o ano anterior); a Zona Industrial de Jenin; a "Khadoury Information Technology Estate", em Tulkarem; o Parque Agroindustrial de Jericó, no Vale do Jordão; a Zona Industrial de Belém e a Zona Industrial de Tarqumiyah. No entanto, a única dessas zonas que chegou a entrar em operação, antes da eclosão da Segunda Intifada em setembro de 2000, foi a Zona Industrial de Gaza, cujo caso é tema das próximas seções.

\subsection{A Zona Industrial de Gaza: anos iniciais (1997-2000)}

A Zona Industrial de Gaza (ZIG) foi o experimento piloto do projeto de zonas industriais para os territórios palestinos. Concebida em 1997, a zona industrial foi inaugurada em 1999 próxima à passagem de Karni, no lado palestino da fronteira entre Israel e a Faixa Gaza, e tinha como principais objetivos a criação de empregos para a população palestina local e o crescimento econômico na Faixa de Gaza, cujas condições socioeconômicas na segunda metade

\footnotetext{
${ }^{73}$ No planejamento inicial da ANP, o projeto abrangeria um total de 9 zonas industriais, 3 na Faixa de Gaza e 6 na Cisjordânia (BANCO MUNDIAL, 2005, p.2).
} 
da década de 1990 eram desastrosas (ADVANI, 2016; BANCO MUNDIAL, 1997; LAGERQUIST, 2003, p. 14).

Figura 2 - Localização da Zona Industrial de Gaza.

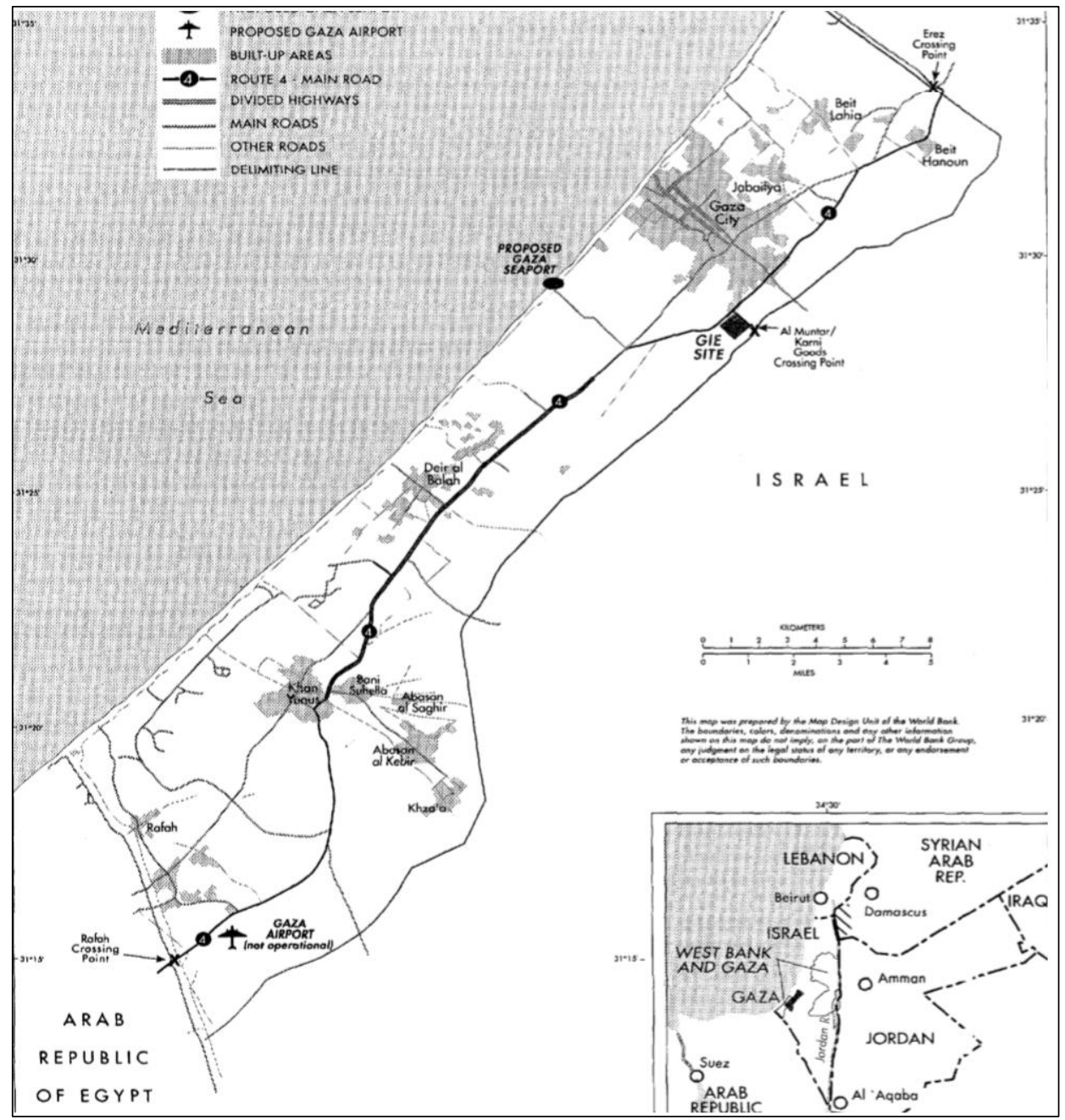

Fonte: BANCO MUNDIAL, 1997b, p.39.

A visão centrada na geração de empregos perpassa todo o documento de apreciação do Banco Mundial sobre o projeto da Zona Industrial de Gaza:

Os objetivos de desenvolvimento do projeto são aumentar o emprego direto e indireto em Gaza e contribuir para o PIB de Gaza ao criar condições propícias para o investimento industrial privado (BANCO MUNDIAL, 1997b, p.2).

Inicialmente, estimava-se que a ZIG viria a abrigar cerca de 250 empresas até 2006 (BANCO MUNDIAL, 1997b, p. 24). O objetivo do projeto era criar 6 mil empregos diretos até o início de 2001, quando metade da implementação do projeto estaria concluída. Até 2004, a 
meta era gerar 20 mil empregos diretos e 30 mil indiretos, agregando aproximadamente US $\$ 50$ milhões ao PIB de Gaza em 6 anos. Em termos de investimentos privados, estimava-se que a zona atrairia cerca de US\$ 200 milhões ao longo de todo o projeto, para além do dinheiro vindo dos financiadores (BANCO MUNDIAL, 1997b, p.16). Além disso, esperava-se que, ao impulsionar um melhor ambiente de negócios na região, o projeto acabaria também atraindo investimentos do setor privado fora da zona industrial - ou para as outras zonas em construção -, gerando assim um efeito multiplicador no desenvolvimento socioeconômico impulsionado nos territórios. Entre os "benefícios sociais" do projeto, o documento do Banco Mundial indica, de forma sucinta, a "[...] redução da dependência de assistência social (welfare) em Gaza; mudança de expectativas" (BANCO MUNDIAL, 1997b, pp. 2-3).

A iniciativa da ZIG foi financiada por um conjunto de atores. Quando o projeto foi lançado, o Banco Mundial comprometeu-se com US\$10,7 milhões ao longo de 6 anos. A International Finance Corporation (IFC) (pertencente ao Banco Mundial) e o BEI financiariam o projeto por meio da PIEDCO, com cerca de US\$25 milhões em auxílio financeiro à empresa. ${ }^{74}$ A companhia palestina, ainda, investiria US $\$ 13,9$ milhões no projeto. A USAID e o BEI contribuiriam com US\$6,3 e US\$5 milhões, respectivamente. Incluindo o valor do terreno, investido pela ANP, entre algumas outras contribuições, o projeto da Zona Industrial de Gaza tinha um custo total estimado em US\$84,5 milhões (BANCO MUNDIAL, 1997b, p. 1).

A participação do Banco Mundial no projeto da Zona Industrial de Gaza foi central. A iniciativa como um todo veio da autoridade palestina e da PADICO, mas estes rapidamente recorreram ao Banco em busca de assistência técnica e financeira. Quando da apreciação do projeto, em 1997, o Banco afirma que a iniciativa da ZIG seguiria adiante mesmo que seu auxílio fosse recusado - tão importante era o projeto aos olhos da ANP e da PIEDCO/PADICO (BANCO MUNDIAL, 1997b, p.6). Embora a participação do Banco Mundial nos custos do projeto seja relativamente pequena (cerca de 12\%) quando comparada às contribuições da ANP (cerca de 28\%), por exemplo, o Banco alega ter tido influência muito maior sobre o projeto do que sua fração no financiamento faz supor (BANCO MUNDIAL, 2005, p. 3). Sua influência em termos de concepção e assistência técnica a toda a iniciativa, de fato, é inegável e, como demonstra o caso das negociações em torno da estrutura para contenção de água de chuva, discutida adiante, o Banco se propôs a atuar como um facilitador do diálogo entre a ANP e as autoridades israelenses (BANCO MUNDIAL, 1997b, p. 6).

\footnotetext{
74 A IFC emprestaria US\$9 e o BEI emprestaria US\$16,1 milhões (além deste montante, o banco europeu contribuiu diretamente com mais US\$5 milhões).
} 
Figura 3 - Entrada da Zona Industrial de Gaza.

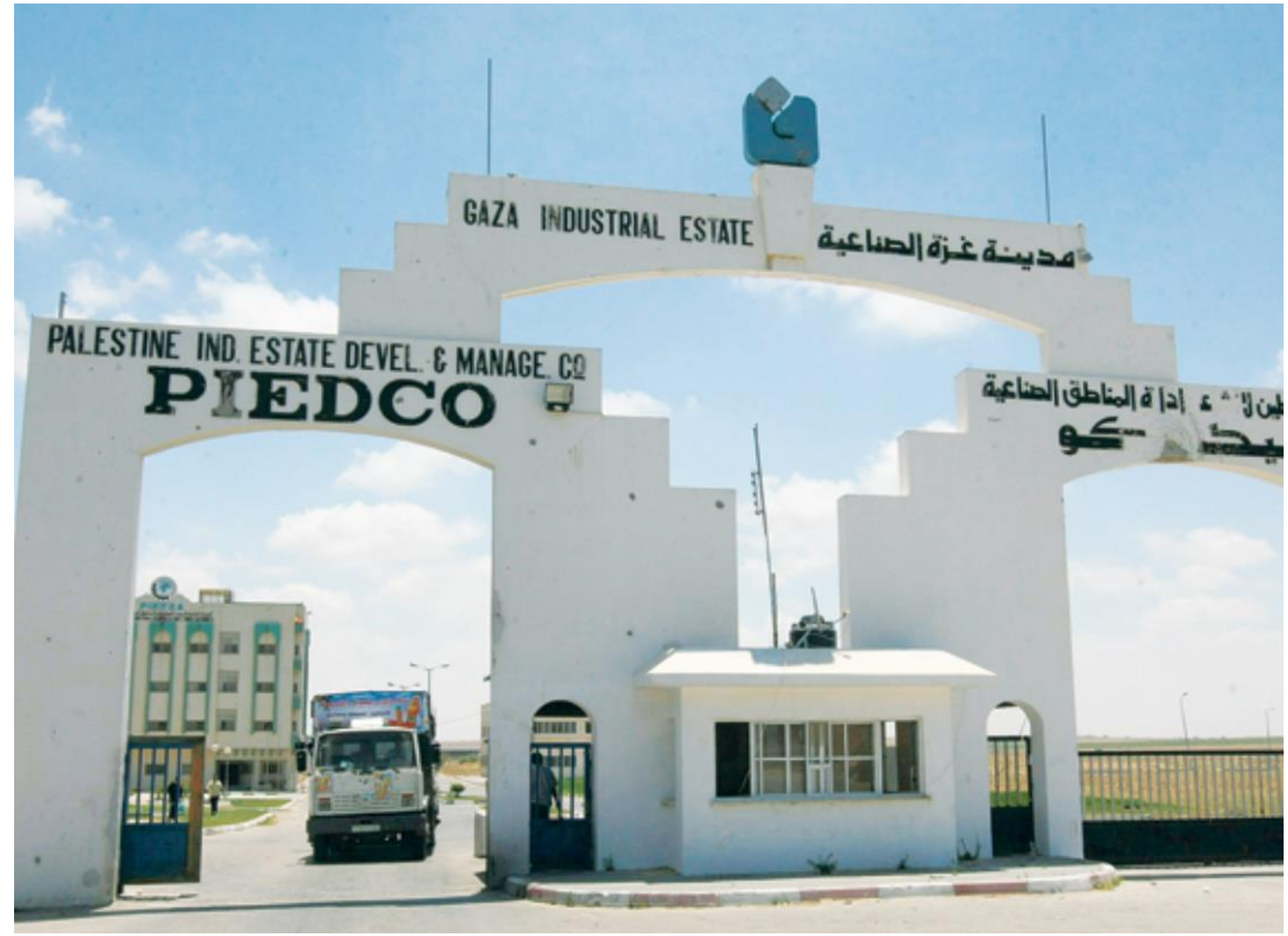

Fonte: Disponível em: < https://www.independent.co.uk/news/world/middle-east/pressure-on-israel-tolift-gaza-blockade-1999210.html >. Acesso em: 11/09/2020.

O projeto da Zona Industrial de Gaza oferecia, centralmente, uma resposta à insatisfação da comunidade internacional com as práticas da Autoridade Nacional Palestina. Na segunda metade dos anos 1990, foi se tornando explícito o fato de que a ANP não seguia os padrões de governança e accountability internacionais (BRYNEN, 2000; SAID, 2003). A corrupção e a patronagem eram sistemáticas nas estruturas da autoridade (BRYNEN, 1995), e em larga medida ocorriam com o conhecimento e acordo tácito dos principais doadores internacionais, como o Banco Mundial e a USAID (HADDAD, 2016; NAKHLEH, 2012). Apesar disso, as práticas erodiam a confiança dos investidores estrangeiros, degenerando o ambiente de negócios palestino. Numa pesquisa de 1995, por exemplo, indicava-se que a principal preocupação de investidores israelenses - no que tange a fazer negócios nos TPO - era o ambiente regulatório e "problemas conhecidos ao lidar com a ANP" (LAGERQUIST, 2003, p.11).

A busca por se distanciar das práticas conhecidas da ANP fica evidente nas palavras do gestor de relações públicas da PADICO, citado por Lagerquist (2003, p. 11): 
Se você é um investidor estrangeiro e você ouviu que a autoridade é um problema, você não precisa lidar com eles. Nós vamos processar suas aplicações como desenvolvedores e gestores do parque. Nós vamos submeter sua aplicação e obter a licença para fazer negócios. Se você não quiser ir a Gaza recrutar mão de obra, nós faremos isso para você. Nós teremos um centro de recrutamento. Se você quiser treinar seus funcionários, nós faremos isso para você...

O modelo baseado em parcerias público-privadas, que animava todo o projeto de zonas industriais, surgira assim em parte como alternativa às práticas corruptas e ineficientes da ANP, como fica evidente na fala do funcionário da PADICO. O modelo seria sustentado pela cooperação entre a autoridade - por meio da PIEFZA - e o setor privado palestino, tendo largo apoio financeiro da comunidade de doadores internacionais. As zonas industriais foram, assim, concebidas para funcionarem como "paraísos da boa governança" privatizados, que ofereceriam uma série de benefícios aos investidores palestinos, israelenses e estrangeiros (LAGERQUIST, 2003, p.11). Nota-se aqui - sem negar a corrupção e a patronagem da cúpula da ANP - a prática neoliberal de apresentar a gestão técnica privada como uma substituta legítima da ação pública e, mais que isso, uma fonte de transformação, de melhoria para as estruturas e práticas estatais.

O modelo de parceria com o setor privado buscava, também, garantir a competitividade da Zona Industrial de Gaza. Os valores cobrados pela PIEDCO para que as empresas operassem na $\mathrm{ZIG}^{75}$ eram consideravelmente (cerca de 50\%) menores do que o padrão internacional, embora fossem maiores do que nas zonas industriais da Jordânia, até então geridas pelo setor público $^{76}$. O risco de que a ZIG não alcançasse padrões mínimos de competitividade internacional era considerado "moderado" pelo Banco Mundial em 1997. Para minimiza-lo, a ANP havia sido aconselhada a assegurar legislações trabalhistas flexíveis (BANCO MUNDIAL, 1997b, p.13).

A licença para operar a ZIG, assim, foi dada à PIEDCO em 1997. Para o desenvolvimento do projeto, a ANP cedeu 48 hectares de terra à companhia, que obteve o terreno por 49 anos, numa relação de concessão em que a autoridade ofereceu "termos favoráveis" (BANCO MUNDIAL, 2005, p. 13). No "setor público" palestino, o enquadramento do projeto de zonas industriais nas "melhores práticas internacionais" significava a necessidade de simplificação da regulação e dos procedimentos necessários para investir nos TPO, além do

\footnotetext{
${ }^{75} \mathrm{US} \$ 26 / \mathrm{m}^{2}$ para galpões padronizados e US $\$ 6 / \mathrm{m}^{2}$ para lotes abertos (BANCO MUNDIAL, 1997b, p.8).

${ }^{76}$ O governo jordaniano, no entanto, já em 1997 buscava privatizar a gestão de suas zonas industriais (BANCO MUNDIAL, 1997b, p.8).
} 
fortalecimento institucional da ANP por meio da criação de uma agência reguladora específica. Assim, a PIEFZA foi, inicialmente, estabelecida sob os auspícios do Ministério da Industria Palestino. Após um período de transição de aproximadamente um ano, a agência se estabeleceu como uma entidade independente, contando com sua própria sede, corpo de funcionários e orçamentos (BANCO MUNDIAL, 1997b, p.10). Em suma, a meta da PIEFZA era, além de recolher impostos e ficar responsável pelas estruturas externas às zonas, funcionar como um "one-stop-shop" $" 77$ para investidores, tornando as zonas industriais mais simples e atrativas para investimentos (ADVANI, 2016).

Na divisão de tarefas estabelecida, a PIEFZA assumiria o papel de órgão regulatório das atividades da(s) zona(s), além de proprietário e gestor de toda a infraestrutura externa que seria desenvolvida para o projeto, como provisão de energia elétrica, água, esgoto, vias de acesso e estruturas para captação de água de chuva. A PIEDCO, por sua vez, seria a desenvolvedora privada da Zona Industrial de Gaza, sendo responsável por todo o desenvolvimento e gestão do local (construção de galpões, prédios administrativos, infraestruturas e provisão de serviços internos, publicidade, etc.). A iniciativa da Zona Industrial de Gaza buscava atrair três categorias de investidores: investidores palestinos; israelenses ou estrangeiros com "interesses políticos ou financeiros em investir na ZIG"; e investidores estrangeiros. Segundo projeções do Banco Mundial (1997b, p.7), somente com as duas primeiras categorias a ZIG já conseguiria atingir metade de suas metas de geração de empregos, tornando-se "economicamente viável". Assim, embora fosse evidentemente um objetivo central do projeto a atração de investimento estrangeiro, os planejamentos iniciais indicam que a ZIG foi concebida para ser, antes de mais nada, uma iniciativa econômica conjunta entre os setores privados palestino e israelense.

Chama a atenção, no relatório de apreciação do Banco Mundial para a ZIG, uma seção em que são expostos "aspectos possivelmente controversos" do projeto. A única controvérsia diz respeito aos pequenos industriais locais, já existentes e atuantes na Faixa de Gaza, que não poderiam transferir suas atividades para a nova zona industrial. Os pequenos e médios industriais palestinos não estavam entre os alvos do projeto da ZIG, e segundo o Banco Mundial, se estivessem, "muitos destes empreendedores transfeririam empregos para a ZIG" (BANCO MUNDIAL, 1997b, p.14), isto é, não estariam criando novos empregos ao se estabelecerem na nova zona industrial. Em compensação à limitação imposta aos investidores

\footnotetext{
77 Isto é, centralizar o oferecimento de serviços a clientes interessados em investir nas iniciativas de zonas industriais nos TPO.
} 
locais, o Ministério da Indústria prometia avançar programas industriais municipais em Gaza, direcionados a estes empresários.

No mesmo relatório, o Banco expõe algumas alternativas aventadas ao projeto, quando de sua apreciação, e os motivos pelos quais foram rejeitadas. Uma das alternativas era, justamente, "apoiar zonas industriais municipais ou locais ao invés de zonas de fronteira". A ideia havia sido rejeitada pois o "desenho do projeto estava menos avançado" e porque era improvável que ele gerasse o mesmo nível de empregos (BANCO MUNDIAL, 1997b, p. 5). A necessidade de produção para exportação advinha, sobretudo, do pequeno mercado representado pela população da Faixa de Gaza (BANCO MUNDIAL, 1997b, p.7).

Contudo, essa priorização absoluta pela geração de empregos novos não parece estar presente em outra seção do relatório, na qual são citados os cerca de 30 mil trabalhadores palestinos com elevada formação técnica, que previamente trabalhavam em Israel e, agora, seriam absorvidos pela criação de empregos na ZIG (BANCO MUNDIAL, 1997b, p.5). De fato, esta transferência de trabalho palestino de empresas localizadas em Israel para dentro da nova zona industrial - cuja concepção se pode traçar à "solução de terceirização" de Ezra Sadan e à Zona de Erez - parece ser valorizada novamente pelo Banco Mundial. Evidentemente, tratava-se de uma solução que favorecia o capital israelense, que podia terceirizar sua produção para os territórios palestinos, pagar salários mais baixos e evitar a entrada de palestinos em território israelense.

A segurança da zona, responsabilidade da PIEDCO, foi terceirizada para a empresa israelense NETACS, que "possui conexões muito próximas com as FDI" (ADVANI, 2016, p.72). Era bastante plausível supor que as próximas zonas, a serem inauguradas nos anos seguintes, também seguiriam caminho semelhante. Além disso, identidades magnéticas eventualmente foram adotadas para controlar o fluxo de trabalhadores, constituindo, progressivamente, o que Lagerquist (2003, pp.16-17) denomina uma "securitização" da Zona Industrial de Gaza.

Chama a atenção, ainda, o fato de o relatório de apreciação do Banco Mundial não contar com uma avaliação social. Após longas seções destinadas à "avaliação econômica", "financeira", "técnica" e "institucional" do projeto da ZIG, o documento se furta de dedicar uma seção à “avaliação social”, afirmando que uma análise deste tipo não se aplicaria ao projeto da zona. 


\subsection{Um projeto de risco}

O projeto da Zona Industrial de Gaza foi, desde o princípio, avaliado como altamente arriscado pelo Banco Mundial e demais financiadores. Seu risco foi considerado "substancial", derivado do "risco político geral" associado aos processos de Oslo. Na visão do Banco (1997b, p.13), contudo, era “improvável” que os “processos de paz” desmoronassem completamente ${ }^{78}$, embora "atrasos e retrocessos" pontuais fossem esperados desde o início. Acima de tudo, preocupava a possibilidade de que os fluxos de fronteira não fossem se manter estáveis ao longo do tempo (BANCO MUNDIAL, 1997b, p. 13). No relatório de finalização do projeto, divulgado pelo Banco Mundial em 2005, afirma-se que há evidências de que o governo israelense havia concordado verbalmente em facilitar o funcionamento da zona e a livre circulação de produtos e pessoas. Israel, no entanto, nunca aceitou assinar qualquer protocolo que, por exemplo, elevasse as zonas industriais a um status superior no que tange à livre circulação (BANCO MUNDIAL, 2005, p.5; DANA, 2015, p.470). Significativamente, o Banco reconhece, após o fim do projeto, que mesmo que garantias escritas tivessem sido obtidas, é difícil supor que Israel as teria respeitado. A iniciativa da ZIG, assim, foi levada adiante apesar de altos riscos: qualquer alteração nas condições políticas imediatas poderia acarretar o fechamento total das fronteiras pelas forças israelenses e, no limite, a inviabilização do funcionamento de uma zona industrial que se voltava antes de tudo à exportação (BANCO MUNDIAL, 2005).

De fato, há no relatório do Banco uma forte ênfase no risco do fechamento das fronteiras por Israel. Poucas menções são feitas a outros desenvolvimentos políticos que, desde 1993, haviam explicitado a real natureza das intenções israelenses com os "processos de paz". Como discutido anteriormente, a expansão contínua dos assentamentos, declarações sobre Jerusalém Oriental e o Vale do Jordão, a ascensão do Likud ao poder: tudo já indicava, no final de 1997, que qualquer que fosse o objetivo de Israel com os acordos, ele não envolvia mais que um autogoverno extremamente limitado aos palestinos, em pequenos bantustões urbanos nos TPO. Já estava evidente, sobretudo, que as principais forças em Israel não abririam mão de qualquer soberania, e que a criação da ANP havia feito pouco além de terceirizar serviços previamente geridos pela Administração Civil da ocupação (HEVER, 2010; SAID, 2003, pp.177-192). O relatório do Banco Mundial não faz, contudo, praticamente nenhuma menção aos desgastes mais gerais de Oslo enquanto um processo que levaria à "paz" entre os dois povos. O foco,

\footnotetext{
${ }^{78}$ Vale ressaltar que o primeiro-ministro israelense, nesse momento, era Benjamin Netanyahu, eleito em 1996 com uma agenda radicalmente contrária aos "processos de paz" com os palestinos.
} 
como se disse, é unicamente no risco da interrupção ao livre movimento de produtos e pessoas ligados à ZIG - interrupção que já era praticada por Israel com frequência desde a Primeira Intifada e que, ao menos desde 1995, era uma possibilidade bastante iminente.

Diante de tal possibilidade, o Banco aponta, como "medida de minimização de risco", o "envolvimento significativo de investidores israelenses e internacionais" (BANCO MUNDIAL, 1997b, p.12). Nota-se, aqui, a compreensão de que uma interação econômica intensa entre investidores palestinos e israelenses, na Zona Industrial de Gaza, contribuiria para os “processos de paz", e seria útil para inibir Israel de fechar as fronteiras, inviabilizando, assim, o funcionamento da ZIG. Novamente, mostra-se atuante a lógica liberal de buscar, por meio da interação e interdependência econômicas, a solução para questões políticas - e, nesse caso, coloniais.

Os altos níveis de "incerteza política" são apontados como um dos principais fatores que dificultavam o desenvolvimento do setor privado nos TPO - desafio importante para o sucesso da ZIG e de outras iniciativas da assistência externa. Como principal "estratégia da ANP" para combater este problema, o Banco indicou justamente a continuidade dos "processos de paz". Contudo, foi também sugerida a realização, em paralelo, de uma abordagem "caso a caso", em negociações bilaterais com Israel para tratar de questões específicas (BANCO MUNDIAL, 1997b, p.4). O relatório do Banco demonstra confiança nesta abordagem, e considera a iniciativa da ZIG como seu "exemplo mais avançado":

Discussões bilaterais com aconselhamento técnico e apoio da USAID e do Banco Mundial estão bastante avançadas, particularmente focando em estabelecer arranjos satisfatórios voltados a garantir que o fluxo de bens e trabalho será afetado pelos fechamentos da fronteira somente em circunstâncias excepcionais (BANCO MUNDIAL, 1997b, p.4, grifo nosso).

Assim, mesmo na ausência de um comprometimento geral de Israel para a iniciativa das zonas industriais, ou mesmo de uma garantia que se estendesse somente à ZIG, os financiadores do projeto aceitaram ir adiante, e passaram a advogar por uma abordagem distinta, baseada em negociações pontuais entre, de um lado, a ANP e/ou a PADICO (apoiadas por doadores) e, de outro, as autoridades israelenses. Vale notar, também, que mesmo ao tratar de negociações tão específicas, o Banco ainda resguarda às forças israelenses a prerrogativa de barrar produtos e pessoas da ZIG nas fronteiras "em circunstâncias excepcionais".

O principal exemplo dessa estratégia "caso-a-caso" esteve relacionado à construção da estrutura de captação de água de chuva, necessária para evitar a inundação de áreas da zona industrial e de seus arredores em casos de tempestades. A construção da estrutura foi 
parcialmente afetada por operações militares israelenses durante a repressão à Segunda Intifada. A localização da zona na fronteira, além disso, tornava o local perigoso, motivo pelo qual a construção foi paralisada por longos períodos. A finalização da construção não foi permitida pelas autoridades israelenses, até que um acordo foi obtido através da mediação do Banco Mundial, num exercício de sua abordagem ad hoc. Este foi, também, o motivo pelo qual o encerramento de todo o projeto da zona precisou ser adiado em um ano (BANCO MUNDIAL, 2005, p.13).

No entanto, a abordagem de negociações caso a caso com as autoridades israelenses com frequência não foi suficiente para contornar os obstáculos impostos pelas políticas de Israel para as fronteiras com os territórios ocupados. As vias de acesso à ZIG, e desta para a passagem

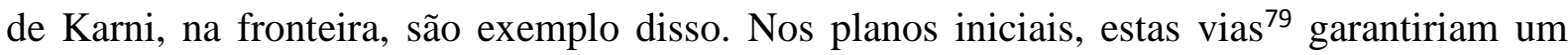
tráfego separado dos produtos da zona para a fronteira. Contudo, as autoridades israelenses "insistiram no uso conjunto da estrada para todo o tráfego comercial destinado a Israel" (BANCO MUNDIAL, 2005, p.9). A determinação israelense não pôde ser contornada pela PIEDCO, PIEFZA ou pelo Banco Mundial, e acabou gerando "atrasos significativos" (BANCO MUNDIAL, 2005, p.9) no acesso dos produtos da ZIG à fronteira com Israel. Assim, a Zona Industrial de Gaza foi privada do que era um de seus principais "mecanismos de marketing": acesso privilegiado à fronteira e aos serviços de alfândega. As mesmas vias de acesso, ainda, foram danificadas por operações militares israelenses durante a repressão à Intifada, e precisaram ser reparadas (BANCO MUNDIAL, 2005, p.9).

Sendo ou não produtiva para o lado palestino, a abordagem caso a caso acabou prevalecendo desde os anos iniciais da ZIG. Diante da ausência de garantias formais, "as indústrias operantes [na zona] e a PIEDCO encontraram formas para lidar com as limitações" (BANCO MUNDIAL, 2005, p.12), o que significou, concretamente, a obtenção de acordos informais e paralelos entre empresários palestinos e empresários e autoridades israelenses (LAGERQUIST, 2003). Com a intensificação das restrições impostas por Israel a partir de setembro de 2000, no entanto, mesmo estes "mecanismos ad hoc" deixaram de ser suficientes para garantir a sustentabilidade da atividade econômica na ZIG (BANCO MUNDIAL, 2005, p. $12)$.

Uma outra preocupação, central para o Banco Mundial desde a concepção do projeto, era a possibilidade de que o governo de Israel viesse a inibir investidores israelenses que

\footnotetext{
79 A construção parcial de vias de acesso, e a realização de melhorias e adaptações nas já existentes, eram componentes da infraestrutura externa a ser estabelecida no escopo do projeto da ZIG.
} 
buscassem atuar na Zona Industrial de Gaza. Segundo o relatório de apreciação, um comitê interministerial teria sido criado para garantir que isso não ocorresse. A zona em Gaza, assim, de fato era vista como uma iniciativa concreta de cooperação entre o setor privado do poder ocupante e aquele do povo ocupado. Como apontam ao Banco Mundial os empresários palestinos, atuantes na ZIG em 2005, o "problema é com as autoridades israelenses, e não com o empresariado israelense" (BANCO MUNDIAL, 2005, p. 15). Assim como ocorreu com os fechamentos das fronteiras, no entanto, neste caso também as preocupações do Banco, da ANP e da PIEDCO se tornariam realidade: a partir do fim de 2000, o governo israelense passaria a retirar suas empresas da ZIG (NAKHLEH, 2012).

O risco do projeto da Zona Industrial de Gaza se refletiu, como visto, na preocupação do Banco Mundial com a operacionalização de parte das estruturas externas necessárias ao funcionamento da iniciativa. Parte fundamental do projeto da ZIG estava relacionado à provisão de infraestruturas como oferecimento de água, captação de esgoto e de água de chuva, construção de vias de acesso e conexão com a fronteira, etc., os quais precisariam ser construídos para que a zona pudesse operar regularmente. A oferta de energia elétrica era, também, um componente central das infraestruturas externas. Na apreciação feita pelo Banco Mundial, enfatiza-se que o sistema de oferecimento de energia a ser estabelecido para o projeto asseguraria a "redundância" na oferta de energia, garantindo que o funcionamento da zona não fosse afetado pelos constantes cortes na provisão de eletricidade impostos por Israel à Faixa de Gaza. Este ponto é considerado particularmente sensível para o Banco, que ressalta a importância, para a ZIG, de conseguir continuar funcionando apesar da imprevisibilidade na provisão de energia (BANCO MUNDIAL, 1997b, p.9; 2005).

É significativo que o Banco Mundial estivesse defendendo a continuidade de um projeto cujas chances de sucesso dependiam de acordos tão improváveis com os israelenses. O projeto da ZIG se filiava, explicitamente, aos "processos de paz" mais amplos, e sua própria sustentabilidade dependia de boas relações com as autoridades israelenses (BANCO MUNDIAL, 1997b, p.5). No entanto, como já discutido, se consolidava na sociedade israelense, nos anos subsequentes a 1993, um consenso em torno do que significavam os "processos de paz" para Israel. Essa versão israelense minimalista dos acordos de Oslo foi implementada tanto pelos governos trabalhistas quanto pelos governos do Likud. Nas eleições israelenses de 1996, as posições de ambos os partidos nas questões relacionadas aos acordos com os palestinos eram bastante semelhantes. Segundo as propostas do Partido Trabalhista, os 144 assentamentos 
israelenses deveriam ser mantidos, e a maioria deles anexados por Israel ${ }^{80}$. Além disso, Jerusalém continuaria sobre completo controle israelense, como a capital una e indivisível do país. Ambas as posições eram compartilhadas pelo Likud (PAPPE, 2006a, pp.272-273).

Ambos os lados também pareciam se reconciliar com a ideia de algum tipo de Estado palestino nos territórios que sobrassem, um Estado com muito pouca soberania ou independência de fato (PAPPE, 2006a, p.273).

As perspectivas dos "processos de paz", portanto, estavam longe de apontar para a real independência palestina e, como dito, desde 1995 as limitações à livre circulação dos palestinos haviam se acentuado. Assim, a negativa israelense em oferecer garantias ao projeto de zonas industriais em geral - e à ZIG em particular - apenas reforçava, num contexto como esse, os indícios de que o controle israelense sobre todas as fronteiras dos TPO representaria, em pouco tempo, um sério problema à iniciativa. O Banco Mundial (2005, p. 12) afirma, contudo, que

[...] apesar dos riscos envolvidos em prosseguir com o projeto, não havia melhores alternativas para promover o desenvolvimento voltado para exportação da economia palestina.

\subsection{O declínio da Zona Industrial de Gaza (2000-2007)}

Enquanto a economia israelense vivia uma recuperação significativa, marcada por altos níveis de crescimento, nos anos que se seguiram à assinatura da Declaração de Princípios (1993) o processo de deterioração da economia palestina nos TPO se aprofundou. Na Cisjordânia e em Gaza, as taxas de desemprego e pobreza cresceram entre 1994 e 2000, e o PIB sofreu uma redução de 3,8\% (DANA, 2015, p.463). Nos anos de 1996-1997, as condições econômicas nos TPO haviam atingido proporções críticas, com picos de desemprego (atingindo 37\% em 2000), reduções dramáticas no comércio e aumento geral nos níveis de pobreza (NAQIB, 2003, pp.501;507). Dentre os principais motivos para este declínio econômico geral estava a política de fechamento de fronteiras imposta por Israel, que se intensificou na segunda metade da década de 1990. O governo israelense mobilizava justificativas de segurança, e acusava a autoridade palestina de não conseguir conter grupos como o Hamas e a Jihad Islâmica, cujos ataques contra alvos civis e militares israelenses se multiplicaram em 1995. O Fatah, por sua vez, criticava os atos do Hamas, mas colocava a responsabilidade pela situação das populações palestinas nas duras políticas do governo israelense (NAQIB, 2003, p.501; PAPPE, 2006a).

\footnotetext{
${ }^{80}$ Em 1997, a política de assentamentos continuava: na Faixa de Gaza, $40 \%$ do território era diretamente controlado por Israel, enquanto na Cisjordânia esse número era de 74\% (NAQIB, 2003, p.508).
} 
A deterioração dos "processos de paz", já evidente quando o projeto da ZIG foi concebido em 1997, intensificou-se em 2000. A frustração palestina com os resultados de Oslo era generalizada. De 1993 a janeiro de 2001, o número de assentamentos israelenses nos territórios ocupados havia dobrado (KHALIDI, 2006, p.158; NAQIB, 2003, p.510), as restrições ao livre movimento haviam se aprofundado e nenhum avanço havia sido feito em direção a nenhuma das “questões de status permanente". As forças da ocupação, ainda, haviam continuado as práticas sistemáticas de demolições de construções palestinas em áreas $\mathrm{C}$, além de constantes confiscos de terras e outros recursos, como poços d'água (NAQIB, 2003, p.501). Em julho, as negociações de Camp David II falharam (HADDAD, 2016) e, em 28 de setembro, eclodiu a Segunda Intifada.

Contra o levante palestino, Israel mobilizou suas forças imensamente superiores e iniciou uma forte política de repressão, à qual militantes e organizações palestinas, como o Hamas, responderam com mais ataques contra soldados e colonos israelenses. Uma onda de ataques à bomba se iniciou nas cidades israelenses, levando à morte de centenas de civis de Israel. Em março de 2002, a escalada de violência atingiu o auge quando o exército israelense invadiu as principais cidades palestinas, de onde havia saído quase dez anos antes. Os aparatos policiais da Autoridade Nacional Palestina foram completamente destruídos, vários ministérios invadidos e saqueados e milhares de oficiais e/ou militantes palestinos foram presos (NAQIB, 2003, p.501).

Rapidamente, as empresas israelenses começaram a deixar a ZIG - a única das zonas industriais que já estava em operação ${ }^{81}$ (além da zona israelense de Erez) -, o que representou um golpe significativo a todo o projeto. As forças de segurança israelenses passaram a suspender as permissões para que os palestinos fossem ao trabalho, afetando progressivamente as atividades econômicas no interior do parque. Nesse contexto, o programa de zonas industriais nas fronteiras entre Israel e os TPO foi indefinidamente suspenso, e as construções em andamento foram paralisadas. A exceção foi a Zona Industrial de Gaza, cujo funcionamento e financiamento, embora reduzidos, continuaram apesar da Intifada e da repressão israelense (LAGERQUIST, 2003, p.17; BANCO MUNDIAL, 2005). Contudo, embora ainda operante, a partir de 2000 a zona passaria por um progressivo processo de declínio.

A ZIG chegou a abrigar, em seu auge, 28 empresas (em setembro de 2000), empregando cerca de 1200 trabalhadores palestinos (BANCO MUNDIAL, 2005, p.20) - sobretudo em

\footnotetext{
${ }^{81}$ A abertura de uma segunda zona industrial, em Jenin, no norte da Cisjordânia, estava programada para abril de 2001 (LAGERQUIST, 2003, p. 17).
} 
funções de pouco valor agregado, no setor têxtil. O número de empregos gerados foi significativamente menor do que aquele previsto para a primeira metade do projeto: a zona industrial gerou, até o início de 2001, apenas cerca de 20\% dos 6 mil empregos diretos esperados para o período. Quando do encerramento do programa de financiamento, em 2005, os números haviam piorado: dos 20 mil empregos diretos inicialmente estimados, menos de $7 \%$ foram de fato criados, e dos 30 mil empregos indiretos, somente cerca de 1600 foram gerados ao longo de todo o período de funcionamento da zona (ADVANI, 2016, p.70).

O salário anual de um trabalhador não qualificado na Zona Industrial de Gaza era, em média, de US\$2.383,23, ao passo que o salário de um trabalhador qualificado era de US\$4.089,49. Embora, como argumenta Advani (2016, p.68), esses salários parecessem adequados em uma economia onde o PIB per capita era de US\$1.455,9, o salário médio de um palestino trabalhando em Israel era consideravelmente maior (em 2004, por exemplo, este valor era de aproximadamente US\$5.370). Aproximadamente metade das empresas que se estabeleceram na ZIG era de propriedade palestina, enquanto a outra metade pertencia a capital israelense. Praticamente todas as empresas palestinas operando, contudo, tinham suas atividades subcontratadas por empresas israelenses (NAKHLEH, 2012, p. 96). Assim, é difícil afirmar que a iniciativa da ZIG constituiu, de fato, uma alternativa ao emprego palestino em Israel, uma vez que este continuava sendo significativamente mais vantajoso em termos salariais e que as operações na zona envolviam, em grande medida, a terceirização para firmas israelenses. Mais do que isso, a experiência na zona de Gaza não parece ter contribuído, em geral, para superar a dependência econômica dos TPO em relação à economia e ao capital israelense (ADVANI, 2016, pp.69-70; BANCO MUNDIAL, 2005). Quando este deixou de investir em Gaza e, se poderia dizer, algum tipo de desenvolvimento autônomo se tornou possível, as forças militares estavam lá para lembrar aos palestinos, rapidamente, que sua submissão a Israel não é apenas econômica.

O projeto da zona industrial também falhou em atingir seus objetivos iniciais em termos de contribuição ao PIB palestino. Inicialmente, esperava-se que a iniciativa contribuiria em cerca de US\$14,4 milhões para a economia da Faixa de Gaza até a metade do projeto, e US\$38,4 milhões até 2004. De acordo com a PIEFZA, no entanto, até o fim de 2000 o valor agregado pela ZIG havia sido de aproximadamente US\$4,3 milhões (cerca de 30\% da meta) e de aproximadamente US\$4,4 milhões até junho de 2005 (cerca de 11,5\% do objetivo final). No que tange à atração de investimentos, também, o objetivo inicial de US\$ 180 milhões não esteve nem perto de ser atingido: quando do encerramento do projeto, o total de investimentos 
planejados na ZIG pelos inquilinos era de US\$22,5 milhões (11\% da meta), valor que, segundo a PIEFZA, deve representar mais que o dobro dos montantes que realmente foram investidos na zona. Como um todo, portanto, a ZIG falhou em atingir seus objetivos declarados. Englobando as metas de geração de emprego, atração de investimentos, valor agregado ao PIB e desenvolvimento da área local, o projeto atingiu, em média, apenas $12 \%$ dos objetivos inicialmente estimados, sendo que $63 \%$ do total de gastos planejados foi, efetivamente, dispendido ao longo de todo o projeto (BANCO MUNDIAL, 2005, p.7).

A implementação do projeto da Zona Industrial de Gaza foi, como visto, atravessada desde o início pela realidade da ocupação e pelo enquadramento do autogoverno limitado dos “processos de paz”. Para além da negação israelense em oferecer garantias de livre movimento à ZIG, uma série de outros obstáculos foram enfrentados. A construção de componentes importantes do projeto - como a estrutura de captação de água de chuva - sofreu atrasos significativos devido a operações das forças israelenses, e mesmo a avaliação regular do projeto pelo Banco Mundial não pôde ser plenamente realizada: as missões do Banco frequentemente tiveram acesso negado à Faixa de Gaza (por vezes, como aponta o relatório de 2005, quando a missão já se encontrava na Cisjordânia) (BANCO MUNDIAL, 2005, p.12).

No que tange à provisão de energia elétrica, a "redundância" na oferta para a ZIG, apontada mais de uma vez como importante pelo Banco Mundial, não foi obtida: o sistema de abastecimento da zona industrial manteve-se parcialmente acoplado à rede elétrica da Municipalidade de Gaza, e assim sujeito aos "problemas de oferta" de energia, termo generoso do Banco Mundial para a política da ocupação de cortes prolongados no abastecimento de energia elétrica à Faixa de Gaza (BANCO MUNDIAL, 2005, p.9).

Embora tenha continuado em funcionamento após 2000, as operações da Zona Industrial de Gaza tornaram-se cada vez mais difíceis. Muitos empregadores passaram a flexibilizar os horários de funcionamento e os turnos de seus funcionários, diminuindo significativamente a produção e a renda gerada (ADVANI, 2016, pp. 69-70; BANCO MUNDIAL, 2005, p.7). Em dezembro de 2000, o número de empresas operando na ZIG havia se reduzido a 16 (uma redução de $40 \%$ em dois meses). Apesar de uma ligeira recuperação nos meses seguintes (seguida de quedas nos meses subsequentes), este número nunca voltou ao patamar de setembro de 2000. O número de trabalhadores da zona industrial, igualmente, caiu de forma dramática no fim de 2000: de quase 1200 empregados, em setembro, para 506 em dezembro. De aí em diante, a ZIG empregaria uma média de 800 trabalhadores palestinos (BANCO MUNDIAL, 2005, p.20). 
$\mathrm{O}$ aprofundamento das restrições israelenses fez com que se intensificasse, nesse período, a dinâmica de normalização já citada acima: para contornar as limitações de circulação sobre seus produtos - isto é, para conseguir exportá-los - os empresários palestinos com negócios na ZIG recorreram a "parceiros" israelenses. Tratavam-se de indivíduos e empresas com acesso privilegiado ao governo de Israel e/ou às burocracias das autoridades de fronteira e das Forças de Defesa Israelenses. Estes empresários e oficiais israelenses passaram a funcionar como mediadores entre os produtores palestinos e Israel. Os acordos negociados e fechados por esses indivíduos e suas empresas envolveram algumas das maiores companhias palestinas, como a PADICO e a PALTEL, garantindo ao grande empresariado palestino o escoamento de sua produção. Vale apontar, ainda, que em parte dos arranjos realizados nesse contexto os produtos palestinos acabavam sendo escoados como produtos israelenses ${ }^{82}$ (LAGERQUIST, 2003, p.14-15; NAKHLEH, 2012; HADDAD, 2016). A negociação direta entre elementos do setor privado palestino e as forças israelenses é explicitamente apontada pela PIEDCO, que afirmou ao Banco Mundial ter tomado uma série de iniciativas independentes da PIEFZA para tentar negociar termos de livre acesso com as forças israelenses (BANCO MUNDIAL, 2005, p.15).

Em uma conversa com a missão de avaliação do Banco Mundial, em 2005, os empresários ainda atuantes na ZIG afirmaram que "a maior parte dos 'sobreviventes' atuais dependem de apoio de parceiros israelenses para transportar seus produtos e obter matérias primas" (BANCO MUNDIAL, 2005, p.15). Também a PIEFZA, em um balanço feito pela companhia sobre a experiência da ZIG, afirma que desde o início da iniciativa era amplamente compreendido que a "cooperação com o lado israelense era essencial para se ter um projeto bem-sucedido" (BANCO MUNDIAL, 2005, p.14). A ausência de cooperação com as forças de segurança israelenses, assim, foi parcialmente (mas nunca completamente) contornada pelo empresariado palestino por meio do estreitamento da cooperação com setores do empresariado e do setor público de Israel.

As restrições e operações militares israelenses contra da Faixa de Gaza fizeram com que todo o escopo do projeto de construção da ZIG precisasse ser diminuído. Após o fim do projeto, dos US $\$ 84,5$ milhões inicialmente estimados, US $\$ 53,5$ milhões foram de fato dispendidos no estabelecimento da ZIG (como dito acima, apenas 63\% do total). A PIEDCO, que inicialmente havia planejado a construção da zona em três fases, decidiu cancelar a implementação da

\footnotetext{
${ }^{82}$ Como aponta Tartir (2012, p.6), um dos grandes benefícios para as empresas operantes nas zonas industriais propostas pela ANP é a possibilidade de utilizar o rótulo "Made in Palestine".
} 
terceira fase, e reduziu a extensão da segunda. Da mesma forma, a PIEFZA precisou reduzir o desenvolvimento externo planejado para a zona (BANCO MUNDIAL, 2005, p. 8; p.11). Chama a atenção o fato de que, até metade do programa (fim de 2000 - início de 2001), apenas 32\% da área da ZIG já havia sido plenamente "desenvolvida" pela PIEDCO (as projeções iniciais estimavam $75 \%$ de desenvolvimento do local, até a metade do projeto). Tendo em vista que o "desenvolvimento local" foi um dos poucos objetivos que o projeto atingiu completamente, assume-se que os outros $68 \%$ da zona industrial, portanto, foram desenvolvidos depois de 2000, isto é, após o início da Intifada, das repressões israelenses e da deterioração absoluta das perspectivas de sucesso da ZIG (BANCO MUNDIAL, 2005, p.18).

Após cinco anos de Intifada e apesar da dura repressão vinda do lado israelense, aproximadamente 20 empresas ainda operavam na Zona Industrial de Gaza em 2005. Findado o projeto de assistência externa, a PIEDCO planejava continuar a operar a zona independentemente, e afirmava ter os recursos para isso (BANCO MUNDIAL, 2005, p.15). No início de 2006, no entanto, eleições gerais deram ampla maioria ao partido islâmico Hamas no Conselho Legislativo Palestino. O resultado das eleições não foi reconhecido por Israel, Estados Unidos e membros centrais da comunidade internacional, que consideram o Hamas uma organização terrorista. Como resposta, os principais doadores internacionais estabeleceram imediatamente um bloqueio ao novo governo, cortando os fluxos financeiros que, até então, sustentavam os orçamentos da autoridade. O Fatah, tampouco, reconheceu a vitória do Hamas, instaurando um impasse à continuidade da ANP.

Como resposta à vitória do Hamas, Israel intensificou os níveis de repressão à Faixa de Gaza. Os assassinatos de militantes palestinos escalonaram em meados de 2006, e vários ataques aéreos e de artilharia contra o território palestino foram realizados (KHALIDI, 2007). Aproximadamente um terço dos membros do Conselho Legislativo Palestino foi preso - a maioria do Hamas -, o que causou a suspensão do Conselho (MUSTAFA, 2010). Embora relativamente contido no início, o Hamas rapidamente respondeu à dinâmica de violência, sequestrando soldados israelenses e lançando mísseis contra território israelense. Novas incursões israelenses em Gaza e a escalada geral da violência fizeram com que o Hezbollah também se envolvesse no conflito (KHALIDI, 2007).

Negociações foram tentadas entre o Fatah e o Hamas, como o acordo de Meca, realizado em fevereiro de 2007 sob mediação jordaniana, que estabelecia um governo de coalizão englobando os dois partidos. Os acordos não se mantiveram, e em julho de 2007 a Faixa de Gaza foi palco de uma sangrenta conflagração entre membros do Hamas e do Fatah, com 
batalhas violentas tomando as ruas de Gaza e de Rafah (KHALIDI, 2007, pp. x-xii). O Hamas acabaria por garantir o controle sobre a Faixa de Gaza em 2007 e, desde então, Israel passou a impor um cerco completo - terrestre, aéreo e marítimo - ao território. A comunidade internacional, como dito, tampouco reconhecera o governo do Hamas, e desde sua eleição mantém o boicote total à ANP em Gaza. Diante do completo cerco israelense e do bloqueio financeiro internacional, assim, as operações da Zona Industrial de Gaza foram completamente paralisadas em 2007 (DANA, 2015).

\subsection{Balanço e perspectivas: a insistência no desenvolvimento neoliberal}

Ao final do financiamento do projeto, em 2005, a postura do Banco Mundial foi ressaltar que os riscos da Zona Industrial de Gaza eram conhecidos desde o início, e que a iniciativa só prosperaria se os "processos de paz" tivessem gerado resultados concretos, sobretudo no que diz respeito aos controles de fronteiras. Ao invés de apontar qualquer inadequação no modelo de desenvolvimento aplicado - um modelo que não desafia a dependência palestina das forças ocupantes (por exemplo através da falta de controle sobre o movimento) -, a avaliação do Banco afirma que os "objetivos de desenvolvimento" do projeto, sob os quais ele foi considerado "insatisfatório", deveriam ter sido outros. Ao invés de enfatizar a criação de empregos ou a contribuição ao PIB, o planejamento do projeto da ZIG deveria, segundo o Banco Mundial, ter diminuído as estimativas e previsto que os principais benefícios da iniciativa viriam sobretudo do desenvolvimento institucional, isto é, do fortalecimento dos órgãos e agências da ANP e da "formação de uma parceria público-privada de sucesso" entre a autoridade e a PIEDCO (BANCO MUNDIAL, 2005, p.14).

Chama a atenção a avaliação positiva feita pelo Banco em relação à parceria entre os setores público e privado, uma vez que, no mesmo relatório, havia sido apontada tanto limitações na autonomia da PIEFZA, quanto o surgimento de uma sobreposição entre as funções da agência e da PIEDCO. No entanto, a própria PIEDCO aponta, como parte de sua contribuição ao relatório de finalização do projeto, que a ZIG representou "um excelente modelo de parceria entre a PIEFZA como uma agência pública e a PIEDCO como um desenvolvedor privado" - modelo que poderia "ser replicado em futuros projetos de zonas industriais na Palestina” (PIEFZA apud BANCO MUNDIAL, 2005, p. 14).

Apesar das dificuldades encontradas, portanto, o Banco faz um balanço positivo do modelo de desenvolvimento industrial estabelecido pela experiência da ZIG, apontando justamente, como um dos impactos positivos gerados pela zona, o "estabelecimento de um 
modelo adequado de desenvolvimento" (BANCO MUNDIAL, 2005, p.11, grifo nosso) e a criação de empregos para os TPO. De acordo com o Banco, a ZIG representou um importante precedente para o desenvolvimento industrial palestino, e ofereceria perspectivas promissoras para o futuro "se os constrangimentos em acesso e mobilidade puderem ser superados" (BANCO MUNDIAL, 2005, p.11) - não necessariamente por meio da soberania palestina, embora ela pudesse ser desejável, mas sobretudo por eventuais acordos entre ocupantes e ocupados para a livre circulação destes.

A iniciativa da Zona Industrial de Gaza, no entanto, parece ter feito pouco para ajudar o pequeno ou médio investidor palestino de Gaza, como foi rapidamente discutido. Beneficiaram-se, sobretudo, elites econômicas palestinas, que possuíam o capital inicial e as conexões necessárias para conseguir operar regularmente na ZIG. Contudo, o caráter transnacional do empresariado palestino da diáspora significava que, em geral, os lucros não eram reinvestidos na economia palestina (HANIEH, 2011). Quando eram, dificilmente se poderia dizer que os investimentos contribuíssem ao fortalecimento econômico palestino: a construção de grandes hotéis e projetos imobiliários são, em geral, os destinos destes investimentos (NAKHLEH, 2004). Via de regra, no entanto, os lucros eram remetidos para "sedes multinacionais e empresas de ações no Golfo" (ADVANI, 2016, p.83), o que se garantia pela legislação posta em prática pela autoridade nacional.

Ao que parece, apesar de seu fraquíssimo desempenho geral, e de não ter auxiliado o pequeno investidor palestino, a iniciativa da Zona Industrial de Gaza foi benéfica à PADICO e, em menor grau, à ANP. O impacto institucional do projeto, como visto, foi elogiado e considerado "substancial" pelo Banco Mundial tanto no setor privado quanto no público. O aprendizado gerado pela ZIG ao setor privado palestino, particularmente à PIEDCO, é destacado - a empresa conseguiu desempenhar tarefas complexas no campo de desenvolvimento e gestão industrial, e a "capacidade” construída através da zona de Gaza seria produtiva no futuro, mesmo em outras áreas (BANCO MUNDIAL, 2005, p.11).

Para além de ter contribuído para a consolidação do poder social de uma elite políticoeconômica palestina - por exemplo da família al-Masri, que controla a PADICO -, a experiência da Zona Industrial de Gaza gerou, como se viu, uma marcante cooperação com o capital israelense, e em diversos momentos mostrou-se benéfica também a ele. $\mathrm{O}$ aprofundamento das restrições e destruições israelenses, após 2000, agravou a dependência palestina já existente em relação a indivíduos e empresas do lado israelense, numa dinâmica em que os efeitos da ocupação tornavam a cooperação com o empresariado de Israel a única opção 
para os "sobreviventes" palestinos. Significativamente, a iniciativa da ZIG serviu ainda ao fortalecimento e aperfeiçoamento, ainda que limitado, da indústria de segurança israelense, diretamente conectada às forças da ocupação da Cisjordânia e de Gaza (ADVANI, 2016).

É significativa a posição do Banco Mundial (e também da PIEFZA), exposta acima, em favor do modelo de desenvolvimento adotado. De fato, a ideia de zonas industriais de exportação, como estratégia para a "paz" e o desenvolvimento, continuaria presente nos TPO e voltaria a ganhar força alguns anos depois, com a consolidação de um projeto neoliberal na ANP e com o apoio internacional recebido pelo Fatah na Cisjordânia, após a cisão de $2007^{83}$. A segunda metade dos anos 2000 ficaram marcados, nos territórios palestinos ocupados, pela consolidação do Fayyadismo como prática de gestão da Autoridade Nacional Palestina. Inspirado no ex-Ministro das Finanças e ex-primeiro-ministro da ANP Salam Fayyad, o termo designa o modelo neoliberal de gestão pública progressivamente internalizado pela ANP ao longo dos anos 2000, que orientou os planos de desenvolvimento nacional e as estratégias para libertação política da autoridade desde então (KHALIDI; SAMOUR, 2011).

Em 2007, foi realizada em Paris uma Conferência de Doadores, voltada essencialmente a angariar e coordenar apoio financeiro aos planos de desenvolvimento de Fayyad. Na conferência, as iniciativas de zonas industriais de fronteira, voltadas à produção para exportação, foram retomadas como estratégia de desenvolvimento (DANA, 2015, p.470) ${ }^{84}$. Projetos de zonas industriais foram, mais uma vez, impulsionados pelos principais atores em questão. Três projetos iniciais foram a Zona Industrial de Jenin, no norte da Cisjordânia; a Zona Industrial de Tarqumiya ao sul, próxima a Hebron; e o "Corredor para a Paz e a Prosperidade" do Vale do Jordão (NAKHLEH, 2012, p. 98). Além destas, duas outras zonas industriais foram ainda construídas ao longo da última década: a Zona Industrial de Belém e a de Tulkarem, ambas localizadas na Cisjordânia. Tariq Dana (2015, p.471) faz um resumo das principais produções em cada zona industrial. Em Jenin, "bens de metal, comidas e bebidas, químicos, cosméticos e materiais de construção"; no Parque Agroindustrial de Jericó, predomina a indústria alimentícia; em Belém, indústrias pequenas e médias, algumas de alta tecnologia; e em Tarqumiya, "empresas de logística e de trânsito, e produção de têxteis e vestimentas".

\footnotetext{
${ }^{83}$ Após a cisão entre Fatah e Hamas, os financiadores internacionais mantiveram-se fortemente comprometidos com a assistência externa à Cisjordânia, em partes como forma de "premiar" o governo da ANP, em oposição ao completo boicote imposto à Faixa de Gaza (HADDAD, 2016).

${ }^{84}$ Todo o movimento de injetar financiamento ao desenvolvimento da Cisjordânia foi uma forma de "premiar" o governo do Fatah, em detrimento do boicote realizado pela comunidade doadora ao Hamas, na Faixa de Gaza (DANA, 2015, p.470).
} 
O Parque Agroindustrial de Jericó - cujo projeto recebeu o nome de "Corredor para a Paz e a Prosperidade" - foi lançado em 2006 pelo governo japonês, como uma iniciativa de cooperação com a ANP e a Jordânia. O parque só iniciou operações em 2015, quando a primeira empresa (Palolea) começou a operar no local, sendo atualmente a maior entre as iniciativas de zonas industriais em atividade (DANA, 2015, p.472). Em 2017, sete fábricas já atuavam no parque, número que passou de dez nos anos seguintes ${ }^{85}$. Segundo vídeo de divulgação, mais de 3400 empregos diretos e 17 mil indiretos haviam sido gerados pela iniciativa até 2017. Embora possa impulsionar a produção agrícola total do Vale do Jordão, ou mesmo de toda a Cisjordânia, o Parque Agroindustrial tem sido alvo de críticas. Em primeiro lugar, a produção da zona industrial é, em partes, exportada para assentamentos israelenses da Cisjordânia (TARTIR, 2012, p.5). O projeto tem sido acusado, também, de ser elitista e seletivo. Os documentos da iniciativa - e mesmo as placas ao redor do perímetro da zona - estão apenas em inglês e japonês, não contendo versões em árabe. Além disso, o projeto exclui pequenos agricultores e investidores, que não têm acesso ao capital e à assistência necessários para iniciar operações no parque. Assim como no caso da ZIG, parece ser sobretudo uma elite econômica palestina familiarizada com redes internacionais de financiamento - que se beneficiam das oportunidades no local (TARTIR, 2012, pp.8-10). As intenções por trás da construção do JAIP se assemelham, de fato, à lógica mais ampla dos esforços de assistência externa dos anos 1990, aqui analisados, demonstrando a continuidade da abordagem neoliberal para a "paz", mesmo após a Segunda Intifada e o bloqueio à Faixa de Gaza. Tartir (2012, p.12) cita as palavras do ministro das relações exteriores japonês, sobre a iniciativa do Parque Agroindustrial de Jericó: "Quando o conceito do Corredor para Paz e Prosperidade estiver materializado, o problema regional será resolvido por meios econômicos, e não de segurança, ou políticos”.

\footnotetext{
${ }^{85}$ Disponível em: 〈https://www.youtube.com/watch?v=HPVWMNNQ94A〉. Acesso em 16 mai. 2019.
} 
Figura 4 - Parque Agroindustrial de Jericó - projeção.

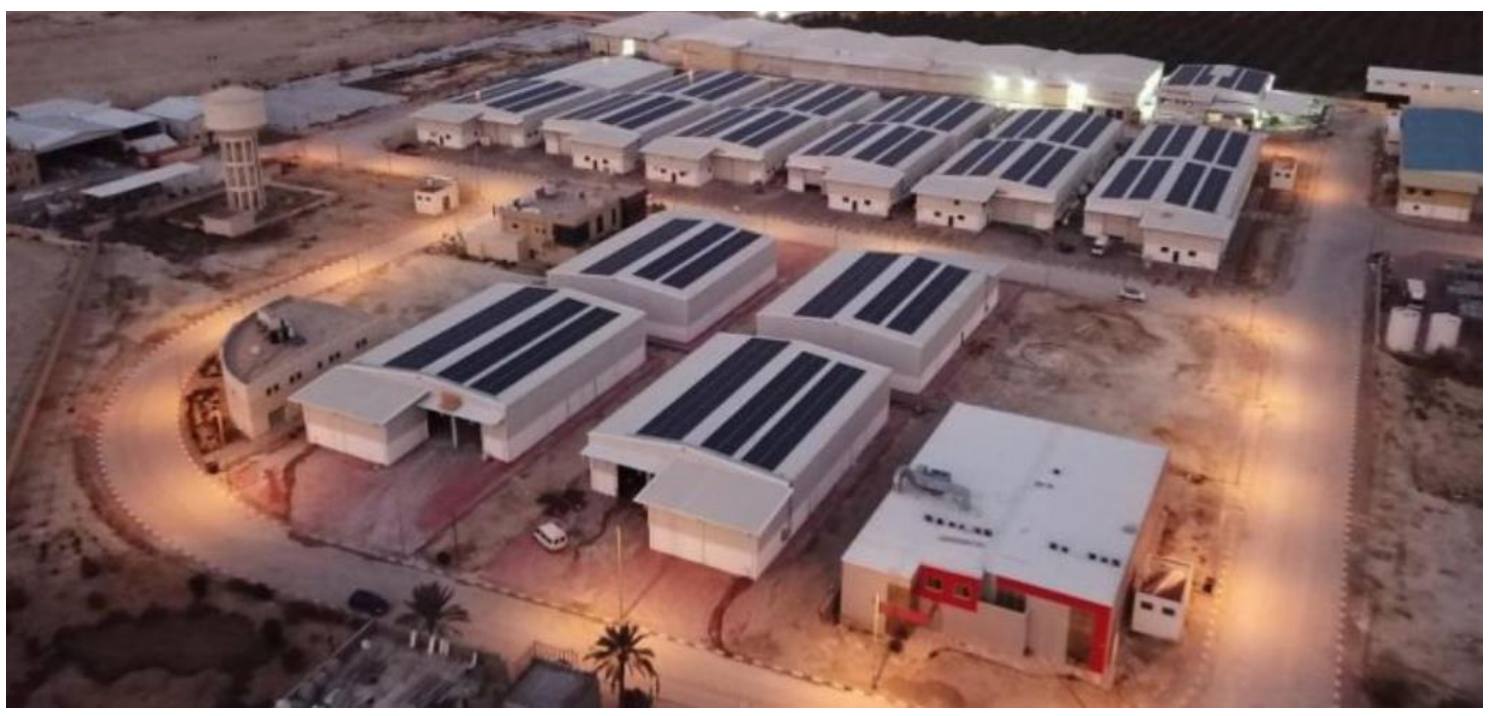

Fonte: PIEFZA, 2020. Disponível em: <https://piefza.ps/gov/?page id=2195>. Acesso em: 16 mai. 2019.

A Zona Industrial de Belém (Bethlehem Multidisciplinary Industrial Estate), financiada pela França e cujas operações se iniciaram em 2013, tem sido acusada de apresentar riscos ambientais, e a maioria dos habitantes locais acreditava, em 2017, que a consolidação e expansão da zona afetaria suas agriculturas (ADVANI, 2017, pp.15-16). No mesmo sentido, a Zona Industrial de Jenin ${ }^{86}$, cujo início de operações estava planejado para 2015, parece ser o pior caso - entre as iniciativas existentes - em termos de apropriação de terras locais pela ANP. (ADVANI, 2017, p.15). Além disso, também é marcadamente presente o risco de confisco de terras por Israel nos parques industriais. Não é raro que as zonas estejam parcialmente localizadas em área $\mathrm{C}$, o que torna mais difícil a obtenção de permissões para construir, e mais presente a vigilância e arbitrariedade das forças da ocupação. Esse é o caso das zonas industriais de Tulkarem e do Parque Agroindustrial de Jericó (ADVANI, 2017, p.19). As zonas industriais são projetos de grande porte, para os quais é necessária não apenas permissões de Israel, mas também o envolvimento de companhias israelenses. A zona de Jenin, por exemplo, tem como principal fornecedor de água a empresa israelense Mekorot (ADVANI, 2017, p.19), o que demonstra novamente a estratégia de desenvolvimento altamente dependente de Israel. Por fim, nas zonas atualmente em operação, assim como na Zona Industrial de Gaza, os trabalhadores palestinos não estão protegidos por leis palestinas ou israelenses - relativas à segurança social, por exemplo -, não podem ser representados por sindicatos dos TPO e tampouco criar

\footnotetext{
${ }^{86}$ Financiada pela assistência financeira turca e alemã (DANA, 2015).
} 
organizações próprias, entre trabalhadores das zonas. Além disso, evidentemente, os trabalhadores desses locais estão sujeitos a rigorosos mecanismos de segurança, para entrada e saída de seus locais de trabalho (DANA, 2015, p.472-473). A multiplicação de zonas industriais para exportação, ao longo dos últimos quinze anos, mostra assim que o modelo de desenvolvimento neoliberal prescrito pela comunidade financeira externa continua tão presente nos TPO quanto estava nos anos de Oslo, se não mais.

\subsection{Reflexões finais: desenvolvimento ou normalização da ocupação?}

Os "processos de paz" estiveram - como discutido acima - intimamente associados com uma marcante recuperação econômica de Israel na década de 1990. Após anos marcados por forte crise econômica e pela necessidade de ajustes, os anos 1990 foram, de fato, a década do "boom" da economia israelense. Entre 1994 e 2000, o PIB de Israel cresceu em 14,2\% e, de acordo com um homem de negócios industriais israelense, citado por Dana (2015, p.463), esta expansão econômica "não teria sido provável antes de os processos de paz começarem". Os acordos de Oslo haviam impulsionado um novo momento no Oriente Médio, as relações econômicas de Israel com alguns dos principais vizinhos haviam sido normalizadas e o capital israelense havia, enfim, se lançado num forte processo de internacionalização. Nesse mesmo período, como abordado, a economia palestina encontrava-se em situações cada vez mais críticas, com um altíssimo desemprego e índices de pobreza crescentes. Os processos políticos não haviam levado a qualquer tipo de soberania ou controle da terra, que, pelo contrário, era cada vez mais tomada por assentamentos em construção, expansão ou simplesmente pelas forças militares (NAQIB, 2003; WEIZMAN, 2007).

É difícil afirmar que, nesse contexto, a experiência da Zona Industrial de Gaza tenha trazido algum tipo de desenvolvimento socioeconômico aos TPO. Quando medida por seus próprios critérios, a iniciativa foi um fracasso admitido, embora o Banco Mundial proponha, como visto, uma revisão nos critérios iniciais e sustente, em 2005, que ter ido adiante com o projeto havia sido a "decisão certa" (BANCO MUNDIAL, 2005, p.14). No auge de seu funcionamento, em meados de 2000, o número de empregos gerados na ZIG não chegava a $10 \%$ da meta total, e com o início da Intifada e das restrições israelenses, como se disse, as atividades da zona se reduziram ainda mais dramaticamente.

Explicitamente filiada aos "processos de paz", desde o início estava evidente que o sucesso da Zona Industrial de Gaza dependeria do sucesso, ao menos parcial, dos arranjos políticos a serem estabelecidos (ou não) entre palestinos e israelenses. O controle das fronteiras 
dos territórios palestinos ocupados, contudo, não esteve na mesa em Oslo, ou em qualquer outra das tentativas de negociação que se deram ao longo dos anos 1990 e 2000. Como visto, os financiadores da ZIG aceitaram a ausência de concessões israelenses e prosseguiram com a iniciativa: mesmo diante da negação de Israel de conceder ao projeto qualquer garantia de livre circulação de bens e pessoas, optou-se por uma zona de fronteira, voltada (parcialmente) para a atração de capital estrangeiro e (completamente) para a exportação. Como consequência, todo o funcionamento da zona falhou, desde o início, em garantir qualquer aumento significativo da produção e do emprego na Faixa de Gaza e, portanto, em promover mesmo o mais limitado processo de desenvolvimento socioeconômico.

Cabe questionar, no entanto, se a ZIG teria trazido desenvolvimento aos palestinos de Gaza caso não tivesse falhado em seus próprios termos, isto é, caso a entrada e saída de produtos da zona tivesse se mantido livre, ainda que sob ocupação contínua. Em outras palavras, parece importante julgar a iniciativa para além de seus próprios critérios, questionando-os e perguntando quem se beneficiaria se eles tivessem sido, de fato, atendidos. Se a Zona Industrial de Gaza fosse bem-sucedida, como esperavam os financiadores do projeto, os resultados seriam um aumento significativo no investimento atraído e nos empregos gerados, impulsionando o crescimento da economia de Gaza. Seus anos de operação, contudo, mostram que em geral as atividades desenvolvidas dentro da zona eram subcontratadas por empresas israelenses, de forma que, mesmo quando as companhias operantes eram palestinas, os baixos custos de trabalho e impostos na ZIG favoreciam, em última instância, firmas israelenses. Além disso, o trabalho palestino empregado era de baixo valor agregado, sobretudo no setor têxtil, e os salários continuavam sendo menores que em Israel.

Na medida em que aprofundam a dependência econômica palestina em relação a Israel, as iniciativas de zonas industriais contribuem antes para o des-desenvolvimento da economia palestina dos TPO do que para seu desenvolvimento. O conceito de des-desenvolvimento, discutido na introdução, aponta para o fato significativo de que crescimento econômico, e mesmo a obtenção de certos níveis de prosperidade, não são sinônimos de desenvolvimento (ROY, 1987; 1999). Esta confusão embasou, nas décadas pós-1967, o discurso de Israel sobre sua ocupação dos TPO, que sublinhava o fato de que as condições econômicas da população palestina dos territórios haviam melhorado após o início da ocupação. De fato, a renda palestina aumentou após 1967, gerando maiores níveis de consumo, e avanços na educação e na saúde também foram obtidos. No entanto, Roy (1987, p.57) ressalta a importância de se analisar esses 
processos, e a extensão de seus impactos na sociedade palestina, a partir "do contexto econômico, social e político da ocupação de forma mais ampla".

Com o início da ocupação, como discutido na introdução, a economia de Gaza foi largamente integrada à economia israelense, tornando-se absolutamente dependente desta. Nos momentos em que o crescimento econômico foi impulsionado, o motor foi sobretudo a economia de Israel, ao passo que os recursos da economia palestina eram progressivamente erodidos por políticas de confiscos, destruições e restrições à atividade econômica dos palestinos. A economia palestina, assim, tem sido privada de "inputs" essenciais, como terra, água, crédito, etc., sem os quais qualquer processo de desenvolvimento de longo prazo estará fadado ao fracasso (TURNER; SHWEIKI, 2014). Consolida-se uma situação, portanto, em que mesmo iniciativas como as zonas industriais, que podem trazer crescimento econômico e alívio ao desemprego no médio prazo, não alterarão as condições estruturantes que determinam o desenvolvimento de longo prazo da economia palestina. De fato, os "processos de paz" de forma geral, e as zonas industriais em particular, não lidaram em nenhum momento com o ponto central da questão entre palestinos e israelenses: a disputa em torno da soberania sobre o território. Consequentemente, não questionaram ou alteraram a "relação de tipo colonial entre as economias palestina e israelense" (NAQIB, 2003, p.501), que se refletiu na experiência da ZIG mesmo em seus melhores momentos.

Nos termos de Tartir (2012, p.13),

[...] qualquer projeto que evite abordar a ocupação, e claramente dar um fim nela, corre o risco de legitimar e perpetuar a ocupação, que é o perigo da abordagem mainstream adotada [...], [que] não pode, em nenhum caso, reverter as tendências de des-desenvolvimento ou introduzir mudanças estruturais reais na economia palestina.

Mesmo que a Zona Industrial de Gaza tivesse sido bem-sucedida em seus próprios termos, é difícil supor que a população da faixa estaria em melhores condições para se auto sustentar ou, centralmente, para resistir à ocupação. As políticas israelenses - que, como indica Roy (1987; 1999), estruturalmente bloqueiam qualquer potencial de desenvolvimento econômico palestino - permaneceriam intocadas: o controle último sobre as fronteiras continuaria com Israel, os assentamentos continuariam se multiplicando e as políticas de expropriação e destruição não seriam desafiadas. Entre a sociedade palestina, como visto, se beneficiaria principalmente uma pequena elite econômica, cujas conexões com a economia dos TPO, até Oslo, eram bastante fracas. Ao invés de fortalecer economicamente a maioria da população palestina local, a zona de Gaza normalizava as relações entre ocupante e ocupado, 
azeitando a cooperação econômica entre os empresariados palestino e israelense, e beneficiando economicamente ambos.

Desde sua concepção, assim, o projeto de zonas industriais nos TPO foi concebido para gerar desenvolvimento econômico apesar da ocupação, não tocando em questões políticas e não visando criar condições para que os palestinos pudessem, de fato, se desenvolver como povo independente. Trata-se de um desenvolvimento que, de certa forma, ignora as estruturas da ocupação israelense, e pretende seguir como se elas não existissem. No entanto, nenhum desenvolvimento pode ocorrer "como se não houvesse nenhuma ocupação" (LAGERQUIST, 2003, p.3). Qualquer transformação estrutural que se busque para a sociedade palestina sob ocupação será, necessariamente e a todo momento, atravessada por relações de dominação política e colonial. Ignorar essas relações só leva à perpetuação da condição de desdesenvolvimento palestina e à normalização de uma situação de ocupação colonial de povoamento, como evidenciou o caso da Zona Industrial de Gaza. 


\section{CAPÍTULO 3: ASSISTÊNCIA INTERNACIONAL E A TRANSFORMAÇÃO NA SOCIEDADE PALESTINA DOS TPO}

\subsection{Introdução}

Nos últimos capítulos, foram analisadas algumas transformações econômicas que a comunidade de assistência financeira internacional, liderada pelo Banco Mundial, tem trazido aos territórios palestinos ocupados como resultado dos "processos de paz". Enfatizou-se a concepção e as práticas neoliberais de desenvolvimento socioeconômico que foram priorizadas, seus descolamentos em relação à realidade palestina de ocupação militar e colonização contínuas, e sua incapacidade de entregar os resultados socioeconômicos prometidos, mesmo segundo os critérios estabelecidos pelos próprios financiadores. Até aqui, o foco da discussão esteve em projetos mais imediatamente econômicos, embora parte central do argumento tenha sido que estas operações são, também, inerentemente políticas. Neste capítulo, continua-se a explorar os efeitos da assistência financeira internacional aos TPO, a partir dos "processos de paz”. Contudo, enfatiza-se agora um outro lócus, menos propriamente econômico, em que transformações em chave neoliberal também podem ser observadas: as práticas de organização e atuação social das populações palestinas da Cisjordânia e da Faixa de Gaza. Busca-se, assim, reforçar a concepção sobre o neoliberalismo debatida na introdução, compreendendo-o como um fenômeno que ultrapassa a dimensão estritamente econômica e opera transformando diferentes esferas da vida individual e coletiva.

Parte dos montantes destinados aos territórios palestinos em assistência financeira, nos anos que se seguiram aos acordos de Oslo, tinha como objetivo auxiliar e fortalecer organizações sociais palestinas, notadamente organizações não governamentais, enquanto agentes importantes nos processos de desenvolvimento que, argumentava-se, eram fundamentais para atingir a "paz". Em partes, esse renovado auxílio internacional à sociedade dos TPO expressou-se pela mobilização - cada vez mais frequente a partir dos anos 1990 - da noção de uma "sociedade civil palestina" presente nos territórios. Até então, o conceito de sociedade civil era pouco utilizado para se referir às diferentes organizações, mais ou menos “políticas”, que compunham a sociedade palestina local (CHALLAND, 2005, pp.56-57; 2009). A ascensão da noção de sociedade civil, nos anos 1990 - em sintonia com seu avanço em todo o mundo, como será discutido adiante -, gerou controvérsia entre intelectuais e militantes palestinos. Em geral, foi questionada a adequação do conceito para um contexto como o vivido pelas populações da Cisjordânia e da Faixa de Gaza. A noção de uma sociedade civil remete diretamente à dicotomia entre sociedade e Estado, e os palestinos nunca chegaram a ter um 
Estado (e tampouco o teriam como resultado de Oslo). O termo tampouco foi originalmente concebido para descrever sociedades sob ocupação, ou submetidas a um projeto colonial em andamento (DANA, 2015, pp. 191-192). Seu uso para a Palestina, assim, poderia antes esconder a realidade colonial existente do que colocá-la em primeiro plano.

No debate sobre a aplicabilidade do conceito de sociedade civil à realidade palestina da Cisjordânia e da Faixa de Gaza, dois campos se consolidaram. O primeiro, pelas razões mencionadas, opunha-se à utilização do termo, associando-o aos discursos liberais de peacebuilding e statebuilding da comunidade de assistência externa. Uma segunda posição, embora também denuncie as práticas dos financiadores internacionais e reconheça a instrumentalização do conceito, sustenta a existência de uma sociedade civil palestina, na medida em que compreende a noção como o resultado da necessária agremiação dos seres humanos em sociedade. Esta corrente aponta para as inúmeras especificidades da "sociedade civil palestina", frutos de uma trajetória histórica peculiar, mas mantém o conceito para afirmar uma esfera de autonomia social e econômica palestina - e, por isso, de potencial resistência política e anticolonial (CHALLAND, 2009; DANA, 2014; 2015, pp.191-192).

Embora o conceito de sociedade civil não se esgote em sua mobilização neoliberal, discutida em mais profundidade na próxima seção, e embora sejam importantes as mobilizações do termo que enfatizem sua dimensão emancipatória, nessa dissertação não se utilizará o conceito para se referir à sociedade palestina dos TPO ou a suas diferentes práticas de associação. Parte importante do argumento avançado até aqui envolveu afirmar a dimensão política de esferas da vida social às quais, em geral, não se costuma atribuir carga política marcante. Mais do que isso, como será discutido nesse capítulo, desde 1967 as associações e grupos palestinos atuantes na Cisjordânia e Faixa de Gaza - incluídos num conceito de "sociedade civil palestina" - atuaram de formas eminentemente (e muitas vezes declaradamente) políticas. A sociedade palestina dos territórios esteve, desde o início da ocupação israelense, profundamente imbricada com a resistência anticolonial - quando não confrontando diretamente as forças da ocupação, atuando para proteger e fortalecer seus setores mais vulneráveis na luta contra elas.

Diante desse cenário, a mobilização do conceito de sociedade civil para os palestinos dos TPO - na medida em que sublinha (e se sustenta em) uma separação entre esferas/formas políticas e não políticas de associação/organização social - parece antes tomar como dados efeitos que, em realidade, foram produzidos pelos novos arranjos dos "processos de paz". A "sociedade civil palestina" foi, historicamente, mobilizada nesses termos num movimento de 
diferenciação (embora nem sempre de oposição) em relação à ANP, que surgia como novo "Estado" a regular a vida das populações locais (vale lembrar, em áreas A e B, apenas). Para além do que aqui se considera uma mobilização neoliberal do conceito de "sociedade civil palestina" pelas agências financiadoras, a noção foi também mobilizada, no contexto dos “processos de paz" e da iminência de surgimento da ANP, por figuras de facções minoritárias da OLP, que passaram a atuar em conjunto com ONGs locais para afirmar uma "sociedade civil palestina" dos territórios, isto é, uma dimensão associativa separada e independente da nova autoridade (HAMMAMI, 1995, pp.51-53). É difícil, contudo, estabelecer em que ponto deve ser traçada a linha divisória entre o político e o "civil", ou o "não político", e qualquer resposta a essa questão parece arbitrária. Sobretudo, não é plausível afirmar qualquer esfera da vida em sociedade que não se assente em arranjos políticos, que não exista em dinâmica com uma realidade política - para reproduzi-la ou contesta-la (FOLEY; EDWARDS, 1996, pp.45-47).

Assim, aqui se utilizará unicamente a ideia de "sociedade palestina" dos TPO para se referir a grupos e associações variadas, existentes nas vilas e cidades palestinas dos TPO, englobando de sindicatos a associações estudantis; de cooperativas de mulheres a organizações religiosas beneficentes; de pequenas comunidades de bases a movimentos sociais mais amplos, passando pelas organizações não governamentais - que, como será visto, ganham forte protagonismo a partir dos anos 1990. Defende-se aqui que essas diferentes associações atuaram de forma política ao longo das suas décadas de existência, e mesmo quando não buscavam fazêlo de forma explícita, estavam posicionadas diante de uma correlação de forças também eminentemente políticas, que ajudavam a combater ou a reproduzir. Contudo, em que pese as problematizações teóricas sobre o conceito de "sociedade civil palestina", a proliferação de seu uso pela comunidade de assistência externa ao longo dos anos 1990 torna sua mobilização em chave neoliberal um objeto interessante de análise. Como será explorado neste capítulo, essa noção passou a ser mobilizada por atores como o Banco Mundial e a USAID para descrever uma esfera específica de intervenção da comunidade doadora internacional, isto é, uma dimensão da realidade social palestina dos territórios que, assim como a economia ou as estruturas estatais, também precisava ser "desenvolvida".

Neste capítulo, assim, analisa-se o financiamento da comunidade de assistência externa às organizações sociais palestinas dos TPO - sobretudo a organizações não governamentais locais, que se tornaram o grande foco de intervenção dos doadores -, dando atenção à mobilização do conceito de "sociedade civil palestina" nesse contexto. Argumenta-se a existência, ao longo das últimas décadas, de diferentes "versões" da sociedade palestina - 
separadas por um processo estrutural de transformação (DANA, 2015) que, como será exposto, teve como um de seus principais vetores a comunidade doadora internacional e como um de seus instrumentos a noção de "sociedade civil palestina". Busca-se rastrear os eixos gerais dessa transformação, analisando os dispositivos - do próprio conceito de uma "sociedade civil palestina" a ser desenvolvida, aos critérios de financiamento a certos modelos de organização, passando pela difusão de noções como advocacy e empoderamento - que impulsionaram numa certa direção as formas de associação palestinas locais. Argumenta-se que o sentido da transformação social observada esteve em sintonia com tendências neoliberais do período, e sobretudo que tais transformações afetaram de forma negativa as capacidades de resistência da sociedade palestina a um projeto colonial de povoamento. A próxima seção discute rapidamente o conceito de sociedade civil, especificamente sua ascensão no final do século XX e suas articulações com o avanço do neoliberalismo no período. Em seguida, são expostas as principais características da sociedade palestina sob ocupação, nas décadas que antecedem aos “processos de paz". O restante do capítulo, então, analisa a concepção e implementação de um processo específico de desenvolvimento da sociedade (civil) palestina a partir dos anos 1990, focando novamente na participação do Banco Mundial como agente importante deste processo, mas observando também o caso da USAID, que foi particularmente importante para a difusão do termo no contexto analisado.

\subsection{A sociedade civil neoliberal}

A emergência do conceito de sociedade civil nas últimas décadas do século passado tem, em partes $^{87}$, relação com as transformações em curso na ordem econômica e política internacional do período, isto é, com a emergência do neoliberalismo como novo paradigma político e econômico. Como abordado anteriormente, as últimas décadas do século XX foram de profunda reestruturação nas funções atribuídas ao Estado, que deixou de ser compreendido como fonte prioritária de provisão de serviços sociais e como ator principal na busca por "desenvolvimento". Nesse cenário, não foi apenas o "setor privado" que, como debatido no primeiro capítulo, passou a se encarregar dos objetivos anteriormente assumidos pelo Estado: a própria sociedade se tornou uma esfera para onde tais responsabilidades passaram a ser

\footnotetext{
${ }^{87}$ A ascensão do termo também esteve relacionada a experiências de resistência a regimes totalitários no Leste Europeu e na América Latina. Tendo origem no pensamento de Antônio Gramsci, essa segunda acepção - que inspirou a mobilização pelas facções minoritárias da OLP, no contexto estudado -, afirma a sociedade civil como um lócus separado do Estado e com potencial de resistência às forças estatais e contestação à hegemonia predominante (DANA, 2014; ALASHQAR, 2018).
} 
transferidas (BECKMAN, 1993; DANA, 2014; VELTMEYER, 2008). Se, até os anos 1970, o "Estado desenvolvimentista" era responsável pelo desenvolvimento nacional e pela proteção da sociedade contra as forças de mercado, sob o novo paradigma neoliberal a responsabilidade de sobreviver à competição capitalista (agudizada pelo próprio neoliberalismo) é transferida aos indivíduos (DARDOT; LAVAL, 2016) e às organizações da própria sociedade. É nesse sentido que Veltmeyer (2008, p. 229) afirma que a emergência e progressiva aplicação da noção de sociedade civil pode ser vista, no contexto neoliberal, como também um processo de privatização.

Em termos concretos, a privatização de serviços sociais - como saúde e educação básica - ocorreu paralelamente a um outro processo, de organização institucional da sociedade em associações voltadas à realização de certos objetivos sociais, como a alimentação de pessoas em situação de rua, a proteção do meio ambiente, a defesa dos direitos das mulheres, etc. (VELTMEYER, 2008). É nesse contexto que a noção de sociedade civil é resgatada em chave neoliberal, não apenas como um ente autônomo ao Estado - e por isso intocado por suas ineficiências - e ao mercado, mas sobretudo como um parceiro fundamental destes na realização do "projeto de desenvolvimento" (PARPART, VELTMEYER, 2004). O conceito de sociedade civil, assim, torna-se peça importante dos paradigmas de desenvolvimento elaborados a partir do final do século XX, já em chave neoliberal (BECKMAN, 1993; DANA, 2014; VELTMEYER, 2008).

Como abordado, a emergência do neoliberalismo não se restringiu a processos de liberalização econômica, mas englobou também significativas transformações na gestão política da vida em sociedade. Sobretudo após o fim da Guerra Fria, a expansão da democracia liberal refletiu-se na reestruturação institucional de Estados visando maiores níveis de participação, o que se atingiria por meio de descentralização administrativa e maiores complementaridades entre Estado, mercado e sociedade. Entre os conceitos mobilizados, para dar conta deste terceiro elemento na tríade do projeto neoliberal, estavam noções como a de sociedade civil. Central na provisão de serviços sociais anteriormente garantidos pelo Estado, a sociedade civil teria também, assim, uma função eminentemente política de democratização: ao participar na concepção, decisão e implementação de políticas públicas (policies), as organizações da sociedade civil tornariam o processo de desenvolvimento mais democrático e transparente (EDWARDS, 2014). A sociedade civil havia sido parte da derrubada de várias ditaduras e, por meio dela, o Estado democrático poderia, uma vez estabelecido, ser tornado permanentemente accountable. Essa função política da sociedade no governo democrático está 
incluída na noção de boa governança - discutida no primeiro capítulo - que emerge de forma paralela à de sociedade civil nos anos 1990 (VELTMEYER, 2008).

A obra do cientista político norte-americano Robert Putnam pode ser apontada como um dos principais exemplos dessa mobilização contemporânea da noção de sociedade civil. O bom funcionamento da democracia não é possível se as práticas democráticas se encerrarem dentro das estruturas estatais e político-partidárias. As organizações da sociedade civil - mesmo as menos intuitivamente públicas, como ligas de boliche, corais e grupos de observação de pássaros - possuem uma função a cumprir na governança democrática (PUTNAM, 1995). É a existência de densas redes associativas, para além das esferas do governo e do mercado, que garantem a manutenção de níveis adequados de participação e pressionam o Estado a seguir padrões eficientes e transparentes na condução dos negócios públicos (PUTNAM, 1993).

A sociedade civil, na acepção neoliberal, afirma assim a potência de uma relação de complementaridade entre Estado, mercado e sociedade. Em outros termos, a sociedade civil tem como função "melhorar" o funcionamento do Estado e garantir certos serviços à população. A premissa, aqui, é de avanço progressivo, de melhoria incremental por meio de uma relação sinérgica entre mercado, Estado e organizações civis (EDWARDS, 2014). Qualquer possível dimensão de resistência radical aos dois primeiros, ou de questionamento a sistemas ou estruturas políticas e econômicas predominantes, não encontra lugar na acepção neoliberal de sociedade civil (ALASHQAR, 2018; DANA, 2014). Concretamente, movimentos sociais e organizações de classe anteriormente existentes, com posições anti-sistêmicas, perdem importância diante da emergência de instituições temáticas, que visam sobretudo a mudança dos indivíduos - por meio do "empoderamento", por exemplo -, a realização de direitos individuais ou setoriais e a disputa de espaços dentro das estruturas estabelecidas de poder, mais do que a transformação dessas mesmas estruturas (VELTMEYER, 2008).

É a partir dessa chave de interpretação que o conceito de sociedade civil é incluído no novo paradigma de desenvolvimento, que passa a ser propagado por instituições financeiras internacionais como o Banco Mundial, no final do século passado. Tratava-se, no caso do Banco, de uma tentativa de incorporar dimensões mais propriamente sociais e políticas na concepção de desenvolvimento defendida - em partes, como visto, uma tentativa de aplacar os efeitos nocivos gerados pela própria abordagem neoliberal de ajuste, impulsionada nas décadas anteriores (PEREIRA, 2014). O processo de desenvolvimento, nesse contexto, precisaria ocorrer mais "de baixo para cima", com participação ativa e parcial responsabilidade dos agentes locais da sociedade (além, é evidente, do setor privado). 
Como afirmado, um setor particular da sociedade civil recebeu ênfase significativa nessa nova mobilização do conceito por discursos do desenvolvimento: as organizações não governamentais. A expansão meteórica do modelo de ONG como forma de organização social ocorreu a partir dos anos 1980, e continuou nas décadas seguintes (CHOUDRY; KAPOOR, 2013). Instituições como o Banco Mundial incorporaram como parte integral de seus projetos de desenvolvimento a participação do "terceiro setor" (HOWELL, 2000). Mais importante, organizações não governamentais passaram a receber grandes quantias em financiamento externo, fortalecendo-se enquanto sólidas parceiras locais dos projetos de desenvolvimento (PETRAS, 1999). Esse processo, frequentemente referido como "ONGuização", frequentemente ocorreu em paralelo ao referido enfraquecimento de movimentos e organizações de classe (JALALI, 2013). Consolidaram-se, como pilar da sociedade civil neoliberal, organizações institucionalizadas e profissionais, voltadas a pequenos grupos de interesse ou temas específicos, cujo horizonte de transformação social encerra-se dentro das fronteiras da democracia liberal e dos arranjos econômicos neoliberais, e cujas bases sociais de apoio são sobretudo classes médias urbanas internacionalizadas (ABDO, 2010; VELTMEYER, 2008).

É nesse amplo contexto que se insere a assistência financeira oferecida pelo Banco Mundial e pela USAID ao setor de ONGs palestinas e à "sociedade civil palestina" da Cisjordânia e da Faixa de Gaza, a partir dos anos 1990. Como será analisado, ambos os atores foram responsáveis por impulsionar uma versão específica do que deve ser a "sociedade civil palestina" dos territórios, quais são suas tarefas perante o Estado (no caso, a autoridade nãosoberana) e a economia e, talvez mais importante, quais capacidades era preciso desenvolver para atingir seus objetivos de longo prazo. Argumenta-se que, aliados à alta dependência dos TPO em relação à assistência externa - em partes resultante dos próprios “processos de paz" , o modelo de atuação social e a concepção de sociedade civil impulsionados pela comunidade doadora internacional foi responsável por uma marcante transformação nas organizações da sociedade palestina dos TPO (ALASHQAR, 2018; DANA, 2014; 2015). Neste capítulo, buscase analisar os eixos gerais desse processo de transformação a partir de projetos do Banco Mundial e da USAID, enfatizando alguns efeitos que a versão neoliberal de sociedade civil traz para uma população cuja realidade é marcada pela ocupação militar e pela imposição de um projeto colonial de povoamento (WOLFE, 2016). 


\subsection{A sociedade palestina dos TPO antes de Oslo}

Para analisar as transformações impulsionadas pelos "processos de paz" e pelo financiamento externo na sociedade palestina dos TPO, é importante observar quais eram, em linhas gerais, as características dessa sociedade e seus modelos predominantes de atuação social no período que antecede aos anos 1990. Ao longo do século XX, os diferentes regimes que dominaram a Cisjordânia e a Faixa de Gaza determinaram, em grande medida, as possibilidades de associação nos territórios. A primeira lei a prever o direito de associação foi estabelecida pelos otomanos em 1907, determinando a obrigação de associações de declararem previamente seus objetivos, sendo a permissão para existir condicional à aprovação do governo central. O objetivo da lei, no contexto em que foi criada, era conter o emergente nacionalismo árabe, de forma que associações de caráter nacionalista eram proibidas. Como resultado, predominou no período o surgimento de organizações voltadas à caridade, frequentemente de cunho religioso, estabelecidas e lideradas pelos "notáveis". Muitas dessas organizações continuaram atuantes até os anos 1990 e depois (CHALLAND, 2009, pp. 59-60).

Sob o mandato britânico, uma lei de 1922 passou a regular a existência de associações não voltadas à geração de lucros. Menos restritiva que a lei otomana, a nova regulação levou à multiplicação de associações palestinas, embora em ritmo marcadamente menor do que seria observado após $1948^{88}$. Os anos 1950 e 1960 representaram, na luta nacional palestina, uma significativa mudança de liderança. Se até a Nakba a resistência havia sido sobretudo liderada por "famílias aristocráticas urbanas" (KHALIDI, RASHID, 2006, p. 142), frequentemente lideranças religiosas, a partir dos anos 1950 o cenário se alterou, com a emergência de partidos como o Fatah e, na década seguinte, a Frente Popular para a Libertação da Palestina e a Frente Democrática de mesmo nome. Emergiu, assim, uma liderança palestina mais jovem, de origem diversa, nacionalista e baseada em política de massa (KHALIDI, RASHID, 2006).

Com a ocupação da Cisjordânia e da Faixa de Gaza pelas Forças de Defesa Israelenses em 1967, os direitos de associação dos palestinos dos territórios passaram a ser regulados pela Ordem Militar Israelense ${ }^{\circ} 686$. Num sentido semelhante ao da lei otomana de 1907, a ordem militar proibia a existência de qualquer associação civil ou política sem a aprovação prévia da nova Autoridade Civil da ocupação. Na prática, a nova lei significava que os partidos políticos estavam banidos dos territórios, assim como qualquer organização de caráter explicitamente nacionalista (CHALLAND, 2009, p.61; SCHULZ, 2013, p.247). Como resultado, a OLP

\footnotetext{
${ }^{88}$ Entre as ONGs atuantes nos territórios ocupados em 2009, apenas 3,4\% eram anteriores a 1948 (CHALLAND, 2009, p.60).
} 
passou a atuar da Jordânia, e as forças que compunham o movimento de libertação nacional passaram a usar organizações locais, que permaneceram nos territórios ou foram criadas após 1967, para articular a resistência local.

Nas décadas que se seguiram à ocupação israelense, partidos como o Fatah, a FPLP, a FDLP e o Partido Comunista Palestino ${ }^{89}$ influenciaram sindicatos, cooperativas, organizações estudantis, profissionais, comunitárias, de mulheres, entre outras (DANA, 2015; CHALLAND, 2009; MUSLIH, 1993). Ao mesmo tempo em que proviam serviços concretos às populações palestinas, essas diferentes organizações compreendiam como parte central de sua tarefa mobilizar e organizar os palestinos na resistência contra a ocupação colonial israelense mesmo que, na maioria dos casos, o objetivo nacional não pudesse ser plenamente publicizado. Assim, desde os anos 1960 - década de criação da OLP - foram profundas as relações entre esta (por meio dos partidos que a compunham) e organizações de base dos territórios ocupados (ALASHQAR, 2018; CHALLAND, 2009). Nesse sentido, Alashqar (2018) expõe uma série de atividades "políticas" nas quais se envolviam as organizações da sociedade palestina dos TPO, com o objetivo de fortalecê-la no combate à ocupação israelense e na luta por libertação. Entre as principais iniciativas estavam a educação política das crianças e jovens palestinos, de cidades e vilas dos territórios, sobre temas como o sionismo, a ocupação, a história da Palestina e os objetivos nacionais; ações combinadas de boicote e desobediência, como greves, boicotes de produtos e cortes israelenses; promoção de produtos palestinos; boicote ao pagamento de impostos às autoridades da ocupação; organização de protestos; além da provisão de serviços de saúde, educação e bens de consumos básicos a setores marginalizados.

Sobre a influência dos partidos políticos nas organizações da Cisjordânia e da Faixa de Gaza no período que se seguiu à ocupação, Challand (2009, p.61) dá o exemplo do setor de saúde. Entre 1979 e 1989, foram criados quatro comitês e conselhos civis de trabalhadores da saúde, cada um deles afiliado - ou politicamente alinhado - a um partido distinto da OLP. Situações semelhantes se verificavam em outros setores, como educação e agricultura. A sociedade palestina das décadas de 1970 e 1980, assim, era "profundamente enraizada no movimento de libertação nacional" (DANA, 2015, p.191). Além da compreensão de suas atividades como eminentemente políticas, outras características das organizações da sociedade palestina chamam a atenção quando comparadas ao período pós-Oslo. Em primeiro lugar, cabe destacar a estrutura altamente descentralizada das organizações, característica marcante até o

\footnotetext{
${ }^{89}$ O Partido Comunista Palestino não fazia parte da Organização para a Libertação da Palestina (OLP).
} 
fim da Primeira Intifada (DANA, 2015). Tratava-se, sobretudo, de movimentos e associações de base, bastante capilarizados nas vilas e cidades da Cisjordânia e de Gaza e capazes de envolver e mobilizar em suas atividades parcelas significativas das comunidades locais. Além da alta presença na base e da baixa centralização, as organizações concebiam e planejavam suas iniciativas a partir de uma compreensão de longo prazo. Como afirmado, mesmo as tarefas mais imediatas - como a provisão de alimentos ou serviços de saúde - eram inseridas numa concepção maior sobre o que significava a condição palestina, e sobre qual a estratégia para superá-la.

As organizações palestinas, assim, compreendiam-se e atuavam como vetores de um processo fundamentalmente político de fortalecimento dos palestinos na resistência à ocupação colonial e na luta pela independência nacional. Não à toa, termos como "resiliência", "fïmeza" e "resistência" eram comumente mobilizados para se referir às características desta sociedade que precisavam ser fortalecidas na luta contra a colonização sionista. Como será discutido adiante, com o início dos "processos de paz", termos como estes perderam espaço e foram substituídos por novos conceitos, como "transparência", "accountability", "advocacy" e "empoderamento". Essa mudança lexical está relacionada não apenas às transformações pelas quais passou a sociedade palestina desde os anos 1990 (DANA, 2015), mas também à emergência, abordada na seção anterior, de um discurso neoliberal global sobre a função da sociedade civil no desenvolvimento (VELTMEYER, 2008), que teve como vetores importantes atores como o Banco Mundial e a USAID.

As duas décadas após a ocupação israelense foram de multiplicação nas associações locais palestinas, não apenas como instrumento de politização da população pelos partidos da OLP, mas também como forma de compensar, ainda que parcialmente, a ausência de serviços públicos e infraestruturas estatais (CHALLAND, 2009). As organizações e associações palestinas dos TPO cumpriram, como dito, um papel fundamental na resistência à ocupação iniciada em 1967, em geral colocando-se como parte integrante da luta cotidiana dos palestinos dos territórios - por exemplo, auxiliando financeiramente famílias de presos políticos palestinos - e posicionando-se, dessa forma, "na linha de frente da luta anticolonial" (DANA, 2015, p.193).

A década de 1980 marcou uma nova transformação na liderança política palestina. Desde 1982, a OLP estava mais distante que nunca dos territórios ocupados, atuando a partir de Túnis ${ }^{90}$. Na Cisjordânia e na Faixa de Gaza, duas décadas de ocupação militar, expropriação,

\footnotetext{
${ }^{90}$ Como resultado da invasão israelense do Líbano, em 1982, a OLP foi expulsa de Beirute.
} 
controle e repressão contínuos não eram aliviados por ganhos econômicos relativos - advindos, como visto, de uma relação de profunda dependência econômica com Israel. Uma nova liderança emergia, sobretudo a partir de campos de refugiados nos TPO (PAPPE, 2006, pp. 230-235), e em partes por meio de organizações islâmicas nacionalistas como o Hamas, criado no início da Primeira Intifada. Como resultado, a OLP viu diminuir progressivamente seu controle sobre os eventos que se desenrolavam nos territórios ocupados.

Os anos da Primeira Intifada representaram um ápice na organização local da população palestina dos TPO, o que se refletiu na proliferação de organizações locais, ainda mais intensa que nos anos anteriores (CHALLAND, 2009) ${ }^{91}$. Visando o boicote aos produtos e empresas israelenses (por meio de greves coordenadas, por exemplo) e a autossuficiência econômica e alimentar palestina, associações de vários tipos surgiram nas vilas e cidades dos territórios - e, novamente, de forma marcante nos campos de refugiados, locais históricos de politização e auto-organização na sociedade palestina (PAPPE, 2006, pp.230-235). Embora as novas lideranças continuassem, em geral, associadas a algum partido da OLP, a liderança da organização sobre a resistência palestina nos TPO estava sem dúvida enfraquecida. Assim, ao longo da Intifada, as organizações e associações palestinas tornaram-se os principais vetores de organização das populações locais. Essa perda relativa de controle sobre os rumos da luta nacional foi um dos vários fatores que levaram o Fatah a buscar como estratégia, nos anos 1990, o estabelecimento de "processos de paz" negociados com Israel (KHALIDI, RASHID, 2006).

\subsection{A assistência externa à sociedade palestina dos TPO nos anos de Oslo}

Na virada das décadas de 1980/90, com o fim da Guerra Fria e a consolidação do neoliberalismo enquanto novo paradigma global, os principais conflitos armados, as principais ameaças à estabilidade e segurança internacionais passaram a vir sobretudo de conflitos internos a Estados falidos. É nesse contexto que, como discutido anteriormente, ganham força operações de peacebuilding, peacekeeping e statebuilding, apoiadas por instituições internacionais como a ONU, o Banco Mundial e o FMI. Tratavam-se de intervenções internacionais, visando não apenas resolver conflitos sociopolíticos locais, mas fazê-lo através da inserção, nas sociedades afetadas, das estruturas sociais, políticas e econômicas consideradas mais adequadas à

\footnotetext{
${ }^{91}$ Das ONGs atuantes em 2009, quase metade (47,5\%) foram criadas entre 1967 e 1993 . Somente durante os anos da Intifada (1987-93) foram 18,8\% (CHALLAND, 2009, p.62).
} 
estabilização - que, apontava-se, seria obtida através da liberalização econômica e política (PARIS, 1997; 2002).

Entre 1989 e 1999, quatorze operações de peacebuilding foram iniciadas pelas Nações Unidas. Em geral, o objetivo de recuperar as instituições estatais e economias destruídas pelo conflito passou pela difusão, a nível local, dos modelos da democracia liberal e da economia de mercado (ALASHQAR, 2018, p.5). A busca por transformar as sociedades afetadas pelos conflitos passava, em geral, por impulsionar o surgimento de novos modelos de organizações e associações não estatais que, como abordado anteriormente, tinham na concepção neoliberal de desenvolvimento um papel central para o bom funcionamento das estruturas de governo. Notase presente, aqui, o objetivo de "engenharia sociopolítica" representado pelo neoliberalismo enquanto prática social (HARRISON, 2004, p.5), discutido na introdução: busca-se, de fato, transformar de maneira holística o Estado, a economia e a sociedade desses locais afetados por conflitos, no intuito de induzir localmente maiores níveis de pacificação e estabilização (social, política e econômica).

Como exposto na primeira seção, é nesse período de avanço neoliberal, de forte descrença na capacidade do Estado de liderar processos de desenvolvimento socioeconômicos, que a noção de sociedade civil volta a emergir. Enfatizam-se, nesse momento, as tarefas nas quais organizações civis podem complementar ou mesmo substituir o Estado (BECKMAN, 1993; VELTMEYER, 2008). Trata-se, como visto, de uma concepção da sociedade civil enquanto intermediária entre as instituições estatais e as forças de mercado, enquanto corpo que funciona em sintonia com Estado e mercado em processos de desenvolvimento (EDWARDS, 2014). Em termos concretos, essa nova ênfase na importância da sociedade civil se refletiu, como visto, na proliferação de organizações não governamentais, na medida em que a própria noção de sociedade civil foi se tornando sinônimo de terceiro setor (JALALI, 2013). ONGs eram vistas como mais eficientes, menos custosas, mais participativas e mais flexíveis que burocracias estatais, cada vez mais em descrédito no enquadramento neoliberal (DANA, 2014; 2015).

Em suma, uma agenda passa a ser avançada por meio de operações internacionais de resolução de conflitos e construção estatal e implementada através de projetos locais de desenvolvimento socioeconômico e reforma institucional. Essa agenda com frequência mobiliza o conceito de sociedade civil, como visto, como um dos elementos chaves de um arranjo sintonizado com a economia de mercado e com um modelo especificamente neoliberal de Estado. Dana (2015) compreende o conceito de sociedade civil, nesse contexto, em partes 
como um "instrumento" para implementação de reformas neoliberais. Petras (1999), em sentido semelhante, aponta a expansão das ONGs a partir dos anos 1990 como um movimento do imperialismo voltado a reorganizar as sociedades em bases compatíveis com sistemas democráticos capitalistas, assim enfraquecendo movimentos sociais de base que fossem radicalmente contrários a tais sistemas (JALALI, 2013; VELTMEYER, 2008). Atualmente, tornou-se de fato ampla a literatura que aponta a instrumentalização do conceito de sociedade civil como maneira de expandir internacionalmente o modelo neoliberal de Estado (CHANDLER, 2010; HARRISON, 2004; LEWIS, 2001; WALLACE, 2009). Lewis (2001), por exemplo, se refere à existência de uma "agenda da boa governança", em sentido semelhante, embora menos crítico, ao mobilizado por Harrison (2004), que aponta o surgimento dos "Estados governança" em países africanos como resultado da atuação sistemática do Banco Mundial no continente, desde a década de 1990. No restante deste capítulo, busca-se explorar como esse discurso e essa prática neoliberais sobre a sociedade civil - e sobre sua inserção em processos de desenvolvimento e governança - foram operacionalizados pelo Banco Mundial e pela USAID, e aplicados aos TPO no contexto dos “processos de paz".

No início da década de 1990, foi registrado declínio significativo no auxílio financeiro externo às organizações não governamentais operantes nos TPO, na contramão do que se observava em relação à assistência financeira geral para os territórios, que, como visto anteriormente, aumentou de forma marcante no período (BRYNEN, 2000; CHALLAND, 2009). De acordo com estimativas do Banco Mundial, no início da década as ONGs palestinas dos TPO recebiam, de fontes externas, entre 140 e 250 milhões de dólares anuais. Nos anos que se seguiram ao início dos “processos de paz”, esse valor diminuiu significativamente: em 1994, o apoio externo foi estimado em 90 milhões; em 1995 e 1996, cerca de 60 milhões; em 1997, o financiamento internacional às ONGs palestinas havia caído para aproximadamente 30 milhões de dólares (BANCO MUNDIAL, 1997a, pp.5-6). A redução foi causada por dois fenômenos. De um lado, como explorado anteriormente, o início da Guerra do Golfo havia significado a interrupção de fluxos financeiros aos TPO, vindos de países árabes até então apoiadores da causa palestina e de remessas de trabalhadores palestinos que viviam nos países do Golfo. De outro, a criação da ANP em 1994 fez com que os fluxos de assistência financeira destinados aos territórios passassem a ser, em grande medida, direcionados para auxiliar o estabelecimento institucional da autoridade. Diante deste cenário de declínio nos "canais tradicionais", o Banco Mundial enfatizou em 1997 a necessidade de "novas fontes de fundos" para o setor de ONGs palestino (BANCO MUNDIAL, 1997, p.6). 
Apesar da redução observada no financiamento externo, com o início dos "processos de paz" a comunidade de assistência externa passou a promover uma série de atividades, voltadas às organizações palestinas - e, de forma mais ampla, à "sociedade civil palestina" -, que buscavam difundir, nestas, valores e práticas de democracia, cidadania e profissionalismo. Multiplicaram-se seminários, conferências, workshops e materiais impressos de divulgação, abordando temas como direitos de minoria, o papel do cidadão, formas democráticas de governo, a função da sociedade civil, técnicas de advocacy e gestão de projetos (HAMMAMI, 1995, p. 1). No mesmo período, registrou-se um aumento expressivo no número de associações e redes formadas por ONGs atuantes nos $\mathrm{TPO}^{92}$. A mais antiga dessas associações, já existente no início da década, era a União de Sociedades Beneficentes, que em 1993 contava com pouco menos de 400 membros. Em 1994, uma nova rede foi criada. Denominada "Rede ONG Palestina", em três anos contava com cerca de 80 organizações participantes. Entre 1996 e 97 , ainda, mais três associações semelhantes foram estabelecidas: a Board Union of Palestinian NGOs (com mais de 200 membros, quando de sua criação); a General Union of Palestinian NGOs (com 68 membros); e o Palestinian National Institute for NGOs (cuja reunião de inauguração contou com a presença de cerca de 250 ONGs locais) (BANCO MUNDIAL, 1997a, p.6).

Desde o início dos “processos de paz”, o Banco Mundial e a USAID estiveram entre os principais financiadores de projetos voltados ao fortalecimento das organizações palestina dos TPO, sobretudo as ONGs. Seguindo o recorte desta pesquisa, as próximas seções analisam em detalhes dois projetos do Banco Mundial para os territórios palestinos ocupados: os projetos ONG Palestina I, de 1997, e II, de 2001. Embora menor em valor que os projetos da USAID para o desenvolvimento das ONG palestinas, as iniciativas do Banco foram inovadoras em termos de desenho, e expressam de forma particularmente nítida os processos de transformação social que se busca destacar neste capítulo. Como será discutido, a participação da USAID nos esforços para o desenvolvimento da "sociedade civil palestina" dos territórios ocupados também foi central nos anos 1990. A agência norte-americana esteve entre os primeiros atores da comunidade de assistência externa a se engajar no tema da "sociedade civil palestina" e de seu "desenvolvimento", mobilizando o uso do termo alguns anos antes do Banco Mundial e, como citado, desembolsando altos montantes de ajuda direcionados ao tema. Por esses motivos,

\footnotetext{
92 O Banco Mundial estimava, para o ano de 1995, a existência de aproximadamente 1200 organizações palestinas cuja atuação nos TPO era voltada para a prestação de serviços à população. Além destas, contabilizavam-se cerca de 200 ONGs internacionais de mesmo tipo (BANCO MUNDIAL, 1997a, p.5).
} 
nas próximas seções a análise dos projetos do Banco Mundial será complementada pela observação de iniciativas levadas a cabo pela USAID para desenvolver a "sociedade civil palestina" dos territórios ocupados da Cisjordânia e Faixa de Gaza.

\subsection{O Projeto ONG palestina}

O "Projeto ONG palestina I" foi lançado em 1997, com previsão para durar até 2003. Totalizava um valor de 17 milhões de dólares em assistência financeira, sendo 10 milhões vindos em formato de bolsa do Fundo de Confiança para a Cisjordânia e a Faixa de Gaza e, portanto, aprovados pelo Banco Mundial (BANCO MUNDIAL, 1997a, p.1). O projeto tinha três "objetivos chave": (i) prover serviços para os setores mais pobres da população palestina dos territórios; (ii) desenvolver "as capacidades institucionais das ONGs" beneficiadas; e (iii) “fortalecer a relação de trabalho" entre as ONGs operantes nos TPO e a Autoridade Nacional Palestina (BANCO MUNDIAL, 1997a, p.2) ${ }^{93}$. De forma mais ampla, o projeto contribuiria, argumenta-se, para dois objetivos estratégicos do Banco Mundial nos TPO: "Alívio da pobreza" e "Promoção de boa governança" (BANCO MUNDIAL, 1997a, anexo 1, p.1). O relatório de apreciação da iniciativa pelo Banco busca localizar o projeto ONG palestina I dentro da participação mais ampla do Banco em projetos de desenvolvimento nos TPO no período ${ }^{94}$ : a busca por melhoria da governança e por combate à pobreza eram considerados dois dos três objetivos estratégicos gerais do Banco para os territórios, sendo o terceiro deles - o incentivo ao setor privado - o único objetivo que não seria diretamente beneficiado pelo projeto (BANCO MUNDIAL, 1997a, p.5).

Tais finalidades seriam perseguidas por meio de quatro modalidades de financiamento: "bolsas de desenvolvimento"; "bolsas de dificuldade (hardship) "; "bolsas de construção de capacidades e pesquisa"; e, por fim, financiamento à coordenação entre as ONGs e a ANP e ao estabelecimento de legislação adequada ao setor. As bolsas de desenvolvimento eram, de longe, a maior parte do projeto, totalizando 10 milhões de dólares e correspondendo a 59\% do custo total. Nessa categoria, as bolsas variavam de 5 mil a um milhão de dólares, e voltavam-se à

\footnotetext{
${ }^{93}$ No Anexo I do documento de apreciação do projeto pelo Banco Mundial, expõe-se uma lista mais detalhada de objetivos e resultados esperados, cada um com os respectivos "Indicadores Chave de Performance" e mecanismos de monitoramento previstos. Para cada objetivo ou resultado esperado do projeto, ainda, o documento descreve os principais riscos envolvidos (BANCO MUNDIAL, 1997a, anexo I, pp.1-2).

${ }^{94} \mathrm{O}$ Banco Mundial havia atualizado, no ano anterior ao projeto, a avaliação estratégica sobre sua participação geral nos TPO. Dois documentos de 1996 resumem essa nova elaboração: "A Cisjordânia e a Faixa de Gaza: a Resposta do Banco Mundial para a Crise Econômica Atual", de abril, e "Reabastecendo o Fundo de Confiança para a Cisjordânia e a Faixa de Gaza", de dezembro.
} 
provisão de serviços sociais em setores como educação, saúde e agricultura. Embora a maior parte dos recursos fosse destinada diretamente a projetos específicos, também foram oferecidas "bolsas em bloco", “[...] concedidas a ONGs experientes e profissionais, para repasse a organizações menores e mais novas” (BANCO MUNDIAL, 1997a, p.2).

As duas outras categorias de bolsas, de "dificuldade" e "construção de capacidades e pesquisa", representavam respectivamente $10 \%$ e $9 \%$ dos custos totais do projeto. A primeira modalidade voltava-se a ONGs em crise financeira, e seria oferecido como "parte de um plano acordado de recuperação financeira”. As bolsas de pesquisa e construção de capacidades, por sua vez, seriam majoritariamente ${ }^{95}$ oferecidas a "instituições ou indivíduos qualificados para conduzir atividades de construção de capacidades com ONGs palestinas, para desenvolver a habilidade destas de planejar, gerir e monitorar projetos" (BANCO MUNDIAL, 1997a, p.2). O quarto componente do projeto, voltado à coordenação ONGs-ANP e ao desenvolvimento de legislação adequada, representava apenas $1 \%$ dos gastos totais $(0,2 \text { milhões })^{96}$.

Para alocação das bolsas, o Banco Mundial determinou o estabelecimento de um “processo de concessão [...] aberto, não partidário e competitivo" que, na visão da instituição, "ajudaria a elevar os padrões profissionais das ONGs" - sobretudo devido à "atenção especial que seria dada, no projeto, à gestão financeira e accountability" (BANCO MUNDIAL, 1997a, p.3). Os critérios de seleção das beneficiárias são estabelecidos no documento de apreciação do projeto pelo Banco:

(i) [...] devem ser organizações não governamentais e não voltadas ao lucro [...] [que] precisarão operar de acordo com as leis relevantes; (ii) [...] devem ser capazes de demonstrar $[\ldots]$ que elas podem gerir dinheiro de uma maneira transparente e eficiente; (iii) devem concordar com os princípios operadores do projeto. Estes incluem a busca de objetivos não políticos humanitários e de desenvolvimento [...] e aderência aos procedimentos de aquisição e contabilidade do projeto; (iv) Porque os subsídios visam apoiar programas de desenvolvimento social e econômico, eles não serão oferecidos a projetos que têm como principal objetivo a promoção de qualquer ponto de vista político ou religioso particular (BANCO MUNDIAL, 1997a, p.4).

\footnotetext{
${ }^{95}$ De 1,5 milhões destinados à categoria "bolsas de pesquisa e de construção de capacidades", dois terços (um milhão de dólares) seriam destinados à construção de capacidades, nos termos citados. O restante iria para (i) o financiamento de pesquisa ( 0,3 milhões) "para melhorar informação e análise sobre o setor de ONGs e/ou para beneficiar as relações de ONGs com a AP" (BANCO MUNDIAL, 1997a, p.2) e (ii) a construção de capacidades da Organização de Gestão de Projetos (OGP) (0,2 milhões), ONG que centralizaria a gestão do projeto como um todo.

${ }^{96} \mathrm{O}$ restante dos custos previstos ( $21 \%$ ou 3,5 milhões) seriam destinados a gastos gerais envolvidos na gestão do projeto como um todo.
} 
No trecho, fica evidente a pressão existente, no novo ambiente institucional pós-Oslo, para que as ONGs palestinas não fossem próximas de organizações políticas. O perfil visado, sugere-se, é do profissional, especialista técnico em assuntos importantes para o desenvolvimento socioeconômico e político-institucional dos territórios palestinos.

Embora estabelecido pelo Banco, o projeto ONG palestina teve as tarefas de divulgação, seleção de ONGs, coordenação, desembolso e supervisão terceirizadas para uma "Organização Gestora do Projeto" (OGP) - "um consórcio de ONGs selecionada por competição internacional aberta, com base em experiência e competência provadas". No desenho do projeto, a terceirização visava "garantir objetividade não-partidária no processo de concessão" de financiamento (BANCO MUNDIAL, 1997a, p.3). O Banco manteria, contudo, poder de veto sobre a seleção das ONGs - sua "não objeção" era obrigatória, e visava "garantir que o devido processo e a imparcialidade foram observados no processo seletivo" (BANCO MUNDIAL, 1997a, p.4).

Ainda sobre a seleção de beneficiários, o Banco afirma que um "processo consultivo amplo seria estabelecido", com o objetivo de "garantir que subprojetos de ONGs não dupliquem atividades existentes e sejam responsivos a necessidades da comunidade" (BANCO MUNDIAL, 1997a, p.4). O processo consistiria numa série de reuniões públicas, a serem organizadas pela OGP antes de cada rodada de concessão de bolsas, em diferentes partes dos TPO. Com participação do Comitê de Coordenação Local de Ajuda, e do Ministério do Planejamento e de Cooperação Internacional da ANP, as reuniões serviriam como espaço para ouvir acerca das necessidades locais e "obter orientação sobre áreas e setores que deveriam ter prioridade na próxima rodada de bolsas” (BANCO MUNDIAL, 1997a, p.4). Após a seleção de ONGs beneficiadas, uma segunda fase do processo consultivo seria iniciada: por meio de reuniões com o MPCI e outros ministérios relevantes, a OGP se certificaria de que as ONGs e os subprojetos selecionados não resultariam na duplicação de atividades já sendo realizadas pela ANP. Por fim, a OGP consultaria o Banco Mundial para obter a "não objeção".

Para além do processo consultivo envolvendo as ONGs candidatas ao financiamento (e, na segunda fase, aquelas selecionadas), o Banco Mundial sugere que o desenho do projeto, como um todo, garantiria que as ONGs beneficiadas tivessem uma conexão significativa com as comunidades para as quais ofereceriam serviços sociais:

Potenciais beneficiárias de bolsas precisariam demonstrar apoio comunitário para todos os subprojetos, incluindo na maioria dos casos apoio financeiro da comunidade; isso ajudaria a garantir que subprojetos respondam a prioridades da comunidade (BANCO MUNDIAL, 1997a, p.3). 
O projeto previa uma contribuição de 700 mil dólares vindos das comunidades beneficiadas, valor que deveria ser levantado e canalizado, como visto, por meio das organizações selecionadas pelo projeto (BANCO MUNDIAL, 1997a, p.9). Para além do apoio financeiro vindo das comunidades, contudo, não são explicitadas por quais outras maneiras as organizações palestinas precisariam “demonstrar apoio comunitário”, como condição para receber o financiamento.

A respeito dos processos de contabilidade e monitoramento a governarem o projeto, é enfatizada a busca por promover "padrões saudáveis de gestão financeira", de forma que todas as organizações inscritas no processo seletivo "deveriam estar preparadas para ter seus livros financeiros inspecionados pela OGP”. Às ONGs selecionadas, a OGP exigiria a entrega de "documentos anuais profissionalmente auditados, mostrando como os fundos do projeto foram administrados" (BANCO MUNDIAL, 1997a, p.4). A própria organização gestora do projeto teria, também, de entregar relatórios periódicos ao Ministério das Finanças da ANP e ao Banco Mundial. Os documentos seriam avaliados por auditores internacionais, sintonizados com os padrões de gestão financeira da instituição (BANCO MUNDIAL, 1997a, p.5).

\subsubsection{A Organização Gestora do Projeto: A Associação Welfare (AW)}

No processo seletivo para Organização Gestora do Projeto ONG palestina I, cinco consórcios de organizações foram selecionados pelo Banco para uma lista final. Além do Consórcio Associação Welfare (CAW) - que, por ter se saído vitorioso, será objeto de análise mais detida nesta seção -, os outros quatro finalistas envolviam duas ONGs norte-americanas atuantes nos territórios ocupados ${ }^{97}$; um consórcio entre duas ONGs europeias de filiação religiosa e duas ONGs palestinas ${ }^{98}$; bem como um consórcio entre uma universidade palestina (Birzeit) e o Save the Children (dos EUA e do Reino Unido) (NAKHLEH, 2012, pp. 199-201). Por fim, o Consórcio Associação Welfare - que eventualmente obteve o direito de gerir o projeto - era composto por duas instituições britânicas ${ }^{99}$ e a Associação Welfare (AW) que, além de dar nome ao consórcio, era de longe sua principal líder e "parceira crítica, em termos desse projeto e da antecipação do Banco em relação a ele" (NAKHLEH, 2012, p.201). Como ficará evidente por meio de uma rápida descrição da Associação Welfare - da história de sua atuação e de seus principais líderes -, a escolha da organização para gerir o projeto ONG

\footnotetext{
${ }^{97}$ CARE e World Learning (NAKHLEH, 2012, p.199).

98 Denominado Consórcio CIBG, formado por: Christian Aid, ICCO, Bisan Center e the Galilee Society (NAHKLEH, 2012, p.199).

${ }^{99}$ Charities Aid Foundation e British Council (NAKHLEH, 2012, p.199).
} 
palestina I é expressiva dos rumos que o Banco Mundial buscava dar às formas de associação entre os palestinos dos TPO.

A Associação Welfare foi estabelecida na Suíça em 1983, após a invasão israelense do Líbano, destruição das instituições palestinas ali existentes e transferência da OLP para a Tunísia. A organização foi fundada por quatro empresários palestinos da diáspora: Hasib Sabbagh, Abdel Majeed Shoman, Abdel-Mohsen Qattan e Munib al-Masri - fundador e atual presidente da PADICO, abordada no capítulo anterior. Diante da destruição causada por Israel, o objetivo era construir, de fora da Palestina, uma organização que funcionasse como a instituição de desenvolvimento "pública" palestina, auxiliando os palestinos não apenas nos territórios ocupados, mas também em campos de refugiados da região, por exemplo (NAKHLEH, 2012, pp.182-186).

Como discutido no capítulo anterior, os principais nomes do grande empresariado palestino da diáspora mantiveram relações próximas com a liderança da OLP, frequentemente atuando como canais de comunicação (e negociação) entre figuras como Arafat e governos norte-americanos e árabes, por exemplo. Nos primeiros dez anos da associação, Nakhleh (2012) cita alguns exemplos que demonstram a busca da Associação Welfare por se aproximar do Fatah e da liderança da OLP, favorecendo-a e, por vezes, boicotando ativamente investimentos a organizações locais próximas de outros partidos da OLP, como a Frente Popular. Os grandes empresários palestinos da diáspora - dentre os quais os fundadores e então diretores da AW foram também articuladores importantes dos "processos de paz" e atuaram como negociadores da OLP nesse contexto (NAKHLEH, 2012, pp.190-193).

Com a perspectiva de criação de uma autoridade nacional autônoma, esse grande empresariado visou não apenas aprofundar seus investimentos lucrativos nos territórios - como visto no dos al-Masri, com a PADICO -, mas também se localizar como mediador dos investimentos internacionais em assistência, cujos montantes como visto se elevariam a partir de Oslo. Nesse sentido, com o início dos "processos de paz" e o estabelecimento da ANP, a Associação Welfare se consolidou como uma das principais agências a realizar um importante papel de mediação com financiadores internacionais de projetos de assistência (aid-brokering), funcionando como um canal para os montantes destinados ao desenvolvimento dos TPO (NAKHLEH, 2012, pp.190-193).

Nos anos que se seguiram a 1993, a AW moveu-se para os territórios ocupados, e o ONG palestina esteve - juntamente com um projeto em Jerusalém - entre os dois primeiros grandes projetos da associação. Dentre os finalistas do processo seletivo para gerir o projeto, 
mencionados acima, pode-se afirmar que o Consórcio Associação Welfare era a organização mais estreitamente alinhada à liderança da nova ANP, cuja liderança estava mais envolvida em seu processo de construção e de construção dos novos arranjos político-econômicos de Oslo, de forma geral. No caso de nenhum dos outros competidores, por mais extensas que fossem suas operações nos TPO, o envolvimento com o novo regime estabelecido com os "processos de paz" era tão profundo (NAKHLEH, 2012, pp. 200-201). A seleção da organização pelo Banco Mundial, dessa forma, expressa a intenção de fortalecer nos TPO organizações palestinas que estivessem dispostas a atuar dentro dos limites previstos pelos arranjos de Oslo

O ONG Palestina I recebeu uma boa avaliação pelo Banco Mundial. Como resultados da iniciativa, afirma-se que mais de cem mil palestinos marginalizados dos TPO haviam sido beneficiados indiretamente, através dos serviços prestados pelas organizações financiadas. O número esteve muito acima da meta inicial de alcance do projeto, que visava atingir 50 mil pessoas (BANCO MUNDIAL, 2001, p.14). Diante da avaliação positiva feita dos quatro anos de projeto, em 2001 o Banco Mundial aprovou a realização de uma segunda fase: o "ONG palestina II".

\subsubsection{A segunda fase (2001-2004)}

O Projeto ONG palestina II, para o qual o Banco Mundial aprovou uma bolsa de 8 milhões de dólares (BANCO MUNDIAL, 2001, p.1), foi concebido visando "construir a partir das realizações e sucessos" da fase anterior (BANCO MUNDIAL, 2001, p.2). Com um valor total de 16 milhões, o projeto foi planejado para ser um "programa amplo de construção de capacidade" (BANCO MUNDIAL, 2001, p.2, grifo no original), tendo como objetivo principal

[...] fortalecer a capacidade de Organizações Não Governamentais (ONGs) de entregar serviços sustentáveis aos palestinos pobres e marginalizados, ao mesmo tempo apoiando o desenvolvimento profissional e estratégico geral do setor de ONGs palestino (BANCO MUNDIAL, 2001, p.2, grifo nosso).

Embora concebido em continuidade à iniciativa de 1997, a segunda fase do projeto realiza importantes ajustes de desenho, expressando uma ênfase muito mais pronunciada na sustentabilidade de longo prazo do "setor de ONGs" palestino, como se pode perceber no trecho acima. A ênfase no desenvolvimento setorial está associada a um foco - também marcante e mais presente que na primeira fase - na noção de construção de capacidades dentro das organizações beneficiadas. Ainda na seção de objetivos, afirma-se a intenção de "apoiar uma transformação de longo prazo do setor de ONGs para um que seja dinâmico e apto a responder às necessidades mutáveis da sociedade palestina" (BANCO MUNDIAL, 2001, p.2). O Banco apresenta na segunda fase, assim, uma "abordagem mais ampla para construção de capacidades, 
que coloca ênfase em planejamento estratégico, construção de cenário, advocacy, aprendizagem e networking” (BANCO MUNDIAL, 2001, p.4)

O projeto de 2001 também reflete, de forma significativa, a emergência do conceito de sociedade civil nos projetos do Banco Mundial para a sociedade palestina dos TPO: o termo está ausente do documento da primeira fase, e apresenta 12 ocorrências no mesmo documento, de apreciação, da segunda fase. Ao abordar como o projeto "ONG palestina II" se relacionava com a "estratégia" mais geral do Banco para os $\mathrm{TPO}^{100}$, o documento aponta que,

[...] ao facilitar maior clarificação de uma visão compartilhada do setor de ONGs, e ao melhorar sua capacidade de cumprir seu papel mais efetivamente, o projeto vai contribuir para apoiar o desenvolvimento de uma sociedade civil sólida - um elemento fundamental da boa governança e de uma transformação saudável em direção à condição de Estado ${ }^{101}$ (BANCO MUNDIAL, 2001, p.3).

Concretamente, os ajustes de ênfase e desenho se expressaram em mudanças nas modalidades de financiamento. Uma nova categoria - "bolsas de parceria" - passou a representar 55\% dos custos totais (9,5 milhões de dólares), sendo destinada a ONGs "líderes" que, através do estabelecimento de consórcios com ONGs e organizações comunitárias de base (OCBs), repassariam os fundos a subprojetos locais (BANCO MUNDIAL, 2001, p.3). O objetivo era financiar entre cinco e oito consórcios, com bolsas no valor médio de um milhão de dólares, visando construir "uma relação de acompanhamento de longo prazo entre ONGs grandes/capazes e ONGs/OCBs pequenas” (BANCO MUNDIAL, 2001, p.30).

A introdução das "bolsas de parceria" na segunda fase do projeto moveu-se pela compreensão de que, enquanto a primeira fase havia estabelecido como indicador de impacto o número de pequenas ONGs atingidas, o ONG palestina II deveria ser direcionado pela qualidade, e não quantidade dos resultados atingidos. A ênfase em grandes ONGs, enquanto intermediadoras de projetos levados a cabo por organizações comunitárias menores, tinha dois objetivos principais. O Banco identificava, em 2001, uma forte "concentração das atividades de ONGs em áreas urbanas” (BANCO MUNDIAL, 2001, p.3), bem como

[...] a concentração de 50\% dos fundos disponíveis para o setor de ONGs nas mãos de umas poucas ONGs. Isso reflete, ao menos em parte, lacunas consideráveis na capacidade das ONGs em diferentes níveis e indica uma necessidade de ampliar o que é, agora, uma base bastante limitada de ONGs competentes e funcionais (BANCO MUNDIAL, 2001, p.4).

\footnotetext{
${ }^{100}$ Estratégia de Assistência ao País/Country Assistance Strategy (CAS).

${ }^{101}$ No original, "statehood".
} 
Diante destes diagnósticos, as bolsas de parceria visavam, por um lado, auxiliar as ONGs grandes e profissionais dos territórios a estabelecer redes e a aumentar seu alcance em comunidades não urbanas. Por outro, buscava-se impulsionar a capacidade de ONGs menores e locais e sintonizá-las com práticas internacionais de gestão de projetos de desenvolvimento, facilitando assim o acesso de longo prazo dessas ONGs locais ao financiamento internacional (BANCO MUNDIAL, 2001, p.36). O objetivo, em suma, era superar a lacuna identificada estabelecendo estreitas conexões de trabalho entre as ONGs urbanas, profissionais e bem financiadas e as organizações locais e menos estruturadas.

A modalidade majoritária de bolsas na primeira fase - bolsas de desenvolvimento também esteve presente no projeto de 2001, embora representando apenas 15,6\% dos custos totais (contra 59\% na fase anterior). Para além da redução de orçamento, na segunda fase as bolsas de desenvolvimento deixaram de ser "abertas" a qualquer ONG que se aplicasse, tornando-se restritas a organizações já beneficiadas pelo projeto anteriormente. Projetava-se financiar, sob essa categoria, entre 10 e 15 projetos de ONGs "que demonstraram performance excepcional" (BANCO MUNDIAL, 2001, p.28) e "habilidade de gerir projetos de qualidade durante a Fase 1" (BANCO MUNDIAL, 2001, p.5). O valor planejado dos projetos a serem financiados por bolsas de desenvolvimento era entre 50 e 300 mil dólares (BANCO MUNDIAL, 2001, p.5).

A manutenção das bolsas de desenvolvimento se justificava pelo importante papel que as ONGs palestinas continuavam a cumprir no que tange aos serviços prestados às populações dos territórios, mesmo diante da existência já consolidada da autoridade palestina. De acordo com o Banco Mundial, em 2001 o setor de ONGs palestino era responsável por $60 \%$ dos serviços de atenção básica em saúde, $42 \%$ dos hospitais, $90 \%$ dos centros de reabilitação e $95 \%$ das escolas primárias, sendo também fundamental na assistência à agricultura palestina nos TPO (BANCO MUNDIAL, 2001, p.3). Para além da provisão concreta de serviços, o relatório ressalta a longa experiência das ONGs palestinas em lidar com as necessidades das populações locais, bem como a capacidade que as organizações tinham de atingir os setores mais marginalizados da sociedade palestina. Tratava-se assim, na visão do Banco, de um setor com alto enraizamento e com "a flexibilidade de se adaptar a condições mutáveis e situações de emergência" (BANCO MUNDIAL, 2001, p.3).

Contudo, em 2001 o Banco identificava uma série de fatores que ainda impediam a “efetividade do setor" (BANCO MUNDIAL, 2001, p.3) nos TPO, justificando a ênfase em desenvolvimento setorial da segunda fase do projeto. Além das limitações no financiamento 
externo e do predomínio de uma perspectiva de caridade, pouco estratégica ou sustentável, o Banco aponta a insuficiência na troca de informações e coordenação geral entre as diferentes redes de ONGs, e entre estas e o setor público, isto é, as agências e ministérios da ANP. A relação do setor de ONGs com a autoridade, assim como na primeira fase, continua a ser um dos alvos de intervenção do projeto. O Banco faz uma leve crítica à ANP, afirmando que ela inicialmente "foi, em geral, relutante em aceitar o fato de que não é a única força motora do desenvolvimento" (BANCO MUNDIAL, 2001, p.4). Assim, nos primeiros anos após a criação da ANP, sua relação com as ONGs teria sido "caracterizada por competição e rivalidade" (BANCO MUNDIAL, 2001, p.4). Em partes como fruto da primeira parte do projeto $^{102}$, uma "relação de trabalho mais saudável" havia sido desenvolvida, e em 2001 o relatório aponta que "hoje tanto as ONGs quanto a AP reconhecem que possuem papéis complementares a cumprir"103 (BANCO MUNDIAL, 2001, p.4).

De fato, uma lei regulamentando a atividade das ONGs havia sido aprovada dois anos antes, em 1999, e foi positivamente avaliada pelo Banco como um indicativo de que a ANP estava disposta a respeitar e incentivar o "crescimento independente contínuo do setor" (BANCO MUNDIAL, 2001, p.4). No mesmo ano, também um Ministério de ONGs foi estabelecido pela autoridade palestina, e em suas primeiras manifestações havia se demonstrado disposto a "melhorar a complementaridade entre os [...] respectivos papéis" do setor público e do setor de ONGs (BANCO MUNDIAL, 2001, p.4). A noção de "complementaridade" entre os setores é, de fato, bastante presente no relatório da segunda fase (BANCO MUNDIAL, 2001, pp.5; 7; 13), num deslocamento em relação ao projeto de 1997 , onde o termo não é mobilizado nenhuma vez.

Portanto, a segunda fase do projeto buscava aprofundar um processo de transformação setorial que, acreditava-se, havia sido iniciado com o ONG palestina I. Um dos componentes do projeto de 2001, como afirmado acima, era um "programa de apoio ao setor" cujo objetivo era "apoiar a elaboração de uma visão mais forte do papel do setor no desenvolvimento e seu envolvimento na definição de política (policy)" (BANCO MUNDIAL, 2001, p.5). Esse componente do projeto visava "promover um ambiente de trabalho positivo para o diálogo

\footnotetext{
102 O Banco considera uma das "realizações chave da Fase 1 a contribuição para ampliar as oportunidades de diálogo entre as redes de ONGs e a AP, em grande medida por meio da estrutura da Mesa de Governança Consultiva" (BANCO MUNDIAL, 2001, p.5). O objetivo era que o estabelecimento de uma Mesa de Supervisão, na segunda fase, cumprisse essa função de estabelecer espaços constantes de diálogo entre o setor de ONGs e a ANP.

${ }^{103}$ Embora o relatório também afirme que "a relação [...] ainda é caracterizada por uma mistura de desconfiança, controle e cooperação" (BANCO MUNDIAL, 2001, p.6).
} 
AP/ONG e para melhorar complementaridade entre programas públicos e não governamentais de serviços públicos" (BANCO MUNDIAL, 2001, p.5). Em termos concretos, apontavam-se a realização de seminários e workshops, não apenas como forma de melhorar a coordenação e diálogo interno do setor, mas também para promover nele uma "cultura de aprendizado" (BANCO MUNDIAL, 2001).

A ênfase na qualidade dos resultados, que marca a segunda fase, levou também a uma nova abordagem para o desembolso dos valores financiados. Embora seja característico dos projetos do Banco a divisão em etapas e a liberação gradual de fundos, no relatório de 2001 há um destaque marcante - ausente da primeira fase - para a conexão entre monitoramento de projetos financiados e liberação de fundos subsequentes. Afirma-se, nesse sentido, que a OGP deve dividir as bolsas concedidas em parcelas, e assim "conectar desembolsos ao alcance de certos resultados" (BANCO MUNDIAL, 2001, p.10). O objetivo, para além de aumentar a efetividade final do projeto, era impulsionar a "cultura de aprendizado" e as "melhores práticas do setor" (BANCO MUNDIAL, 2001, p.22). Nota-se aqui, mais uma vez, a busca por transformar internamente as condutas das organizações palestinas, instilando nelas critérios de desempenho e modelos de atuação estabelecidos pelos financiadores - isto é, afinados ao paradigma neoliberal do período.

\subsection{A USAID e a "sociedade civil palestina" dos TPO}

Pode-se perceber, da análise dos projetos ONG palestina I e II, a intenção do Banco Mundial de efetivamente transformar a cultura organizativa, as estruturas e práticas das organizações palestinas da Cisjordânia e da Faixa de Gaza. Igualmente, foi brevemente apontada, na análise dos documentos dos projetos, a emergência do conceito de sociedade civil como parte dos discursos do Banco para os TPO, entre a primeira e a segunda fase do "ONG palestina”. Como afirmado anteriormente, contudo, o Banco Mundial não esteve entre os primeiros membros da comunidade de assistência financeira internacional a mobilizar a noção de uma "sociedade civil palestina" como concepção importante e, em certa medida, organizadora da assistência a ser oferecida às organizações da sociedade palestina. Nessa seção, enfatiza-se a participação de um dos atores responsáveis por essa mobilização inicial do conceito: a USAID. Argumenta-se que, embora com ênfases distintas daquelas presentes nos projetos do Banco Mundial, as iniciativas da agência norte-americana para as organizações palestinas dos TPO também contribuíram para impulsionar processos de transformação 
neoliberal na sociedade palestina - transformações para as quais o conceito de uma "sociedade civil palestina" foi instrumental.

O primeiro programa da USAID para o desenvolvimento da "sociedade civil palestina" dos TPO foi aprovado já em 1995, entrando em vigor no ano seguinte. Sob o título "Construindo uma sociedade civil informada e ativa na Cisjordânia e na Faixa de Gaza”, o financiamento da agência direcionou-se ao programa "Fórum Cívico", voltado essencialmente à "educação cívica" das populações palestinas dos TPO. Sobretudo, a iniciativa visava impulsionar o conhecimento dos palestinos acerca de valores e práticas democráticas. Concretamente, o programa consistiu na realização de sessões periódicas de discussão com membros de organizações civis palestinas, moderadas por palestinos treinados em educação cívica, sobre direitos e deveres do cidadão, práticas democráticas representativas e participativas, entre outros (NDI, 1999, p. 2).

O fortalecimento da "sociedade civil palestina" para atuação política democrática esteve no centro dos esforços de assistência da USAID, com uma ênfase muito menor que a do Banco Mundial na provisão, por meio das ONGs, de serviços sociais concretos. A abordagem da agência visava sobretudo a educação das associações palestinas, que, por sua vez, eram vistas como vetores essenciais de transformação para suas próprias comunidades locais. O objetivo último era fazer com que a sociedade civil dos TPO conhecesse seus direitos, os problemas que enfrenta, suas posições acerca de questões públicas e as maneiras institucionalmente adequadas para levar adiante tais posições. Sobretudo, tratava-se de transformar a "sociedade civil palestina" em uma defensora ativa de suas posições diante do "governo" - no caso, a recémcriada ANP. Enraizando nos grupos sociais palestinos a compreensão sobre como um governo democrático deve funcionar, buscava-se construir uma sociedade capaz de demandar seus direitos perante o novo "Estado", denunciar práticas impróprias e participar ativamente da formulação e implementação de políticas públicas (policies). A USAID compreendia que, com a formação da ANP, as associações civis palestinas iriam se tornar cada vez menos importantes no fornecimento direto de serviços: ao invés disso, projetava-se que a atuação delas se daria cada vez mais em interface com autoridade, isto é, garantindo práticas democráticas nas estruturas da ANP e oferecendo inputs para a formulação de políticas adequadas (NDI, 1999).

O projeto de educação cívica lançado em 1996 teve duração de dois anos, após os quais o "Fórum Cívico" se tornou uma organização palestina independente, pronta para multiplicar de forma autônoma e permanente os efeitos de seu estabelecimento. A avaliação foi de que o projeto deu frutos: “[...] participantes do Fórum Cívico irão, com maior probabilidade do que 
não participantes, entender e aplicar princípios democráticos, e serão mais inclinados a usar diálogo e compromisso para resolver disputas" (NDI, 1999, p.2). O projeto finalizado em 1998 serviria como base para, poucos anos depois, o lançamento de novas iniciativas, mais amplas e estruturadas, de fortalecimento da "sociedade civil palestina".

Em 2000, a USAID lançou um novo programa voltado ao tema. Totalizando 33 milhões de dólares e cinco anos de duração, o projeto foi nomeado "Tamkeen" - "Empoderamento", em árabe. Num panfleto de divulgação, resume-se o objetivo geral da iniciativa: "trabalhar com grupos da sociedade civil para promover governança mais democrática e accountable na Cisjordânia e na Faixa de Gaza" (USAID, 2004, p.3). Assim como o projeto de 1996 e o "ONG palestina II", o Tamkeen foi uma iniciativa centrada na construção de capacidades e no aprendizado. Sobretudo, voltou-se ao "amplo treinamento em técnicas de advocacy" (USAID, 2004, p.5), "melhorando a habilidade [de organizações da sociedade civil] de expressar (voice) as necessidades de seus membros (constituents) e de influenciar as políticas (policies) do governo" (USAID, 2004, p.5). De fato, é comum na divulgação do projeto a noção de fortalecimento da "voz" (USAID, 2004, pp. 5; 13; 14) dos palestinos e de suas capacidades de organização, para que eles não apenas compreendam seus direitos e os problemas enfrentados, mas também vocalizem suas posições - isto é, como dito acima, participem de forma mais ativa da construção de políticas e pressão aos órgãos públicos. Outras atividades de construção de competências, menos imediatamente relacionadas ao setor público, também foram financiadas pelo projeto, a maioria através de treinamentos em temas como comunicação, mídia, escrita de aplicações para bolsas de financiamento, gestão financeira e monitoramento de performances (USAID, 2004, pp. 5-6).

Para além do Tamkeen, que atingiu mais de 70 organizações dos TPO (USAID, 2004, p.3), a USAID financiou também, no período entre 2000 e 2002, o "Programa de Construção de Capacidades da Sociedade Civil" (CCSC), cujo objetivo era "o desenvolvimento de capacidade de gestão financeira e governança democrática interna num grupo chave de doze organizações da sociedade civil palestina" (ADF, 2002, p.2 - grifo nosso). Nota-se, aqui, lógica semelhante àquela que governava, no mesmo período, o projeto ONG palestina II: tratava-se de identificar organizações estratégicas, por meio das quais os impactos positivos do financiamento externo poderiam ser espraiados para organizações menores e comunidades menos centrais.

No programa CCSC, mobilizou-se uma abordagem tradicional no campo da saúde pública e da prevenção de doenças: o método Conhecimento-Atitudes-Prática (CAP). O CAP 
consiste em difundir, numa população, certos conhecimentos sobre um comportamento desejado, mas pouco adotado. Busca-se incentivar, por meio do conhecimento adquirido, uma mudança de atitude entre os participantes, para que estes se tornem mais inclinados a incorporar o novo comportamento. Por fim, o componente "prática" da abordagem expressa precisamente essa incorporação da nova conduta na prática cotidiana dos participantes, agora apropriados das informações necessárias para a mudança pretendida (ADF, 2002, p. 2). Através do método CAP, assim, o programa da USAID buscou efetivamente transformar as condutas e estruturas internas de doze organizações palestinas dos TPO - sintonizando-as, assim como fez o Banco Mundial, com as melhores práticas internacionais em matéria de governança democrática e gestão financeira. Tanto no método deste programa, quanto na noção de "empoderamento" do Tamkeen, percebe-se a concepção centrada em transformar os indivíduos e comportamentos (individuais e coletivos), com pouca ou nenhuma ênfase dada às estruturas por trás das condições individuais e coletivas que precisam ser transformadas.

Tanto o Banco Mundial quanto a USAID continuaram, nos anos seguintes, a financiar projetos voltados ao desenvolvimento da "sociedade civil palestina". Uma análise exaustiva dessa intervenção contínua, no entanto, foge ao recorte temporal dessa pesquisa. As características presentes em ambas as fases do "ONG palestina", bem como as alterações realizadas entre uma e outra, expressam algumas das mudanças que a comunidade de assistência externa incentivou nas organizações palestinas, a partir do início dos "processos de paz". Igualmente, as iniciativas da USAID (e, embora em menor grau, também as do Banco Mundial) refletem a concepção de "sociedade civil" incentivada nos TPO - uma concepção que, como será aprofundado a seguir, está em sintonia com o paradigma neoliberal predominante desde os anos 1990. A próxima seção analisa, de forma crítica, como os projetos expostos selecionaram um certo tipo de organização palestina, priorizando um certo modelo de atuação social em detrimento de outros. Em seguida, a conclusão do capítulo busca enfatizar as consequências de tal seleção/exclusão para uma sociedade submetida a uma ocupação militar e a um projeto colonial em andamento.

\subsection{A transformação na sociedade palestina}

A partir da exposição dos projetos do Banco Mundial realizada acima, podem ser destacados alguns eixos de transformação impulsionados pelo financiamento externo nas organizações palestinas da Cisjordânia e da Faixa de Gaza, a partir dos anos 1990. O primeiro eixo de mudança, expresso tanto no "ONG palestina" quanto nos projetos financiados pela 
USAID no mesmo período, é a profissionalização das organizações não-governamentais dos TPO e, consequentemente, de suas formas de associação de maneira mais ampla. Como resultado do desenho do projeto do Banco Mundial e dos critérios nele estabelecidos, acessaram as bolsas organizações com "capacidades" suficientes para passar num processo seletivo competitivo e com familiaridade diante de padrões internacionais de licitação, contabilidade, transparência e gestão financeira. Além disso, como visto, as organizações beneficiadas precisavam conseguir levantar, junto de suas comunidades, valores significativos para contribuir com o programa. Essa estava longe de ser a realidade de organizações de base de vilas palestinas, ou mesmo daquelas atuantes em cidades menores da Cisjordânia e da Faixa de Gaza. Na segunda fase do projeto do Banco, o acesso abrangido a organizações mais locais, por meio do estabelecimento de consórcios, como visto ocorreu através da inserção de organizações menores e mais locais em projetos muito mais amplos que elas, através do estabelecimento de relações hierárquicas com ONGs maiores e centrais. Sendo parte central destes projetos instilar nas associações menores as práticas vistas como adequadas, pode-se dizer que a forte ênfase da segunda fase na "construção de capacidades" expressa, justamente, o ímpeto crescente por profissionalizar a atuação das organizações palestinas.

A profissionalização não pode ser separada de uma transformação associada, de despolitização das organizações palestinas e suas atividades. Como visto, financiadores como o Banco e a USAID impulsionaram nos territórios ocupados, por meio de seus critérios seletivos, uma visão marcadamente técnica de sociedade civil, concebendo-a como politicamente neutra (ALASHQAR, 2018; DANA, 2015; NAKHLEH, 2012, p.132) e como uma aliada necessária no processo de desenvolvimento, este também concebido como tecnicamente objetivo (VELTMEYER, 2008). Fortaleceram-se, assim, ONGs alinhadas a essa concepção. O financiamento de grandes ONGs de advocacy - em detrimento de outras organizações como sindicatos, organizações e cooperativas profissionais, instituições estudantis - enfraqueceu o espírito mais voluntarista que animava as organizações palestinas nos anos 1970 e 1980 (CHALLAND, 2005; NAKHLEH, 2012). Reforça-se dessa forma, com a crescente dependência da assistência financeira externa, um processo de "profissionalização da política" (HAMMAMI, 1995) na sociedade palestina. A emergência da advocacy, tão presente nos programas da USAID, é aqui um bom exemplo: a atividade é concebida como técnica, como prática profissional objetiva que, se amplamente difundida, levaria à formulação de políticas (policies) ótimas, isto é, perfeitamente informadas sobre os problemas enfrentados pela sociedade e, assim, perfeitamente responsivas às "vozes" vindas dela. 
Também relacionado à profissionalização e despolitização da atuação social dos palestinos dos TPO está um outro eixo de mudança estrutural da sociedade palestina: a centralização impulsionada pelo financiamento externo a partir dos anos 1990. Como discutido acima, para além do rigor do processo seletivo presente desde a primeira etapa do projeto do Banco Mundial, a segunda fase aprofundou o foco nas grandes ONGs (como visto, entre 5 e 8 , num universo de centenas), geralmente atuantes nos centros urbanos de Ramallah, Belém e (antes do bloqueio) Gaza. As bolsas de parceria, implementadas na segunda fase do projeto, tornaram-nas líderes de redes locais de associações, repondo uma hierarquia que o próprio Banco Mundial reconhece entre organizações rurais e urbanas. O fato de que as bolsas de desenvolvimento foram fechadas para novas ONGs, em 2001, reflete também a centralização que o financiamento externo incentivou no setor de ONGs dos TPO. Da mesma forma, a criação, pela USAID, de um programa de construção de capacidades da sociedade civil voltado unicamente a poucas organizações-chave também demonstra a tendência de centralização aqui apontada.

A assistência financeira externa à sociedade palestina foi, assim, direcionada sobretudo a ONGs grandes e centralizadas, e os fundos foram, em grande medida, canalizados para projetos de curto ou médio prazo, voltados principalmente à provisão imediata de serviços e à capacitação técnica de setores sociais (CHALLAND, 2005). Como consequência da centralização resultante, há ainda uma mudança significativa no controle sobre a agenda das organizações: se antes de Oslo a atuação se dava sobretudo a partir de comunidades de base, com a construção das agendas de ação ocorrendo no nível local, a condicionalidade imposta por atores como o Banco Mundial e a USAID sobre o financiamento à "sociedade civil palestina" fez com que a agenda das organizações dos TPO passasse a ser profundamente influenciada pelas prioridades dos doadores internacionais (DANA, 2015). Como ficou evidente nos documentos analisados, ainda que financiadores como o Banco não determinassem completamente a agenda das ONGs beneficiadas, os critérios para concessão de bolsas estabelecem um universo bastante restrito de posições aceitas e associações aptas ao financiamento externo. Consolida-se, assim, uma "confluência" entre ONGs palestinas criadas no contexto dos "processos de paz" e os financiadores internacionais (NAKHLEH, 2012, p.133). A agenda (política) prioritária deixa de ser determinada diretamente pelas populações das vilas palestinas, por exemplo - e parece difícil que algumas reuniões públicas, como proposto pelo Banco nos "processos consultivos" dos projetos financiados, fossem suficientes para que as comunidades afetadas tivessem, de fato, controle sobre as agendas implementadas. 
A centralização, portanto, expressou-se não somente pela criação e consolidação de hierarquias entre setores internos da sociedade palestina, mas também pelo deslocamento da definição de agenda para longe das bases - o que significou, necessariamente, uma transformação no próprio conteúdo substantivo da agenda de ação das ONGs palestinas (CHALLAND, 2005). Nesse sentido, Jalali (2013) analisa a frequente mudança no controle sobre a agenda de movimentos sociais locais, quando estes passam a ser fortemente financiados por atores externos. Segundo a autora, é comum que tais movimentos progressivamente deixem de apostar na construção de mobilizações massivas, como estratégia central para atingir seus objetivos. A explicação está no fato de que o financiamento externo torna o contato constante com a base muito menos relevante - quando não completamente desnecessário -, fortalecendo assim organizações sem capacidade de mobilização real da população para o confronto político e para a contestação de estruturas de dominação. Reforça-se assim, novamente, o efeito de despolitização citado acima.

Como resultado dessas transformações, portanto, consolidou-se ao longo dos últimos trinta anos, de forma vinculada aos “processos de paz", um grupo de ONGs palestinas altamente especializadas, embora muito mais distantes das comunidades locais do que as organizações de algumas décadas antes. A transformação no conteúdo da agenda dessas organizações se expressou, como visto, por uma ênfase renovada em atividades de advocacy, conscientização, empoderamento e produção de pesquisas (NAKHLEH, 2012, p. 133). A premissa por trás da abordagem predominante é fortalecer grupos (sobretudo marginalizados) da "sociedade civil palestina", para que eles se tornem capazes de influenciar, por si mesmos, a formulação de política (policy) e tomada de decisão de suas autoridades, tornando-se capazes de lutar pela realização de seus direitos (USAID, 2004).

As mudanças setoriais gerais, avançadas para o "setor de ONGs" ou para a "sociedade civil palestina" dos TPO são, também, um importante eixo de transformação a ser destacado. Como afirmado, instituições como o Banco Mundial e a USAID passaram a mobilizar, nos anos 1990 e 2000, uma concepção de sociedade civil que a afirma como aliada do Estado na gestão de problemas de interesse público (VELTMEYER, 2008; ALASHQAR, 2018). No contexto dos TPO, na década de 1990, isso significava cooperação expandida com a Autoridade Palestina, tão enfatizada em ambas as fases do projeto do Banco. Sendo a própria ANP fruto direto dos "processos de paz", a busca por vincular a "sociedade civil dos territórios" à nova autoridade, numa relação permanente de diálogo e cooperação, representa um mecanismo de enraizamento do enquadramento dos "processos de paz" na sociedade palestina da Cisjordânia 
e da Faixa de Gaza. São financiadas organizações que não fujam das diretrizes predominantes da "paz" e dos dois Estados (CHALLAND, 2005), passando pela aceitação do Estado de Israel e, não raro, pela cooperação direta entre ocupante e ocupado. Associações que não trabalhassem diretamente com a nova autoridade não soberana, e cujas posições não se alinhassem aos "processos de paz" foram, assim, taxadas de "políticas" e marginalizadas pelos critérios de financiamento (DANA, 2015), ao passo que o próprio caráter incontornavelmente político do "setor público" palestino em construção foi de alguma forma escondido, retratado como técnico - lócus de produção da policy objetiva e alvo da boa governança. A abordagem do empoderamento para advocacy, do treinamento para o lobby e da busca por influenciar a formulação local de política pelos órgãos da ANP - presente tanto nos projetos do Banco Mundial quando da USAID - são assim reflexos desse fortalecimento do enquadramento estabelecido em Oslo. A canalização da atuação social dos indivíduos é direcionada para o engajamento com as estruturas estabelecidas do poder político: é por dentro do sistema estabelecido pela Autoridade Nacional Palestina que as organizações palestinas devem buscar influenciar a realidade dos TPO. Associações que denunciem esse sistema, ou busquem atuar por fora dele, foram sistematicamente secundarizadas pelo financiamento internacional (DANA, 2015).

Por fim, uma consequência marcante dessa transformação estrutural da sociedade palestina dos territórios ocupados, que pode ser observada ao longo das últimas três décadas, é a emergência de uma nova elite urbana palestina e de novas "bolhas" urbanas de normalidade na Cisjordânia ocupada. Desde o início dos "processos de paz", cidades como Ramallah e Belém tornaram-se centros de atuação das novas ONGs, bem como de uma nova elite política surgida com as estruturas criadas por Oslo - em grande medida, empregada da ANP e de organizações internacionais. Nas ruas desses centros urbanos, multiplicaram-se shoppings, restaurantes, cafés e hotéis, e a realidade da ocupação israelense parece desaparecer de vista. Os privilégios das maiores ONGs, discutidos nesse capítulo, podem ser indicados como uma importante causa do surgimento desse novo setor social nos territórios palestinos. Empregados dessas organizações e habitantes das "bolhas" urbanas, trata-se de uma classe média internacionalizada, que busca afirmar sua modernidade e sua filiação ao (neo)liberalismo internacional - tanto em termos políticos quanto econômicos (ABOURAHME, 2009; CHALLAND, 2005; TARAKI, 2008). Num contexto em que os financiadores externos apoiam ONGs que não tomem posições políticas explícitas, para além daquelas presentes no enquadramento de Oslo (DANA, 2015), a nova classe média palestina e as ONGs que ela em 
geral compõe passam a entender sua participação no processo político como marcadamente limitada. Compreendem seu papel social como sendo de prover serviços à população, auxiliando à ANP; ou trabalhar dentro do enquadramento das negociações de Oslo, por exemplo através de advocacy perante a autoridade e promoção de boa governança em suas estruturas. O processo político, que supostamente levaria à libertação nacional, é dessa forma compreendido como separado do processo de desenvolvimento socioeconômico e institucional, embora seja beneficiado por ele. A despolitização da sociedade palestina, sugerida acima, reflete-se assim na emergência de um setor social cujo horizonte de atuação nega a busca por libertar a sociedade palestina da ocupação colonial, substituindo a luta anticolonial radical pelo engajamento nas estruturas neoliberais de poder estabelecidas, num arranjo sem soberania palestina.

\subsection{Conclusão: a sociedade palestina e a luta anticolonial}

Independentemente da avaliação em torno do conceito de sociedade civil, associações comumente englobadas pelo termo foram centrais, ao longo da segunda metade do século XX e em diferentes lugares do mundo, por processos de resistência política a projetos coloniais e autoritários. Em lutas de libertação nacional, assim como na derrubada de ditaduras militares, associações de trabalhadores, de juventude, de mulheres, religiosas, entre tantas outras, cumpriram importante papel na organização local das populações em torno de objetivos políticos de emancipação (ALASHQAR, 2018; EDWARDS; FOLEY, 1996). Nas cidades e vilas palestinas da Cisjordânia e da Faixa de Gaza, essa participação ativa das organizações locais na luta nacional foi inegável nas décadas que se seguiram à ocupação israelense (CHALLAND, 2009; DANA, 2015). A Primeira Intifada palestina foi a grande expressão dessa potência política radical: durante os anos do levante, a sociedade civil palestina dos territórios foi incansável em sua luta contra a ocupação colonial sionista, buscou a todo momento se organizar, se fortalecer, se auto sustentar. A organização para garantir sobrevivência material era, antes de mais nada, uma luta política, anticolonial, por libertação: um dos principais lemas dos palestinos sob ocupação era, e continua sendo, "existir é resistir".

Este cenário de alta mobilização política se transformou, e foi o objetivo deste capítulo analisar um, entre os muitos vetores responsáveis por essa transformação: a assistência financeira internacional. Como discutido anteriormente, a neoliberalização nunca foi um projeto de transformação exclusivamente econômica, embora também seja centralmente isso. Parte fundamental do neoliberalismo está em sua busca por intervir na sociedade, transformando-a e, assim, transformando os indivíduos. O projeto neoliberal de "engenharia 
sociopolítica" (HARRISON, 2004, p.22) não pode se esgotar no Estado ou no mercado, tendo também a sociedade como alvo fundamental de intervenção: ele é um projeto voltado, também, à "construção de um modelo de sociabilidade no qual a resistência à política de desenvolvimento neoliberal parece muito mais impensável” (HARRISON, 2010, p.56). Na Cisjordânia e na Faixa de Gaza, as transformações nas organizações palestinas impulsionadas por atores como o Banco Mundial e a USAID, a partir dos anos 1990, refletem essa natureza holística da neoliberalização: não bastava reestruturar a economia dos territórios e construir um "setor público" em sintonia com as diretrizes de internacionalização, privatização e financeirização, era também necessário transformar as características e práticas da própria sociedade palestina dos TPO.

Assim como nos processos de liberalização comercial, financeirização, privatização e estabelecimento da Autoridade Nacional Palestina, a condicionalidade dos financiadores internacionais foi um instrumento central também na transformação da sociedade palestina em chave neoliberal. $\mathrm{O}$ financiamento exclusivo a um modelo de organização não governamental incentivou, entre as populações palestinas dos TPO, um tipo específico de prática associativa como visto, um modelo profissionalizado, especializado, técnico e engajado no mercado e nas estruturas públicas de poder estabelecidas (em acordo com a força ocupante). Formas alternativas de organização social foram secundarizadas, e a potência política da sociedade palestina dos territórios foi progressivamente canalizada para dentro de um novo regime, que não contesta radicalmente a estrutura de dominação colonial de Israel. O projeto neoliberal realiza dessa forma uma de suas operações típicas, destacada na seção anterior: a despolitização; a subsunção das dimensões eminentemente políticas da vida social a esferas privadas, quando não explicitamente econômicas. O resultado dessa "transformação estrutural” (DANA, 2015) na sociedade dos TPO, ao longo dos últimos trinta anos, não pode ser outro que o enfraquecimento dessa sociedade numa luta que é inerentemente política. Se a realidade dos territórios é analisada de uma perspectiva que compreende a ocupação como um projeto colonial de povoamento (DANA; JARBAWI, 2017; WOLFE, 2016), e que reconhece nas práticas de associação da sociedade palestina um lócus potencial de luta e resistência anticolonial (ALASHQAR, 2018; DANA, 2015; NAKHLEH, 2012), então as transformações impulsionadas desde o início dos "processos de paz" pelos financiadores externos não representam mais que um reforço às práticas coloniais de Israel (TURNER, 2012), na medida em que minam as condições políticas, sociais e econômicas da sociedade palestina dos TPO de resistir a tais práticas. 


\section{CONSIDERAÇÕES FINAIS}

O objetivo dos capítulos anteriores foi explicitar e analisar uma concepção e uma prática de desenvolvimento socioeconômico e político-institucional, impulsionadas nos territórios da Cisjordânia e da Faixa de Gaza por uma comunidade de financiadores internacionais, em larga medida ocidental e liderada por instituições como o Banco Mundial. Após quase trinta anos de intensa participação dessa comunidade em projetos de desenvolvimento nos territórios palestinos ocupados, o cenário destes e da sociedade palestina que neles vive transformaram-se profundamente. Como abordado no primeiro capítulo, em paralelo aos "processos de paz" aplicou-se, por meio do financiamento externo, um modelo de desenvolvimento característico do neoliberalismo. Na dimensão econômica, os processos de financeirização, privatização e liberalização comercial levaram ao surgimento de "bolhas de crescimento econômico" em cidades como Ramallah, onde bairros de classe média alta, um centro moderno e internacionalizado, com grandes prédios, centros de compras, avenidas e marcas conhecidas fazem sumir da vista imediata as forças da ocupação militar e do assentamento colonial. Um outro exemplo marcante do modelo de desenvolvimento impulsionado ao longo das últimas três décadas pode ser encontrado não muito longe de Ramallah, na cidade projetada de Rawabi. Financiada pelo grande setor privado palestino - por um membro da família al-Masri, que controla a $\mathrm{PADICO}^{104}$-, a cidade representa uma alternativa para a nova classe média (alta) palestina, que emergiu como fruto das transformações ocorridas desde os "processos de paz". Basta se mover algumas dezenas de quilômetros desses centros urbanos para notar, contudo, que as forças da ocupação continuam tão presentes quanto sempre estiveram - se não mais - e que os assentamentos israelenses se proliferam.

No que diz respeito ao objetivo de construção da Autoridade Nacional Palestina, a comunidade doadora internacional buscou implementar um modelo de "boa governança". Foi peculiar do caso palestino que o processo de neoliberalização tenha acontecido em paralelo à própria construção das estruturas “estatais" e, principalmente, que tais estruturas não estivessem sendo construídas para possuírem soberania de fato. Mesmo nesse cenário, como visto, o Banco Mundial e o FMI prescreveram diretrizes estritamente neoliberais à ANP, o que se aprofundou ainda mais a partir dos anos 2000. Num processo que se iniciou logo após sua criação rapidamente defendendo privatizações e uma economia voltada para exportação, fortemente

\footnotetext{
104 <https://www.cbsnews.com/news/inside-rawabi-a-new-west-bank-city-built-by-bashar-masri-for-palestinians60-minutes-2019-12-08/>. Acesso em: 15.07.2020.
} 
baseada no setor privado - a autoridade foi progressivamente se sintonizando à visão neoliberal de gestão pública (HADDAD, 2016; KHALIDI; SAMOUR, 2011; LEECH, 2012).

Consolidou-se assim, como um dos muitos efeitos impostos pelos novos enquadramentos dos "processos de paz", a construção de um proto-Estado neoliberal nos TPO, através da internalização pela ANP dos padrões internacionais de gestão financeira neoliberal de ajuste constante - e de "boa governança". O ápice deste ímpeto neoliberalizante se daria a partir da segunda metade dos anos 2000, após a Segunda Intifada e a separação entre Cisjordânia e Faixa de Gaza. A partir dos anos 2000, a autoridade passaria a realizar progressivos ajustes e reformas administrativas, buscando sintonizar-se com as "melhores práticas" internacionais. A reforma, a partir deste período, se tornou uma das preocupações centrais dos planos de desenvolvimento lançados pela ANP.

Como discutido anteriormente, a fase mais acabada desse proto-Estado neoliberal palestino, nos anos 2000, se deu com o Fayyadismo. Vários planos de desenvolvimento foram elaborados pela ANP desde então - em parceria com financiadores externos -, aperfeiçoando as práticas da autoridade e suas relações com o setor privado e a "sociedade civil palestina": o Plano de Reforma e Desenvolvimento Palestino (2008), elaborado sob os auspícios de Salam Fayyad; seu programa de governo como primeiro ministro, intitulado "Palestina: Acabando com a Ocupação, Estabelecendo o Estado" (2009); e o documento para o segundo ano do mesmo governo, que levou o nome de "Reta Final para Liberdade" (2010) (LEECH, 2012, p.2). Os projetos expressam a internalização do ethos neoliberal pela autoridade, marcando o enquadramento da mesma nos padrões internacionais de governança (KHALIDI; SAMOUR, 2011). Os resultados dessa incorporação neoliberal, dessa adoção do neoliberalismo como estratégia da ANP para a libertação nacional, ficam evidentes ao contrastar a realidade palestina atual com os próprios nomes escolhidos para os programas: mais de uma década depois, a ocupação nunca esteve mais distante de acabar, e não há qualquer horizonte de estabelecimento de um Estado soberano palestino. A liberdade da sociedade palestina dos TPO, assim, continua tão bloqueada quanto em 1967, se não mais, e a reta final de Fayyad pode plausivelmente se estender por mais várias décadas.

A ANP emerge assim, no final da primeira década deste século, como mais um exemplo de construção, pelo Banco Mundial (mas não somente por ele), do que Graham Harrison (2004) identifica como "Estados Governança". Construídos quase do zero pela intervenção das instituições financeiras e agências doadoras internacionais, têm suas estruturas e práticas inteiramente moldadas pela lógica neoliberal de priorização do mercado e tecnicização da 
política. Esse movimento de internalização de práticas neoliberais pelas estruturas estatais, observado nos TPO, tem sido em realidade um dos efeitos frequentes da atuação do Banco Mundial em outras regiões, como o continente africano (HARRISON, 2004; 2010). Os planos de desenvolvimento lançados pelos governos da autoridade palestina, ao longo dos anos 2000 e 2010, apenas demonstram que esse processo de internalização se completou, e a ANP é hoje um modelo de Estado neoliberal (DARDOT; LAVAL, 2016; HARVEY, 2008), com o único problema de não possuir soberania alguma, continuando sob controle de um Estado cujas intenções coloniais de povoamento sobre os TPO são evidentes. Concluiu-se, dessa forma, uma longa trajetória de transformação da liderança do movimento de libertação nacional (KHALIDI, Raja, 2018), que se tornou, em grande medida, um gestor proto-estatal da vida palestina sob ocupação em áreas A e B, isto é, em pequenas parcelas de território desconectadas umas das outras (KHALIDI; SAMOUR, 2011).

Para além da transformação da economia dos territórios e da liderança política do movimento de libertação nacional palestino, o terceiro capítulo dessa dissertação buscou demonstrar uma outra dimensão, igualmente fundamental, da neoliberalização dos territórios palestinos impulsionada pela comunidade de assistência externa. Não foi somente a liderança da OLP que se tornou "menos radical" e se adequou aos padrões internacionais de gestão da coisa pública: a própria sociedade palestina foi transformada, segundo linhas típicas do modelo neoliberal de concepção da "sociedade civil". As atividades de organizações palestinas, como visto, foram significativamente remodeladas, canalizando-se com frequência para uma atuação institucional e profissionalizada perante a ANP e outras estruturas internacionais, como a ONU. O objetivo foi enraizar a boa governança, fortalecer as associações da sociedade como parceiras do "Estado" e responsáveis por exigir dele níveis satisfatórios de transparência e accountability. Como resultado, a sociedade palestina dos TPO nunca foi tão especializada em advocacy e gestão de projetos - de fato, uma especialização muito mais expressiva que os níveis locais de mobilização política.

\section{Que desenvolvimento?}

A introdução de um modelo neoliberal de desenvolvimento, a partir dos anos 1990, trouxe assim grandes impactos não apenas à economia, mas à política e à sociedade palestinas dos TPO. Mas sobre quais critérios se basear, para propor um modelo de desenvolvimento alternativo para a sociedade palestina sob ocupação? Que tipo de desenvolvimento é sistematicamente bloqueado pela ocupação colonial e pela dependência palestina em relação à assistência externa financeira? Se o desenvolvimento é a transformação estrutural da sociedade 
em direção a objetivos socialmente comuns (ROY, 1999, pp.64-65), qual é a natureza qualitativa da transformação estrutural necessária à sociedade palestina dos territórios, e impedida pela condição de des-desenvolvimento na qual se encontra essa sociedade?

Cumpre, aqui, unir a noção de des-desenvolvimento de Sara Roy com alguns outros conceitos, forjados da reestruturação crítica da ideia de desenvolvimento, quando aplicada à situação de contínua submissão colonial palestina. Khalil Nakhleh (2012, pp.xvii-xix), por exemplo, propõe a ideia de um desenvolvimento libertador centrado nas pessoas (DLCP), visando expandir as compreensões predominantes sobre desenvolvimento socioeconômico e ultrapassar as estreitas barreiras de concepções como a que passou a ser implementada no caso das zonas industriais. Para Nakhleh, em sintonia com Roy, o desenvolvimento é mais amplo que crescimento econômico e expansão da renda em uma economia. Ele possui dimensões eminentemente sociais e políticas. Um desenvolvimento libertador e centrado nas pessoas

\section{[...] é um processo de intervenção intencional cujo objetivo é ampliar ao máximo as escolhas individuais e coletivas do ser humano, do indivíduo, do cidadão médio, e que é sustentável de uma geração para a próxima (NAKHLEH, 2012, p.xvii).}

O DLCP tem como prioridade o fortalecimento dos recursos e das populações locais. Enfatiza a produção sobre o consumo, visando a autossuficiência e a maximização dos recursos humanos e materiais locais de uma sociedade. Em sentido semelhante, Alaa Tartir (2012, p.12) também sugere um "desenvolvimento centrado nas pessoas", compreendendo-o como "um processo socioeconômico e político complementar cumulativo, para as pessoas e pelas pessoas, que visa expandir as [suas] capacidades e liberdades". Compreendido como processo não apenas econômico, este modelo de desenvolvimento tem como resultado o fortalecimento do tecido social, e seu objetivo crucial é a libertação das pessoas em relação não somente a privações econômicas, mas também em relação a dominações sociais, políticas e coloniais. Um desenvolvimento libertador e centrado nas pessoas, assim, visa impulsionar a resiliência política e econômica de um povo, dando condições para que os indivíduos e as comunidades consigam lutar por seus direitos sociais, políticos e econômicos (NAKHLEH, 2004, 2012; TARTIR, 2012, pp.3-4). Para usar os termos de Tartir (2012, p.7), no que tange à ênfase neoliberal num modelo de desenvolvimento para exportação: "Dados nossos recursos limitados, não deveríamos dar atenção a garantir autossuficiência primeiro, antes de nos voltarmos para exportações, ao menos em termos de produtos básicos? ”.

Outros termos foram mobilizados para pensar um desenvolvimento palestino alternativo, que seja concebido tomando, como ponto de partida, a condição palestina de 
submissão a uma ocupação colonial de povoamento. Tariq Dana (2014, p.1), por exemplo, sugere a noção de "economia de resistência", definida como "uma forma de luta econômica que visa uma reorganização transitória da economia e das relações sociais, para que estejam em harmonia com os requisitos e objetivos políticos do processo de libertação nacional palestino". Assim, trata-se de uma estratégia política de desenvolvimento econômico ${ }^{105}$. Em chave semelhante - e em diálogo direto com Dana (2014) -, Timothy Seidel (2019, p.727) propõe o conceito de "economias políticas de resistência", enfatizando em particular a necessidade de fundar, na sociedade palestina dos TPO, uma nova consciência e prática da luta nacional, que não se restrinja às trajetórias impostas pelo limitado nacionalismo palestino encarnado nas negociações de Oslo.

Um exemplo concreto de como operacionalizar um modelo alternativo para o desenvolvimento local palestino, diante da continuidade da ocupação colonial israelense, é o estabelecimento de cooperativas agrícolas organizadas a partir da base e controladas pela base. Trata-se, em outros termos, de propor cooperativas capazes de articular as competências e atender às demandas locais, em termos de produção e consumo de produtos agrícolas. A ênfase, aqui, é na geração de empregos a partir do pequeno agricultor palestino, da agricultura de baixa intensidade, tendo como objetivo antes a segurança e soberania alimentar palestina - a substituição do consumo de produtos israelenses ou obtidos por financiamento externo -, mais do que a busca por acessar mercados internacionais (ABDELNOUR; TARTIR; ZURAYK, 2012; DANA, 2014; SEIDEL, 2019; ZEIN, 2017).

Tal modelo se opõe às cooperativas comumente financiadas pela comunidade externa, focadas em agricultura intensiva de larga escala e produção para exportação. Por exemplo, é comum que o financiamento externo incentive o estabelecimento de amplas plantações de tâmaras, no Vale do Jordão, em detrimento das tradicionais plantações de oliveiras, cujas necessidades em termos de irrigação são marcadamente menores. $O$ pequeno agricultor palestino, assim, com frequência se vê impossibilitado de arcar com os custos e a logística necessários para atender às demandas dos financiadores, e muitas vezes não veem alternativa que não abandonar seus cultivos. Na ausência de capacidade suficiente para a irrigação dos modelos de plantação financiados, o produtor local torna-se, progressivamente, empregado de uma elite palestina financiada externamente, que consegue produzir em escala e que mantém,

\footnotetext{
${ }^{105}$ Dana (2014, pp.3-4) analisa a experiência do Movimento dos Trabalhadores Rurais sem Terra (MST) do Brasil como um exemplo de economia de resistência organizada em oposição a uma estrutura econômica neoliberal.
} 
como visto no segundo capítulo, relações de cooperação com o setor privado israelense e com as autoridades da ocupação (SEIDEL, 2019, p. 737).

Evidentemente, uma perspectiva de desenvolvimento centrada na soberania alimentar para resiliência política não será plenamente atingida antes da completa soberania palestina sobre a terra ser obtida. Contudo, tal perspectiva visa, justamente, fortalecer a população palestina em sua luta por soberania, garantindo maiores níveis de segurança alimentar e, como consequência, menor dependência em relação às forças da ocupação, à economia israelense e à assistência externa. Michael Foley (2019), em seu livro "Cultivando para o Longo Prazo: Resiliência e a Arte Perdida da Inventividade Agrícola"106, aborda a relação entre a agricultura de pequena escala e a resiliência social, política e econômica de uma população. Foley critica a lógica de lucro que sustenta plantações intensivas e de larga escala, reduzindo a atividade agrícola a uma produção puramente econômica (e capitalista) e desconectando-a de suas dimensões sociais e políticas - de suas conexões com a comunidade local, de suas dimensões não redutíveis à mensuração monetária. $\mathrm{O}$ autor aponta que sistemas agrícolas bem-sucedidos, ao longo da história, frequentemente tiveram como foco prioritário a auto sustentabilidade, sendo a venda para lucros em mercados externos um objetivo secundário, embora nem sempre completamente descartado. O pequeno fazendeiro, para Foley (2019), é um pesquisador, um inventor e deve ser um agente de sua comunidade - não apenas garantindo o consumo local, mas difundindo novos conhecimentos e técnicas; agindo não como um produtor de lucros, mas como um garante da resiliência social local, nos momentos de maior dificuldade.

As ideias de Foley, embora não tenham sido concebidas para um contexto como o dos TPO, reverberam na realidade palestina sob ocupação. Contra as pressões neoliberalizantes internacionais, bem como contra o avanço colonial israelense, o pequeno agricultor palestino deve ser compreendido como um potencial de resiliência e resistência. Contudo, a pequena agricultura familiar, existente em larga escala nos TPO, não é importante unicamente por sua capacidade de alimentar as populações locais e combater a dependência econômica - e alimentar - palestina em relação a Israel. O pequeno agricultor palestino é fundamental também em sua importância simbólica, identitária e cultural: ele representa a conexão com a terra, a produção a partir da terra. Em outros termos, ele representa a permanência palestina na terra ocupada e colonizada. Se o colonialismo de povoamento sionista tem na terra palestina seu principal alvo; se seu objetivo último é esvaziar a terra para reocupa-la com judeus israelenses,

${ }^{106}$ No original, "Farming for the Long Haul: Resilience and the Lost Art of Agricultural Inventiveness". 
transformando sua demografia; então a necessidade de fortalecimento da sociedade palestina contra esse projeto colonial passa, de forma central, por reforçar a todo momento a conexão do palestino com sua terra (ABDELNOUR; TARTIR; ZURAYK, 2012; DANA, 2017; SEIDEL, 2019). Se a condição (econômica, mas também social e política) palestina é resultado de uma estrutura de dominação colonial, qualquer desenvolvimento socioeconômico - concebido como resistência política - na Palestina ocupada precisa ter como um objetivo prioritário garantir, aos setores mais vulneráveis da população, a capacidade de continuar na terra, vivendo e produzindo, existindo e resistindo. 


\section{REFERÊNCIAS BIBLIOGRÁFICAS}

ABDELNOUR, Samer; TARTIR, Alaa; ZURAYK, Rami. Farming Palestine for Freedom. AlShabaka Policy Brief, Washington, D.C.: 2012.

ABDO, Nahla. Imperialism, the State, and NGOs: Middle Eastern Contexts and Contestations. Comparative Studies of South Asia, Africa and the Middle East, v. 30, n. 2, 238-249, 2010. ABOURAHME, Nasser. The Bantustan Sublime: Reframing the Colonial in Ramallah. City, v.13, n.4, 499-509, 2009.

ADVANI, Rohan. Pockets of Privilege: A Historical, Spatial, and Political Economy Analysis of Industrial Zones in Palestine. New Middle Eastern Studies, v. 7, 1-30, 2017.

Pockets of Privilege: A Historical, Spatial and Political Economy Analysis of Industrial Zones in Palestine. Thesis: Georgetown University, 2016.

ALASHQAR, Yaser. The Politics of Social Structures in the Palestinian Case: from National Resistance to Depoliticization and Liberation. Social Sciences, v. 7, n. 69, 2018.

AMERICA'S DEVELOPMENT FOUNDATION (ADF). Civil Society Capacity Building Program West Bank and Gaza Strip: Final Report. Alexandria: out., 2002.

BABB, Sarah. Beyond the Development Banks: Washington Politics, World Poverty and the Wealth of Nations. Chicago: University of Chicago Press, 2013.

The Washington Consensus as Transnational Policy Paradigm: Its Origins, Trajectory and Likely Successor. Review of International Political Economy, v. 20, n. 2, 268-297, 2012. BANCO MUNDIAL. Governance and Development. Washington, DC: 1992.

Developing the Occupied Territories: an Investment in Peace, Volume I: Overview. Washington, D.C.: set., 1993a.

Developing the Occupied Territories: an Investment in Peace, Volume II: The Economy. Washington, D.C.: set., 1993 b.

Developing the Occupied Territories: an Investment in Peace, Volume III: Private Sector Development. Washington, D.C.: set., 1993c.

Developing the Occupied Territories: an Investment in Peace, Volume IV: Agriculture. Washington, D.C.: set., 1993d.

Developing the Occupied Territories: an Investment in Peace, Volume V: Infrastructure. Washington, D.C.: set., 1993e.

Developing the Occupied Territories: an Investment in Peace, Volume VI: Human Resources and Social Policy. Washington, D.C.: set., $1993 f$. 
. Emergency Assistance Program for the Occupied Territories. Washington, D.C.: 1994c.

Emergency Assistance to the Occupied Territories: Volume I: Investment Program. Washington, D.C.: mar., 1994a.

. Emergency Assistance to the Occupied Territories: Volume II: Technical Assistance Program. Washington, D.C.: mar., 1994b.

Implementation Completion Report: Gaza Industrial Estate. 2005.

. Project Appraisal Document for a Proposed Trust Fund Credit for the Gaza Industrial Estate Project. Washington, D.C.: dez., 1997b.

Project Appraisal Document on a Proposed Grant in the Amount of US\$8 Million to the Welfare Association - West Bank and Gaza for the Palestinian NGO Project (II). Washington, D.C.: mai., 2001.

Project Appraisal Document on a Proposed Trust Fund Grant in an Amount of US\$10 Million to West Bank and Gaza for the Palestinian NGO Project. Washington, D.C.: jun., 1997a.

; UNITED NATIONS OFFICE OF THE SPECIAL COORDINATOR IN THE OCCUPIED TERRITORIES (UNSCO). Donor Investment in Palestinian Development 1994-1998. Jerusalém: 1999.

BECKMAN, Björn. The Liberation of Civil Society: Neo-Liberal Ideology and Political Theory. Review of African Political Economy, v.20, n. 58, 20-33, 1993.

BEININ, Joel. Palestine and Israel: Perils of a Neoliberal, Repressive "Paz Americana". Social Justice, v. 25, n. 4, 20-39, 1998.

BOUHABIB, Abdallah. The World Bank and International Aid to Palestine: An Interview with Abdallah Bouhabib. Journal of Palestine Studies, vol. 23, n. 2, 64-74, 1994.

BOUILLON, Markus. Gramsci, Political Economy and the Decline of the Peace Process. Critique: Critical Middle Eastern Studies, v. 13, n. 3, 239-264, 2004.

. The Failure of Big Business: on the Socio-Economic Reality of the Middle East Peace Process. Mediterranean Politics, v. 9, n. 1, 1-28, 2010.

The Peace Business: Money and Power in the Palestine-Israel Conflict. I.B. Tauris: 2004.

BRENNER, Neil; PECK, Jamie; THEODORE, Nik. Variegated Neoliberalization: Geographies, Modalities, Pathways. Global Networks, v. 10, n.2, 182-222, 2010. 
BROWN, Wendy. Undoing the Demos: Neoliberalism's Stealth Revolution. Nova York: Zone Books, 2015.

BRYNEN, Rex. A Very Political Economy: Peacebuilding and Foreign Aid in the West Bank and Gaza. Washington: United States Institute of Peace, 2000.

Buying Peace? A Critical Assessment of International Aid to the West Bank and Gaza. Journal of Palestine Studies, vol. 25, n. 3, 79-92, 1996a.

International Aid to the West Bank and Gaza: A Primer. Journal of Palestine Studies, v. 25, n.2, p. $46-53,1996$ b.

. The neopatrimonial dimension of Palestinian politics. Journal of Palestine Studies, v. 25, n. 1, 23-36, 1995.

BURAWOY, Michael. O estudo de caso ampliado: raça e classe na África pós-colonial. In: Marxismo sociológico: Quatro países, quatro décadas, quatro grandes transformações e uma tradição crítica. São Paulo: Alameda, 2014.

BUSSE, Jan. Theorizing Governance as Globalized Governmentality: The Dynamics of WorldSocietal Order in Palestine. Middle East Critique, v.24, n.2, 161-189, 2015.

CHALLAND, Benoît. Looking Beyond the Pale: International Donors and Civil Society Promotion in Palestine. Palestine-Israel Journal of Politics, Economics and Culture, v.12, n.1, 56-63, 2005.

Palestinian Civil Society: Foreign donors and the power to promote and exclude.

Londres: Routledge, 2009.

The Evolution of Western Aid for Palestinian Civil Society: Bypassing Local Knowledge and Resources. Middle Eastern Studies, v.44, n.2, 397-417, 2008.

CHANDLER, David. International Statebuilding: The rise of post-liberal governance. Londres: Routledge, 2010.

CHOUDRY, Aziz; KAPOOR, Dip. Introduction: NGOization: Complicity, Contradictions and Prospects. In: NGOization: Complicity, Contradictions and Prospects. Londres: Zed Books, 2013.

CLARNO, Andy. Neoliberal Apartheid: Palestine/Israel and South Africa after 1994. Chicago: The University of Chicago Press, 2017.

Neoliberal Colonization in the West Bank. Social Problems, v. 65, 323-341, 2018. COOPER, Neil; TURNER, Mandy; PUGH, Michael. The end of history and the last peacebuilder: a reply to Roland Paris. Review of International Studies, v. 37, 1995-2007, 2011. 
CORNWALL, Andrea; BROCK, Karen. What do buzzwords do for development policy? A critical look at "participation", "empowerment" and "poverty reduction". Third World Quarterly, v. 26, n. 7, 1043-1060, 2005.

DANA, Tariq. A Resistance Economy: What is it and Can it Provide an Alternative? Rosa Luxemburg Stiftung Pal Papers, 1-14, 2014.

Disconnecting Civil Society from its Historical Extension: NGOs and Neoliberalism in Palestine. In: TAKAHASHI, Saul (ed.). Human Rights, Human Security and State Security: The Intersection. Westport: Praeger, 2014.

The Structural Transformation of Palestinian Civil Society: Key Paradigm Shifts. Middle East Critique, v. 24, n. 2, 191-210, 2015 a.

The symbiosis between Palestinian "Fayyadism" and Israeli "Economic Peace": the Political Economy of Capitalist Peace in the Context of Colonisation. Conflict, Security \& Development, v. 15, n. 5, 455-477, 2015b.

; JARBAWI, Ali. A Century of Settler Colonialism in Palestine: Zionism's Entangled Project. Brown Journal of World Affairs, v.24, n. 1, 197-219, 2017.

DARDOT, Pierre; LAVAL, Christian. A Nova Razão do Mundo: Ensaio sobre a Sociedade Neoliberal. São Paulo: Boitempo, 2016.

DUMÉNIL, Gérard; LÉVY, Dominique. A Crise do Neoliberalismo. São Paulo: Boitempo, 2013.

; Neoliberalismo - Neo-imperialismo. Economia e Sociedade, v. 16, n. 1 (29), pp. 1-19, 2007.

; . The Neoliberal (Counter-)Revolution. In: JOHNSTON, D.; SAAD-FILHO, A. (eds.). Neoliberalism: A Critical Reader. Londres: Pluto Press, 2005. EDWARDS, Michael. Civil Society. Cambridge: Polity Press, 2004.

; HULME, David (eds.). Beyond the Magic Bullet: NGO Performance and Accountability in the Post-Cold War World. Boulder: Kumarian Press, 1996.

; __ Making a Difference: NGOs and Development in a Changing World. Abingdon: Routledge, 1992.

; Scaling up NGO Impact on Development: Learning from Experience.

Development in Practice, v.2, n.2, pp.77-91, 1992.

EPSTEIN, Gerald. The Triple Debt Crisis. World Policy Journal, vol. 2, n.4, 625-57, 1985.

FANON, Frantz. Os Condenados da Terra. Rio de Janeiro: Civilização Brasileira, 1968. 
FARSAKH, Leila. Palestinian Economic Development: Paradigm Shifts since the First Intifada. Journal of Palestine Studies, v. 45, n. 2, 55-71, 2016a.

Undermining Democracy in Palestine: the Politics of International Aid since Oslo.

Journal of Palestine Studies, vol. 45, n. 4, 48-63, $2016 \mathrm{~b}$.

FAYYAD, Salam. A Palestinian State in Two Years: interview with Salam Fayyad, Palestinian

Prime Minister. Journal of Palestine Studies, v. 34, n.1, 58-74, 2009.

FERGUSON, James. Global Shadows: Africa in the Neoliberal Order. Durham: Duke University Press, 2006.

The Anti-Politics Machine: "Development", Depoliticization, and Bureaucratic Power in Lesotho. Minneapolis: University of Minnesota Press, 1994.

FISCHER, Stanley. The Israeli Stabilization Program, 1985-86. The American Economic Review, vol. 77, no. 2, 275-278, 1987.

FOLEY, Michael W.; EDWARDS, Bob. Civil Society and Social Capital Beyond Putnam. American Behavioral, v. 42, n. 1, 124-139, 1998.

.; __ The Paradox of Civil Society. Journal of Democracy, v. 7, n. 3, 38-52, 1996.

FOLEY, Michael. Farming for the Long Haul: Resilience and the Lost Art of Agricultural Inventiveness. White River Junction, Vermont: Chelsea Green, 2019.

FOUCAULT, Michel. Le jeu de Michel Foucault. In : Dits et écrits II: (1976-1988). Paris : Gallimard, 2001

Nascimento da Biopolítica. São Paulo: Martins Fontes, 2008.

FRISCH, Hillel; HOFNUNG, Menachem. State Formation and International Aid: The Emergence of the Palestinian Authority. World Development, vol. 25, n. 8, 1243-1255, 1997. FUKUYAMA, Francis. The End of History and the Last Man. Nova York: The Free Press, 1992.

FUKUYAMA, Francis. The End of History? The National Interest, 1989.

GAGO, Verónica. A razão neoliberal: economias barrocas e pragmática popular. São Paulo: Elefante, 2018.

GORDON, Neve. Israel's Occupation. Berkeley: University of California Press, 2008.

GRANDINETTI, Tina. The Palestinian Middle Class in Rawabi; Depoliticizing the Occupation. Alternatives: Global, Local, Political, v. 40, n.1, 63-78, 2015.

HADDAD, Toufic. Palestine Ltd.: Neoliberalism and Nationalism in the Occupied Territory. Londres: I. B. Tauris, 2016 
HAMMAMI, Rena. NGOs: the professionalization of politics. Race and Class, v. 37, n. 2, 5163, 1995.

HANAFI, Sari. ONG palestiniennes et bailleurs de fonds: la formation d'un agenda. In: NÉFISSA, Sarah B; HANAFI, Sari. Pouvoirs et Associations dans le Monde Arabe. Paris: CNRS Éditions, 2002.

HANIEH, Adam. Development as Struggle: Confronting the Reality of Power in Palestine. Journal of Palestine Studies, v.45, n.4, 32-47, 2016.

From State-Led Growth to Globalization: the Evolution of Israeli Capitalism. Journal of Palestine Studies, v. 32, n. 4, 5-21, 2003.

The internationalization of Gulf capital and Palestinian class formation. Capital and Class: v. 35, n.1, 81-106, 2010.

HARRISON, Graham. Neoliberal Africa: the Impact of Global Social Engineering. Londres: Zed Books, 2010.

The World Bank and Africa: The construction of governance states. Londres e Nova York: Routledge, 2004.

The World Bank, Governance and Theories of Political Action in Africa. The British

Journal of Politics and International Relations, v. 7, n. 2, 240-260, 2005.

HARVEY, David. A acumulação via espoliação. In: O Novo Imperialismo. São Paulo: Edições Loyola, 2004.

O Neoliberalismo: história e implicações. São Paulo: Edições Loyola, 2008.

HEVER, Shir. The Political Economy of Israel's Occupation: Repression beyond Exploitation. Londres: Pluto Press, 2010.

HODGKINSON, Virginia A.; FOLEY, Michael W. (eds.). The Civil Society Reader. Líbano, N.H.: University Press of New England, 2003.

HOWELL, Jude. Making Civil Society from the Outside: Challengers for Donors. European Journal of Development Research, v. 12, n. 1, 3-22, 2000.

HUNTINGTON, Samuel. The Clash of Civilizations and the Remaking of World Order. Nova York: Simon \& Schuster, 1996.

JALALI, Rita. Financing Empowerment? How Foreign Aid to Southern NGOs and Social Movements Undermines Grass-Roots Mobilization. Sociology Compass, v. 7, n. 1, 55-73, 2013.

JOHNSTON, Deborah; SAAD-FILHO, Alfredo (eds.). Neoliberalism: A Critical Reader. Londres: Pluto Press, 2005. 
KAPUR, Devesh; LEWIS, John P.; WEBB, Richard. The World Bank: Its First Half Century (Vol. 1). Washington, D.C.: Brookings Institution Press, 1997a.

KAPUR, Devesh; LEWIS, John P.; WEBB, Richard. (eds.). The World Bank: Its First Half Century (Vol. 2: Perspectives). Washington, D.C.: Brookings Institution Press, 1997b.

KHALIDI, Raja. Nation and Class: Generations of Palestinian Liberation. Rethinking Marxism, v.30, n.3, 368-392, 2018. The Economics of Political Survival. Journal of Palestine Studies, v.14, n.4, 153$154,1985$.

; SAMOUR, Sobhi. Neoliberalism as Liberation: the Statehood Program and the Remaking of the Palestinian National Movement. Journal of Palestine Studies, v.40, n.2, 6$25,2011$.

KHALIDI, Rashid. The Iron Cage: The Story of the Palestinian Struggle for Statehood. Boston: Beacon Press, 2006.

KHALIDI, Walid. Remembering Hasib Sabbagh (1920-2010). Journal of Palestine Studies, v.39, n.3, 52-65, 2010.

Revisiting the UNGA Partition Resolution. Journal of Palestine Studies, v.27, n.1, $5-21,1997$.

KHOURY, Nadim. National Narratives and the Oslo Peace Process: How Peacebuilding Paradigms Address Conflicts Over History. Nations and Nationalism, v.22, n.3, 465-483, 2016.

LAGERQUIST, Peter. Privatizing the Occupation: The Political Economy of an Oslo Development Project. Journal of Palestine Studies, v. 32, n. 2, 5-20, 2003.

LEECH, Philip. Re-reading the Myth of Fayyadism: A Critical Analysis of the Palestinian Authority's Reform and State-building Agenda, 2008-2011. Doha: Arab Center for Research and Policy Studies, 2012.

LEUENBERG, Christine; EL-ATRASH, Ahmad. Building a Neoliberal Palestinian State under Closure: The Economic and Spatial Implications of Walls and Barriers. The European Electronic Newsletter, v. 16, n. 2, 21-31, 2015.

LEWIS, David. Civil society in non-Western contexts: reflections on the "usefulness" of a concept. Londres: London School of Economics and Political Sciences: Civil Society Working Paper, n.13, 2001.

Old and New Civil Societies? Reflections on NGOs, State and Democracy in Bangladesh. Journal des Anthropologues, v.94, n.95, pp. 93-121, 2004. 
MASALHA, Nur. The Palestine Nakba: Decolonizing History, Narrating the Subaltern, Reclaiming Memory. Londres: Zed Books, 2012.

MEARI, Lena. Colonial Dispossession, Developmental Discourses, and Humanitarian Solidarity in 'Area C': the case of the Palestinian Yanun Village. Community Development Journal, v. 52, n. 3, 506-523, 2017.

MERZ, Sibille. "Missionaries of the new era": Neoliberalism and NGOs in Palestine. Institute of Race Relations, v. 52, n. 50-66, 2012.

MUSLIH, Muhammad. Palestinian Civil Society. Middle East Journal, v. 47, n. 2, 258-274, 1993.

MUSTAFA, Mohammad. The Palestinian Economy and Future Prospects: interview with Mohammad Mustafa, head of the Palestine Investment Fund. Journal of Palestine Studies, v.34, n.3, 40-51, 2010.

NAKHLEH, Khalil. Globalized Palestine: The National Sell-Out of a Homeland. Trenton: Red Sea Press, 2012.

NAQIB, Fadle. Economic Aspects of the Palestinian-Israeli Conflict: the Collapse of the Oslo Accords. Journal of International Development, v. 15, n. 4, 499-512, 2003.

NATIONAL DEMOCRATIC INSTITUTE FOR INTERNATIONAL AFFAIRS (NDI). Building an Informed and Active Civil Society in the West Bank and Gaza Strip: Final Report. Washington, D.C.: 1999.

NELSON, Paul J. The World Bank and Non-Governmental Organizations: the Limits of Apolitical Development. Londres: Palgrave Macmillan, 1995.

PAPPÉ, Ilan. A History of Modern Palestine. Cambridge: Cambridge University Press, 2006a.

The Ethnic Cleansing of Palestine. Oxford: Oneworld, 2006b.

PARIS, Roland. International Peacebuilding and the 'Mission Civilisatrice'. Review of International Studies, v. 28, n. 4, 637-656, 2002.

Peacebuilding and the Limits of Liberal Internationalism. International Security, v. 22, n. 2, 54-89, 1997.

PARPART, Jane L.; VELTMEYER, Henry. The Development Project in Theory and Practice: A Review of its Shifting Dynamics. Canadian Journal of Development Studies, v. 25, n. 1, 39-59, 2004.

PAYER, Cheryl. World Bank: A Critical Analysis. Nova York: Monthly Review Press, 1982. 
PEREIRA, João M. M. Banco Mundial: dos Bastidores Aos 50 Anos de Bretton Woods (19421994). Topoi (Rio de Janeiro), v. 15, n. 29, 527-64, 2014.

PERES, Shimon. The New Middle East. Nova York: Henry Holt and Co., 1993.

PETRAS, James. NGOs: In the Service of Imperialism. Journal of Contemporary Asia, v. 29, n. 4, 429-440, 1999.

; VELTMEYER, Henry. Beyond Neoliberalism: A World to Win. Farnham: Ashgate, 2011.

; VELTMEYER, Henry. Globalization Unmasked: Imperialism in the 21st Century. Londres: Zed Books, 2001.

PUTNAM, Robert D. Bowling Alone: America's Declining Social Capital. Journal of Democracy, v. 6, n. 1, 65-78, 1995.

Making Democracy Work: Civic Traditions in Modern Italy. Princeton: Princeton University Press, 1993.

RAM, Uri. The Globalization of Israel: McWorld in Tel Aviv, Jihad in Jerusalem. Nova York: Routledge, 2008.

ROY, Sara. De-development Revisited: Palestinian Economy and Society Since Oslo. Journal of Palestine Studies, v.28, n.3, 64-82, 1999.

The Gaza Strip: a Case of Economic De-development. Journal of Palestine Studies, v.17, n.1, 56-88, 1987.

SAAD FILHO, A. Neoliberalismo: Uma análise marxista. Marx e o Marxismo, v. 3, n. 4, 2015.

SAID, Edward. Cultura e Política. São Paulo: Boitempo, 2012.

The End of the Peace Process: Oslo and After. Nova York: Vintage Books, 2003.

SAMARA, Adel. Globalization, the Palestinian Economy, and the "Peace Process". Journal of Palestine Studies, v. 29, n. 2, 20-34, 2000.

SAYIGH, Yusif A. The Palestinian Economy under Occupation: Dependency and Pauperization. Journal of Palestine Studies, v. 15, n. 4, 46-67, 1986.

SEIDEL, Timothy. Neoliberal Developments, National Consciousness and Political Economies of Resistance in Palestine. Interventions: International Journal of Postcolonial Studies, v.21, n.5, 727-746, 2019.

SHAFIR, Gershon; PELED, Yoav. Peace and Profits: the Globalization of Israeli Business and the Peace Process. In: (Eds.). The New Israel: Peacemaking and Liberalization. Boulder: Westview, 2000. 
SCHOULTZ, Lars. Politics, Economics, and US Participation in Multilateral Development Banks. International Organization, v. 36, n. 3, 537-574, 1982.

SCHULZ, Michael. Palestinian Civil Society. In: PETERS, Joel; NEWMAN, David. The Routledge Handbook on the Israeli-Palestinian Conflict. Abingdon: 2013.

SHWEIKI, Omar. Before and Beyond Neoliberalism: The Political Economy of National Liberation, the PLO and 'amal ijtima'i. In: TURNER, Mandy; SHWEIKI, Omar. Decolonizing Palestinian Political Economy: De-development and Beyond. Londres: Palgrave Macmillan, 2014.

SLATER, Jerome. What Went Wrong? The Collapse of the Israeli-Palestinian Peace Process. Political Science Quarterly, v.116, n.2, 171-199, 2001.

SPRINGER, Joanna. Assessing Donor-driven Reforms in the Palestinian Authority: Building the State or Sustaining Status Quo? Journal of Peacebuilding \& Development, v.10, n.2, 1$19,2015$.

SULLIVAN, Denis. NGOs in Palestine: Agents of Development and Foundation of Civil Society. Journal of Palestine Studies, v. 25, n. 3, 93-100, 1996.

TAGHDISI-RAD, Sahar. The Economic Strategies of Occupation: Confining Development and Buying-Off Peace. In: TURNER, Mandy; SHWEIKI, Omar. Decolonizing Palestinian Political Economy: De-development and Beyond. Londres: Palgrave Macmillan, 2014.

TARAKI, Lisa. Urban Modernity on the Periphery: A New Middle Class Reinvents the Palestinian City. Social Text, v. 26, n. 2 (95), 61-81, 2008.

TARTIR, Alaa. Contentious Economics in Occupied Palestine. In: GERGES, Fawaz. Contentious Politics in the Middle East: Popular Resistance and Marginalized Activism Beyond the Arab Uprisings. Nova York: Palgrave Macmillan, 2015

TARTIR, Alaa. Jericho Agro-Industrial Park: A Corridor for Peace of Perpetuation of Occupation? Ramallah: Bisan Center for Research and Development, 2012.

TOUSSAINT, Éric. The World Bank: a Critical Primer. Londres: Pluto Press, 2008.

; MILLET, Damien. Debt, the IMF, and the World Bank: sixty questions, sixty answers. Nova York: Monthly Review Press, 2010.

TURNER, Mandy. Completing the Circle: Peacebuilding as Colonial Practice in the Occupied Palestinian Territory. International Peacekeeping, v.19, n.4, 492-507, 2012.

The Political Economy of Western Aid in the Occupied Palestinian Territory Since 1993. In: ; SHWEIKI, Omar. Decolonizing Palestinian Political Economy: Dedevelopment and Beyond. Londres: Palgrave Macmillan, 2014. 
; SHWEIKI, Omar. Introduction: Decolonizing the Study of the Political Economy of the Palestinian People. In: Decolonizing Palestinian Political Economy:

De-development and Beyond. Londres: Palgrave Macmillan, 2014.

USAID. Tamkeen, Empowering Civil Society Organizations in the West Bank and Gaza Strip. Washington, D.C.: 2004.

VELTMEYER, Henry. Civil Society and Local Development. Interações, v. 9, n. 2, 229-243, 2008 .

VERACINI, Lorenzo. "Settler Colonialism”: Career of a Concept. The Journal of Imperial and Commonwealth History, v. 41, n. 2, 313-333, 2013.

WALLACE, Tina. NGO Dilemmas: Trojan Horses for Global Neoliberalism? In: PANITCH, Leo; LEYS, Colin (eds.). Socialist Register 2004: The New Imperial Challenge. Londres: The Merlin Press, 2003.

WEIZMAN, Eyal. Hollow Land: Israel's Architecture of Occupation. Londres: Verso, 2007.

WILLIAMS, David. The World Bank and Social Transformation in International Politics: Liberalism, Governance and Sovereignty. Nova York: Routledge, 2008. ; YOUNG, Tom. Governance, the World Bank and Liberal Theory. Political Studies, v. 42, n. 1, 84-100, 1994.

WILLIAMSON, John. What Washington means by policy reform. In: (ed.). Latin American Adjustment: How Much Has Happened. Washington, DC: Institute for International Economics, 1990.

WOLFE, Patrick. Settler colonialism and the elimination of the native. Journal of Genocide Research, v.8, n. 4, 387-409, 2006.

ZEIN, Rayya. Developing a Palestinian Resistance Economy through Agricultural Labor. Journal of Palestine Studies, v.46, n.3, 7-26, 2017. 
